A

\title{
Gleanings from Nature.
}


<smiles>CCCC1CCCCC1</smiles> 




I.

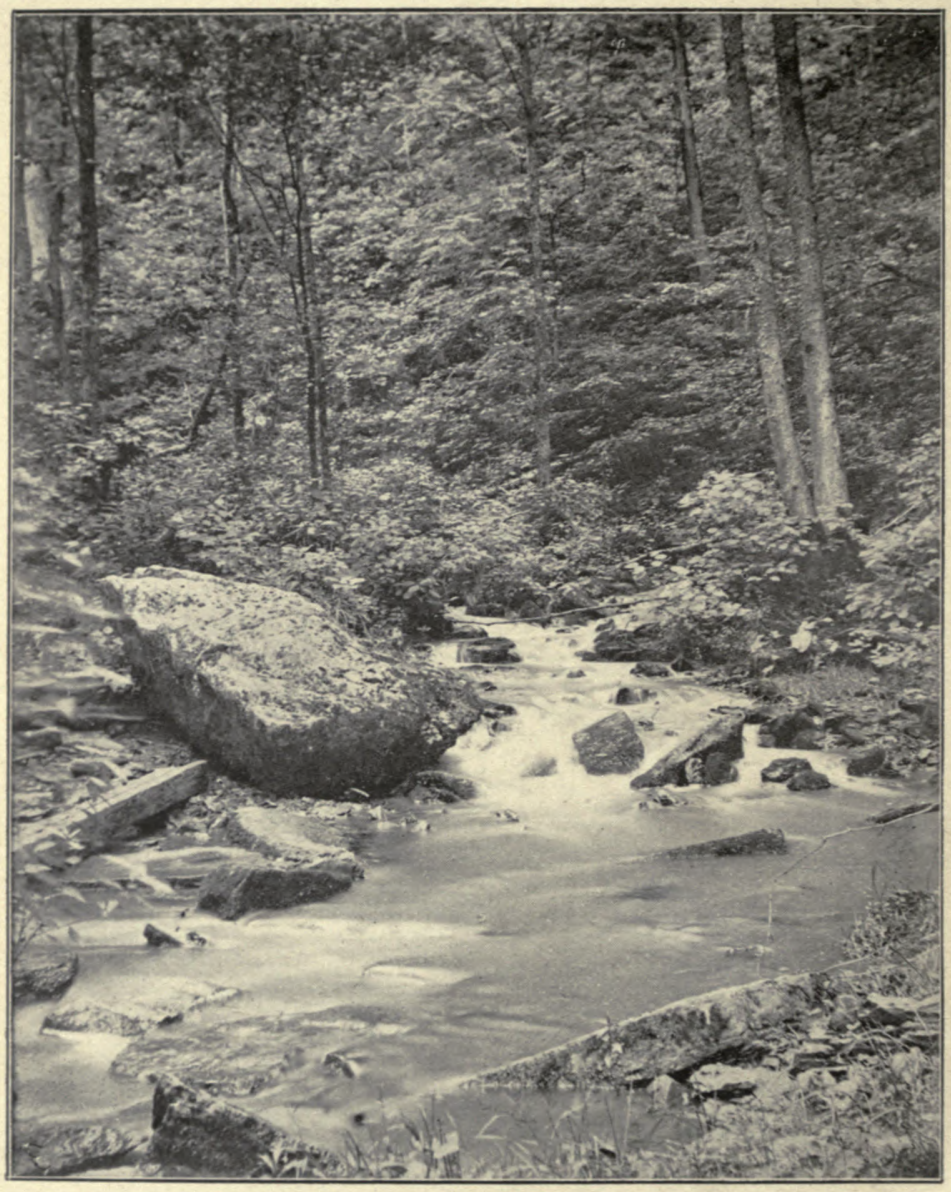

\section{The Brookside,}

Stream from Shawnee Cave, 100 yards below mouth of Cave. See the poem "A Rest by the Brookside;"' also page 121. 


\title{
GLEANINGS FROM NATURE
}

BY

\author{
W. S. BLATCHLEY
}

"I make it my business to extract from Nature whatever nutriment she can furnish me, though at the risk of endless iteration. I milk the earth and the sky . . . . I sift the sunbeams for the public good.",

- Thoreau.

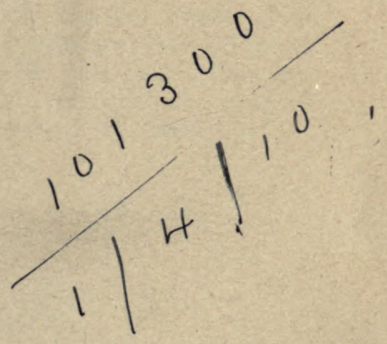

\author{
INDIANAPOLIS
}

The Nature Publishing Company 1899 . 


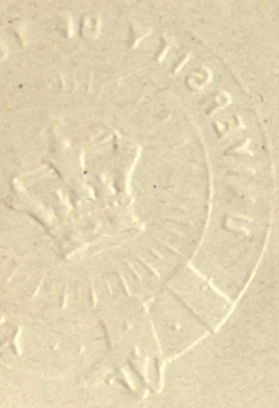

Copyright, 1899 ,

By W. S. BLATCHLEY

All rights reserved. 
"Nature never did betray

The heart that loved her; 'tis her privilege, Through all the years of this our life, to lead From joy to joy; for she can so inform The mind that is within us, so impress With quietness and beauty, and so feed With lofty thoughts, that neither evil tongues, Rash judgments, nor the sneers of selfish men, Nor greetings where no kindness is, nor all The dreary intercourse of daily life Shall e'er prevail against us, or disturb Our cheerful faith that all which we behold -Is full of blessing."

- Wordsworth.

"Whether it be the erested tit defying the chilliest blast of January; violets mantling the meadow banks in April; thrushes singing their farewell summer songs, or dull and dreary, dim December days it matters not-they never repeat themselves, or else I am daily a new ereature. Nor sight nor sound but has the freshness of novelty, and one rambler, at least, in his maturer years is still a boy at heart."-C. C. Abbott. 
To the 800,000 boys and girls on the farms of Indiana this little volume is inscribed, with the hope that it may create in some of them an interest in the many objects of Nature which surround them and so cause them to be less

"Blind to her beauties everywhere revealed,"

less prone to

"Tread the May-flower with regardless feet." 


\section{PREFACE.}

This volume deals with a few of the many natural objects which are found in all parts of Indiana. It is based upon studies made in the fields and woods of the Hoosier State during the past ten years. The aim has been to present, in language which all can understand, facts concerning some of the more common plants and animals which are our friends, our helpers and our neighbors-and which, like ourselves, are but a part and parcel of the Universe The only technieal terms used are the seientific names of some of the objects mentioned. These are printed in Italies and can be readily passed over by all to whom they are unintelligible.

The contents have, for the most part, appeared elsewhere as isolated articles, notably in the Terre Ilaute Gazette, the Indianapolis Sunday Journal, The Indiana Farmer and the Popular Science Monthly. For the present oceasion they liave, for the first time, been brought together, and have been carefully revised and enlarged.

The volume is sent forth with the hope that among the farmers of the future and the teachers of country schools it will, at least, have a welcome; for the anthor knows by experience, both on the farm and in the school room, that the possession of a better knowledge of nature by country youths is one of the crying needs 
of the hour. With such a knowledge generally diffused there would be less dissatisfaction with country life and fewer farmers' sons and daughters would flock to the cities, because, as a recent writer expresses it, "they wish to get rid of the prosy, stunting, isolated life on the farm." With a knowledge of some of nature's objects and a desire to ferret out for themselves some of her secrets, they would have something of which to talk and think besides erops, stock, work, neighborhood gossip and local polities, and the attractions of the city would seldom excel those to be found on the old homestead. 


\section{CONTENTS.}

PAGE.

A Rest by the Brookside.................... 8

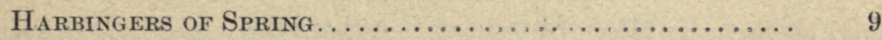

Two Fops Among the Fishes . . . . . . . . . . . . . . 19

SNAKES. . . . . . . . . . . .

A Feathered Midget and Its Nest $\ldots \ldots \ldots \ldots \ldots \ldots \ldots \ldots . \quad 75$

Mid-Summer Along the Old Canal .............. 82

THE IrON-WEED $\ldots \ldots \ldots \ldots \ldots \ldots \ldots \ldots \ldots \ldots \ldots \ldots \ldots \ldots \ldots$

Ten Indiana Caves and the Animals which Inhabit

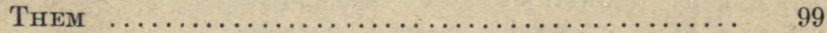

A Day in a Tamarack Swamp ................. 179

Mri-Autumn Along the Old Canal............... 189

Katydids and Their Kin $\ldots \ldots \ldots \ldots \ldots \ldots \ldots \ldots \ldots \ldots \ldots \ldots$

Weeds in General and Our Worst Weeds in Particular. 245

Twelve. Winter Birds. . . . . . . . . . . 253

How Plaants and Animals Spend the Winter .......... 313

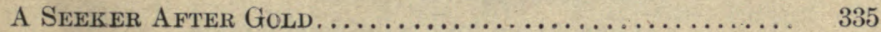




\section{A REST BY THE BROOKSIDE.}

Dreaming dreams of other days, Thinking thoughts of long ago, List'ning to the robin's lays And the eawing of the erow.

Ivy flowers beside me peep

Upward through the ether blue, Seeing stars which ever keep

Hidden-close from human view.

Bumble-bees around me drone, Butterflies beside me flit;

From the woods in cheery tone Comes the call of crested tit.

Swallows swiftly cleave the air Chasing insects on the wing; Scolding chats with saucy dare Make the copse and welkin ring.

Gurgling waters at my feet Quickly g'er their pebbly bed Leap and plunge; and onward meet Other streams by springlets fed.

Odors sweet on every breeze

Come to me from wild-wood flowers, While the blossoms from the trees Fall around in fragrant showers.

Happy moments thus I gaze

Heavenward; and younger grow, Dreaming dreams of other days, Thinking thoughts of long ago. 


\section{HARBINGERS OF SPRING.}

\section{SYMBOLS OF THE SEASON WHICH MAY BE SEEN IN WOODS AND FIELDS.}

When the month hand on the dial plate of the year points to March who, in the latitude of Indiana, is not daily expecting spring? What human being is not made glad when it finally arrives? Four months of biting winds and loar frosts; months in which the skies are almost daily overeast with dull dreary clouds; months of alternate rains and sleets and snows, are enongh to cause an intense longing for change in the human mind and to bring to it a glow of happiness when the first warm breezes blow up from the gulf and man ean say with reason-"Spring has come again." Then the dormant energies within us spring into new life. The doors and windows of our houses are thrown open wide. Smiles are seen on faces to which for the most part they are strangers. Wee tots of children run unattended up and down the streets and laugh and shout with joy. Matrons forget or cast aside set social rules and stop and chat in one another's dooryards. Fancied class distinctions, based on wealth or "blue blood," are forgotten and, for the time being, the members of the human family are more akin than at any other season of the year. All are enjoying a common blessing, for spring comes 
alike to rich and poor, to high and low, and all can revel in its presence.

To one accustomed to visit the woods and fields during March there appear many unerring signs of the coming spring-time which, to persons living in towns and cities, are often unnoticed and mnknowns The growth and flowering of certain wild plants; the awakening from their winter's sleep of reptiles, frogs and insects; the arrival of the first migrating birds, are to the careful observer sure harbingers of the close approach of the vernal season. If in March there occurs, as often happens, several successive days of warm weather more than a dozen kinds of wild plants will come into bloom. They are the fore-rumners or vanguard of the eight to nine hundred species of flowering plants which, in any county of Indiana, open their petals in successive rotation between March the first and mid-October.

Perhaps the earliest flowers of spring are those of the red or swamp maple, Acer rubrum Linn., a mediumsized tree which grows in abundance in damp lowland soil. This maple is often brought into the cities and palmed off on unsuspecting buyers of shade trees as the soft or white maple, Acer saccharimum Linn. Both of these trees differ in their habits of flowering from the rosk or sugar maple, Acer saccharum Marsh, in that their blossoms appear before their leaves. The flowers of the red maple are a handsome deep red in color and are arranged on very short stems in little clusters near the ends of the branches. They sometimes open in February, as they are formed in autumn, and, protected only by the enveloping bud scales, are 

II.

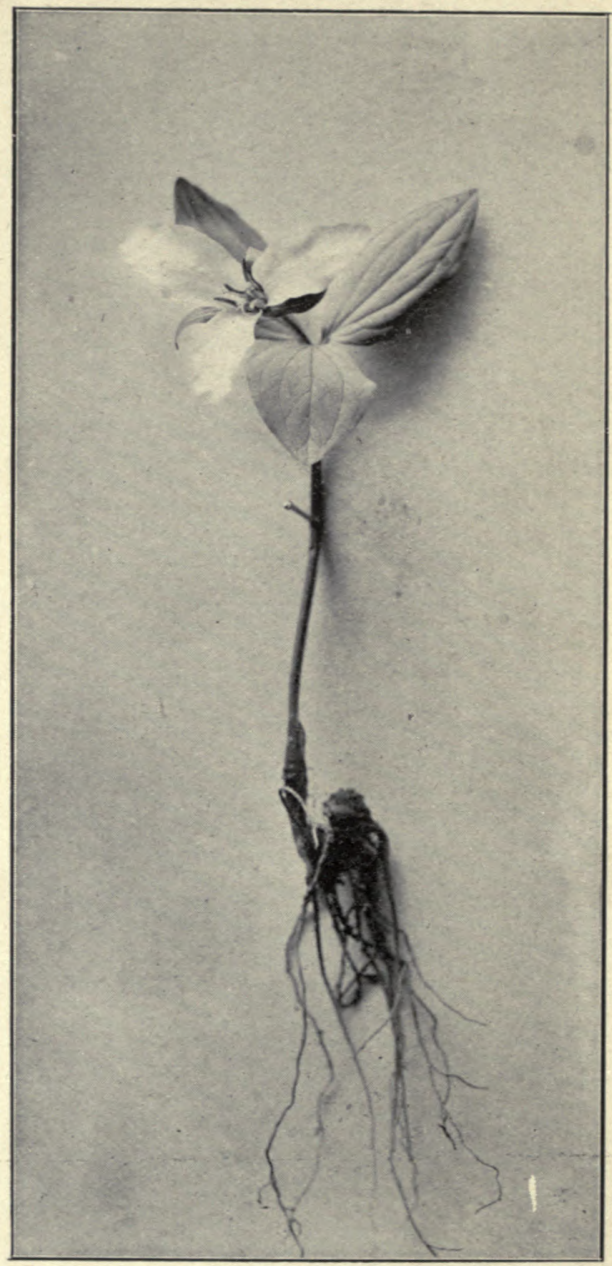

Snow Trillium.

Trillium nivale Riddell. 
ready to unfold as soon as the dormant sap of the parent tree is awakened by a genial south wind. The blossoms of the soft maple usually open a fortnight later than those of the red maple. They are yellowishgreen in color and are borne on longer stems.

Of the herbs which bloom in March there are two which, in central Indiana, vie with the red maple in produeing the first wild flowers of spring. They are the little snow trillium, Trillium nivale Riddell, and a species of Draba, or whitlow-grass, both inconspicuous plants and known for the most part only to botanists and close observers of nature. The snow trillium belongs to the Lily family and grows only at the base of rocky clifts or in erevices along the sides of ravines which have a sunny southern exposure. It seldom exceeds four inches in height, and, as its name, "trillium," indicates, has its parts in threes or multiples of three. Three dark green, ovate leaves grow in a whorl at the summit of the slender stem, and from their midst springs the stalk of the solitary flower. This is composed of three narrow green sepals, three oblong pure white petals, each about an inch in length, six yellow stamens, three styles and an ovary or seed pod containing three cells, each with a number of minute seeds. The plant springs from the ground and blooms in less than forty-eight hours, and where one day all is brown and sere, on the second day thereafter may be found an abundance of these little trilliums-true earth-born harbingers of the approaching springtime.

They may be found in blossom as early as March $2 d$, and are often in their prime by the tenth of 
the month. Hovering above them on both dates have been seen speeimens of Vanessa antiopa Linn., that handsome velvety-brown butterfly, called the mourning cloak, or Camberwell beanty. This is the most common of the five species of buttertlies which in Indiana pass the eold season in the perfect or winged stage. For four long months they remain securely hidden in erevices of rocks or logs. When called

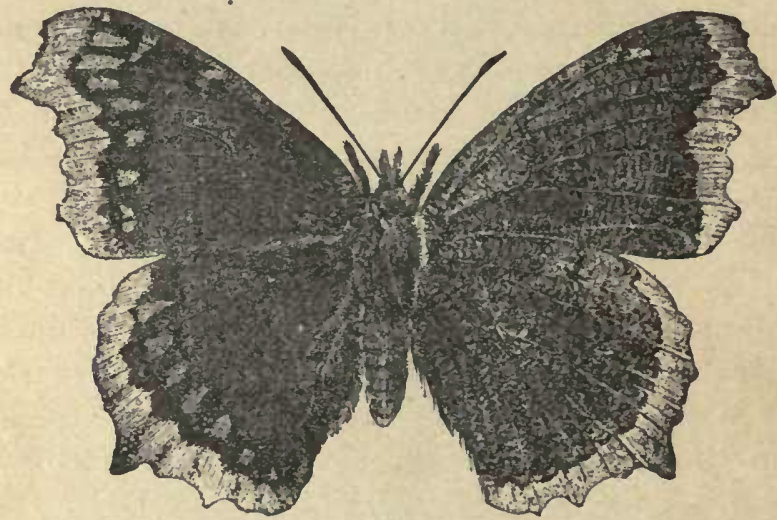

Fig. 1-Camberwell Beauty. (After IIarris.)

(The under side of wing is ehuwn on the right.)

forth by the warm spring breezes they find ready and waiting for them the snow trilliums with their store of honey, and, after their prolonged fast, they no doubt feast bountifully thereon. Thus is seen an example of that mutual interdependence existing everywhere among the various objects of nature, for never does an insect come forth until its food plant is ready; and, on the other hand, the plant seldom blooms but an insect appears ready to aid in its fertilization. 
Springing as it does from crevices and crannies in rocky clift's, reaching maturity and flowering as it does when all nature is destitute of bloom, the first snow trillium of spring carries ever with it a reminder of those lines of Tennyson:

"Flower in the crannied wall,

I pluck you out of the crannies;

Hold you here, root and all, in my hand, .

Little flower, but if I conld understand

What you are, root and all, and all in all,

I should know what God and man is."

Two species of Draba, or whitlow-grass, grow in central Indiana, viz., D. caroliniana Walt. and $D$. verna Linn. They are the smallest members of the Cruciferc, or Mustard family, and have their minute and hairy oblong leaves clustered in a rosette close to the ground. From the center of this rosette the leafless flowerstalk springs. The flowers are white, ten to fifteen in number, and have the parts in fours, except the stamens, which are six. The plants are found on dry, sandy hillsides in open fields. Rising less than three inches above the ground, they bloom on the first warm days of Mareh, and their seeds are ripened by mid-A pril. Their work is, therefore, over before that of many plants is begun. They sueceed in the struggle for existence by being first upon the scene of action. Drinking long and deep of the bright spring sunshine, they soon gire way to their competitors, but not before their life's duty - the perpetuation of their kind-lias been fulfilled.

On soft, springy banks one also finds in earliest spring the curiously formed fiower of the skunk cab- 
bage, Symplocarpus foctidus Nutt. It is, as it were, a leafless flower, barely rising out of the ground. At first the only semblance of a leaf is the enveloping spathe (like that of a calla lily), which is variously striped and spotted with purple and yellowish green, and has its top ineurved or bent over like a bird's beak to protect the enclosed flowers from any wintry blast which may arise. The true flowers are numerous, small and inconspicuous, and are borne on a thick, fleshy spadix or central axis within the spathe. The plant, after flowering, sends up a thick eluster of large ovate leaves, eighteen inches or more long, which surround the spathe. These leaves, when bruised, give off an odor resembling somewhat both that of a skunk and a mess of strong onions, or a kind of potpourri of the two, hence the common name of "skunk eabbage" by which the plant is known. Rich in pollen, the flowers of this plant furnish the first meal of spring to many a honey-bee; for the first warm day of March tempts these busy insects forth in numbers, and they find their way unerringly to the few flowers then in bloom.

Other plants there are, more striking and more beautiful than those mentioned, which soon open wide their petals to the sunshine of spring. Among the more common of them is the hepatica, or liverwort, Hepatica triloba Chaix.; the turkey pea, or "pepper and salt," Erigonia bulbosa Michx.; the spring beauty, Claytonia virginica Linn., and the cowslip, or marsh marigold, Caltha palustris Linn., but they are followers, not leaders in the floral army. When they blossom spring is here. But the flowers of the red maple, 
III.

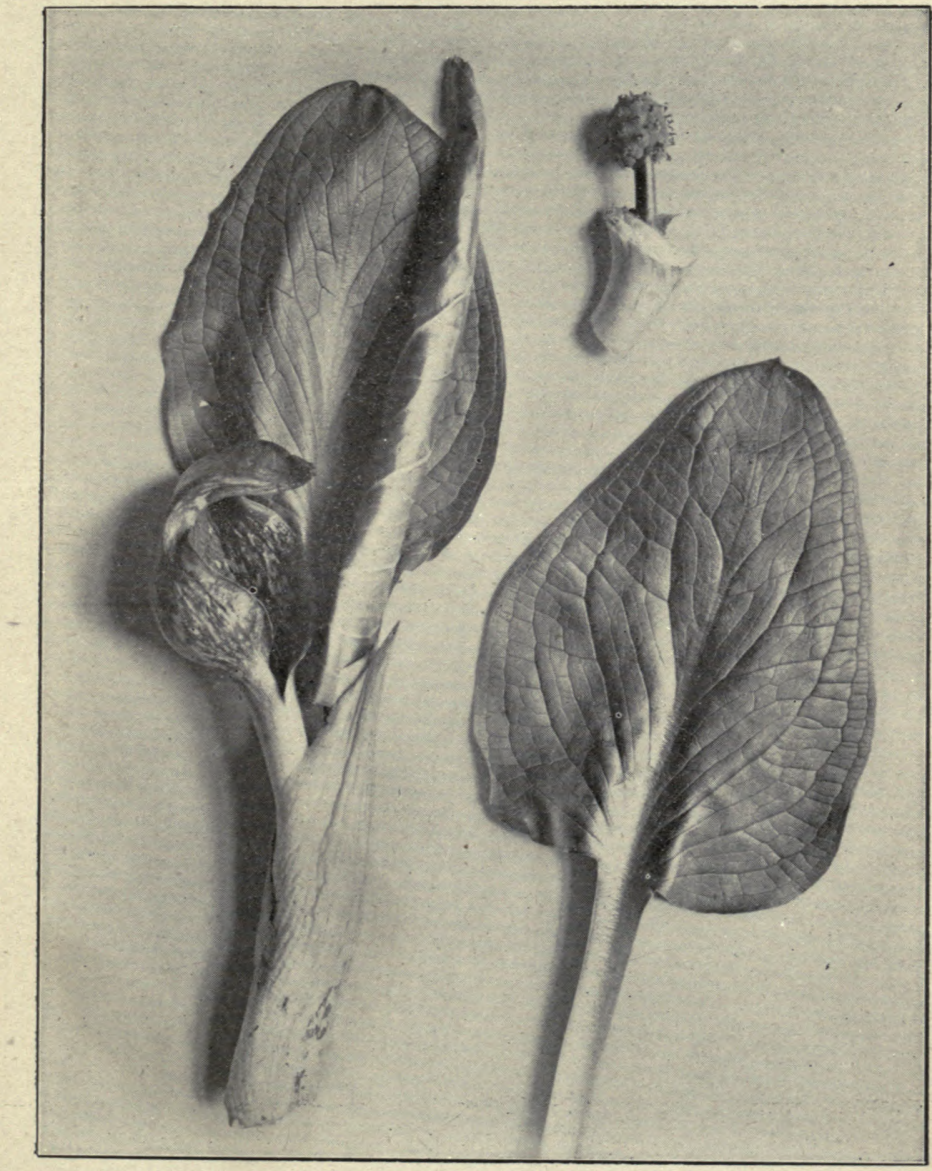

Skunk Cabbage.

Symplocarpus foetidus Nutt. 

snow trillium, whitlow-grass and skunk cabbage are the pioneers, the true harbingers, which heraid its approach.

A great awakening also takes place among the valied forms of animal life on the first warm days of March. Among insects the wherrymen, those longlegged water bugs which go skipping so easily aud rapidly over the surface of quiet pools, and the whirling beetles which in vast colonies go circling round and round on the water, are the first ones out. Fuzzy gnats,

"Old back-bent fellows,

In frugal frieze coat drest,"

come forth from their snug retreats beneath the bark of the beech and other logs, and, swarming in the air, calry on a sort of rhythmical courtship, flitting up and down in the same vertical plane in a dreamy, laneing sort of motion.

Beetles, of which, in any county in Indiana, fully three hundred kinds survive the cold season in the winged stage, clawl out from their winter hiding places and a-wooing go, buzzing and humming with extra energy to attract the notice of others of their kind. With the hibernating butterflies mentioned ahove, and numerous kinds of wild bees and flies, they frequent the fireshly cut stumps of the sugar maple, where they sip eagerly the sweet exuding sap.

Higlier in the scale of animal life omens of approaching spring may be seen in the movements of fishes. Thrilled with the inpulse of migration, many of the smaller species begin in February and March to ascend small streams and brooks, where, beneath 
the shelving banks and in the still waters of the deeper pools, they make their summer homes.

Frogs are among the best of weather prophets. They seem to know intuitively when the spring is full on its way. Long before the frost is wholly out of the ground the sluggish blood within their veins begins to tingle, and they greet the first dawn of spring with a mighty chorus-a blare of welcoming trumpets, as it were-in which the bull-frog furnishes the bass and the little cricket frog or "peeper," Acris gryllus crepitans Baird, the shrill whistling tenor. No sound of nature so loudly or so surely proclaims the advent of spring as this full symphony of frog music heard from some woodland pond.

The arrival of the first migrant birds is also a sure symbol of the coming spring. About 180 species pass northward through Indiana between February 15 and the 10th of May. In addition to these th least seventy-five kinds stop in the State and nest and rear their young. Wild geese and ducks are the first ones to be seen northward bound. Impelled by the pairing instincts, thousands of squads of these water birls start in February from the sumny lakes and lagoons of the South for the still cold and cheerless breeding grounds that extend from the Northern States through British America to the Aretic seas. The wild geese fly, as is well known, in a V-shaped line, with the apex forward. Their leader is a strong-winged gander, who keeps his place at the point of the $V$, and the clarion-toned "honk" with which he gires his orders is the first note of that coming bird chorus, which, starting from the gulf, will, with the south 
winds, soon sweep northward through field and forest in an unbroken wave to the very pole itself.

In the close wake of the larger water fowl come the snipe and the woodcock, Philohela minor (Gmel.) - the latter arriving so early that a full set of its eggs was once found by the writer on the 28th of March.

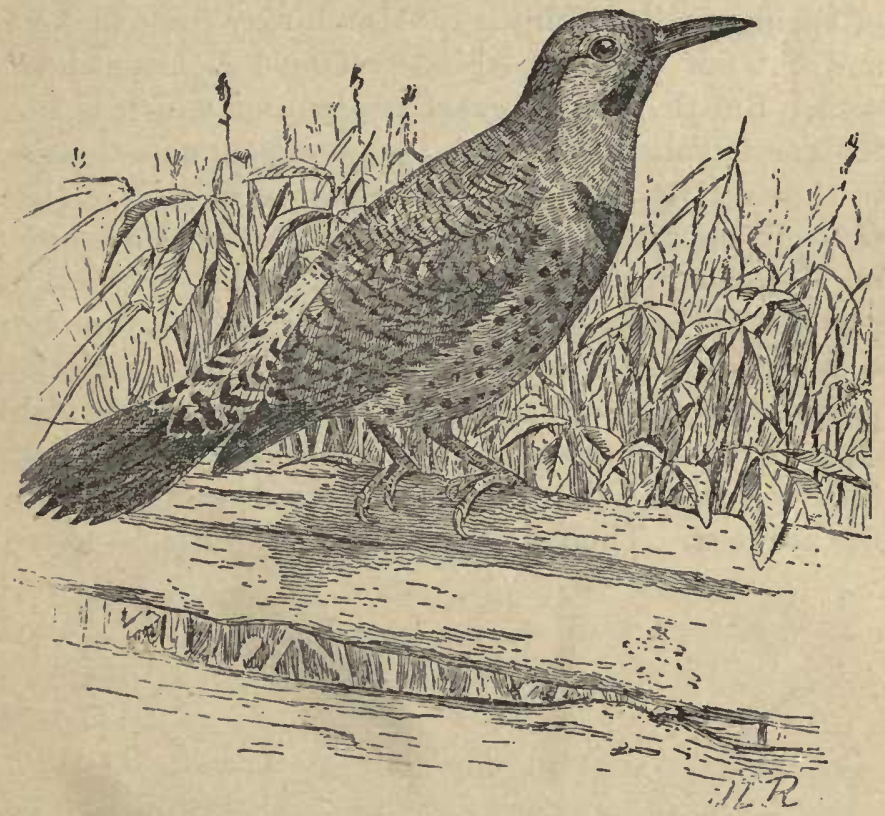

Fig. 2-The Flicker or Yellow-hammer. (After Beal.)

Anong the land birds two of the first to arrive are the flicker, or yellow-hammer, Colaptes auratus (Limn.), and the red-shouldered blackbird, Agelaius phoniceus (Linn.); and the prolonged "wick-a-wick-a-wick" of the former and the clear, ringing "puck-e-e-eet" of 
the latter are familiar greetings given the rambler in open woods in early March. These birds are soon followed by the handsome but little-known fox sparrow, Passerella iliaca (Merr.), whose rich strains, heard from the underbrush along the streams, form the first real song of spring.

Some years winter lingers unusually long in the lap of spring, and two-thirds of March may come and go and but few of the harbingers above mentioned be seen. But that day of great awakening, which in the temperate zone comes each year to all animate things, in time arrives. We should expect it, should rejoice to see it, should give it hearty greeting. In the words of Thoreau: "Measure your health by your sympathy with morning and spring. If there is no response in you to the awakening of nature; if the prospect of an early morning walk does not banish sleep; if the warble of the first bluebird does not thrill you, know that the morning and spring of your life are past. Thus may you feel your pulse." 


\section{TWO FOPS AMONG THE FISHES.}

\section{I.-THE RAINBOW DARTER. \\ "Little fishy in the brook."}

Not the one "daddy eanght with a hook," but another, too small for the hook, too small for the fryingpan, too small for aught else but beanty, and gracefulness of form; and yet not the young of a larger fish, but full grown of himself. In every brook in the State he may be found, yea, even in the rill, no more than a foot in width, which leads a way from the old spring-house on the hillside. You will not find him swimming about like the minnows in the still deep water of the stream, but where the clear cold water is rushing rapidly over the stones of a ripple he makes his home. There he rests quietly on the bottom, waiting patiently for his food, the larve or young of gnats, mosquitoes and other such insects, to float by.

If you attempt to catch him, or your shadow suddenly frightens him, with a sweep of his broad peetoral or breast fins, he moves quicker than a flash a few feet farther "p the stream and then as suddenly comes to a stop, and resumes his quiet "thoughtful" attitucle. If you persist in your attempt to capture him he will dart under a small stone or submerged leaf, where, like the foolish ostrich which when pursued 
hides her head under her wing, no longer seeing you, he thinks himself secure.

On aceount of the shape of his body as well as on account of his rapid movements he has received the surname "darter." Belonging to the group which bear this surname, there are, in the eastern half of the United States, about 47 species or kinds, the largest of which, when full grown, measures only about six inches in length, while the smallest species never reaches a length of more than an inch and a half. They all have the same habits, and at least 29 kinds of them are found in Indiana; but the one of which I an writing, Etheostoma coruleum Storer, is much the

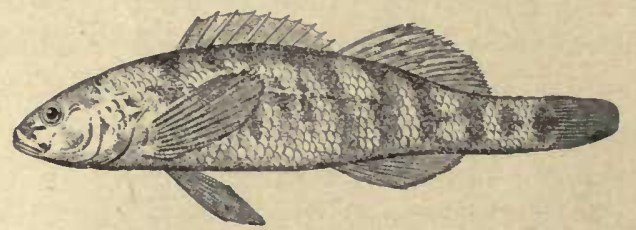

Fig. 3-Rainbow Darter.

more common. Hie is from two to two and a half inches in length, and, like the other members of his family, has two fins on his back; "dorsal" fins they are ealled by naturalists, the front one of which contains 10 short spines. During eight months of the year, the males and females dress alike in a suit of brownish olive which is striped on the sides with 10 or 12 narrow, black eross-bars, and more or less blotched on the back with darker spots. But on the first warm days of spring when the breezes blow up from the gulf, awakening the gypsy in our blood, the little male fish feels, too, their influence, and in him there 
arises an irresistible desire to "a courting go." Like most other beings of his sex he thinks his every-day suit too plain for the important business before him. It will, in his opinion, ne'er eatch the eye of his lady love. So he dons one of gaudy colors and from it takes his name-the rainbow darter-for in it he is best known, as it not only attracts the attention of his chosen one, but often also that of the wandering naturalist who happens along the stream.

The blackish bars of other seasons are changed to indigo blue, while the space between them assumes a hue of the brightest orange. The fins are broadly edged with blue and have the bases orange, or orange and scarlet, while the cheeks assume the blue and the breast becomes an orange. Clad in this suit he ventures forth on his mission, and if suceessful, as he almost always is, the two construct a nest of tiny stones in whieh the eggs of the mother fish are laid and watched over with jealous eare by both parents until in time there issue forth sons destined some day to wear a coat of many colors, and "darters" to be attracted by those coats, as was their mother by the one their father wore.

Although so abundant and so brilliant in the springtime, the rainbow darter is known to few but naturalists. The fishes in which the average eountry boy is interested, are the larger ones-such as the goggleeye, the sucker, ehub and sunfish - those which, when caught, will fill up the string and tickle the palate.

But there are, let us hope, among our farmers' sons and daughters, some who are learning to take an interest in the objects of nature which are beautiful, 
as well as in those which are usefiul. 'T'o them I will say, if you wish to see something really pretty, make a seine from an old coffee sack or a piece of miosquito netting, and any day in spring drag two or three ripples of the branch which flows through the wood's pasture, and ten ehances to one you will get some "rainbows." By placing them in a fruit jar threefourths full of clear, cold water, and renewing the water every few hours, they ean be kept for several lays; but they can not bear the confinement long, accustomed as they are to the free running stream from which they were taken.

By taking the rainbow as the type of the darter and studying closely its habits, both in captivity and in the streams, much can be learned about a group which, in the words of Dr. S. A. Forbes, "are the mountaineers among fishes. Forced from the populous and fertile valleys of the river beds and lake bottoms, they have taken refinge from their enemies in the roeky highlands where the free waters play in ceaseless tor'rents, and there they have wrested from stubborn nature a meager living. Although diminished in size by their continual struggle with the elements, they have developed an activity and hardihood, a vigor of life and a glow of high color almost "unknown among the easier livers of the lower lands."

\section{II.-THE LONG-EARED SUNFISH.}

Among the most brightly colored of all the fresh water members of the finny tribe is the long-eared sunfish, Lepomis megalotis (Raf.). When full glown 
its length is about eight inches and the breadth onehalf as much. The eolor is then a brilliant blue and orange, the former predominating above; the orange on the sides in spots, the blue in wavy, vertical streaks. The eheeks are orange with bright blue stripes; the fins with the membranes orange and the rays blue. Extending back from the hind margin of each cheek is a conspicuous blackish membrane termed an "carflap," which in this species is longer than in any other

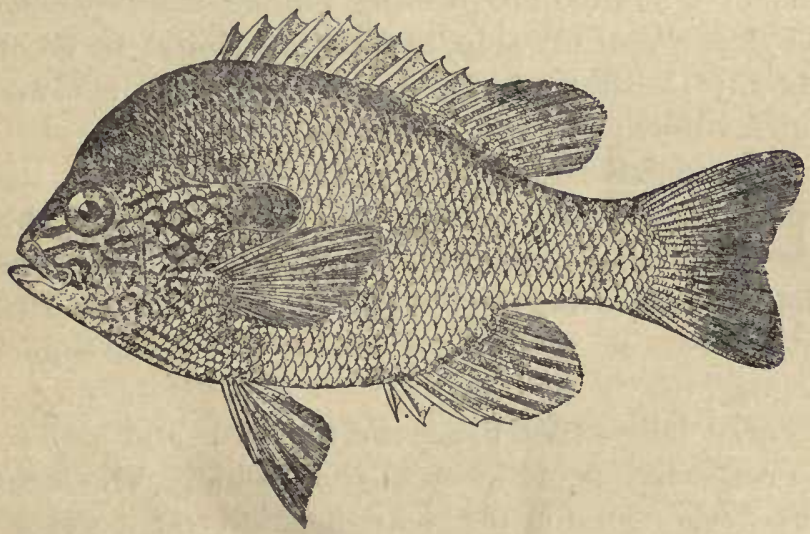

Fig. 4-Long-eared Sunfish. (One-half natural size.)

of the sunfish family, whence the specifie name, megalotis, from two Greek words meaning "great" and "ear".

Within the placid pools of the brooks and larger streams of the State this sunfish has its favorite haunts. Mid-summer is the time when its habits can be best observed. On a recent August morn I sat for an hour or longer on the banks of a stream, which flows 
throngh a wooded blue-grass pasture, and watehed the denizens of its waters. A peaceful ealm existed, the water being without a ripple and with searee the semblance of a flow-the air without the shadow of a breeze. Dragon flies lazily winged their way across the pool, now resting daintily upon a blade of sedge or swamp grass, now dipping the tips of their abdomens beneath the surface of the water while depositing their eggs. The only sounds of nature were the buzz of a bumble-bee feeding among the flowers of the Brunclla at my side, and an oceasional drawl of a dog-day locust from the branches of the sycamore which threw a grateful shade about me.

The sunfish "hung motionless" in the water, their heads towards me, holding their position only by a slow flapping of their dorsal and peetoral fins. Their nesting time over, their season's labor ended, it was with them, as with many other beings, a time of languor.

These long-eared fishes are the lords and ladies of the respective pools wherein they abide. When they move other smaller fry clear the way. If a worm or gnat, falling upon the surface, tempts them, it is theirs. $A$ leaf falls near them and is seemingly unnoticed-a fly, and how quiekly their dormant energy is put into motion. With a dart and a gulp the insect is swallowed and a new stage of waiting expectancy is ushered in.

How admirably fitted their form for cleaving the water! They often seem to glide rather than propel themselves through its depths. Again, how swiftly the eaudal fin moves when with straight unerring 
motion they dart upon their prey. At times one turis his body sideways and, with a slow, upward-gliding motion, moves toward some object on the surface which is doubtfully "good to eat." He even takes it into his mouth and then, not having faith inwhis power to properly digest it, ejects it with force, and turning quickly darts back to the friendly shadow of a bowlder beneath whose sides he has, in time of threatened danger, a safe retreat.

I throw a grasshopper into the pool. Like a flash six of the sunfish are after it. One reaches it a tenth of a second in advance of the others, and with a lightning-like gulp, which disturbs the serenity of the surface of the pool, swallows the kicking prey. The energy of the sun's heat and light, stored in grass, transmitted to move muscles in gigantic leaps, will, in a short time, wag a caudal fin and propel the owner through these watery depths.

Years are thus doubtless spent by these long-eared sunfish in a dreamy sort of existence, their energies quickened by the vernal season and growing duller on the approach of winter. Excepting the times when they are tempted by a wriggling worm on some boy's hook, theirs is a life exempt from danger. A kingfisher glancing down from his pereh on the bent sycamore limb may, at times, discem them and lessen their ranks; but, nethinks, the chub minnows, with fewer spines in their dorsal fins, are more agreeable to the kingfisher's palate. With all the tints of the rainbow gleaming from their sides they move to and fro, the brilliant rulers of these quiet pools.

The king or monareh of those noted was most 
gorgeously arrayed. In addition to the hues above described, a streak of emerald bordered his dorsal and caudal fins and was bent around the edge of his upper lip-a green mustache, as it were. By tolling them with occasional bits of food I drew him and his retinue close into shore. There, for some time they rested, watching eagerly for additional morsels. As I was leaving I plucked from my sleeve an ant and threw it towards them. A dart, a gurgle, a gulp-the leader had leaped half his length from the water, and the ant was forever gone. The ripples receded and finally disappeared, and the last scene in this tragedy of nature was at an end. 


\section{SNAKES.}

\section{I.-SNAKES IN GENERAL.}

Snake season will soon be here once more. Even now the editors of the country newspapers are poring over the musty pages of some aneient natural history or seeking :midst those still more inusty convolutions of their brains in which their natural history facts are stored, to find a basis for one of the annual snake lies, which, like the dandelions, are sure to appear when spring approacheth. For next to "fish stories," newspaper "snake lies" are sure to be appreciated and believed in by a certain class of readers. True it is that the editor or reporter does not always clothe the lie in all its after habiliments, but each reader on repeating it to his neighbor adds a garment, until out of "whole cloth," as it were, the lie becomes a finished product and is repeated so often that it is finally believed as gospel truth.

Examples of such snake lies are the "hoop snake" which, taking its tail in its mouth, rolls rapidly on-

\section{Some Common} ward until it strikes a tree into which Snake Lies. it darts its tail, poisoning the sap and causing the death of the tree; the "glass snake" which, when approached, breaks into a score of pieces, and when mobserved quickly joins

*Terre Haute Gazette, A pril 2d, 1892. 
them again in the proper order and moves rapidly away; the black snake" eight feet long and as thick as your wrist"; the spreading viper "the most poisonous of all snakes," and of which one writer has said: "When approached it becomes flat, appears of different colors, and opens its mouth hissing. Great care must be taken not to enter the atmosphere which surrounds it. It decomposes the air, which, imprudently inhaled, produces languor, the person wastes away, the lungs are affected and in the course of four months he dies of consumption." That the last story, or something akin to it, is commonly believed, is proven by the fact that a prominent eitizen once told the writer that the breath of the spreading viper had caused him a two weeks' spell of sickness.

Many other "snake lies" the writer has heard, and, to tell the truth, believed in, until he came to get his knowledge first hand by studying the ereatures in their chosen haunts, when he saw how unworthy of belief many of these stories are: For example, taking the four above noted, and tracing each back to its source, we find that the common honse or milk snake, Ophibolus doliatus triangulus (Boie), while crawling, occasionally raises the middle of its body above the ground, as does the measurng or loop worm, and this fact gave rise to the story of the "hoop suake."

The "glass snake" is a lizard, Ophisaurus ventralis (L.), which, like other reptiles of that class, chooses at times when eaptured by the tail, to drop that portion of the body rather than remain a captive; but, as to coupling it on again, no person with any regard for the truth will swear he ever saw it done. 
No black snake over six feet and a few inches long has as yet been recorded in any scientific work. Twice within the past five years black snakes, kept in - captivity by the writer, have escaped, and were killed shortly afterwards near the center of the city. On both occasions the daily papers noted the killing but in each instance, if we take the newspaper measurement as correct, the snake had increased in length nearly a foot and a half during the twenty-four hours intervening between its escape and death.

As for the spreading viper, although it is true that it flattens its body and hisses when approached, yet its bite is perfectly harmless as it is destitute of poison fangs; and its colors are as unchangeable and its breath as unproductive of disease as are those of the leading gander of the barnyard flock which hisses when we approach his domain.

The best way to show the falsity of many of the beliefs concerning the harmfulness of snakes is to record a few facts coneerning the life history and habits of some of the more common species inhabiting Indiana. To begin, we will say that the usual belief that allesnakes are hatched from eggs is an erroneous one. Many species, examples of which are the copperhead, rattle-snake and three or four kinds of garter-snakes, bring forth their young alive. The young of snakes, except in size and sometimes in color, resemble their parents and do not undergo a change or metamorphosis, as do the tadpoles, or young of frogs and salamanders. Those snakes which lay eggs deposit them in the earth, sand, or the humus of rotten logs, where they are left to be hatched by the 
moist heat of their surroundings. These eggs are yellowish white in eolor, and vary in size from $\frac{1}{2} \mathrm{x}_{4}^{3}$ inches up to that of a pigeon's egg. They The Young are usually elliptical in form and have
of Snakes. a tough leathery skin. The number varies with the different species, some laying as many as twenty at a time. The mother snake sometimes remains in the vicinity of the eggs until they are hatched. The young then accompany the mother for a time, and of certain speeies, it has been affirmed, that in time of danger the young escape down the throat of the mother. Of most snakes, however, the young, when hatched or born, are left to shift for themselves, and possibly not more than one in a hundred lives to be a year old, as they have many enemies among the other animals-even among their own kin.

If a snake be carefully examined many interesting faets concerning the structure of its body may be noted. Their long, slender, limbless forms are, on the upper side, covered with scales which overlap one another like the shingles on a roof. On the under side these scales are much larger and form a series of broad, overlapping plates which extend the full length of the hody. These are technically known as vential plates or scutes.

Many a person has, perhaps, wondered how an animal without limbs, wings or fins can move so rapidly and gracefully as does a snake. The Structure By examining carefully a snake's skel-
of a Snake. eton and noting its relation to these ventral plates one can easily understand how the movement is made. The skeleton consists merely of the skull, spinal column and ribs. 
A pair of ribs extend downward from each vertebra of the spinal column, and to the lower ends of these ribs a ventral plate is attached by muscles. The snake then moves its ribs much as a millipede or "thousandlegged worm" moves its legs. The edges of a few of the ventral plates eatch against any roughness on the surface over which the snake is crawling, and hold that part of the body while another part advances. Put a snake outo a smooth surface as ice or a polished floor and it will move with much difficulty, if at all. IIence, we see, that a snake in reality walks with its riis.

The skin of a snake, scales, plates and everything, is shed several times a year. The first moult of the season usually takes place in the
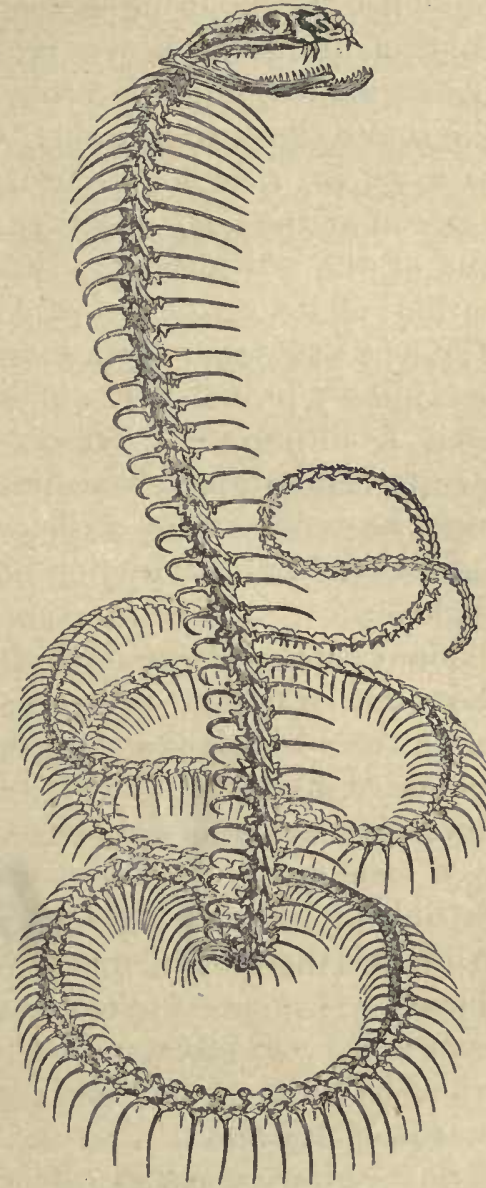

Fig. :-Skeleton of a Snake. early spring, soon after the snake regains activity; 
a second occurs in June or July, and often a third in late summer or early antumn. One ean always tell when the moulting is about to take place by the color of the snake becoming very dull and an apparent whitish film appearing over the eyes In fict the snake seems to be going blind. The skin is shed as a whole, a rent appearing on the back, and first one end of the body and then the other being pulled out of the old garment. Even the cornea, or outer surface of the eye, and the skin of the lips are shed. The new skin is very bright and showy and the snake is evidently proud of it, appearing much more lively after monlting than before. New skins are constantly being formed beneath old ones and the reptile must keep one or two on hauds for an emergeney, as the writer has by dissection found three skins on one snake.

Many persons are needles:ly frightened when a snake darts out its tongue at then. The tongue is nothing but a thread-like muscle forked or divided for about one-third of its length. It lies on the midllle of the lower jaw and when at rest is eovered with a sheathlike membrane. Soft and elastic in structure, it is capable of being darted back and forth very rapidly. Although the tongue is perfectly hammess the snake, during past generations, seens to have learned that man and some other animals are afraid of it, and so, when irritated or molested, darts it in and out as a means of defense.

Snakes have no onter ears and no eyelids. To the latter fact is due the "cold stony glare of the serpent." Their jaw bones or mandibles are held together only 
by ligaments. This enables them to open the month very widely and to swallow animals much larger in diameter than themselves. They swallow all food whole withont mastication. In this they are aided by a copious flow of saliva which lubricates their prey, and eauses it to pass into the stomach more readily. Whenever they cateh a frog or other animal with limbs they manipulate it in such a manner as to enable them to swallow it head first. The limbs of the victim are thus pressed close to its body and the act of swallowing is but little hindered by their presenee.

Snakes are "cold blooded" animals; i. e., their bodily temperature is not constant like that of man, but varies with the temperature of the air which they breathe. On that account they become sluggish in late autumn, and, seeking a crevice in a rock or hole in the ground, they crawl into it and remain throughout the winter, eating nothing and moving not. Large numbers sometimes find their way to the same place

Hibernation of Snakes. and are often found eoiled and twisted together, thus giving rise to the many stories of so-called "suake dens." If the winter be an open one this hibernation, as it is called, is often interrupted and the animal comes forth from its retreat on some warm sumy day, thinking, no doubt, that spring has come again. During an excessive thaw the high water often finds its way into the snake's resting place and many are doubtless drowned while still torpid. Others escape and make their way to a higher and drier spot. Thus on Jannary 11,1890 , the writer found two species of garter 
snakes beneath some fine driftwood, near the margin of the overfiowed bottoms, north of Terre Hante. They had been driven forth from their winter retreat by the high waters and had taken temporary refuge beneath the drift.

On the first warm days of spring the sluggish blood in the veins of the hibernating snakes begins to flow more rapidly. Their bodily temperature gradually rises. Demand for food and an irresistible desire to mingle with others of their kind soon eause them to move out and streteh their bodies in the warm sunshine and in a few weeks their summer haunts know them as of yore.

The food of suakes is often the subject of much eonjecture among those persons who know the reptiles

Food of Snakes. only from an occasional chance meeting with them. For example, sone people aceept literally the biblical statement that they live upon dust, as the following inquiry received by the writer will attest: "Is it necessary" that snakes have plenty of earth (or dust) to eat to keep them alive? A friend of mine thinks that snakes live largely on dust (or earth) but I do not think so. Which is right? The dispute came up in our young men's bible class on the reading of the following verse: "And the Lord God said unto the serpent, because thou hast done this, thou art cursed above all cattle, and above every beast of the field. Upon thy belly shalt thou go, and dust shalt thou eat all the days of thy life :' Genesis, iii.-14."

Like other cold blooded animals snakes can fast for a long time. In fact, in eaptivity, they have been 
known to eat nothing for over a year although food was frequently offered them. They need water, however, especially as their moulting time draws near. What they eat depends to a great extent upon the speeies, some preferring one kind of food, some another. Like most men they are not fond of "cold victuals" but prefer to capture their prey alive. Frogs, tadpoles, small fish, young birds, field mice, rats and esperially insects and their larva, are their favorite foods. When they take a notion to eat they believe in "gittin' a plenty while they're gittin,", provided they have a chance. Thus, no less than seven large leopard frogs, besides a mass of other material, were once found in the stomach of a common water snake, Tropidonotis sipedon (L.), which was dissected by the writer on account of its aldermanic appearance.

Many snakes have also eannibalistic tendencies, so that the aceompanying illustrated "suake lie" has that much for a basis.

Two instanees of a snake's cannibalism have come to the personal notice of the writer. Once, while engaged in traeing a geologieal outerop in the wilds of Arkansas, he saw the top of a small bush shaking gently to and fro. Investigating the eause of the movenent he found a half grown black suake with a specimen of the summer green snake, Cyclophis restivus (I.), partially swallowed. The green snake had been eaught by the head and while endeavoring to escape had wrapped its tail in a double coil about the bush. The black snake had to snspend operations when he had swallowed up to the bush, and was evidently awaiting the digestion of the part within his 
body when discovered. This, no doubt, sounds like one of the "snake lies" referred to above, but the-
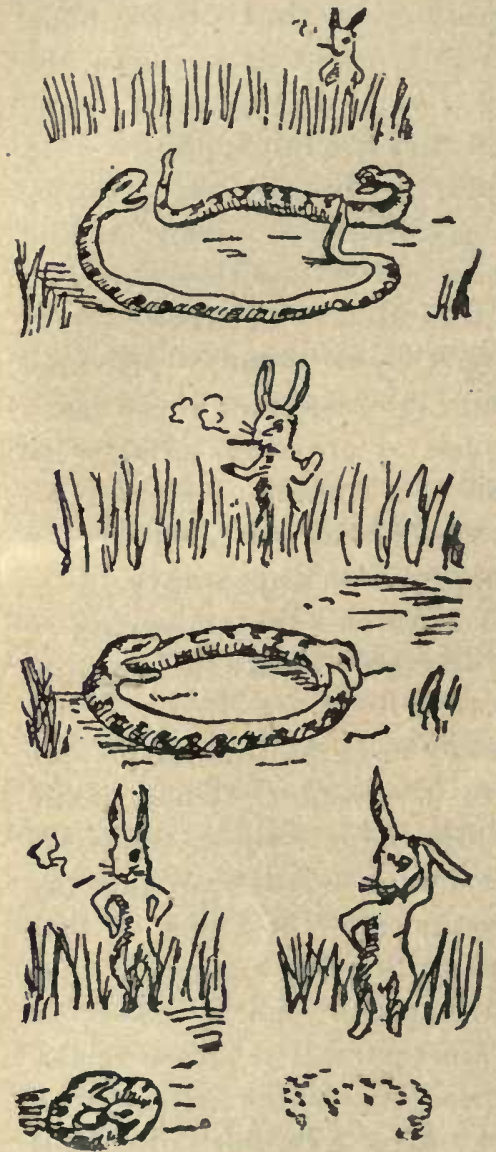

Fig.6-An Illustrated " Snake Lie." green snake, with the mark of the black one's teeth upon its body, was preserved in alcoliol, and is yet in the writer's collection.

In the second instance a pupil brought in a king suake, Ophibolus getulus sayi (Holbrook), 12 inches in length, which had protruding from its month four inches of the tail of a common garter snake, Eutainia sirtalis (L.). The latter was 13 inches in length and the front nine inches of its boly was within that of its captor. When taken the king snake tried to disgorge its prey but his gartership was too deeply lodged. The two were quickly consigned to a bottle of alcohol there to serve as a foreible illustration of the fact that the king snake is in reality both a king and a camnibal among its kind, 
On account of their liking for field mice, insects and other vermin, each black snake on a farm is worth at least five dollars, and each garter snake one dollar, every year of its existence. In other words the damage which the mice, insects, etc., eaten by the snakes, would do, would amount to more than the sums mentioned. Both black and garter snakes are perfectly harmless, and yet as soon as one is seen eight farm boys out of ten, and almost as large a proportion of the farmers themselves, will procure a long club or a stone and mash the poor, defenseless snake's head to a jelly. Then if the suake be a large one, the exploit is bragged of all over the neighborhood. In the writer's opinion such an act is a cold blooded murder and the deed of a coward. As well might a giant brag of killing a dwarf as a man of killing a harmless and defenseless suake.

But few of the harmless snakes use their teeth as their chief means of defense. It is only when irritated or suddenly attacked that they will strike at a person, and the pain caused by their bite is no more severe than that produced by the bite of a nouse or the prick of a pin; the most serious result of the bite being usually the fright which timid persons sustain. Once in a great while, however, the bite of a harmless snake may cause a swelling of the organ bitten, and, one time in a thonsand, may even cause death. This is due, however, not to any venom injected into the wound, but to a kind of blood poisoning brought abont by some substance adhering to the teeth of the reptile, the victim being in a weakened physical condition and therefore very susceptible to such a result. 
The bite of a mosquito has been known to prove fatal under similar conditions.

Their other means of defense and protection against their enemies are, however, numerous and interesting to note. Almost all of them dart out

Methods of

Defense Used

by Snakes.

the tongue when approached, seeking thus to terrify into retreat the aggressor. In this they are often successful, especially with mankind. Most other animals seem to know that the tongue is harmless and pay no attention to it. Some snakes, when molested, enlarge the body and so render themselves as formidable in appearance as possible. They do this, either by inflating with air to their fullest capacity, the long slender lungs, as does the spreading viper, whence the name "puffing adder" sometimes applied to it; or by flattening the body, by spreading out the ribs and then raising the scales, as does the common garter snake and the spreading viper. Certain species, when disturbed, force the air from their lungs with a hissing sound. This noise, no doubt, serves to frighten some of their enemies, but the expelled air is, in itself, wholly harmless.

A number of the larger snakes, among them the black snake, pilot snake, house snake and spreading viper, when alarmed, often try to imitate the peculiar rattle of the rattle-snake by vibrating the tail with great rapidity. If the vibrating tail happens to strike against some dead leaves the sound is very similar to that produced by the rattle-snake, and the writer, on hearing it, has frequently leaped back from a harnless snake thinking that he had been deceived as to the reptile before him. 
No snake can, like the tree frog and the chameleon, change its colors to suit its surroundings; but many, during the summer time, frequent such places as accord most closely with their own hues. In this manner they not only lessen the chances of discovery by their enemies, but also increase their opportunities of obtaining food, as other animals, not pereeiving them, will approach within striking distance. Thus, green snakes climb bushes and recline for hours on the slender branches among the leaves, waiting for insects and small birds to approach; and several of the smaller brown suakes remain for the most time among the dead leaves and grass, about logs and the roots of trees.

A few species, as the common garter snake and the spotted water snake, excrete a disgusting odor when handled and this no doubt serves to protect them from many enemies. Still others, when disturbed in their dreams on a bright spring morning, feign death or "play possum" as it is popularly put, remaining rigid and motionless as long as one stays in their vicinity, but seeking safety in flight as soon as they think themselves unnoticed. The above are a few of the many ways in which these reptiles seek to exercise their natural right of defending themselves. No one of the methods noticed is in the least degree harmful to man, and even if so, it must be remembered that whatever a non-venomous snake does is in self defense, as it is never the attacking party. 


\section{II.-THE SNAKES OF INDIANA IN PARTICULAR.}

About sixty species of snakes inhabit that portion of the United States east of the Mississippi River. Of these the bite of but six is poisonous. 'Twentynine species and ten varieties are known to oceur within the State of Indiana. Of these, four are poisonous, all the rest being perfeetly harmless as far as the bite is concerned.

\section{POISONOUS SNAKES.}

With one exception the poisonous snakes of the State may be known from the harmless ones by the following eharacters. The head is broader than the body, flat and triangular, and has a deep pit on each side between the eye and the nostril, whence the name "Pit Vipers" which is sometimes given to the group. There are no solid teeth in the upper jaw, but on each side in front is a hollow poison fang which ean be depressed against the roof of the mouth or ereeted at will. The eanal in this fang eonnects with a duet or tube which leads to a poison gland on the upper side of the head. The poisonous liquid is separated frem the blood by this gland and, when the serpent strikes, from four to six drops of it are injected through the luct and fang into the wound.

The liquid itself is tasteless, green to orange in color, and about ten times as heavy as water. Freezing, boiling, drying or treatment with alcohol does not affect its virulence. In man, as in most other animals, the poison causes great nervous prostration, lessens the number of heart beats per minute, and produces 
something akin to blood poisoning. The best antidote, as well known, is alcohol taken inwardly in the for'm of whisky or brandy. This acts as a stimulant, bracing up the system and enabling it to withstand the depressing effects of the poison. When properly attended to not more than twenty per cent. of the bites of our poisonous snakes result fatally.

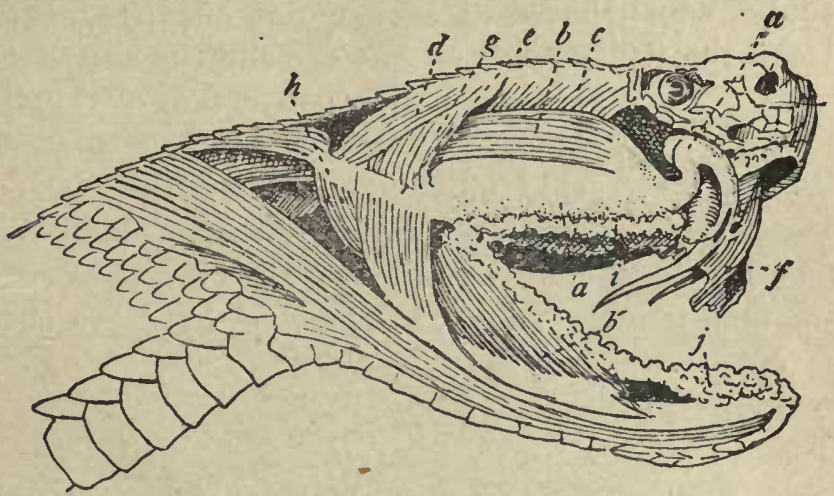

Fig. 7-Head of Rattle-snake, showing Venom Gland and Muscles. $a$, vonom gland; $a^{\prime}$, venom duct; $f$, shoath of fang; $b, c, d, g$ and $h$, muscles; $i$ and $j$, salivary glands.

Hogs are-seldom poisoned when bitten by a rattlesnake or copper-head, as their fatty tissue absorbs the poison and prevents it from entering the cireulation. Other animals usually die from the effects of the bite, even the snake itself succumbing to its own venom when it aecidentally wounds itself. In other words, the poison is a liquid seereted from the blood, which becomes fatal on being introduced back into the rery same source.

Of the three "pit-vipers" occurring in Indiana, the copper-head, Agkistrodon contortrix (L.), is readily dis- 
tinguished from the other two by having its tail devoid of a rattle and ending in a horny point. Sev-

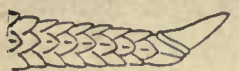

Fig. 8-Tail end of Copper-head. eral species of harmless snakes are, however, in many localities known as "copper-heads" and are, therefore, shunned as venomous. The most common of these is the spreading viper or hog-nose snake, which has a flat, triangular head, but which lacks the "pit" between the eye and the nostril and

The

Copper-head. marked difference is seen on the under side of the tail where the plates or scutes are, in the copper-head, mostly undivided, whereas in the spreading viper they are divided on the middle line. In color the copper-head is a chest-

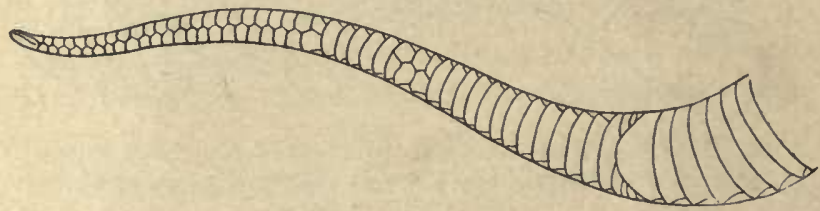

Fig. 9-Under side of tail of Southern Water-moceasin, a poisonous snake. (After Stejneger.)

nut or hazel-brown, with numerous darker $V$-shaped blotehes along the back. Its head is a coppery-red, whence the common name. It seldom, if ever, exceeds three feet in length, and its poison is less virulent than that of either of the rattle-snakes. On the other hand it is more justly feared than they, since it gives no warning of an attack but strikes viciously and repeatedly at whatever disturbs its repose.

\footnotetext{
The Copper-head has similar undivided plates.
} 
IV.

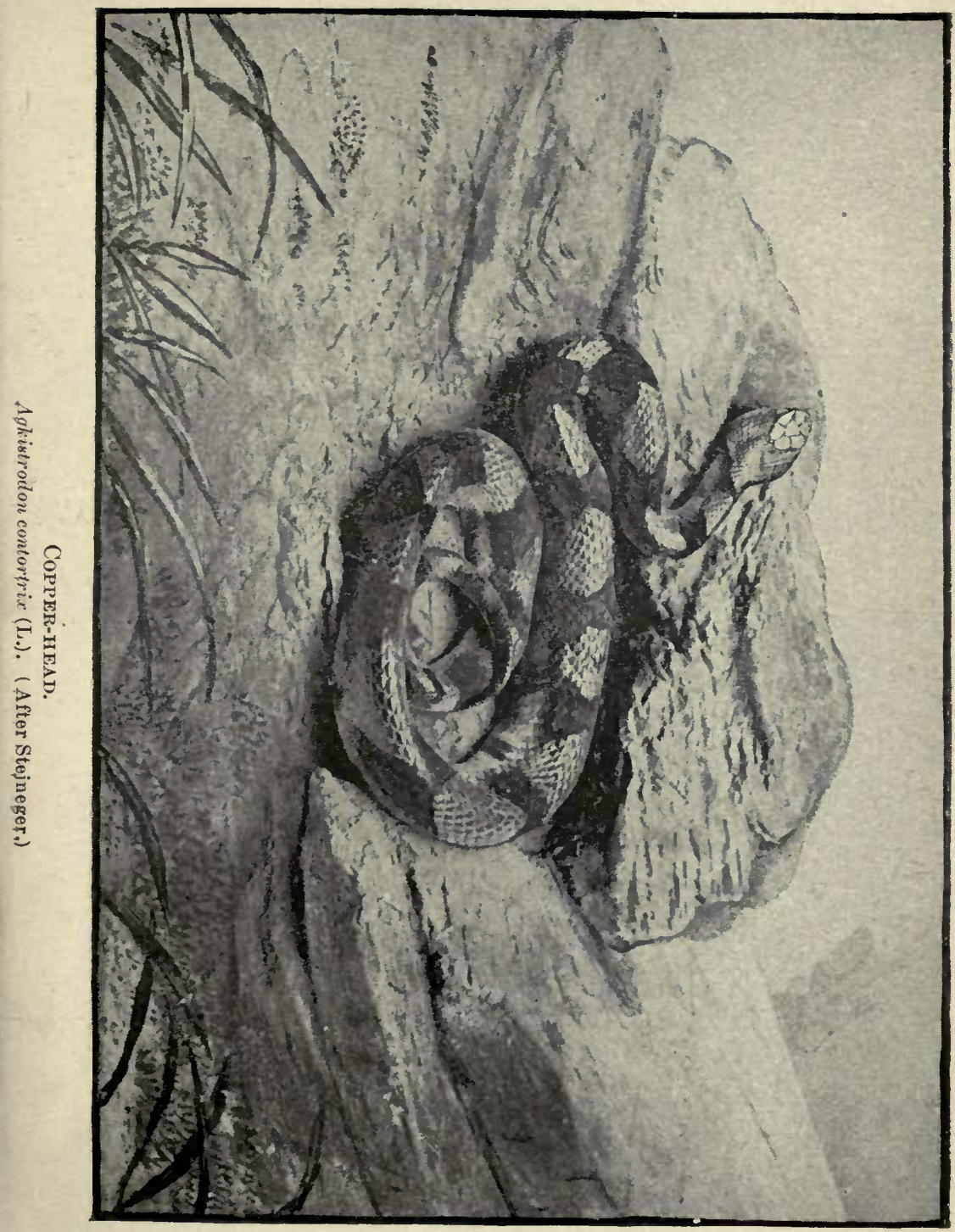



The copper-head frequents for the most part rocky hillsides, especially those covered with timber and in the vicinity of water. Its young are born alive, and are few, seven to nine, in number. In the
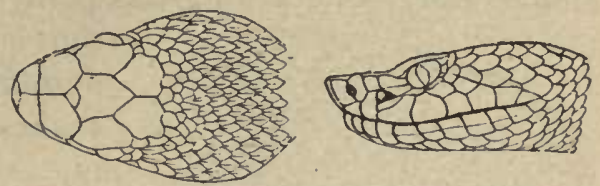
early settlement of Indiana it was common in the southeru half of the State, but at present one hears only of an oceasional specimen; the most of those which are reputed as copper-heads, being found, upon examination, to be examples of some harmless species.

The banded or timber rattle-snake, Crotalus horridus L., reaches a length of six feet,* and a diameter of several inches. From the prairie rattle-snake it may be readily known by its having the top

The Banded of the head covered with numerous or Timber

Rattle-snake. scales instead of bony plates. In color it is yellowish brown with three rows of dark blotches, about twenty-one in each row, along the back between the head and the tail, the latter, in full grown specimens, being entirely black.

The rattle of this and allied species is composed of a series of flattened, horny rings joined rather loosely together, the terminal one, called "the button," being narrower than the others. The common belief that the age of the suake can be told by the number of

*A specimen in the State Museum from Arkansas measures six fect four inches, and its rattle is composed of thirteen rings and a button. Another from Clay County, Indiana, is five feet four inches in length and possesses eighteen rings and a button. 
joints in the rattle is entirely erroneous, as many as four of the rings having been known to develop in a single year. Concerning this point Dr. L. Stejneger,

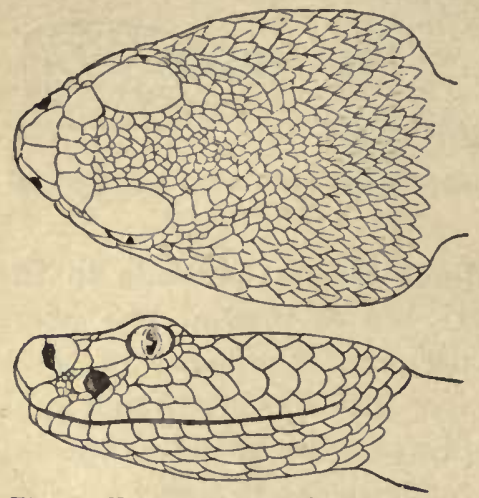

Fig. 11-Head of Banded Rattle-snake, shown from top and side. (After Baird.)

the leading American anthority on poisonous snakes, after mentioning the diffieulty in overcoming the fallacy that "each ring on a rattle-snake represents a year of its life," says : "It ought not to be difficult to make people understand that the rattle is a delicate instrument which easily breaks; that old and huge rattlers are often found with but one or a few rings; that a variable number of joints are added each year, and that the production of a ring can be accomplished in the course of every two or three months."

In what manner has so unique an organ as the rattle developed? For what purpose is it used by the

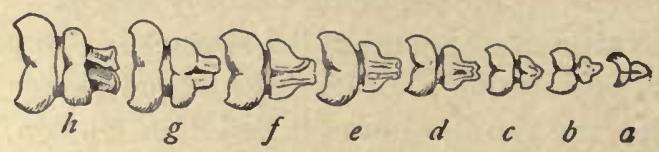

Fig. 12-Separate joints of rattle of Banded Rattle-snake. $a$, button; $h$, basal joint.

snake? These are questions which have been much discussed but are, as yet, unsolved. Some have likened the sound produced by the rattle to that made by the 


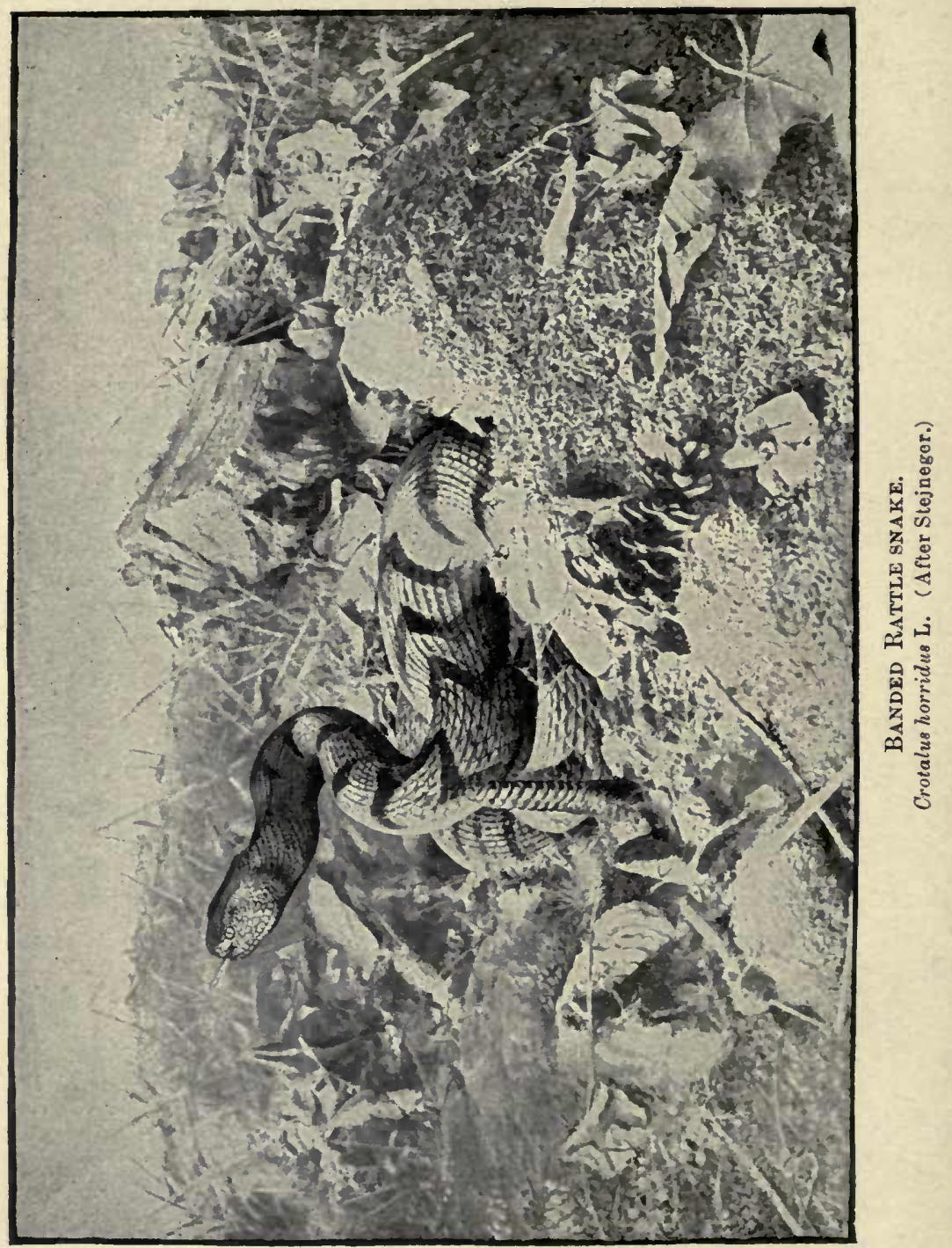


harvest-fly, Cicada tibicen L., or by certain species of grasshoppers, and have thought that the noise was made to "decoy insect eating . birds into the range of the serpent's spring." Others have elaimed that it was a love call used in bringing the sexes together. Still others have looked upon it as a "providential arrangement to prevent injury to innocent animals

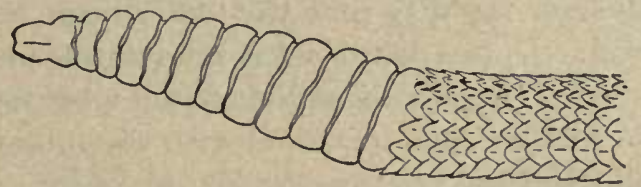

Fig. 13-Rattle of Banded Rattle-snake, (After Garman.)

and man." The most commonly accepted theory at present is that it is tised by the snake as a "means of self-protection, serving the same purpose as the growl of a tiger when threatened with danger. The snake seldom sounds its rattle until it considers itself discovered, and not then unless it apprehends danger. It throws itself in position to strike and says in unmistakable language: 'Look out for yourself, I am ready for you. Your life, if you injure me.' If pushed upon it makes its leap at its antagonist, and again throws itself in position to renew the eonflict, once again sounding the note of defiance." * In making its warning note the snake doubtless frightens away many enemies which by experience liave learned to shun its presence. In this way it saves its venom, for the use for which it is most evidently seereted-that of quickly destroying or rendering helpless those forms of life which the reptile needs for food.

* Henderson, J. G., American Naturalist, VI., 1872, 261. 
The young of the timber rattle-snake are born alive. They are seldom, if ever, more than nine in number, and average at birth about eight inches in length. Its food, in a state of nature, consists of rabbits, squirrels, mice, and frogs, with an occasional bird, or harmless snake to vary the menu. It usually lies in wait for its prey. and when the latter cones in reach it strikes at it with such rapidity that the motion can scarcely be followed. Unless disturbed it ignores the presence of man or of such animals as it does not wish for food, and never follows such intruders with the intention of attacking then.

Like the copper-head, the timber rattle-snake was once rather common in southern Indiana, and doubtless occurred in small numbers in the northern half of the State. At present it is known to occur only in the broken, wooded portions of such counties as Brown, Monroe, and Greene, where there are many ledges of stone, on which, in summer, it can bask for hours in the sunlight, and in whose crevices it can find in winter a suitable abiding place. But here, even, its numbers have become so few that the killing of one is thought to be of sufficient importance for a notice in the local newspaper, usually with a foot or two of length added to the specimen."

The prairie rattle-snake or massasanga, Sistrumis catenatus (Rafinesque), is, in general, smaller than the timber rattle-suake, seldom exceeding

The Prairie Rattle-snake. three feet in length. The top of the head is partially covered with hornlike shields or plates, similar to those of the harmless snakes. Its color is brown or blackish with seven rows 
of darker blotehes, 34 in each row, between the head and tail. Those specimens living in swamps and marshy places are often a uniform black in color.

In the wet prairies and marshes of northern Indiana the massasanga is yet found in small numbers, but is nowhere so abundant as it was a score of years ago. No record of specimens taken in the State south of the National Road has come to the writer's notice.

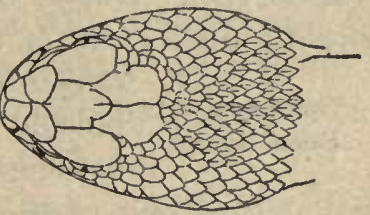

Aside from its poisonous qualities, its habits are beneficial, as it feeds upon field mice and insects, and thins airls Fig. 14-Head of Prairie Rattlein keeping in check those pests. Its bite is considered much less

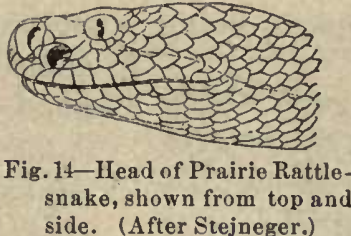
venomons than that of the timber rattle-snake, one observer having asserted that it is scarcely more to be dreaded than the sting of a hornet. This night be true if the person bitten were so situated that immediate medical assistance conld be obtained, but for persons living on a farm at some distance from a physician, the bite is always to be regarded as serious. The degree of danger from the bite of any of the poisonous suakes depends chiefly upon the size of the reptile, the amount of venom injected and the location of the wounded part. The larger the snake, the more venom it exudes and the deeper the fangs are driven into the body of the victim. If the wound is in such a part of the body that the poison is injected directly into the cireulation the 
chances for recovery are small, no matter if the promptest of medical attention is obtained. Happily, such a bite does not often oceur.

The fourth and last species of poisonous reptiles occurring in Indiana is the coral or bead snake, Elaps fulvius (L.). Unlike the "pit vipers," its head is but slightly distinet from the body. It lacks the pit between the eye and nostril, and the

The Coral or Bead Snake. poison fang of the upper jaw is permanently ereet instead of novable at will. It is one of the most handsome of American snakes, being possessed of a slender body which is
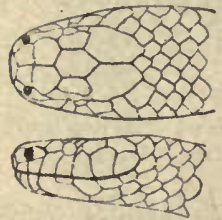

Fig. 15-Head of Coral Snake, shown frow top and side. (Alter Baird.) encireled by alternate bands of jet black and bright red, the latter color merging into yellow near the edges of the bands. The front portion of the head is black, while the hind portion is encircled by a band of bright yellow. The total lengtl is less than $2 \frac{1}{2}$ feet.

In the southern States the bead snake is rather common and the extrenie northern limit of its range is probably the southern half of Indiana and Ohio. In this State, but a single specinen, taken near Milan, Ripley County, has been recorled. Of its food habits but little is known, but that little goes to show that it is a camnibal, eating hamless snakes with evident gusto, since Dr. Stejneger recorls one as having swallowed a black snake as long as itself, before it had fully digested a garter snake taken at a previous meal. Much discussion has taken place concerning the ability of the coral snake to inflict dan- 
gerous bites. There is little doubt, however, but that it injects a true poison which sometimes causes fatal results, but on account of the smallness of the serpent's mouth and the shortness of its poison fangs, the wound must be inflicted on the more exposed portions of the body, as the finger's or toes. It is hoped that persons in the southern half of Indiana will, in the future, be on the lookout for this snake, that a more definite account of its range in the State may be put on record.

\section{HARMLESS SNAKES.}

Fol convenience the twenty-five species of harmless snakes known to ocenr in Indiana may be elassed according to color, habits, etc., into seven groups. Three of the reptiles are seldom found far from ponds or streams, and hence may form

\section{Group I.-The Water Snakes.}

Two of these are quite similar in habits and appearance, the ground color varying fiom ashy to brown, with a row of thirty or more darker spots on the back between the head and tail, and a row of smaller, similar spots on each side. Seientists distinguish them, however, by the difference in the number of rows of scales on the back, giving to the rarer one, which has 27 rows, the name of "diamond water snake."

The other one, which has but 23 , rarely 25 , rows, is Tropidonntus siperlon (L.), one of our most common snakes and popularly known as the "water snake," 
"spotted water snake" and "water moceasin." About the larger ponds and streams, especially those of southern Indiana, it grows to a large size, reaching a diameter of three inches and a length of five feet; but in the central and northern parts of the State specimens more than four feet long are seldom seen. It is usually given a wide berth, as seven people out of ten believe that its bite will cause certain death. This belief is no doubt caused by the fact that the

The Spotted Water Snake. "water moccasin" or " cotton mouth" of the southern States is a poisonous snake, and the common names of the two have become confounded. Our water moccasin

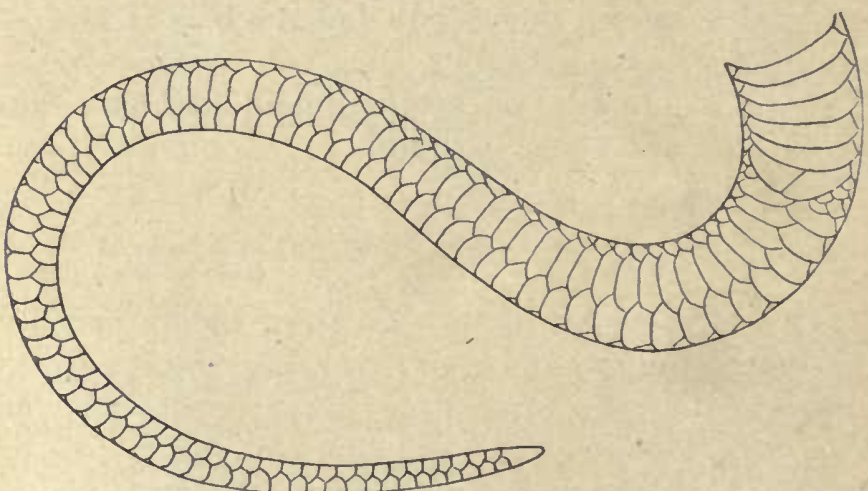

Fig. 16-Under side of tail of Spotted Water Snake, showing divided plates or scutes. (After Stejneger.)

has no fangs whatever, and its bite is never more serious than that of a monse. It is partial to still waters of considerable depth, and seldom frequents streams that have not a bottom of deep, soft mud, in which to take refuge when pursued, and in which it buries 
itself deeply during the winter. It delights in the piles of driftwood which collect about such pools, and on a midsummer day three or four may be seen stretched out on the sane log, evidently enjoying the sunshine and awaiting the near approach of their farorite prey, the leopard and bull frogs. Sometimes another snake, swimming too near, pays with its life the penalty of its rashness. Minnows also, doubtless, form a large proportion of their food, and an instance is on record where an individual of this species was surprised with a pickerel a foot long in its mouth.

The young of the water snake and its near allies are hatehed from eggs either within the body of the mother, or very soon after the eggs are laid, and as many as 33 have been recorded as belonging to a single brood. Several eolor varieties of this water snake necur in Indiana, one of which, a uniform blue-black above and reddish beneath, is known as the "black water moccasin," Tropidonotus sipedon erythrogaster (Shaw).

The diamond water snake, Tropidonotus rhombifera (IIallow.), is, as above mentioned, a distinct speeies, known by its 27 rows of strongly keeled scales; i. e.,

The Diamond Water Snake. scalles with a ridge extending lengthwise of the center of each, and by the squarish brown spots on the back alternating with those on the sides and connecting with them at the angles. Several specimens of this snake from southern Indiana are in the State Museum, one of which, from Morgan County, was labeled "Copperhead-Trigonocephalus contortrix-A poisonous Anerican Serpent, called also eopperbell and red viper." 
The diamond water snake reaches a larger size than the common water snake, and the two are often confounded by observers. Its habits are essentially the same as in that species. Both strike viciously when disturbed, and exhale a very disagreeable odor when handled, this being, probably, their most efficient means of defense.

The third species of water snake found in the State is the queen or leather suake, Regina leberis (L.), a much smaller and more slender reptile than either of the last two, seldom exceeding two feet in length. Its scales are keeled and occupy 19 The Leather rows, while its color is olive brown
Snake. with three narrow black stripes on the back and a yellowish band along the side. Beneath, it is yellowish with two brown bands which lie close together and reach from the head to the tail.

Along the rapid flowing streams of central Indiana this is a very common snake, and it probably occurs thronghout the State. It frequents, for the most part, shallow rumning water, gliding gracefully among the stems of the water willow, Dianthera americana L., and other aquatic plants; and, when pursued, taking refuge beneath some that stone, or the piles of driftwood along the shore. It is never, as far as my observation goes, found at any distance from water, and its food consists mainly of small "peeper" frogs, young toads and minnows.

\section{Group II.-Black Snakes.}

To this group belong four species of our largest snakes. The ground color of each of them is black, 
and the eommon name of "black snake" is indiscriminately applied to them. However, a little practice soon enables one to distinguish them apart. The most common of the four and the only one to which the name rightfully belongs, is Bascanion constrictor (I.), a snake which is a uniform deep black above, paler beneath, and has the scales on the back perfectly smooth and in 17 rows. The young, up to the third moult, are very different in eolor from the adult, being olive brown with numerous large,

The

Black Snake or Blue Racer. darker colored spots along the sides. When they are about two-thirds grown, the hue is of a bluish slade, and they are then commonly known as "blue racers"; most people believing them to be an entirely different snake.

More "lies" have been told about this snake than any other one in existence. It " charms birds," "sucks cows," "steals eggs," "drinks the milk in the milk houses," "kills a rattle-snake by pulling it in two," and does fifty other deeds that no snake on earth ever did or ever will do. One thing, however, it can do, and do well, and that is to turn tail and run when approached, seeking a shelter with "that celerity of movement no other creeping creature can obtain."

The black snake feeds principally upon rats, mice, crickets, grasshoppers and beetles, and may oceasionally swallow another snake or a small bird Fig. 17-Head of Blaek Snake. for dessert. However, the good

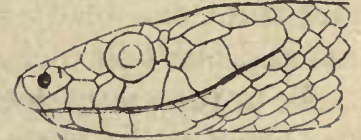
(After Baird.) that they do far outweigh the bad, and yet every 
year their numbers are becoming less, for "death to the black snake whenever and wherever found" seems to be the watchword of all boys and most men. Another cause for their lessening numbers is undoubtedly the rapid disappearance of the old Virginia rail fences, beneath the bottom rail of which they were formerly sure of a safe retreat from all attacks.

At certain seasons of the year, as in spring when mating, and in late autumn, when seeking a hiding place for the winter, the black suake is vicious, hissing and striking at a person who is several yards away. At such a time it will occasionally pursue a person whom it recognizes as more cowardy than itself, and in this way has probably gained the name of the "blue racer." When seized by the neck it quickly throws a double coil about a person's arm and gives a grip with its powerful muscles which the captor has no little difficulty in breaking. The stories which one often hears of its attacking persons and squeezing them to death are wholly without foundation. The young - are hatehed from eggs which are usually deposited in soft earth or the humus of decayed wood. These egg's are an inch and a lialf long by an inch in dianeter, and covered with a tough, thick skin. According to Dr. Hay, as many as nineteen eggs are laid at a time, and from one ready to hatch he took a young racer ten and one-half inches loug.

As to the many stories concerning the size to which the black snake grows, mention has been made on a previous page. A little over six feet is donbtless their maximum length, yet they are often said to have been seen eight and even ten feet long. In regard to the 
length of snakes generally, Dr. C. C. Abbott in one of his charming books has well said: "that with timid people, a great deal depends upon the direction in which the snake was moving at the time it was seen. As an old, observing friend once said to me, "When snakes come towards folks, every foot looks a yard long.",

One of the largest snakes found in Indiana is the "pilot snake" or "black racer." It is often confounded with the true black snake

The Pilot Snake. or "blue racer," but has the scales in

25 to 29 rows instead of 17 , those along the middle of the back being obscurely keeled. In the place of being uniformly black above, it usually has some of the scales white-edged, thus causing some fine white mottlings on the upper side.

The pilot snake at times grows to be six and onehalf feet long and the body is always much thicker than that of a black snake of the same length. It frequents dry, open woods and thickets, and more often than any other of our suakes is scen in bushes, and even in the tops of tall trees where it has climbed by following the depressions in the rough bark. Although its bite is harmless, yet it is, probably, our most injurious snake on aceount of its liking for small birds, which form one of its principal foods, and for which it undoubtedly lies in wait in the bushes and trees. Field mice and insects form also a large portion of the food, so that it makes up in part for its depredations among the birds.

The young of the pilot snake are hatched from eggs which are deposited by the mother in such places as 
hollow stumps and close alongside old logs. The young, for the first year or more of their lives, are ashy gray with about 45 square, chocolate blotches on the back, and a row of alternating smaller blotches along each side. There is also a dark band between the eyes, and the foremost spot on the back is forked, each division extending a short distance onto the head. One of these young, 16 inches in length, which contained a large shrew, partially digested, was taken June 11, 1894.

A pilot snake over five feet in length was once kept by the writer in a vacant room with a great horned owl, some turtles and salamanders. It was supposed that the size of the owl, which is one of our largest birds of prey, and has a very strong beak and talons, would prevent a conflict, and that a "happy family," equal in interest and peaceful inclinations to any seen in a menagerie, would result, but events proved otherwise. One night a strange noise was heard in the room, and on investigating its cause it was found that a "struggle for existence" had taken place between the two leading members of the family. Whether the snake attacked the owl or the owl the snake was never known, but the snake proved itself the "fitter in the struggle," and quickly squeezed the life out of the owl by wrapping two coils tightly about it. Perhaps the snake would, if let alone, liave attempted to swallow the owl, but a desire to secure the latter in as good a condition as possible for a permanent specimen led to its immediate removal from a literal embrace of death. 
A third snake, which reaches a length of four feet or more, and which in the country usually goes also by the name of "black snake," is the king snake, Ophibolus getulus sayi (Holbrook). It is less common

The than either of the last two mentioned. King Snake. From them it may be known by the seales being smooth and in 21 rows. Many of the scales have a small yellowish spot in the center, and in young specimens these spots often unite to form eross lines on the back. These lines sometimes fork on the sides and divide the black of the back into large blotches. It will thus be noted that the young of many black or dark colored snakes are always spotted, and that as they grow older and shed their skins a number of times they gradualiy grow darker, until finally they become almost wholly black. This has, in the past, been the cause of much confusion in the naming of the reptiles, many of the young having been thought to be distinet speeies.

The king snake frequents open woodlands and the borlers of moist thickets, feeding upon mice, moles, toads, salamanders, and, as noted near the beginning of this paper, upon such other snakes as it can conveniently swallow. It is a very active reptile, but in general mild and inoffensive in its habits. When cornered, it will strike rapidly and viciously, causing the timid person who has suddenly come upon it to beat a hasty retreat.

In some of the southern States, where it is more common than in Indiana, it is.reputed to wage a suceessful warfare upon the rattle-suake, and hence received its common name. A prominent writer and 
generally accepted authority on snakes, evidently trying to excel some newspaper reporter in the production of a snake story, avers that: "By suddenly springing upon and encircling the rattle-snake with its coils, the king snake soon squeezes the venomous reptile to death. Then, commeneing at the head, the victor swallows the rattler whole."

The last species which belongs to the group of black snakes is the horn snake,Farancia abacura (Holbrook). It is said to be rather common in the southwestern States, but in Indiana has been taken only neal Wheatland, Knox County. It is a handsome species, as handsome goes among snakes, being blue-black above with about sixty squarish red The Horn Snake. spots on the sides. These, in some specimens, extend nearly to the middle of the back. Beneath, it is red, blotehed with black. The scales are smooth and in nineteen rows.

Having never met with this speeies alive, I can.say but little of its habits. Aceording to its first deseriber, it is shy and lives in swampy ground and damp thickets. It reaches a length of four feet or more. People in the southern half of the State should be on the lookout for it, and if a specimen is secured it should be sent to the State Museum or presented to some school which will preserve it for future reference.

\section{Group III.-Spotted Snakes.}

Among the harmless snakes occurring in Indiana, which are usually found at some distance from water, are four species of medium or large size which are 
distinctly spotted throughout their entire lives. One of the most handsome of these, and one quite frequently met with in dry, upland woods, and about country honses and barns, is the "spotted adder," Ophbolus doliatus triangulus (Boie.), "house snake," "milk snake," "thunder and lightning snake," or

The House or
Milk Snake. almost anything else one may wish to call it, as it is a creature of many names, of which the above are the most common. It varies much in color, but is usually grayish with three rows of brick-red, blackbordered blotches on the back and sides; the larger ones saddle-shaped and alternating with the smaller, the latter being often wholly black. There is usually a light colored arrow-shaped spot back of the head, while beneath, the body is checkered with black and creamy white. The seales are smooth and in 21 rows. The young are hatched from eggs which are about two inches long and a little more than an inch in diameter. During the first year of their lives they are often found beneath the loose bark of logs and stumps, where they are donbtless seeking the erickets, cockroaches and other insects which have there their abiding places.

The house snake sometimes reaches a length of four feet, and when disturbed resents only by darting out its forked tongue and giving an occasional vibration of its tail. Its usual food consists of mice, rats, and such unfortunate toads as happen in its way, except in grasshopper season, when it feasts to its stomach's content upon those festive insects. It is often found abont spring houses where milk is kept, 
presumably in search of frogs and salamanders which frequent such damp localities; but the owner of the milk usually asserts that it drinks that lacteous fluid and hence gives it the name of " milk snake."

In rare instances double-headed specimens of this snake have been taken. The writer has seen one in which the two heads were each about three inches long and then uniter into one body.

According to scientists, the house snake is only a color variety of the red snake, Oplibolus doliatus (L.). The latter is red or scarlet and has 20 or more pairs of black rings, each pair enclosing a yellow spot. Its habits are essentially the same as those of the house snake, but it is much less common and seldom grows above two feet in length. It has been taken in a number of localities in southern Indiana, but in the north only the more spotted variety has, as yet, been found.

Another spotted reptile elosely allied to the house snake is the chain snake, Oplïbolus calligaster (Say). Its smooth seales are in 25 rows, and it has about 60 squarish chestnut-eolored blotches along the back

The Chain Snake. which alternate with sualler rounded spots along each side, the ground color being olive gray.

The range of the chain snake is western, and but a single specimen is so far known from Indiana. It was taken by the writer from open woods just east of Terre Hante in Vigo County, and is about three feet in length. Nothing distinctive is known of its habits, though in Illinois it is said to fiequent prairies, where it doubtless lives mainly upon small mammals and insects. 
The fox snake, Coluber vulpinus (B.\& G.), is a third distinetly spotted snake which is found occasionally in Indiana. The ground color is light brown or grayish-yellow, and there are about 60 choeolateThe Fox colored spots across the back, which Snake. alternate with smaller ones on each
Snex side. It may be known from the chain snake by its having nine or more of the 25 rows of scales keeled. The under surface is yellowish, with large squarish blotches of black.

The fox snake feeds upon the smaller mammals, as half-grown rabbits, mice and ground squirrels. Like most snakes it is irritable and vicious when surprised immediately after swallowing its prey, evidently fearing that the intruder will cause it to disgorge the latter and so deprive it of its dinuer.

The fourth species of spotted snakes oceurring in the State is the corn suake, Coluber guttatus L., a reptile of sonthern range, which has been taken at a few localities in southern Indiana. It is thought by some to be only a variety of the fox snake,

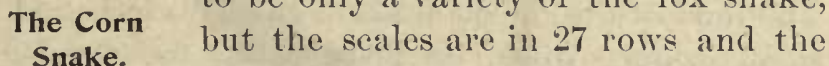
ground color is brick-red instead of gray. The dark blotches are also fewer, being seldom more than 45 .

Not having seen the corn snake alive I can say nothing of its habits. IJolbrook says that in North Carolina "it is found about the roadsides early in the morning or at the dusk of evening, unlike most snakes concealing itself during the day. It is very gentle and familiar . . . at times entering houses, and is, according to Catesby, a great robber of hen-roosts." 


\section{Group IV.-Striped or Gurter Snakes.}

Four slender bodied reptiles, whose general color consists of three light stripes on a darker ground, with sometimes intervening darker spots, and with the lower side unspotted, belong to this group of harmless snakes. The seales of all are keeled and in 19 , rarely 21, rows.

Of these the ribbon snake, Eutainia saurita (L.), is much more slender and graceful, and withal a hand-

The Ribbon

Snake. somer species than any other, its color being a dark, glossy, chocolate-brown, with the three stripes of a bright greenish yellow. It reaches a length of three feet or more, and its favorite haunts are damp thickets and the borders of streams and ponds, where; on the first bright sunny days of spring, several may sometimes be found in close proximity. It often takes to water to escape its enemies, swimming with graceful curves of its long slender tail, but it is by no means aquatic in its habits. The food of the ribbon suake is chiefly insects and the small cricket frogs, its body being too slender to encompass many of those larger forms of life in which other snakes delight. A stouter bodied, larker colored variety of this species is sometimes called Fairey's garter snake.

The common garter snake, Eutainia sirtalis (I.), is the most common reptile in the United States, and at the same time one of the nost variable. Four varieties are known to oceur in Indiana as follows : 
(a) Grass snake, E.s.graminea Cope ; eolor, green, lacking both stripes and spots, except a small black spot near the end of each ventral plate.

(b) Spotted garter snake, E. s. ordinata (L.); lacks the stripes, but has three distinct rows of square dark spots, on each side between the head and tail; and also a small black spot at the end of each ventral plate.

(c) Red-sided garter snake, E. s. parietalis (Say); has the stripes present, yellow or greenish, and a row of briek-red spots alternating with a row of darker colored spots along the sides.

(d) Common garter snake, E. s. sirtalis (L.); has the stripes present but faint and narrow, with three rows of indistinct dark spots on each side.

These varieties are named in the order of their relative abundance in Indiana, the grass snake being scarce, while in the course of the summer more of the red-sided and common garter snakes The are probably seen than of the individCommon Garter Snake. uals of all other species combined. They are to be found anywhere, but prefer the vicinity of water, where frogs and other snake food is most abundant. When teased, they flatten the body, elevate the scales, hiss and exude a disgusting odor. Sometimes they strike viciously and may even draw blood with their needle-like teeth, but their bite is less harmful than that of a mosquito, as it causes no swelling or after pain. The young of the garter snake are born alive in late summer or early autumn, and their number is legion. Dr. J. Sehneck, of Mt. Carmel, Illinois, has recorded* the taking of

*American Naturalist, XVI, 1882, 1008. 
78 from three to seven inches in length from the body of a single female 35 inches long. Other observers have noted from 35 to 80 .

This snake has many enemies, among which may be mentioned owls, hawks, hogs, skanks, ducks, turkeys, other snakes, and last but not least, the small boy with a big club. Feeding as it does mainly upon insects and the smaller injurious mammals, the good that it does far outweighs the bad. In the future, therefore, let its presence in the dooryard be looked upon with favor, and let the hand be stayed that in the past has ever been raised against it.

The Racine garter snake, Eutainia radix (B. \& G.), has been taken in a few localities in western Indiana. Prof. E. D. Cope says that it is the prevailing garter snake of the westem plains, ranging from the base of the Rocky Mountains on the west to the eastern limit of the prairies in Indiana on The the east. Its. scales are usually in 21 Racine Garter Snake. rows and are prominently keeled so
that the reptile is very rough in Garter Snake. rows and are prominently keeled so appearance. In eolor it is dark olive brown with the lateral stripe on the third and fourth rows of scales instead of on the second and third, as in the common garter snake. The stripe on the back is bordered with black and there are two rows of dark sjots on each side between the stripes. Below the lateral stripe there is also an additional row of small spots. The average length is about two feet.

The habits of the Racine garter snake are essentially the same as those of the nore common species. Living as it does mainly in prairie regions it is largely. 
preyed upon by hawks and in turn preys upon the smaller mammals. These live upon the insects, which gain their sustenance from the grass and grain. Thus, by tracing back the food of each, we realize the force of the old saying: "All flesh is grass," and know that the plant must have existed before the insect, reptile, bird or mammal made its appearance upon earth.

Butler's garter snake, Eutainia butleri Cope, was described from a specimen taken near Richmond, Indiana. But two additional specimens have since been seeured, one at Waterloo, Dekalb County, and the other near Turkey Lake, Kosciusko

\section{Butler's}

Garter Snake.

County. It is distinguished by the yellow, black-bordered lateral stripe covering three instear of two rows of scales, and by its head being nuch smaller and more conical than in the typieal garter snakes. The eye is also proportionally smaller than in any other of the more common species. Nothing distinctive of its habits is known, and additional specimens are greatly to be desired.

\section{Group V.-Green Snakes.}

Of all our reptiles not one can exceed in beauty and gracefulness the "green" or "summer snake," Cyclophis cestivus (L.) It possesses 17 rows of keeled seales and in color is a uniform bright green above and light yellow beneath. With a body remarkably slender for its length, which at times reaches thirty or more inches, it is an object which delights the eye of 
the nature-loving rambler whenever he is so fortunate as to meet with it. The favorite haunts of the summer snake are rocky hillsides, The
Summer Snake. especially those in the vicinity of
running water. Oftentimes, too, the seeker after wild berries is needlessly frightened by seeing one reposing on the bushes within a few inches of his out-stretehed hands. One of these snakes, kept in captivity by the writer, often rested on the posterior half of its body, and, raising the front half almost vertically, it would remain rigid and motionless for half an hour at a time. In its wild state such a habit, if practiced, would render it, for the tine being, very secure against such enemies as were guided only by the sense of sight, and would allow the near approach of such small animals as the snake subsisted upon.

The habits of this species were excellently portrayed by Dr. Holbrook, who wrote of it as follows: "The summer snake is perfectly harmless and gentle, easily domesticated, and takes readily its food from the hand. I have seen it carried in the pocket or twisted around the arm or neck as a plaything, without ever evincing any disposition to mischief. In its wild state it lives among the branches of trees and shrubs, shooting with great velocity from bough to bough, in pursuit of the insects which serve as its nourishment. Its green color, similar to the leaves among which it lives, affords it protection against those birds which prey upon it."

Another green snake, as handsome as the one last mentioned, and distinguished from it only by its scales 
being smooth and in 15 rows, is the smooth green snake, Liopeltis vernalis (DeKay). It is much less

The Smooth Grèen Snake. common in Indiana than the summer snake, and is found usually in the tall rank grasses which grow about the margins of marshes and swamps. There it lies in wait for the green grasshoppers and katydids which are so abundant in such a place. Except in these grasses it is seldom seen higher than the surface of the ground. Its eggs, an inch and a half long, were found by one observer beneath the bark of an old stump, and one young snake, just hatched, was five inches in length.

\section{Growp VI.-Small Brown Snakes.}

The snakes heretofore mentioned comprise the giants of the family as found in Indiana. We shall now deal for a time with the dwarfs. Six of the 29 species oecurring in the State, when full grown, seldom, if ever, exceed 16 inches in length.

The most eommon of the six is known as DeKay's brown suake, Storeria dekayi(Holbrook). It is grayishbrown in eolor, paler beneath, has a narrow pale band

\section{DeKay's}

Brown Snake. along the back and a dark spot behind each eye. The scales are keeled and in 17 rows, and the average length is about one foot. This is one of the first snakes seen in the spring, a specimen having been taken by the writer as early as April 2nd. Like many other species it is then usually found close to water, and doubtless breaks its long fast upon one of the small "ericket" or "peeper" frogs, whose shrill and countless voices 
make the welkin ring on just such days as tempt the suake forth from its winter's retreat. As these frogs, small as they are, are fully twice the diameter of the snake, it is doubtless with much effort that this. first spring meal reaches its final resting place in the latter's stomach. Later on in the season young and tender grasshoppers and crickets furnish them a bountiful repast, and it is even affirmed of them by Abbott that "they are excellent fishers, and gliding through the water with marvelous celerity, they catch minnows and young pike in large numbers." The young of this species, as well as those of the next, are hatched from eggs within the body of the mother, and number from eight to fifteen.

Another snake which, from above, closely resembles the last mentioned in color and size is Storer's brown snake, Storeria occipitomaculata (Storer). Its scales, however, are in 15 rows, and on Storer's Brown Snake. turning it over, a difference can be readily seen as it is a deep salmon-red beneath, whence it is often called the "red-bellied brown snake." Its usual home is beneath logs and stones where it feeds upon crickets, myriapods, slugs, earth worms and other crawling creatures.

On one occasion while driving in Vigo Connty the writer saw a chicken running along the roadside with a wriggling snake in its bill. After a sharp chase of the fowl through a rail fence and a blackberry patch, its prey was dropped and proved to be a fine specimen of Storer's suake. As soon as it found itself free it wrapped its tail about a small bush and when approached flattened itself very much after the man- 
ner of a spreading viper. The row of brown dots bordering the pale band along the back then became much more prominent than they were when the body resumed its nolmal sliape.

Most snakes have a head larger than, and distinct from, the body, but there are two occurring in Indiana which lave the head indistinct, it being at the base of the same width as the body whence it tapers gradually to a dull point. The more common of the two is the ground suake, Carphophiops amonus. (Say). Twelve inches is its maxThe Ground or
Worm Snake. inum length, and on account of the small size and the tapering head it is often called the "worm suake." In color it is a glossy chestnut-brown above and red or pinkish below, while the scales are smooth and in 13 rows. It lives, for the most part, coileck up beside or beneath rotten logs, among dead leaves, and about the roots of trees. In such places it readily makes its way, foreing its sharp muzzle into narrow erevices with nuch nuscular streugth. Such surroundings also harmonize with its colors, and crickets and other.

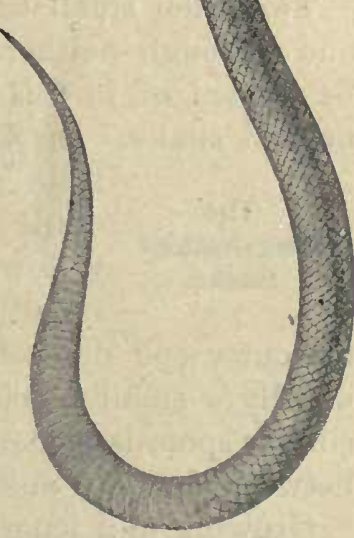

Fig. 18-Ground or Worm Snake. 
snake delicacies are there plentiful-two eonditions of life, which, if a snake possess, fully satisfy it here below. It is perfectly harmless, not being able to open its small mouth sufficiently wide to bite a person if it would; although by twisting about one's wrist or finger it may eause an involuntary snaky shudder to ereep up his back.

The second species with the conic head indistinct from the body is Virginia's snake, Virginia. elegans Kennicott. It is light olive brown above and yellowish beneath, while scattered over the Virginia's Snake. uppersurface are numerous small black dots, resembling points made by a fine pen. The seales are in 17 rows, very narrow and faintly keeled. In Indiana Virginia's snake has been recorded only from Brown Connty. Its habits are unknown, but presumably the same at those of the worm snake, since it frequents similar localities.

Two other small snakes remain to be mentioned, and although neither is strictly brown yet they will be treated of in this connection. One is the "ringnecked snake," Diadophis punctatus (L.), a handsome little reptile, blue-black above, pale

The

Ring-Necked

Snake.

orange below, and with a conspicuous yellowish ring about the neck. The smooth scales are in 15 rows, and on the outer end of each of the ventral plates there is usually a small black spot, while a median row of similar spots is sometimes present on the under side between the head and tail.

Growing to a length of a foot or more, the ringneeked snake is usually found beneath the loose bark 
$+8$ 
VI.

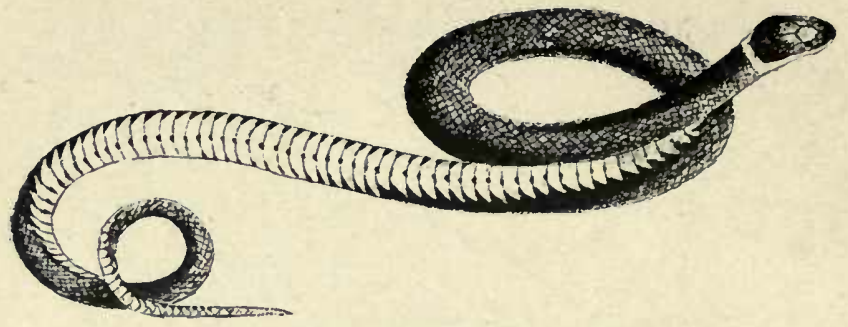

I. Ring.necken Snake.

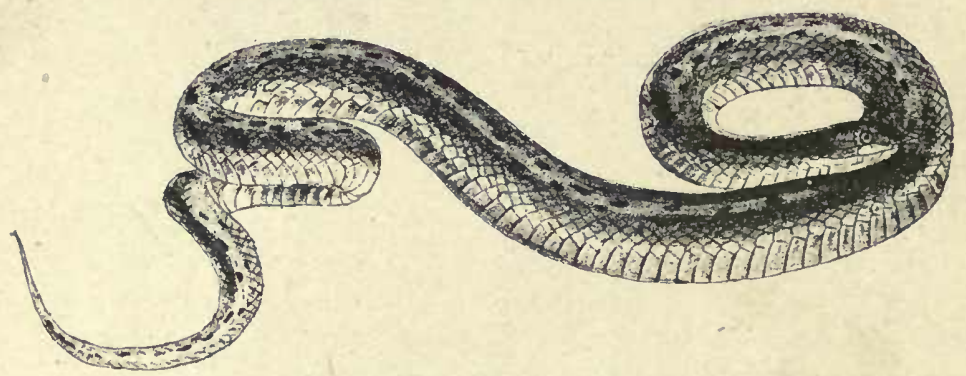

II. DeKay's Brown SNake.,

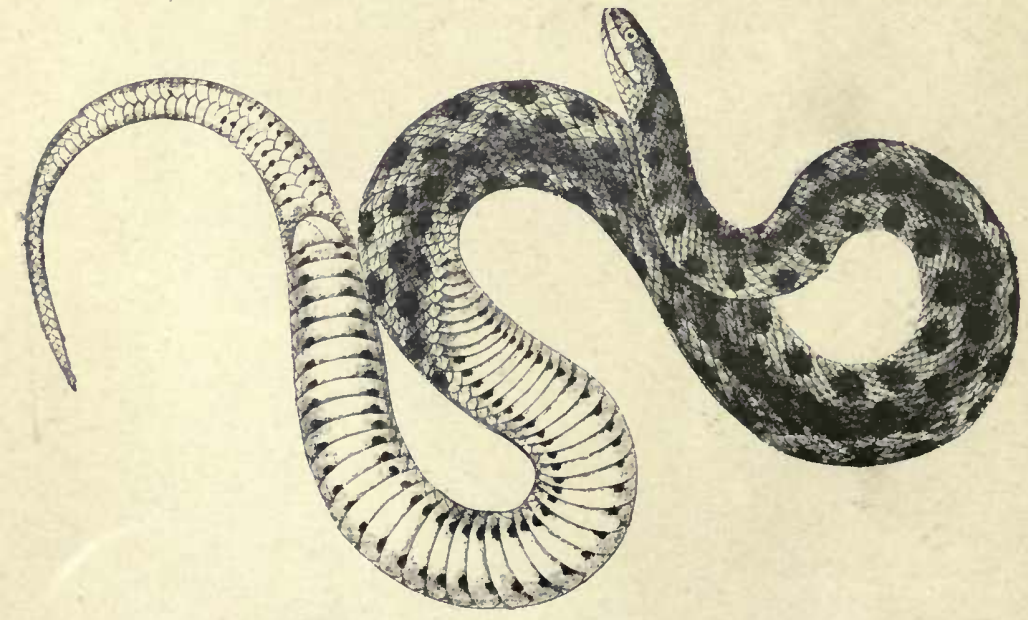

III. Kirtland's Snake. 
of a fallen tree or under a chunk on some dry hillside. In such a place it feeds upon those inseets which come readily to hand and, when disturbed, seeks to defend itself only by exuding a disagreeable odor.

More common than the above, especially in central Indiana, is Kirtland's snake, Tropidoclonium kirtlandi (Kennicott). It also is very prettily marked, being light reddish brown with two rows of large round dark spots on each side, while beneath

Kirtland's Snake. it is a bright salmon red, with a row of black spots along the margin of the ventral plates. The seales are keeled and in 19 rows.

This snake evidently feeds at night, for of 20 or more taken by the writer, all were found coiled up beneath logs or stones, seeningly half asleep, as they were very sluggish in their actions even after their chosen shelter had been rolled from above them. Its only show of self defense is a habit of flattening itself so that it becomes very broad and thin. It then strikes viciously for several times, when, seemingly satisfied with its show of resistance, it coils itself up and quietly eyes the intruder. Toads, frogs and insects comprise its food, and the young are born alive.

\section{Group VII.-The Vipers.}

And now we come to the last, the ugliest and the clumsiest of then all, the "hog-nosed snake" or "spreading viper," Heterodon platyrhinus Latreille. Much has been said of it on the previous pages but it deserves more than a passing mention, as none other of our suakes can hiss more loudly, spread more flatly, 
or snap more fiercely; and none other, as commonly met with, is as much feared as this. And yet, in

The Spreading spite of all these threatening actions, Viper.

its bite is perfectly harmless, as the writer knows by experience. It has no sign of a poison fang and no duct eonnecting with a poison gland. Aside from its actions the spreading viper may be known from other Indiana snakes by having the snout brought to an edge along the sides and to a point in front, and then turned up so as to

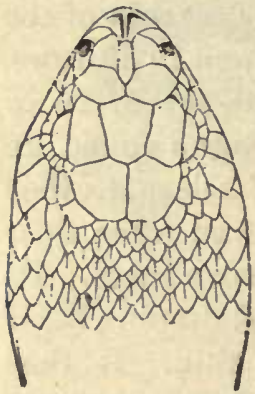
resemble a pointed dirt shovel. In color this snake is either uniform black, or a yellowish brown with about 28 darker blotehes on the

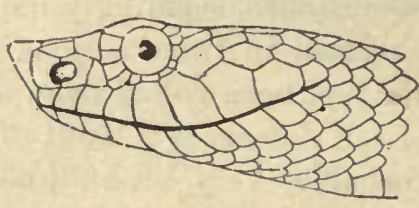
back and sides. The spotted form is the o n e most Fig. 19-Head of Spreading Viper, shown from top and side. u s u ally seen but the other in this vicinity is not rare. The seales are keeled and disposed in 23 or 25 rows. It sometimes reaches a length of three and a half feet and is then possessed of a thick and heary body.

A closely allied form, both in structure and habits, is the "sand viper," Heterodon simus (L.), which inhabits the southern States and has been taken in Indiana at New Harmony and Brookville. It is distinguished from the spreading viper by having the central plate of the head surrounded by five to ten small plates. It seldom exceeds two feet in length and the scales are sometimes in 27 rows. 
The young of the spreading viper are hatehed from eggs which are buried in loose soil, sand or the humus of decayed logs. The eggs are about $1 \frac{1}{4} \times \frac{3}{4}$ inches in size and covered with a tough, yellowish membrane. As many as 27 are known to belong to the same batch. When just hatched the young are about 8 inches in length and are ready to hiss, flatten the body and strike viciously whenever teased.

A singular habit possessed by the spreading viper is that of sometimes feigning death when disturbed. This is more often indulged in in early spring soon after they have left their winter retreats and while they are seeking their first spring meal or choosing their future mates. On March 23, 1893, a black specimen was found coiled up in some dead leaves in an open place in the woods. On being teased it went into a "fit," turning on its back with its mouth wide open and its tongue protruded at full length. Whenever it was turned right side up it would immediately turn on its back again. If held right side up with a stick it would squirm vigorously and endeavor to turu over. It was left lying bottom up, but on my returning to the spot a half hour afterward had disappeared.

On another oecasion a black and a spotted one were found in company and when disturbed they opened wide their mouths, turned on their backs and coiled and twisted about in a very rapid and curious manner for about five minutes, when they became quiet and apparently lifeless. During all these eontortions they had remained on their backs, and when they became quiet and were turned oyer they would immediately turn on their backs again, but otherwise gave no signs 
of life, even at the end of an hour's time. According to Dr. Hay, the newly hatched young, when teased, will undergo the same contortions, and will lie perfectly still on the back until they think they are unobserved when they will turn over and slyly creep away.

The favorite resort of the "spreading viper" is a sandy hillside with a southern exposure, or the borders of an open or cultivated field. In such a locality their principal food consists chiefly of noxious insects, and henee they, as well as all other harmless snakes, should merit the protection of man instead of being forever an especial target of his insane desire to kill all objects beneath him in the seale of life.

\section{TO A GARTER SNAKE.}

Thou art humble

And content to crawl

Upon the lap of earth:

To seek thy food without the brawl

And strife, which others,

Far above thee in the scale of life,

Do use.

Thou art harmless,

And yet upon thy head

Has ever been a curse unnerited;

Making of thee a shunned, polluted thing,

Although thou art possessed

Of neither fang nor sting.

And even now,

In this enlightened age,

Man sees thee but to spurn

And strike at thy poor form;

And on the printed page

Thy name is seldom uttered

Save with words of scorn. 


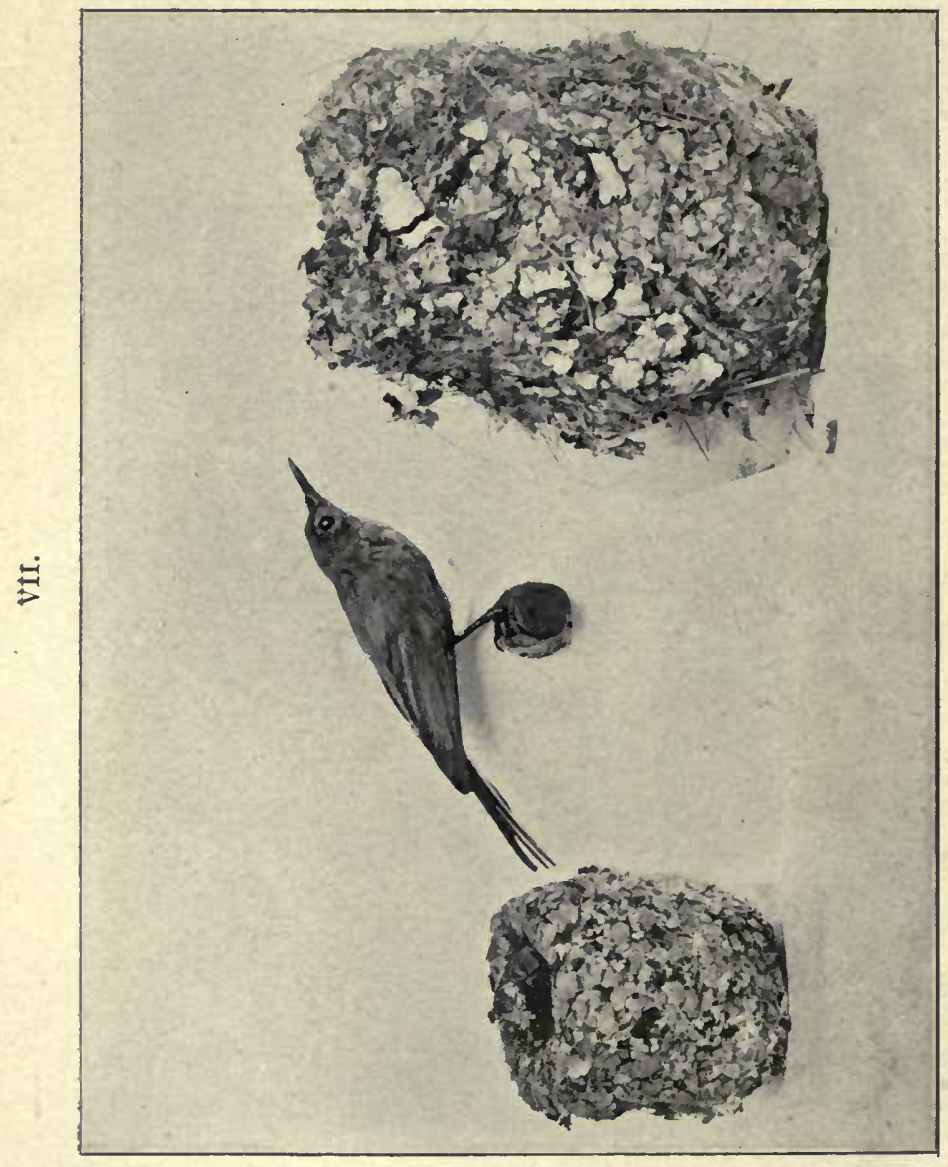

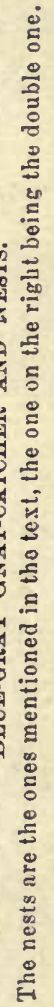




\section{A FEATHERED MIDGET AND ITS NEST.}

Next to the humming-bird, the blue-gray gnatcatcher, Polioptila ccerulea (L.), is the smallest bird nesting in Indiana. It is a summer resident, arriving from the south about the tenth of 'April ; the date of its arrival in Vigo County for five successive years having been April 10th, 11th, 11th, 10th and 10th, respectively, showing that it can judge the day of the year almost as well as some beings higher in the scale of animal life.

The total length of the bird is but $4 \frac{1}{2}$ inches, and of this, $2 \frac{1}{4}$ inches is tail. The color is an ashy blue, brightest on the head; the male with the forehead and a line over the eye, black.

By the time the gnat-catcher arrives, insects of various kinds are plentiful and its season's work of lessening their ranks at once begins. On April 18, 1897, I watched for an hour four of these birds in their ceaseless insect-seeking movements. They were in a thorn tree and $I$ in the angle of an old rail fence, less than a dozen feet away. Flitting from twig to twig; turning their heads now this way, now that; peering first on one side of a branch and then on the other, they kept up their eager quest. Every few moments one would dart out to one side of the tree and catch an insect on the wing. Once, while endeavoring to eatch a rapidly flying beetle, one of the feathered sprites 
turned a complete somersault in the air. Again, another flew close to the ground within a foot of my reclining form, eaught a small moth hovering above the grass, and then darting back to its perch gave the insect two or three whacks against a branch, either to kill it or to straighten it so that it could be easily swallowed, and then gulped it down.

One caught a moth as large as a cabbage butterfly, and struck it on a limb for several seconds. Four times the luckless insect got away but was each time recaptured in short order, and was finally, after repeated shakings and beatings, swallowed, wings and all-the bird stretching and gaping for some little time thereafter, much as does a hen which has swallowed a tight fit for her œesophagus. It seems, therefore, that if the insect be small it is swallowed as soon as eaught, often before the bird reaches its perch. If large, the beating on the limb or other resting place of the bird takes place.

When insect life, in and close about the thorn tree became, for a time, scarce, one or two of the birds would fly to the near-by fence and flitting along its angles would sometimes be rewarded by starting up an unlucky insect which would be instantly nabbed. Again returning to the thorn they would fly to a papaw, on whose large, velvety, expanding buds small bees and flies were plentiful; but the thorn seemed their favorite base of operations, and to it they invariably returned.

The long tail of the guat-eateher serves it admirably as a rudder, and in the stiff breeze which was blowing, was bent now this way, now that, to preserve 
the balance of the owner. The tail of the male bird is darker than that of the other sex. When in flight the feathers are spread out, the lateral ones showing pure white from beneath the blue-gray of the others.

Many other birds were seeking food in the shrubs and trees close by, but I doubt if any succeeded in finding as much as did the tiny gnat-eatchers. They were content with small fry, seeningly believing that " many a mickle makes a muckle." No insect of any size escaped their gaze. Gnats, mosquitoes, moths and flies were spied out a dozen, yes fifty, feet away, and with one straight dive and a click of the bill, the days of the insect were ended forever. The birds seldom missed their aim although in one instance one flew full seventy feet and eaught a flying form too small for me to see at that distance. The insects preyed upon must have been poor in nutrition or else the gnat-eatehers are veritable gourmands, for while I watched them each one caught, on an average, three to the minute, which would be 1,800 for a day of ten hours.

The usual alarm note, similar to that of the cat-bird but much softer, was not heard during the hour that the birds were observed. At intervals one would utter a faint chirp or chuckle, as if talking: to another. A low pit-ut-ut-e sound was also oceasionally made. Aceording to Coues, the gnat-eateher spends days in such incessant aetivity as that which I noted, "till other impulses are stimulated with the warmth of the advancing season, and the sharp accents of the voice are modulated into sweet and teniler song, so low as to be inaudible at any considerable distance, yet so 
faultlessly executed and so well sustained that the tiny musician may claim no mean rank in the feathered choir."

Each pair, after mating, seek some tree with a grayish bark, usually an oak, maple or apple, and finding a horizontal limb or eonvenient fork, they begin their nest, building it prineipally from hair and the fine fibres of various plants which they weave very elosely and compactly together. Finally they cover the whole with a coat of lichens, fastening them on with the finest of wool or the silk of spider's webs. This lichen eovering serves the useful purpose of a mask, rendering the eolor of the nest almost exactly that of the bark of the tree on which it is built; thus hiding it from the keen eye of the young oölogist walking beneath, or the keener eye of the crow or hawk flying above. But there is one eye sharp enough to detect it. For no matter how deep and dark the ravine in which a nest is hidden away; no matter what aid of nature has been called into use in rendering it inconspicnous to the view of other animals, necessity seems to lend a preternatural sharpness to the vision of the female cow-bird, enabling her to discover, whenever needed, a safe place of deposit for an egg, destined to become at no distant day an orphan which will be a heavy burden to its foster parents.

The nest of the blue-gray gnat-catcher when eompleted, is usually very small, and is cylindrical in form, not hemispherical, like that of most other birds. One which contained five eggs, taken on the 2nd of last May, was but $5 \frac{7}{8}$ inches in circumference by $2 \frac{3}{8}$ inches in length, and weighed only 3.7 grams. But the cow- 
bird cares nothing for the size or form of the chosen asylum for her young. If it is only large enough for one egg, it is sufficient for her wants, and she forthwith appropriates it to her use without even a "by your leave" to the rightful owners. And so, very often, among four or five delicate little gnat-catehers, there is found a large chuffy youngster, whose demand for food is incessant, and if supplied in sufficient quantity, he will in a day or two fill the entire nest,

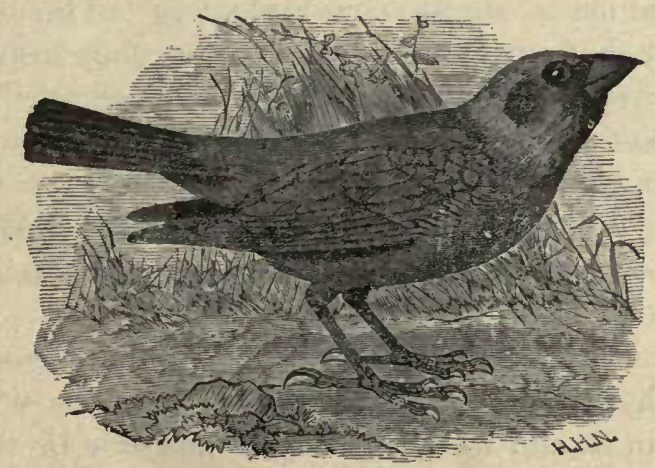

Fig. 20-Cow-bird.

and smother beneath his greater bulk the lives of the rightful occupants. It is one of those numerous cases of a struggle for existence in which the most overbearing, ugliest and strongest survives, instead of the fittest.

However, I suppose that the modern evolntionist would say, that in this case ugliness and brute strength are necessary qualities of the "fittest," and that nature has ordained that the cow-birds shall increase in num- 
bers as the millionaires of to-day grow in wealth, only at the expense of their weaker brethren.

But one-or rather two-eow-birds' eggs laid last season did not hatch, and it was of them that I started to write. On the 22nd of April, while out for a walk, I discovered a pair of gnat-eatchers building about thirty feet from the ground, in a maple tree. A week later, on passing near the spot, I saw that the nest had assumed massive proportions for one of that species, and on climbing up to investigate, found that it contained a single cow-bird's egg. The owners, however, had not deserted it, for they soon appeared, circling rapidly around, and uttering their shrill cries of distress. I left them immediately, merely supposing that they were young birds, not fully up to the times in nest building, and therefore had formed a large, loosely-constructed nest, instead of a small compact one, as is usually the case.

On the 5th of May I again visited the tree, and found that the birds had abandoned the nest withont laying in it, and were building a new one in the top of a tall oak a short distance away. Removing the old nest carefully, I earried it home in order to compare more elosely its size with the one taken a few days before. On measuring it carefully I found its cireumference to be $9 \frac{1}{2}$ inches; its length, $4 \frac{7}{8}$ inches; and its weight 12 grams, or about $3 \frac{1}{3}$ times that of the one first taken. Judge of my surprise when, on examining it thoroughly, I found that it was a double nest, or rather a "two story" one. The lower part, or first floor, was neatly and closely built, and in it was found a second cow-bird's egg. It had evidently 
been laid shortly before the nest had reached the usual size of such structures, and the builders, on discovering it, had immediately set to work and covered it entirely over, and then built up the sides of their house about $2 \frac{1}{2}$ inches higher. This upper portion was very loosely constructed, and had evidently been built in a hurry to meet the exigencies of the case. But, alas, for the expectations of our feathered friends! No sooner had the second floor neared completion than Mrs. Cow-bird paid them another visit, and left behind her a reminder in the shape of a new egg. This was too much for bird endurance. The gmatcatchers deserted in disgust the home over which they had spent so many anxions moments, and set to work to build a new one, in which, let us hope, they reared their little family unmolested by unwelcome guests. 


\section{MID-SUMMER ALONG THE OLD CANAL.}

Shady groves, green grass, wild flowers, and the sweet songs of our native birds in their chosen haunts -who in the hot and dusty days of mid-summer does not dream of such delights? True, parks there are, Collett's and Forest, easy of access both, and each with its own peeuliar charms, but for him who likes a degree of privacy the crowds which gather there with their bustle and noise savor too much of those to be seen daily on the streets of the city.

To many persons, and especially to any one interested in the objects and doings of nature, there cones at times an irresistible desire to leave, as far as possible, all signs of civilization; to phunge, as it were, into a wilderness and spend an hour, a day, or a week in solitude. To a resident of Terre Haute, one of the best and most accessible places for such a day's outing is along the old Wabash and Erie Canal between Conover's and the Five Mile Pond. True, it is not a wilderness, but there is many a shady nook and quiet. secluded spot where one may rest free from interruption and enjoy the pleasing odors of wild flowers and the songs of sweet singing birds. On a recent date, a day hot, sultry, and disagreeable in the impure air of the eity, I sought this favorite resort of mine, and it is of the birds I saw and heard, the flowers I met with, and a few of the thoughts which 
welled up and were snatched from oblivion by a ready pencil, that the present article has to do.

By street railway to Collett's Park, and then westward by the gravel pit road, one reaches the canal at one of its loveliest points near the southern edge of Conover's Pond. At the gravel pit I stopped awhile and saw the puny power of a single man gradually undoing what the mighty glaciers of the "Great Ice Age " had done long centuries ago. Pebbles of manifold kinds and sizes were being exposed once more to the sunlight after being hidden from it for-how many thousand years? The iron pick wielded by the workman pulled each from among its fellows and disturbed the quiet which had reigned with them since that former day when, after years of rolling, crushing, onward movement, they had been dropped, by the melting of a mighty bulk of ice, on the spot where they had since lain. And now they must be carried out to do duty for man; to receive the crushing effects of his wheels of iron, and, perhaps, by them be crumbled into dust after having successfully resisted the giant powers of the glaciers of long ago.

$\mathrm{Ah}$, the grandeur of the work which has been done by nature's forces in the past for the benefit of the races of the present! The sunlight of the old Carboniferous age did a work which now turns the wheels of industry throughout the world and the glaciers brought from afar the materials for our roadways and deposited them where they would be needed, yea, at the thresholds of our very doors.

Beyond the gravel pit, where in June glistened the waters of a broad, spreading pond, now gleamed in 
the August sunshine the golden yellow rays of the bur-marigold. Acre upon aere of them nodded to me from afar, while at my feet, on the roadside, their western cousin, the fetid marigold, made known its presenee, not so much by its rays, which are few and small, as by its disagreeable odor which is its most signifieant sign.

Down into the field of marigolds I took my way, desiring to meet them face to face and learn what they had to say of the summer's haps and mishaps. As seen from the brow of the hill all appeared to be marigolds, but when among them much of the yellow was found to be due to another handsome Compositæ with a homely name, the sneeze-weed. The land on which they grow was formerly cultivated but of late years has been overflowed in spring, the water standing on the ground each season until June. The owner, therefore, has turned the land over to these wild plants, and how they revel in their freedom! What a struggle among them for existence now that man's hand is not among their enemies!. Two species of marigolds, one devoid of ray flowers, the other with the showy golden-yellow rays; two of smartweed, one cocklebur, the sneeze-weed, and the fog-fruit, the last a handsome creeping member of the Verbena family-all growing in this damp rich soil in sueh luxuriance as to literally hide the surface of the earth from view. Which will be successful at the close of the struggle? Which, in five, ten, or fifty years, will be master of the soil? Perchance a stranger from some western plain or from one of Europe's vales will then have come and by its properties of prolificness 
and endurance have driven out these native plants and in the end become the victor of them all.

Much has been said and written about the beauty of the cardinal flower but not too much, for among all our wild plants which bloom from August to Oetober it ranks without a peer for brillianey of color and gracefulness of form. And so, when amidst the tall rank grasses near the margin of the pond I came suddenly upon several of them, their bright red pennons contrasted so vividly with the omnipresent yellow of the sneeze-weed and the marigold-their purity and beauty seemed so enhanced by their surroundings that I could but fall upon my knees and do them reverent homage.

Reaching at last the old tow-path of the canal I threw myself down in a shady bower and gave way to revery. The time was when the tandem mules by scores passed daily over the very spot where I now sat. Then, busy commerce reigned supreme and man, bowing to her imperious demands, carried by the produce of the world. Woolens and silks, lumber and iron, coffiee and teas, drugs and spices, indeed all the varied articles needed by a young and growing commonwealth, went up and down this artificial road of water.

Now, how changed! Commerce no longer, but nature reigns supreme. The tow-path is covered with the saplings of elm, ash, red-bud, and sycamore of fifteen to twenty year's growth. Wild birds of many species surrounded me on every side. From the topmost twig of a stately elm a southern mocking-bird sang for me a delightful medley of mimicry. It seemed as though a dozen different birds joined in the 
song; the notes of the cat-bird, jay and thrasher, chewink, pewee and robin, being each easily recognized as components of the medley.

As the clouds banked up in the west and north a turtle dove cooed softly above my head. A rain crow in a neighboring oak uttered his harsh refrain about the rain that was sure to come. Bob-white, in a stubble field on the hill above, whistled at intervals his

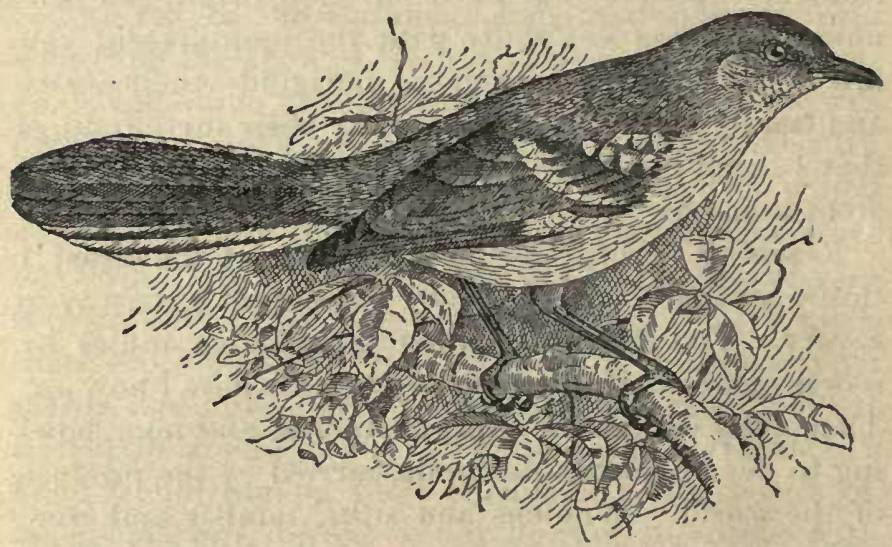

Fig.21-Southern Mocking-bird. (After Judd.)

summer note. A yellow-breasted chat in a near-by thorn tree scolded incessantly, as only a chat can scold, at my intrusion on his domain; while, blithest of all, was the song of the indigo-bunting and the merry warble of the vireos which were heard on every side.

Such sounds as these were uncommon here forty years ago. The silence of the treeless tow-path was then seldom broken except by the mule boy's "gree, ga-lang there," or "git "p, gol-dern ye." 
But the canal became too slow for our advaneing eivilization. The iron horse took the place of the mule. The engineer in blue jacket and overalls with smoke begrimed face and oily hands, that of the mule boy. The ungainly eanal boat with its snail-like pace has been succeeded by the "limited express," which follows not the winding course of a water pathway,

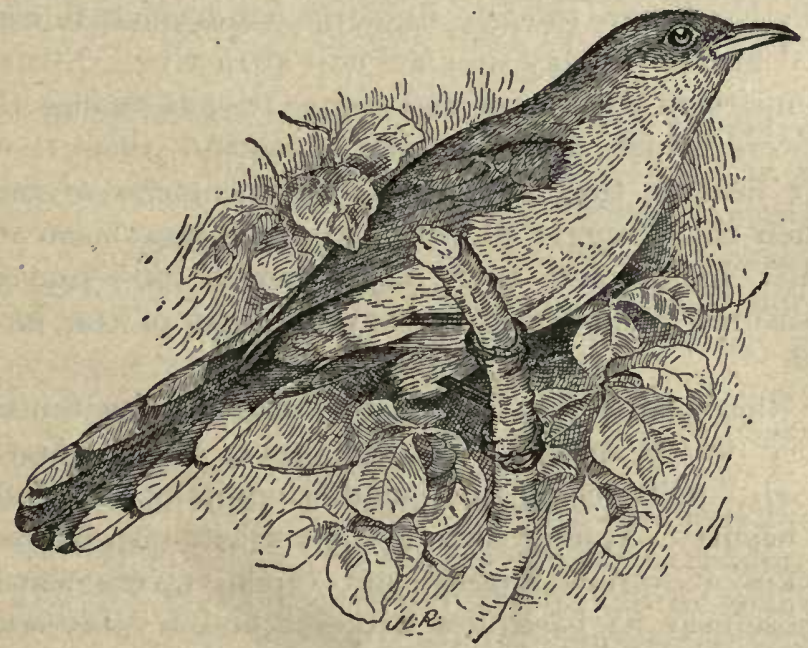

Fig.22-Rain Crow or Yellow-billed Cuekoo. (After Beal.)

but dashes onward over hill and mountain, through valley and plain, on a smooth and even steel track; while the "gee, whoa-haw" of the canal boy has given place to the shrill toot of the locomotive.

Many seeds of many weeds and old-fashioned Howers were scattered along the tow-path in those old days. Now their descendants are seen in many places, 
flourishing and blooming more.luxuriantly than if cultivated by the hand of man.

Ah, those "old fashioned" flowers, as we call them, how they bring up the memories of long ago! Of a country garden and door-yard where the "bouncing bets," "butter and eggs," "holly-hocks" and "larkspurs" gave forth their beauty and their odors to entrance our childish mind, and, in the innocence of childhood, were thought to be the handsoniest flowers that grew. To-day they are still attractive. Not by comparison with other and newer friends among the flowers which are far more beautiful than they; but because they ever recall the memories of yore when the struggle for our existence was borne by other hands and each day brought its round of pleasures unshadowed by any thought of the morrow.

Other plants there are in abundance along the old canal which man, in his ignorance, ealls "homely weeds," ne'er seeing their smaller points of usefulness or beanty. Among these is the mullein with its long spikes of yellow flowers and thick velvety leaves. Those near its base, now withered and dry, last winter foimed a beautiful rosette close to the ground and gave shelter and protection to many an insect both beneficial and injurious. Along waysides and the borders of barren fields the mullein has its favorite home. Ever an evidence of the presence of man, today it finds a congenial lurking place along the pathway of his former road of water.

Milkweeds; ton, flourish there in great profusion and often reach a height of six feet or more. Their hand- 
some umbels of purple flowers are very attractive but prove a veritable death trap to many a bee and unwary insect which visits them in search of honey. For the pollen of each flower, instead of being in numerous small grains, as is usual in other plants, is massed into a few waxy and adhesive bunches; and is so arranged that when an insect touches a certain point the pollen mass moves suddenly upward and clings by a slender stalk to the leg of the visitor.

If, as sometimes happens, a mass adheres to each of three or four of its legs the nuhappy insect is so encumbered that it cannot move and so remains a prisoner until death. Almost every insect which leaves a bunch of milkweed flowers earries away one or more of the waxen masses, and as it goes immediately to an adjacent buneh, cross fertilization is thus more readily and surely aceomplished than by ordinary nethorls of pollen distribution.

Queen of all our creeping or trailing shrubs is the trumpet creeper with its large pinnate leaves rivaling the emerald in their shade of green, and its giant trumpet-like flowers so attractive to humming bird and humble-bee. Mid-summer is the time, and the banks of the old canal the place, to see this creeper in ail its primitive beauty. There the soil is congenial and bush and shrub furnish a ready support to which its aërial rootlets freely cling, thus forming many a snug retreat in which the nest of. woodland songster is securely hidden.

Numerous other wild flowers, many of which are as deserving of praise as those above mentioned, are 
now blooming along the old canal; for at this season its banks

"Are gay with golden rod,

There blooming grasses nod,

And sunflowers small and yellow turn ever to the sun;

Quaint darky-heads are there,

And daisies wild and fair,

In everybody's garden each flower's the loveliest one."

Space forbids the detailed mention of others. Go, $\mathrm{my}$ reader, and see them for yourself. The flowers and birds and bugs are there, and one has but to open eye and ear to see and hear them. One warning, however, before you go. - The only way to thoroughly enjoy and be benefited by any outing is to leave all business cares and responsibilities behind. Think not for a single moment of the time lost, the dollars slipping away during the absence from the store, the office or the shop. For the time being let "by-gones be by-gones" and "to-comes be to-comes." Yield only to the pleasures of the present. Dream only of the duties of the day. Strive to gain rest, knowledge and inspiration from the objects met with, and enjoyment and benefits, not to be measured by dimes or dollars, will be yours. 


\section{THE IRON-WEED.}

Belonging to the great Compositce family of plants are many of our worst weeds, such as the rag-weed, horse-weed, white-top, thistle, burdock, and last but not least, that scourge of our blue-grass pasturesthe iron-weed. The name, Composito, is given to the fanily from the fact that its members have their small, yet perfeet flowers densely crowded together into a head, which is enclosed by an involuere or eup formed of several circles of modified leaves called "bracts"; this involucre performing the same protective function for the compound mass that the calyx or outer green envelope does for the ordinary separate flowers of other families. The object of this massing together of a great number of small flowers into a large head is that they may more easily and certainly attract the attention of insects and thus secure their fertilization. Taken singly, the flowers are too small and in'conspicuous to attract separate attention, but by huddling themselves together into a showy mass they have proven themselves very successful plants; so much so, indeed, that the family is now the largest known in the vegetable world.

Many of the Compositre, as the sunflowers and asters, have the onter flowers of the head enlarged into the so-called "rays," thus increasing their showiness, while 
those which have no rays, but which have all the flowers of the head alike, are said to be "discoid."

Pre-eminent among the latter group, on account of their size, abundance and hardiness, are the plants known as jron-weeds-two speeies of which-Vernomia fasciculata Mich., and Vernonia noveboracensis (L.),

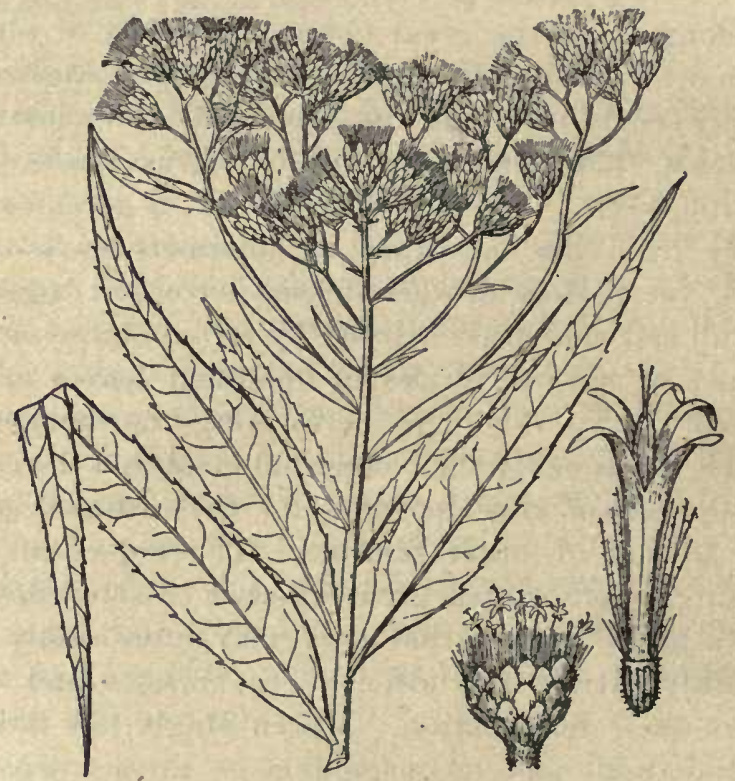

Fig. 23-Iron-weed. (After Britton.)

are found in Indiana. However, the two are so nearly alike that none but the praetical botanist can distinguish them, and hence they will be spoken of in this connection as one.

In the latter part of August, 1887, I spent a day in a large woodland pasture in central Indiana. The 
effects of the noted drought of that season were then visible in all directions. Vegetation every-where was dying or dead. All nature had put on an unwonted garb whose prevailing eolor was brown. The grass of the meadow had been eured into hay before it was eut. The leaves of the maple and beech were shriveled and dying. No blue lobelias greeted, as in Augusts gone by, my wandering footsteps. No eardinal flowers waved their red pennons above the sedges of the swamp, for both swamp and sedges were things of the past. Only the eoarse iron-weed with its cyme of purple flowers seemed to be flourishing in the parched, dry soil; holding its own where all else was perishing-thus proving itself well worthy its nametough and indestructible as iron.

In the great contest for supremacy forever going on among all plants as well as among all animals, the rag-weed, fox-tail, white-top, etc., go down before the ereeping, smothering power of the Kentucky bluegrass; but this rough, ungainly weed ne'er gives up the struggle, and in many places grows as rankly in the farmer's best lowland pastures as does its cousin, the greater rag-weed or horse-weed, along the margins of his cultivated bottom fields. It is seemingly becoming more abundant each year, and at present is undoubtedly the worst weed with which the stock farmers of Indiana have to contend. Let us note briefly some of the characters which render it so tenacious of life and so difficult of extermination.

Its perennial roots are stout and fibrous, and each autumn are filled with a sufficient supply of nourishment to give the stalk of the ensuing year a good 
start in life. They radiate in all directions from the base of the stem, spreading over an area of several square yards and penetrating the soil in search of moisture to such a depth as to render abortive any attempt of man to pull the plant up bodily, roots and all. In rich soil the stem grows to a height of six to eight feet and is leafy to the top. The leaves are linear to lanceolate-oblong in shape, sbarply toothed, and so innutritious that none of the higher animals, not even the sheep, will feed upon them.

The only insect encmies of the plant, so far as noticed, are the black blister beetle which attacks the leaves when other food is scarce, and a small gall fly whose larvæ feed upon the juices of the flowering branches.

Many species of bumble-bees and butterflies visit its blossoms in search of nectar and pollen, and thus aid materially in their fertilization. The flowers in each head number, on an average, twenty-five, each of which produces a single seed. On one speeimen of medium size were counted 743 heads, so that 18,575 seeds, each capable of becoming a fully developed iron-weed, were borne by that plant alone, and the majority produce as many, or more. To secure a broad dissemination each of these seeds bears at maturity a tuft of light brown bristles known as the pappus, and by its aid the seed may be wafted by the wind miles away from the parent plant. Again, as the iron-weed grows in greatest luxuriance in the lowland pastures near small streams, many of the sceds fall upon the water and are borne onward till they lodge against some bank or are buried in the sediment deposited by an overflow; places well suited for their 
future growth. In these ways the weed is continually spreading into pastures which heretofore have been entirely free from it. Taking into consideration that it is a native plant, and therefore well suited to our soil; the character of its roots; the immense number of seeds produced; the modes of their dissemination, and its almost total exemption from the attacks of injurious insects, it is no wonder that it is so well able, not only to hold its own in the struggle for existence, but also to increase in numbers from year to year.

As to the methods of extermination, many have been tried, but, too often, in vain. One which can be relied upon, but which in many cases is impracticable, and moreover is fatal to the pasture as well as to the iron-weed, is cultivation of the soil. Continued stirring among its roots the plant cannot withstand and so soon succumbs before the onslaught of the plow and the hoe. Many persons believe that cutting the weed during the flowering season will destroy it, but they have their labor for their pains, its roots being perennial, and the plant being, therefore, not dependent upon the seed to carry it over the winter. One farmer assured me that he had mowed the iron-weeds from his pasture every Angust for 17 years, and that they were still as abundant as ever. Another, after mowing for years, went to work and grubbed them out, but failed, of course, to remove all the pieces of roots from the ground and the crop of the next season was not appreciably diminished. A third has very nearly solved the problem of their extermination, and it is to - his experience that I wish to call especial attention. 
He has a pasture of 80 acres, and at present it takes but two hours' mowing, twice or three times a year, to rid it of the weed; whereas, just across the way. is a pasture where it holds undisputed sway from May to August.

This third farmer had studied botany and knew that all plants have their food assimilated, that is, fitted for their use, in their leaves. The crude food materials, carbon-dioxide, water, and various nitrates and other salts in a soluble form, are gathered from the air and the earth by the leaves and roots; but in the leaves alone these materials undergo certain chemical changes and are transformed into starch and other foods which can be used directly by the plant in its growth. Any excess, not needed for growtl, is stored up in the seeds, buds, under-ground stems and roots, for the purpose of furnishing the young plant or the growing shoot suficient nourishment to live upon while it is developing leaves which in time will gather and assimilate a new supply of food.

This farmer, knowing all these facts, reasoned that if he eut his iron-weeds in May, again in June, and still a third time in July, the perennial roots would not be filled with nourishment at the end of the season, as their extra supply would be needed to start new shoots each time the old ones were destroyed. Moreover, the leaves wonld not have time sufficient to produce much excess of food to be stored up in the roots, as all their powers would be taxed to furnish food for the rapid growth neeessary for the new shoot to arrive at maturity before the season was over. He proceeded to act upon his conclusions with the above 
mentioned result. The perennial roots of the old weeds weakened and in time died, and the only ones which he now has to keep down are those which each year spring from seed grown in other places. The work of mowing the weeds three or four times a year, at first a difficult one, gradually became less and his pasture was in time almost redeemed from the scourge which had rendered it comparatively worthless. On the other hand his neighbor, who lets the weeds grow until August and store up a good supply of nourishment in the roots, not only loses the summer's pasture but retains the weeds from year to year.

It has been said that all things in nature have their use-that nothing exists but for a purpose. It is the work of science to discover and make known the use of nature's objects; and day by day her secrets are gradually being exposed, thereby advaneing man in civilization, by enabling him to better control the ravages of those existing forms which are injurious to his interests. If, however, the iron-weed has a use, other than that shown in the beauty of its flowers, no one has yet discovered it. But there is time; for of the thousands of plant forms which exist, we know the uses of only a few, as corn and hemp, ginseng and blood-root. Let us hope that some valuable medicinal or other property will soon be discovered in the ironweed and a reason for its existence thereby pointed out to the doubting humanity of the present.

Meanwhile the naturalist will go on admiring the beauty of its bloom; for however coarse and repulsive the stem and leaves may appear, yet each head, with its 25 or 30 dainty florets so prettily grouped within 
their protective cup, reveals a striking beauty to the true lover of nature. And when in the glamour of an August morn he stands upon a hillside and views acre upon acre of the broad purple cymes waving in the valley beneath, all memories of the plant as a pernicious weed are blotted from his mind by the attractiveness of the scene before him. 
VIII.

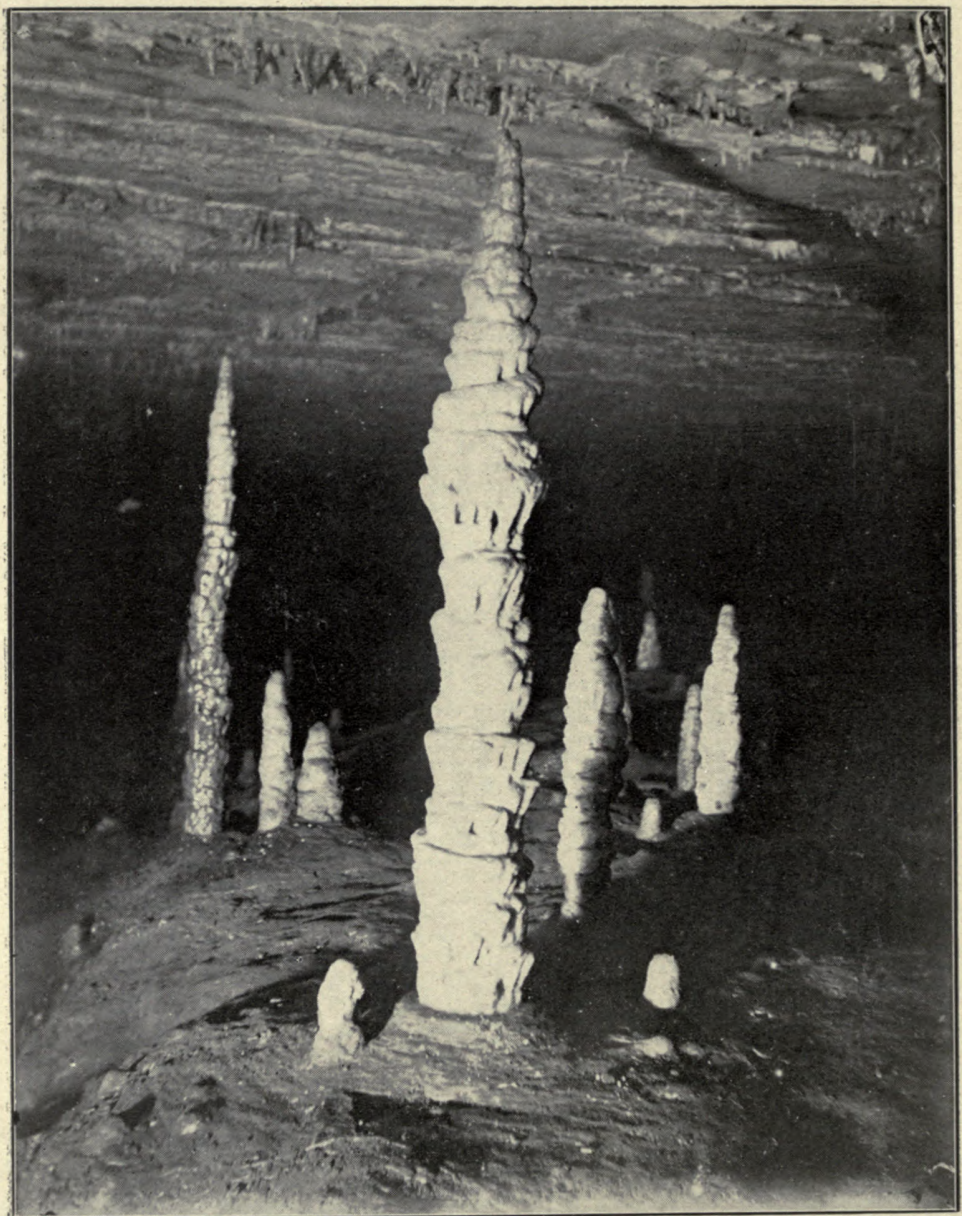

Washington's Monument, Marengo Cave. (See page 133.) 


\section{TEN INDIANA CAVES AND THE ANIMALS WHICH INHABIT THEM.}

Caves are uncanny places. So thinks the average person, when, for the first time, he stands in the entrance of one of these under-ground cavities and glanees along its walls of stone until his gaze reaches the point where the shadowy rays grow din and eternal darkness begins. The chilly current of air which comes rushing forth, and the solemn silence of the depths beyond, beget a sensation of awe which it is difficult to suppress. Only a long experience in traversing subterranean passages will accustom a person to their surroundings and enable him to enter a cavern with anything like that degree of indifference with which he passes from daylight into the darkened rooms of a dwelling.

In the mind of the naturalist who is a tyro in cave exploration, there is mingled with this feeling of awe one of great expectancy. He hopes to add some new and wonderful facts to his store of knowledge. Another world is to be opened up before him. He is to travel through passageways worn in solid stone by the slow eroding power of water. He is to see in actual process of formation those pendent stalactites of creamy, crystalline calcite of which he has often read. He is to meet for the first time whole races of 
animals bereft of the sense of sight. To him, therefore, the under-ground journey promises much more than to the ordinary observer who makes it mainly for the novelty and the scenery which it affords.

The Sub-carboniferous Limestone area of southern Indiana contains many sink-holes and caves within its bounds. This area is, for the most part, embraced in the counties of Owen, Monroe, Lawrence, Washington, Orange, Harrison and Crawford. Going southward from the center of the State, the sinkholes first become a prominent feature of the surface in eastern Owen and western Morgan counties, and are found in numbers thereafter, in the area mentioned, until the Ohio River is reached, beyond which, in Kentucky, they are said to be still more numerous, in

Sink=holes. many portions of that State averaging 100 to the square mile. These sinkholes vary much in size, sometimes being but a rod or two across, and again embracing several acres in extent. 'I'hey are, for the most part, inverted cones or funnel-shaped cavities, and, where small, usually have the sides covered with a matted growth of vines and shrubs. Where larger, trees of varying size are often found growing from the scanty soil on the sides or from the bottom of the sink. If one will examine closely the lowest point of a sink-hole, he will usually find a crevice or fissure through the limestone, or sometimes a large opening which, if it be possible to enter, will be found to lead to an under-ground cavity -a cave.

Both sink-holes and caves not only owe their origin, but usually their entire formation, to the slow, unceas- 
ing action of rain or carbonated water upon the limestone strata in which they occur.

Carbon dioxide is present everywhere in the atmosphere, constituting about three parts in 10,000 of the volume thereof. The condensed vapors, falling as rain, unite with a portion of this carbon dioxide, and form a weak carbonic acid or rain-water. Wherever this comes in contact with limestone,

Formation of Sink-holes and Caves. it brings about a chemical change. By this change the limestone is dissolved and carried onward with the seeping or flowing waters.

In the beginning of a sink-hole, the rain-water seeps through a crevice or joint of the limestone to a lower stratum, along the surface of which it finds a passage. By gradually dissolving the stone, this passage-way becomes increased, until finally a large cavity is formed inmediately below the surface. The unsupported weight of the latter causes it to gradually sink downward and assume the inverted cone shape above mentioned. The opening at the bottom becomes larger, allows more water to enter, and a more rapid dissolving takes place between the layers. As soon as the under-ground passage has become large enough to allow a good-sized stream to enter, the process of erosion or abrasion is added to that of the solvent action of the water and the enlargement of the passage goes on much more rapidly. This gradual enlargement continues for hundreds, perhaps thousands, of years and results in a cave, varying in size according to its age, the amount of water flowing through it and the softness of the rock dissolved or 
eroded. The larger caves possess great vaulted rooms, deep pits, high water-falls and streams of water; some of the streams being large enough to allow the ready passage of a good-sized boat.

From the above it will be seen that sink-holes and caves are closely related, the latter, in fact, being largely dependent upon the funnel shape of the former to collect the surface waters and direct the flow thereof. A number of sink-holes often connect by narrow and tortuous channels with the same underground passage, the latter increasing in size with the addition of each new branch, until finally it attains majestic dimensions.

The rooms and passages of limestone caverns are often, after their formation, partially filled by those handsome forms of crystalline limestone, called stalactites and stalagnites. These are seldom, if ever, formed in great numbers, except where the passages or rooms are close to the surface. The water, charged with carbonic acid, filters slowly through the soil, and, entering the narrow crevices and joints between the layers of stone, seeps downward until it pierces the roof of an under-ground eavity. Here the slowly dripping water comes in contact with

Formation of Stalactites and Stalagmites. the air of the eave. The liquid is evaporated and the solid particles of carbonate of lime, dissolved from the rocks with which it had come in contact, are left behind. Each successive drop thus deposits or leaves a solid particle, until finally a pendent cylindrical mass, called a stalactite, and resembling in general form an icicle, remains suspended from the roof. 
Where the water, thus oozing through the roof of a eavern, is greater in quantity than can evaporate before it falls, it drops from the stalactite to the floo: below. There it splashes outward and in time evaporates, leaving the solid particles brought down. These accumulate one on top of another until finally a cylindrical or cone-shaped mass protrudes upward, slowly growing in size, each successive layer being distinct from the preceding. This upward rising mass is a stalagmite. It is almost always greater in drameter than the stalactite above it. Often the two, in time, meet and a column, or stalacto-stalagmite, of crystalline limestone results. Down the sides of this

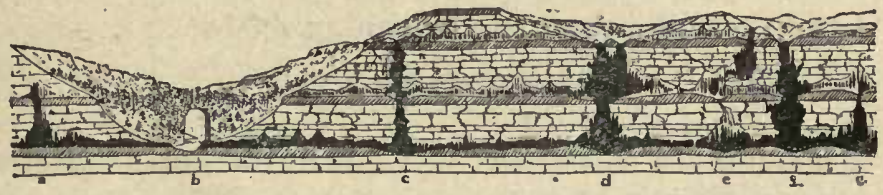

Fig. 24-Showing the formation of caverns in limestone.

$s$, Sink-hole; $a, c, d, f, g$, rooms in cavern; $b$, natural bridge, formed by the sinking of the roof of a former very large room; $e$, passages, showing numerous stalactites.

(After Shaler.)

the incoming waters slowly flow instead of drop; evaporating and leaving their solid particles as they move, thus increasing in size the diameter of the column. If this action continues long enough, the whole passage or room may be filled by these deposits and all semblance of a cave obliterated.

It will thus be seen that water, where it flows freely and rapidly through massive beds of limestone, dissolves and erodes great cavities therein; where it seeps and oozes through such beds it tends to fill up 
the cavities already formed. Where the slowly flowing water has passed through large masses of pure crystalline limestone, the resulting stalactites and stalagmites are often very elear, almost translucent. Where sediment and mud is carried down with the earbonate of lime the resulting formations assume a dirty brown and unattractive appearance.

Many small eaves, and doubtless some large ones, exist in southern Indiana whose presence is, as yet, unknown. In searching for them the bottom of a sink-hole will be the best starting point, the only thing necessary being to blast or dig out the cavity commonly found there, until it becomes large enough to allow a person to enter.

\section{PORTER'S CAVE.}

The mouth of Porter's Cave is in the north-eastern corner of Owen County, very elose to the line between Owen and Morgan counties, and the source of the stream which flows therefrom is distant about onehalf mile to the north-eastward. The cave is little more than a narrow, water-worn passage-way through the rocks, which at this point consist of St. Louis and Keokuk limestones, the former comprising the roof and the latter the floor.

The mouth of this cave is the most beautiful of any visited in the State. It is in the side of a hill at the head of a narrow canyon or guleh, which has been eroded by the stream which flows from the cavern. From the floor of the cave to the bottom of this gulch the distance is 33 feet, down which the stream flows 
in a perpendicular water-fall. The mouth of the cave is fifty feet wide and $14 \frac{1}{2}$ feet high, the roof extending out in a broadly arched front several feet beyond the the face of the water-fall below. The rock down which the water flows is covered with moss, and in the early morn, when the sunbeams light up the interior of the cave for a distance of 75 or more feet, and glisten and sparkle from the mossy background of the falling water, the scene is a most entrancing one.

The cave can be entered only by a narrow footpath on the northern side of the mouth. Twenty feet back from the entrance the roof becomes flat; and for almost 100 feet is comparatively smooth, being composed, apparently of one immense slab of limestone. In this distance the width gradually narrows to 30 feet. The floor is wholly of rock, in some places covered to a depth of several inches with sediment and loose stones brought down by the running stream. The latter, for the first 270 feet, is from four to eight feet wide and two to five inches deep. It meanders from side to side of the floor, making the frequent crossing of it a necessity. Beyond 270 feet it covers the entire floor to a depth of from six to twenty inches, and farther exploration must be made while wåding.

The cave salamander, Spelerpes maculicaudus (Cope), inhabits this cave, several specimens being found within 200 feet of the entrance. They were clinging to the damp walls and showed little fear when approached. The raccoon, Procyon lotor (L.), visits the cave in numbers and evidently passes entirely through it, as was evinced by the tracks, which were very plentiful along the margins of the 
stream. To their visitation is probably due the absence of crayfish and other crustaceans, no specimens of which were noted. Four kinds of cave flies were found on the walls from seventy-five feet on back as far as exploration was made. A few cave myriapods dwelt beneath stones within 150 feet of the entrance, and three kinds of spiders were taken from the floor or ceiling. One of these, Theridium porteri Banks, had not before been described. It was found on the walls or roof of the room at the source of the cave, and near each specimen was often two and always one small globular cocoon, suspended by a single thread from the roof or a projection of the wall. Scattered threads of webs were also noted, but ran in no definite direction.

But few stalactites occur in Porter's Cave and they are dirty brown in color. At a point 250 feet from the entrance a very large one partially shuts off the passage-way; and 645 feet in, a similar one which has had its lower portion broken off, is found. At 750 feet the roof becomes so low that one has to stoop, and the width is reduced to 18 feet. From this point onward both height and width gradually diminish until at 852 feet it became necessary to crawl through water, and further exploration was abandoned. It is claimed that in a dry season persons have passed entirely through the passage, crawling for several hundred feet and then emerging into a low room near the source. A visit to the latter showed that it was not a true sink-hole, but a passage-way worn through the rocks in the side of a low hill. The opening was ten feet wide and about four feet high and a short distance 
back expanded to twenty-five feet in width, but soon narrowed again to eight feet, and $\mathbf{1 5 0}$ feet from the entrance the roof came down close to the water and stopped farther progress. Except to the naturalist there is little attraction about Porter's Cave other than its mouth; but that alone is well worthy a visit by all who enjoy the picturesque and beautiful in nature.

\section{COON CAVE.}

This cave is located in the south-western part of Monroe County, about eight miles from Bloomington, the county seat. The entrance is a perpendicular pit or well, forty-six feet deep and about-six feet in diameter. The top of this pit is at the bottom of a rather shallow sink-hole and the descent into the cave was made by a rude ladder which had been constructed of poles by some previous explorer. At the bottom of the pit one finds himself on the edge of a passageway, about ten feet high and nine feet wide, which extends both to the right and the left. The right hand passage is but about ninety feet long, the roof and floor gradually converging and being but a foot or so apart at that distance. Thirty-five feet from the entrance is a hole in the floor of this right hand passage, through which one can be lowered by a rope fifteen feet to the floor of a lower passage, twenty-five feet long, ten feet high and six feet wide, which extends nearly parallel to the passage above. By the side of a smaller opening is a stalactite, seven feet six inches long and five feet five inches in circumference, 
suspended from the bottom of the upper floor into the passage-way beneath.

The left hand passage comprises the greater portion of the cave. It varies in height from four to twenty feet, averaging about eight. But little stooping or crawling is neeessary, but much climbing over rough stones and up and down steep, rugged slopes has to be done, the floor in most places being eovered with great masses of fallen rock. Two hundred and forty feet from the entrance a erevice leads off' through the walls on the right. By crawling along a ledge of projecting stone for about 100 feet, we reached the edge of an opening large enough to admit the body of a man, and by the aid of a sapling, bearing numerous short prongs or remains of limbs, which we found in place, we descended twenty-eight feet into a lower passage, about sixty feet long and ten feet wide. Here we found some shallow pools of water, but no living forms, and nothing in the way of seenery to reward us for the labor of getting down and up.

In numerous places the floor of the main passage has a deep cleft near its center or on one side, varying in depth from eight to twenty feet, and in width from a few inches to three feet and more. In several other places, notably 340 feet from the entrance, are openings or deep pit-holes, similar to those already mentioned, leading down into lower passages, the latter, however, of small extent. The main passage begins to narrow about 575 feet from the entrance, and 100 feet farther on is but three feet wide. At this point a branch turns to the left and leads downward into a lower room of small size. A short distanee beyond 
this branch the main eave ends in a small erescentshaped room, in the farther end of which, 750 feet from the entrance, is a deep erevice in the floor, filled with water of exceeding clearness. This pool of water was four feet wide and appeared but three or four feet deep, but actual measurement showed it to be nine feet, three inches in depth. The length of the pool could not be determined, but it extended down a branch passage to the right, covering all the floor thereof as far as one could see. For two or three feet above the water-line the walls of this room are covered with s mall but. most beautiful erystals of caleite,

\section{MAP or COON CAVE.} Menroe County, ind.

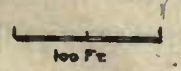

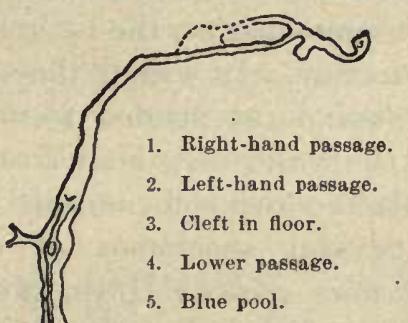

5. Blue pool.

1. Right-hand passage

passage.

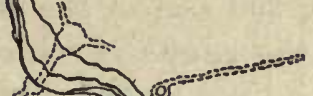

Fig. 25.

which reflected the light of our candles in a most brilliant manner. Numerous small stalactites of the clearest crystal stud the walls and project from the crevices of the roof, while the floor is largely composed of ealcite, derived from the overflow and subsequent evaporation of the water from the pool. This 
room is, in truth, a fairy grotto, decked with jewels resplendent, and a view of it will well repay for all the time and toil necessary to step within its bounds.

Animal life was represented by but few forms in Coon Cave. Several bats were found hanging, head downward, from the roof, but all were of the single common species, the little brown bat, Vespertilio subulatus Say. In winter they are found in the cave by thousands, suspended from the roof and projections of the walls, their bodies remaining in a state of comparative torpor for months in succession.

Several specimens of a cave-inhabiting beetle, Quedius spelaus Horn, were found beneath stones within 300 feet of the entrance. This is a twilight form, the adults of which are not wholly blind, and usually lives in the dim light near the entrances of caves, feeding upon the excrement or decaying remains of such animals as frequent the place. A few flies were found on the walls and near them two kinds of spiders were taken-showing that here, as elsewhere, the fly is followed by the spider, with the ever ready invitation "to walk into his parlor."

By far the most common form of life in this, as in many other of the caves visited, was a small whitish insect, Degeeria cavernarum Pack., about one-eighth of an inch in length and belonging The Cave to the order Thysanura. Like most other cave-inhabiting insects, it occurs only in comparatively moist places, often swarming by thousands beneath or on the surface of damp rocks, especially where organic matter, such as the remains of lunches, drippings of candles, decaying 
wood, etc., is scattered. It has the power of leaping several inches by means of a long, spring-like appendage bent under the hind body, which on being released throws the owner high in the air. The motion thus produced may be likened to that effected by a spring-board. These little acrobats, however, carry their spring-boards with them wherever they go and hence have come to be. known by the common name of "spring-tails." The one under consideration doubtless forms much of the food of the small spiders, harvestmen and beetles which frequent the floors of the caves.

\section{ELLER'S CAVE.}

The entrance of this cave is at the bottom of a sinkhole, 100 feet in diameter, which is located in a woods about five miles south-west of Bloomington, Monroe Comnty. The cave itself is a double floored one, the upper and older floor being dry, and the more recent and lower floor having a stream of water flowing through the greater part of its length.

The entrance, about six feet wide and six and a half high, descends gradually for about fifty feet, and there expands into a room twenty feet wide, thirty feet long and twenty-five feet high, which scrves as a vestibule or starting point for both floors, the entrance to the upper one being in the wall, about eight feet above the floor of the common entrance.

Two passages lead from this vestibule to the lower floor, one to the right through a narrow winding cleft in the rock, and then down to the bed of a stream, along which, by crawling, one can advance until he 
comes out into the second passage, fifty feet from its starting point. From here onward for 210 feet the lower passage leads through a water-worn crevice from two to four feet wide and three to tifteen feet high, the stream sometimes covering its bottom, and again rumning in a channel cut beneath one or the other of the sides.

In this stream were found two species of small crustaceans. One was a.

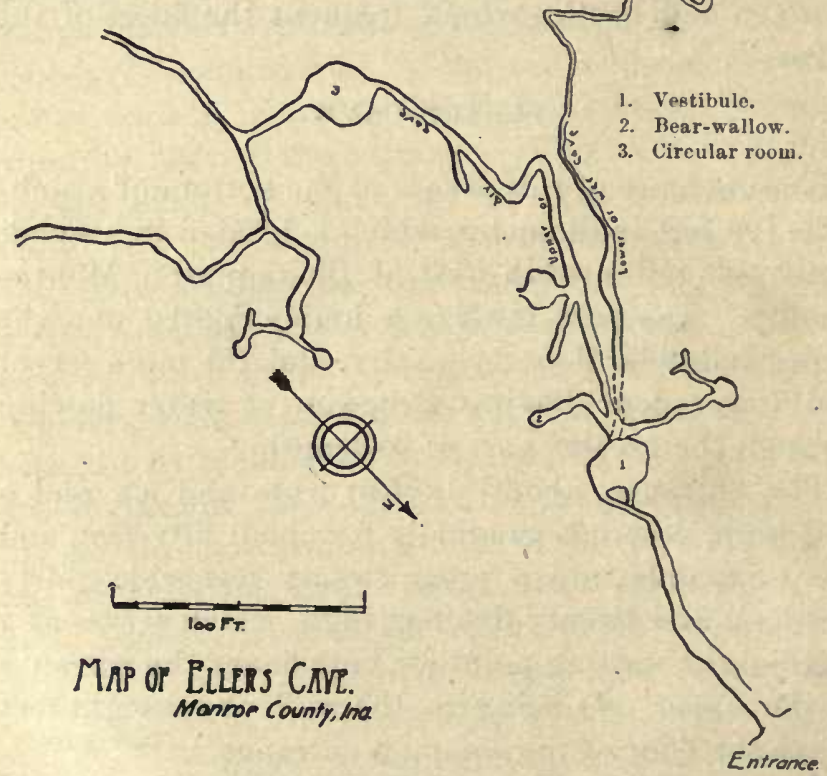

Fig. 26.

shrimp, Crangonyx gracilis Smith, three-fourths of an inch or less in length, which is often found in wells and springs in central Indiana, and had probably been 
washed into this and other caves in which it was found by the heavy rains of the season. The other and smaller species, Cocidotaca stygia Packard, is a truc subterranean form and was the most common crustacean noted in Indiana caves. It was usually found singly, swimming or crawling slowly through the

A Cave

Crustacean. water of small cave streams, and was easily picked up with a pair of forceps. Its body is flattish like that of a sowbug, but is oblong and more slender, reaching a length of one-third of an inch. These crustaccans probably furnish much of the food for the blind fish and crayfish which often inhabit the same streams with them.

Three hundred feet from the cave entrance the lower passage ends abruptly in a room fifty. feet high and ten feet wide, the sides converging in an angle to form the roof. On the left, about twelve feet from the floor, is an arched opening,

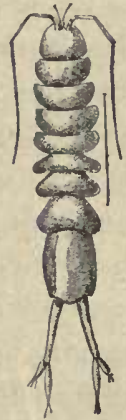

Fig. 27-Crecidotrea stygia. and through it comes a roaring sound of falling water. With difficulty one climbs a slippery bank and, passing through this opening, finds a most magnificent scene for so small a cave-a great cylindical pit or shaft, twenty feet in diameter and sixty feet high, down which, on the farther side, falls a stream of water. A large bowl-shaped eavity, twelve feet deep, has been worn by the falling water in the limestone below the level at which the pit is entered. Descending into this, it was found that the stream flows out through a passage to the left too low for exploration. 
Returning to the vestibule we elimbed to the entrance of the upper floor, and, passing a short distance within it, found two passages diverging. One to the left, but forty feet in length, ends blindly against a bank of hard clay. Here had been, in days of yore, a bear-wallow and the marks of bruin's elaws were numerous and plainly visible in the clayey walls. The right hand passage proved a long and tortuous one and had a number of short branches leading from it, one of which showed plainly the evidence of former inhabitancy by bears. This main upper passage is in most places seven to ten feet high, with a width of five to seven feet. Two hundred feet froin the restibule it became necessary to crawl for about thirty feet throngh a space one foot high by two feet wide, when we emerged into a circular room thirty feet in diameter by three and a half high, the floor of which contains a vast amount of bat griano. Beyond this the passage forks into three branches, each of which was explored as far as possible, the longer one reaching 400 feet from the vestibule before its small size barred further progress. The floor of this upper cave was covered in many places with a yellow ochery clay. In this, in several places, were found some handsome acicular erystals of selenite. No water was found on the upper floor, except at the farther end of the galleries, where it stood in shallow pools. These were evidently quite near the outer surface, as the shells of several land snails were found near by the water. 


\section{SHILOH CAVE.}

The entrance to this cave is at the bottom of a sinkhole a few rods north of Shiloh Church and about seven miles north-west of Bedford, Lawrence County. Except after a heavy rain, no water flows through the entrance, but a stream runs the entire length of the main eave, entering it from beneath a great mass of fallen rock which has partially closed the entrance, and meandering from side to side on the floor in its onward course. On entering, one deseends rapidly for about twenty feet, and then reaches the general level of the main passage. This passage is from fifteen to twenty-five feet high and about the same width for 2,000 feet, which was as far as it was explored, the water becoming too deep to wade beyond that point. It far exceeded any of the previous caves visited in the number and size of its stalactites and stalagmites, many of which were of exceeding clearnass. In the words of Prof. John Collett, who visited the cave in 187:3: "The lofty sides are draped and festooned with stalactites, sometimes hanging in graceful folds, or ribbed with giant corrugations. Above, the roof and overhanging sides bristle with quill-like tubes, fragile as glass, each tipped with a drop of water which sparkles in the lamplight like a crystal jewel."

Three hundred feet from the entrance three jets of water pour down from the right wall of the cave and add to the size of the stream along its floor. These falls vary in height from seven to ten feet, and to- 
gether they produce a roaring sound which is echoed far along the main passage-way.

From this point onward the walls are dripping more or less and are fringed with small stalactites. About 900 feet from the entrance are two large stalagmites, one of which, named by Collett "The Image of the Manitou," has been broken. Originally it must have been six feet in beight and eighteen inches in diameter.

In a pool of the stream in the main passage were secured two of the small aquatic insects known as "water boatmen." They belong to the order Hemip. tera, and to the genus Corisa, and were the only "true bugs" taken in Indiana caves. They were probably accidental visitors, since their compound eyes were fairly well developed.

In the same pool were numerous specimens of the blind erayfish, Cembarus pellucidus (Tellkampf). This curious crustacean was found in a number of other Indiana caves, and probably inhabits every one in which there is a permanent water supply. Careful exami-

The Blind

Crayfish. nation of cave bed streams ought, also, to show its oceasional oceurrence outside of its subterranean homes. During heavy rain-falls the water rushes with great violence through the eaves and doubtless often carries the erayfish out to the rivers. IIere its light color, soft shell and defenseless eondition would prove such a heavy handicap that in the struggle for existence its life would be of very short duration. It is usually found in shallow pools with muddy bottom rather than in rapidly flowing water. It moves 
slowly with its antenne spread out before it, and gently waving to and fro, feeling, as it were, every inch of its way. It is wholly non-sensitive to light, and seemingly so to sound, but when disturbed by any movement in the water it is extremely active; much more so than ordinary terrestrial forms, leaping upward and backward with quick, powerful, downward blows of its abdomen.

Several branches leave the main passage of Shiloh Cave, but all but one are short in length. The one exception turns to the right about 1,500 feet from the entrance and extends in a southwesterly direction. At

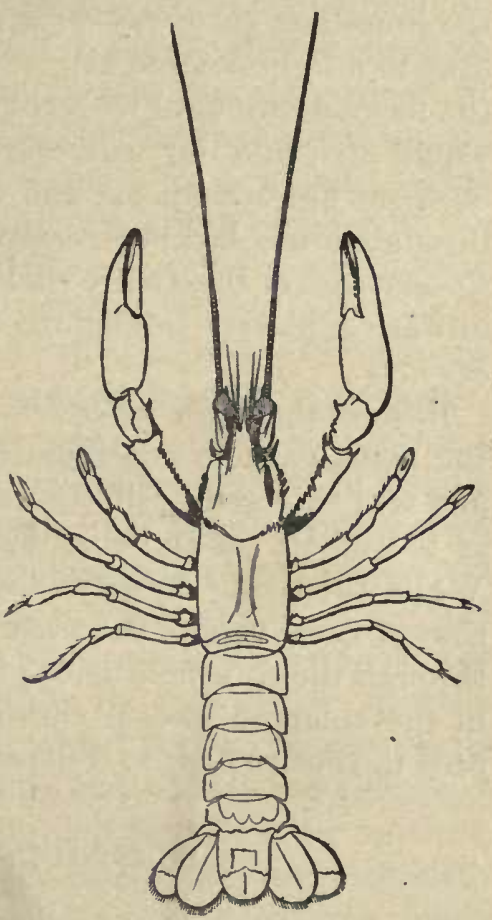

Fig. 28-Blind Crayfish.

(Three-fourtlis natural size.)

first it is a high, narrow fissure with the jutting walls bearing many stalactites. A stream of water covers the entire floor and from far in the distance comes a murmuring sound caused by a succession of water-falls, four in number and in size small, which occur at short intervals along the passage. Wading through pools, clinging to corners of jutting ledges, 
climbing over slippery, perpendicular banks we made our way until finally the passage began to rise, and the limestone gave way to a dark shale and this in time to a light colored elay. We were 900 feet from the fork and thought we were nearing the surface and would soon find our way above ground, when all at once our lights went out and we staggered backward through utter darkness, eseaping, as if by a miracle, the clutches of the deadly choke-damp which lurks for unwary explorers amidst the deepest recesses of this cave.

Beyond the point where the right branch leaves it, the main passage continues in a southerly direction and was explored until the back water from the dam at the mouth of the eave became too deep to wade. While preparing to leave the eave a heavy thunder shower came up and the water soon poured in torrents through the sink-hole and adding its volume to that of the enlarged stream within the eave, quickly covered the entire floor to a depth of nearly two feet.

\section{DONNEHUE'S CAVE.}

The mouth of this cave is located near the foot of one of the bluffs of White River, 500 yards distant from that stream and two and one-half miles southwest of Bedford, Lawrence County. From the mouth of the cave a small stream finds its way, the source of which is in a sink-hole three-fourths of a mile clistant in a north-easterly direction. The stream is greatly enlarged after a heavy rain and by its erosive action the cave is constantly but slowly increasing in size. 
Entering the cave, one finds himself in a commodious room, 10 feet high and 48 feet in width, the floor of rock, covered in places to a depth of two or three feet with alluvial drift. Fifty feet back this narrows to 12 feet in width and a short side passage puts off to the left, in which a number of the cave salamanders, Spelerpes maculicaudus (Cope), were found. This handsome batrachian was taken in a number of the caves visited and doubtless occurs in all Indiana caverus which contain streams of water or damp rooms near the entrance. In life it is a

The Cave Salamander.

bright orange-yellow with very numerous black spots, which, on the back and sides, vary much in size and shape. The body is quite slender and reaches a total length of $6 \frac{1}{4}$ inches.

It is usually found clinging to the walls within 150 feet of the entrance of the caves, especially in crevices and crannies just above flowing streams or pools, but never in the water. While its eyes appear as large and normal as those of allied terrestrial species, its sense of sight seems to be limited. It remains quiet when discovered and shows little fear until touched, when it scrambles deeper into a crevice or beneath some fallen rock on the floor. Even when a candle is put within a few inches of its head it does not move until it feels the heat. Its food probably consists of such insects and small crustaceans as are found along the margins of the streams.

Back 180 feet from the mouth, the main passage of the cave is $6 \frac{1}{2}$ feet high by 6 feet broad, the stream on the floor being about three feet in width and three inches deep. Farther on this stream deepens and 
several pools were found in which the water was two or more feet in depth. At a distance of 325 feet the passage forks, and from the right-hand branch came so strong a current of air that it was impossible to use
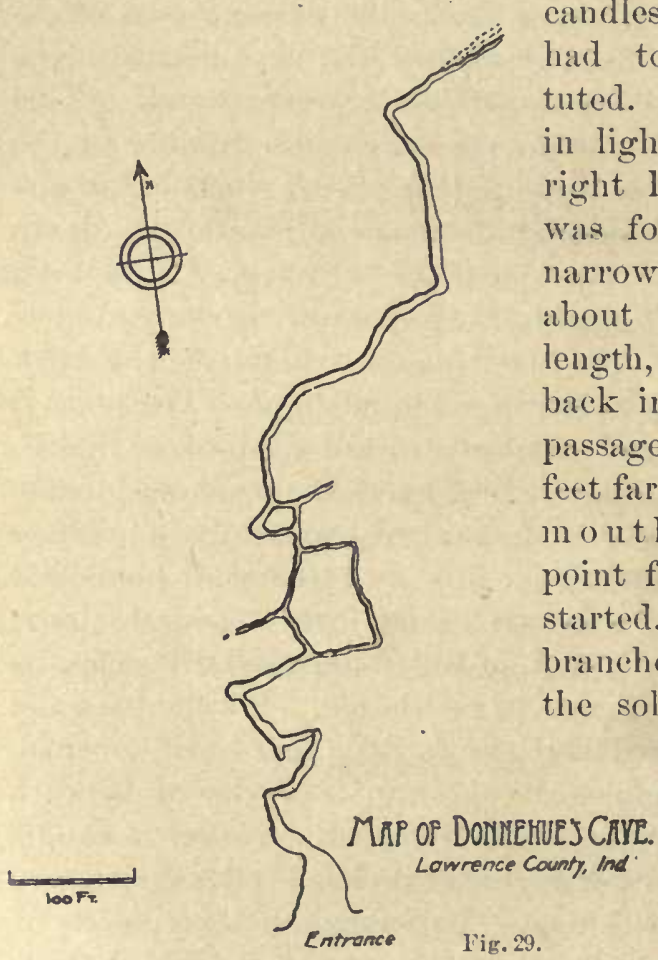

candles and lanterns had to be substituted. The ehange in lights made, the right hand passage was found to be a narrow, winding one, about 150 feet in length, and to lead back into the main passage about 100 feet farther from the mouth than the point from which it started. All these branches are through

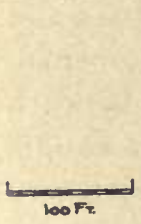

Fig. 29. are only water channels three or four feet high and about as wide.

Beyond 425 feet, several side branches were found to contain water too deep to wade, or to soon beeome too low for further progress; in fact, the roek is more honeycombed with small passages than in any cave risited. The main lassage, however, at about 500 
IX.

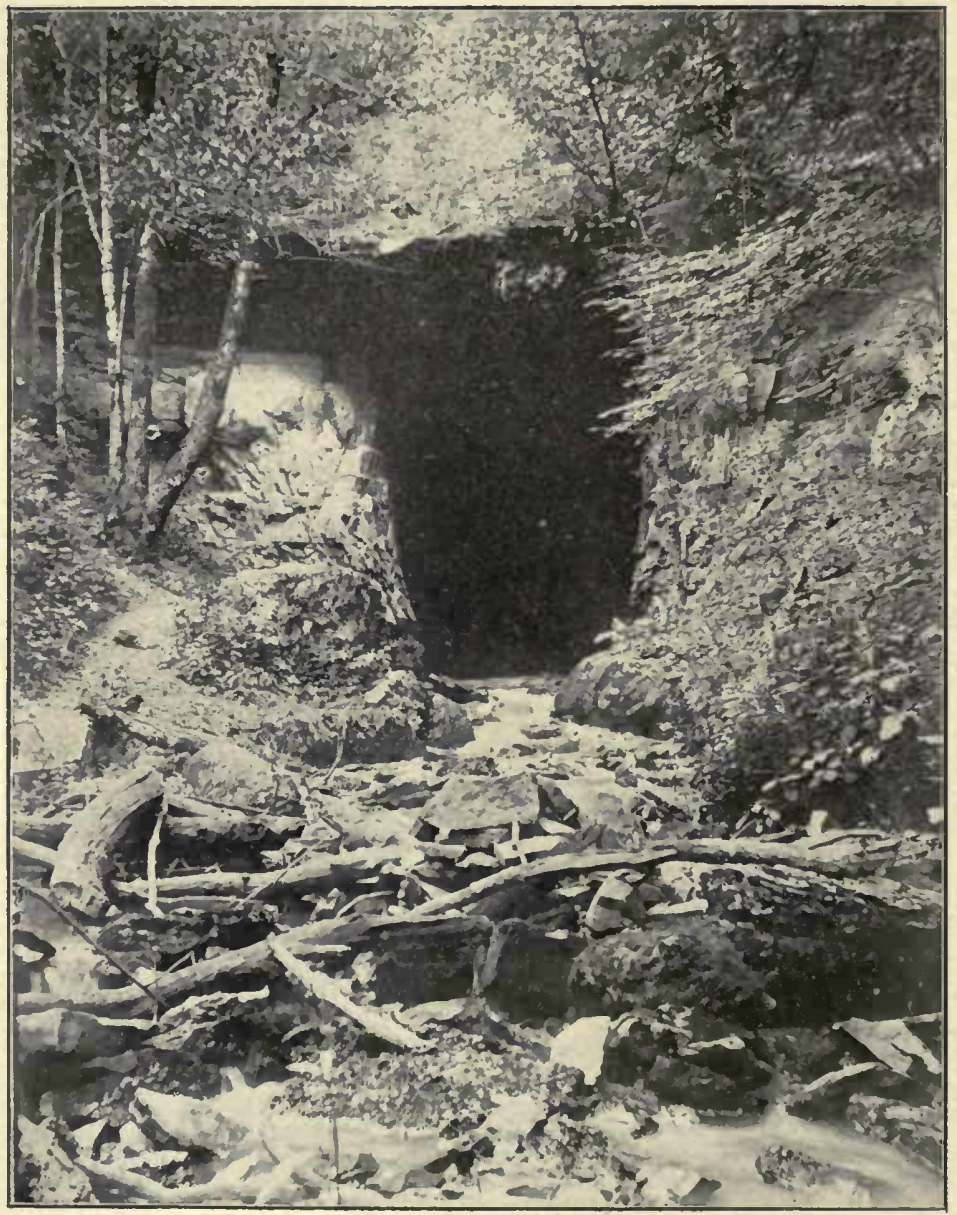

Mouth of Shawner Cave. 
feet from the mouth, enlarges to a height of 40 feet and a width of eight to ten. This portion was, for the most part, dry, the stream having disappeared in one of the low chamnels already mentioned. In some places two floors are found; in others the greater part of the upper floor has fallen in, leaving a portion in the form of a natural bridge spanning the passage from side to side. At a point 950 feet from the mouth the upper passage ends against a perpendicular wall of rock, from near the top of which is a passage onward, but too high from where we stood to admit of entrance. The lower passage was followed to about the same point, where it became two feet high and three feet wide and almost filled with water, thus barring further progress. But few stalactites were found in the cave, and they were mostly of small size and unattractive appearanee.

\section{SHAWNEE CAVE.}

Among Indiana caverns the mouth of Shawnee Cave ranks next to that of Porter's in picturesque beauty. Indeed, by some it is classed as more attractive. The mouth of the eave is found at the head of a deep gorge worn through the limestone by a good sized stream which flows from the eave and down the gorge to the broader valley beyond. Many centuries ago the cave extended the full length of the gorge, and the waters of the stream flowed directly from its mouth into the valley. The roof of the under-ground channel finally became so thin that it collapsed, the grorge was then started and, as the centuries went by, 
grew in length, the cave ever becoming shorter by the continued falling of the roof. Both gorge and cave are located about three miles south-east of Mitchell, Lawrence county, in a region noted for the beanty of its scenery.

Three passages open directly into the mouth of the cave. The right hand passage has the level of its floor about five feet above that of the entrance, while the opening on the left is 12 feet above the bed of the stream and very difficult to enter without a ladder. The middle passage extends straight back from the common vestibule or main entry. The latter is twenty-five feet long, twenty-one feet high and eighteen feet wide, but at its farther end is reduced to the narrow middle passage between great masses of limestone. The water in this passage is waist deep and explorations must be made by wading or in a light canoe. One hundred feet within is a magnificent cascade, where the stream rushes and leaps down a narrow passage with such violence that the noise is. plainly heard at the entrance.

The right hand passage, for the first 100 feet, is about ten feet high by fifteen wide, with a clay bottom and a roof on a level with that of the vestibule. It then expands into a large room, 230 feet long aud forty feet wide, which lies east and west at right angles to the entering passage. This narrows at the west end to twenty feet and at one point the outer air flows in through a small opening in the roof. From near the smaller end of the room a narrow passage starts off to the southward and can be traveled for 200 feet, when it becomes too narrow for further 
advance. Along this passage a small stream flows, disappearing through a hole in the floor near the entrance to the larger room. Other than this, both right and left passages leaving the main entry are dry.

The passage at the left of the main entrance to the cave is about 150 feet long by twenty broad, and contains no points of especial interest. No stalactites worthy of notice are found in this cave. The name "Shawnee" has been given it from its being near the center of the former hunting grounds of the Shawnee Indians. It was doubtless used by them as a place of shelter since many relies have, from time to time, been found about its mouth. In the early settlement of this region the nitrous earth on the floor of the two dry passages was used in the making of saltpetre; and the stream flowing from the main cave was afterwards dammed and utilized for a number of years in driving a woolen, grist and saw mill.

This stream is one of the largest issuing from an Indiana eave. It flows for a long distance underground and in several places south of Shawnee Cave the roof of its subterranean passage has caved in, causing deep ravines at the bottom of which the stream meanders, until it reaches a point where the roof of stone remains intact, and the entrance of a new cave begins, into which the waters disappear, as

\section{"Alph, the sacred river, ran}

Through caverns measureless to man,

Down to a sunless sea."

In this stream the blind fish, Amblyopsis spelocus DeKay, occurs in numbers, though never more than two 
and seldom but one are seen at a time. When full grown this fish reaches a length of four and a half The Blind Fish. inches. Thie body is colorless, the The Blind Fish. seales very small and the young are born alive. No external traces of eyes are to be found in adult specimens, but the loss of sight is in part compensated by numerous touch papillæe, arranged in ridges on the sides and front of the head.

These eyeless fishes move very slowly through the water, usually near the surface and elose to the edges of the deeper pools which they inhabit. They are wholly non-sensitive to light, but extremely sensitive

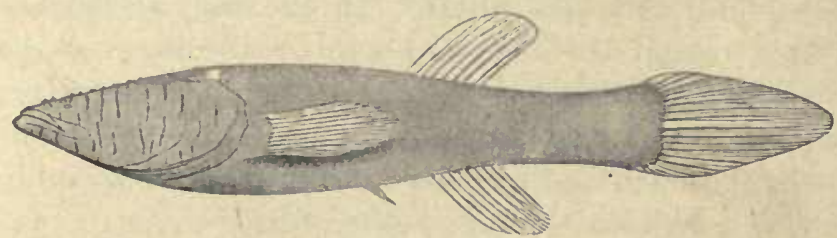

Fig. 30-Blind Fish.

(Three-fourthe natural size.)

to tonch or any jar or motion of the water. They were readily caught by putting a dip-net very gently into the water a foot or two from them and then making a quick forward and upward scoop. If in still, deep water, they seem to glide, or rather float, on and on, propelled by a seareely perceptible motion of the caudal fin. One must think of them as ever surrounded by an intense darkness, the prey of every fish-loving animal, as mink or coon, that can swin and see in the darkness, the white skin of the fish readily revealing its presence if the least gleam of light reflects from its sides. 
Concerning the sense of hearing as developed in this species Prof. E. D. Cope has written as follows: "If these Amblyopses be not alarmed they come to the surface to feed and swim in full sight, like white, aquatic ghosts. They are then easily taken by the hand or net, if perfect silence is preserved, for they are unconscious of the presence of an enemy except through the medinn of hearing. This sense is, however, evidently very acute, for at any noise they turn suddenly downward and hide beneath stowes, etc., on the bottom."

My observations do not bear out the above statement. I talked and even hallooed close to the fish without cansing them to take alarm, but the least movement of the water friglitened them, and they darted rapidly away, usually at right angles to the course they were pursuing. The sense of tonch, rather than that of hearing, is, in my opinion, the one which has been intensified by long residence in the dark and silent recesses of the caves. In a number of instances, as the dip-net was raised quickly upward, the fish leaped several inches above the surface of the water in a vain endeavor to eseape.

In one place where a stream flows out of a cave and through a deep ravine for about 200 yards, and then enters another cave, the blind fish were captured in both caverns within 100 feet of the openings, and there is little doubt but that they make their way through the open stream from one to the other. "The eaves and under-ground streams of southern Indiana doubtless form a more or less complete system of subterranean drainage, and throngh this the blind fish 
finds its way wherever the water is deep enough to allow it passage.

In captivity this fish eats very little. Dr. Sloan, of New Albany, who kept specimens in an aquarium for 20 months, says: "They have taken no food, except what has grown "p in the water and on the sand in their tank. . . . Some of then would strike eagerly at any small body thrown in the water near them, rarely missed it, and in a very short time ejected it from their mouths with considerable force. I often tried to feed them with bits of meat and fresh worms, but they retained nothing. On one occasion I missed a small one and found his tail projecting from the mouth of a larger one; I captured and released him."

In nature they doubtless feed upon one another and upon the blind crayfish and smaller crustaceans which inhabit with them the streans of caves. A number of those captured were "nosing," as they slowly swam, the rocks along the sides of the pools, and it is possible that they gather some organic matter from the slime on these rocks.

\section{CLIFTY CAVES.}

The mouths of the two Clifty caves are about 200 yards apart, and are loeated at the head of a deep and narrow valley about three miles north of Camplellsburg, Washington County. Clifty Creek has its source in the streams which emerge from the caves, and flows in a north-westerly direction about four miles to White River, into which it empties. Its valley, especially the upper half, is noted for the wild 
and rugged seenery and the vicinity of the eaves is a noted resort for pleasure seekers.

The caves are designated, respectively, by the terms "wet" and "dry," the former being the smaller of the two. Across the mouth of the Wet Cave a dam has been built, and the water emerges from it with sufticient force to turn the machinery of a distillery and grist mill ; both abandoned, however, since their owner died, a few years ago. The month of the cave is a perfect archway in the solid limestone, fourteen feet wideand eleven feet from roof to botton. The water behind the dam was two and a half feet in depth, and deepened rapidly as one went back, and the eave was explorable only by means of a boat, which was not at my command.

Dr. John Sloan of New Albany, Indiana, at one time went up the stream in the Wet Cave for abont $200 \mathrm{yards}$ on a raft of timber, at which point rapids were encountered, over which it was impossible to lift the raft, and the water above being too deep to wade, he was obliged to return.

The Dry Cave was explored for a distance of 2,650 feet, beyond which it was impossible to proceed. The entrance is larger than that of the Wet Cave, being eighteen feet high and twenty feet wide. Back 100 feet it narrows to thirteen feet in width, and, fifty feet farther, to about eight feet, the water at this point covering the entire floor to a depth of six inches. For the first 500 feet the main passage is very erooked, but beyond that point it is comparatively straight and extends in a general south-westerly direction. Like Porter's Cave, it is a mere water-worn passage, with 
no large rooms, few stalactites, and, in general, may be said to be monotonous. The stream on the floor winds from side to side of the cave, thus making the frequent crossing of it necessary.

In a shallow pool of water, 1,200 feet from the entrance of the cave, a fine specimen of the blind crayfish was secured, and about fifty feet distant, in a deeper pool of the main stream, numbers of a common species of an above-ground crayfish, Cambarus bartonii (Fab.), were found. Whether these seeing forms pass their entire lives in the total darkness of the cave or whether they make an occasional visit to the outside is a question as yet unsolved. The same species was found in several other caves and seems to have a liking for clear, cold water and underground resorts. If these habits be continued a "new species" of blind erayfish will, in time, result; for there is little doubt but that the ordinary eyeless form has evolved from a seeing one which, ages ago, found its way, voluntarily or otherwise, into the under-ground streams. Finding there the struggle for existence less deadly than among its numerous kin of the surface waters it slowly adapted itself to its surroundings. Having no need for its eyes they, in time, became aborted, for nature always rids her objects of every organ which, from a change of environment or habit, becomes to them useless.

Several specimens of above-ground beetles were taken from the margin of the stream in this cave, but they had probably been washed in by the heavy rains of the week before. The most interesting insect secured was a cave harvestman, Scotolemon facescens 
(Cope), which is elosely allied to the common "daddy long-legs." It is, however, much smaller, and pale yellow or reddish in color. It frequents the surface of damp rocks and probably feeds upon the little cave "spring-tail" which was everywhere abundant.

Several short side branches diverge from the main one, and at a distance of 1,300 feet from the mouth a large branch turns oft to the right, which was explored for abont 400 feet, but not to the end. The main passage continues to the

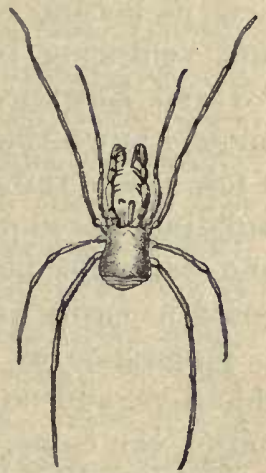

Fig. 31-Cave Ilarrestman. (Much enlarged.) left, and at 1,800 feet a large rock $30 \times 15$ feet was found which had fallen from the roof and partially blocked the way. Two thousand feet from the entrance the passage widens into a room 100 feet aeross and four feet in height, which contains much fallen rock, but nothing else of especial interest. Beyond this the cave narrows again and varies from twenty to thirty feet in width as far as explored.

\section{MARENGO CAVE.}

This cave, which next to Wyandotte is the most noted in Indiana, is located a short distance north-east of Marengo, Crawford County. It has been known only since 1883, and the owners of the land on which the entrance is located were wise enough to prevent the ruthless destruction of the stalagmites and stalaetites which form the main beanty of the cavern. Some 
children playing about a sink-hole in September of that year, noted an opening which had been formed near its bottom by a recent falling of earth and rock, and venturing in, found the room now known as "Grand Entrance Hall." Afraid to go farther, they made known their discovery to other persons, and in a few weeks the entire cave had been explored. A building was soon afterward erected above the mouth, and stairways built, so that entrance into the cavern could be easily and safely made.

Thonsands of visitors have since passed through this cave, and no one who is at all in sympathy with nature can come forth from its corridors and passages without feeling fully repaid for his peep into one of her under-ground ehemical workshops. There, the only materials necessary are water and limestone. Given these, and time unlimited, the varied character and wonderful beauty of the products possible can only be realized by those who have spent a few hours in a cavern like Marengo.

Descending the stairways, after having been provided with a lantern and guide, the visitor finds himself fifty feet below the surface in the large vestibule known as the Grand Entrance Hall. This is a room fifty feet wide and twenty to thirty feet in height, the floor of dry earth, and with two passages diverging, one ascending to the right and leading through the Short Route and Crystal Palace, the other descending to the left and leading through the Long Route.

Taking first the latter, we found the main passage to be 12 feet high and about 20 feet wide. Seattered at intervals along its walls and roof were many stalac- 
tites, some in groups, others singly, and all possessed of fanciful names given them by former visitors or by the proprietors and guides of the cave. One hundred feet from the foot of the entrance is a slab of limestone, fallen from the roof, whose dimensions are $18 \times 8 \times 4$ feet. This is known as "Fallen Rock," and beyond it a short distance is, on the right, a passageway known as the "Cut Off," which leads to the Crystal Palace. Continuing, the main passage widens to 30 or more feet, and for a distance of 80 feet is known as "Statue Hall." In this are some noteworthy formations, the prettiest of which is "Mt. Vesuvius," a lange, rounded stalagmite. Above it is a group of slender stalactites, down, which a stream of water trickles and gives a muddy character to the floor for a distance of several hundred feet.

Crawling over the damp rocks were several specimens of a small, light yellow spider, Nesticus carteri Em., which were quickly consigned to a vial of alcohol. It belongs to the group of "wandering spiders" whose members spin no webs, and its food is doubtless the little cave "spring-tail" which occurred by thousands in the same damp area. Here, also, were taken the first specimens of a blind myriapod, afterwards found in great numbers in $W_{\text {yandotte Cave. }}$

Congress Hall succeeds Statue Hall and contains along the edge of the ceiling some handsome formations, known as the "Giant's Mitten," "Manmoth Pen," etc. From this hall the bed of an old stream leads to the right beneath the massive limestone walls. "Mammoth Hall," with a width of sixty-five feet and a length of about 300 , comes next in order, and con- 
tains the "Elephant's Head," "Folded Lambrequin," "Bridal Curtains" and other fantastic formations of

\author{
1. Grand Entrance \\ Ilall. \\ 2. Cut Off. \\ 3. Congress Hall. \\ 4. Mammoth Iall. \\ 5. Elks' Hall. \\ 6. Music Ilall. \\ 7. Cave IIill Cemetery. \\ 8. Creeping A re. \\ 9. Junetion Room. \\ 10. Fairs Palace. \\ 11. Prison Cell. \\ 12. Prison Bars. \\ 13. Washington A re. \\ 14. Lovers' Retreat.
}

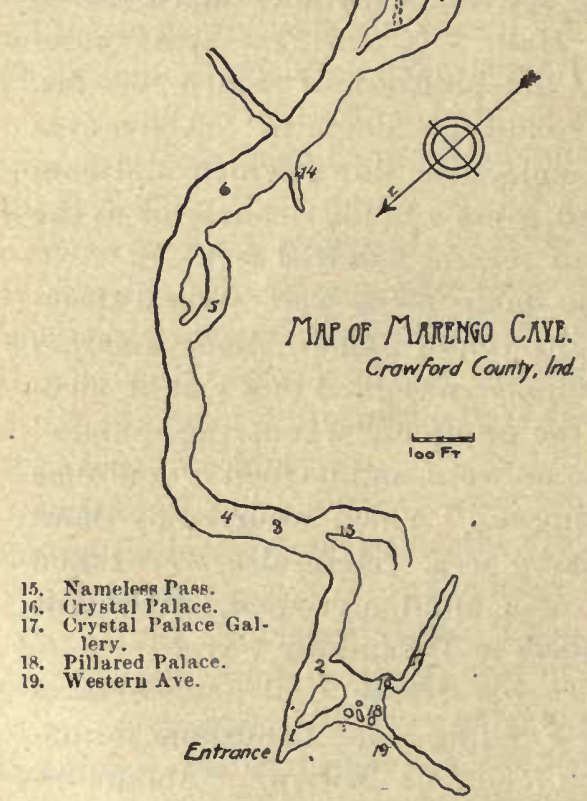

Fig. 32. carbonate of lime, wrought in darkness in the ages past.

Beyond Mammoth Hall the passage divides and passes around a mass of uneroded limestone. The branch on the right rises ten or fifteen feet above the level of the main floor and enlarges into " Elks" Hall,", a room 190 feet long and twenty feet high. Beyond this hall the two branches soon unite and at a distance of 1,000 feet from the entrance enlarge into "Music Hall," a large room containing a raised platform of rock, known as the "Band Stand." A short distance farther on, a branch goes off to the left which has been explored only by 


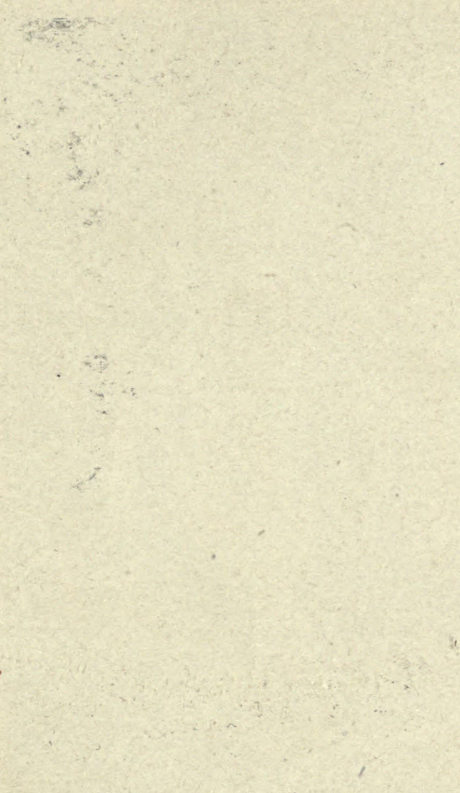


$\mathrm{X}$.

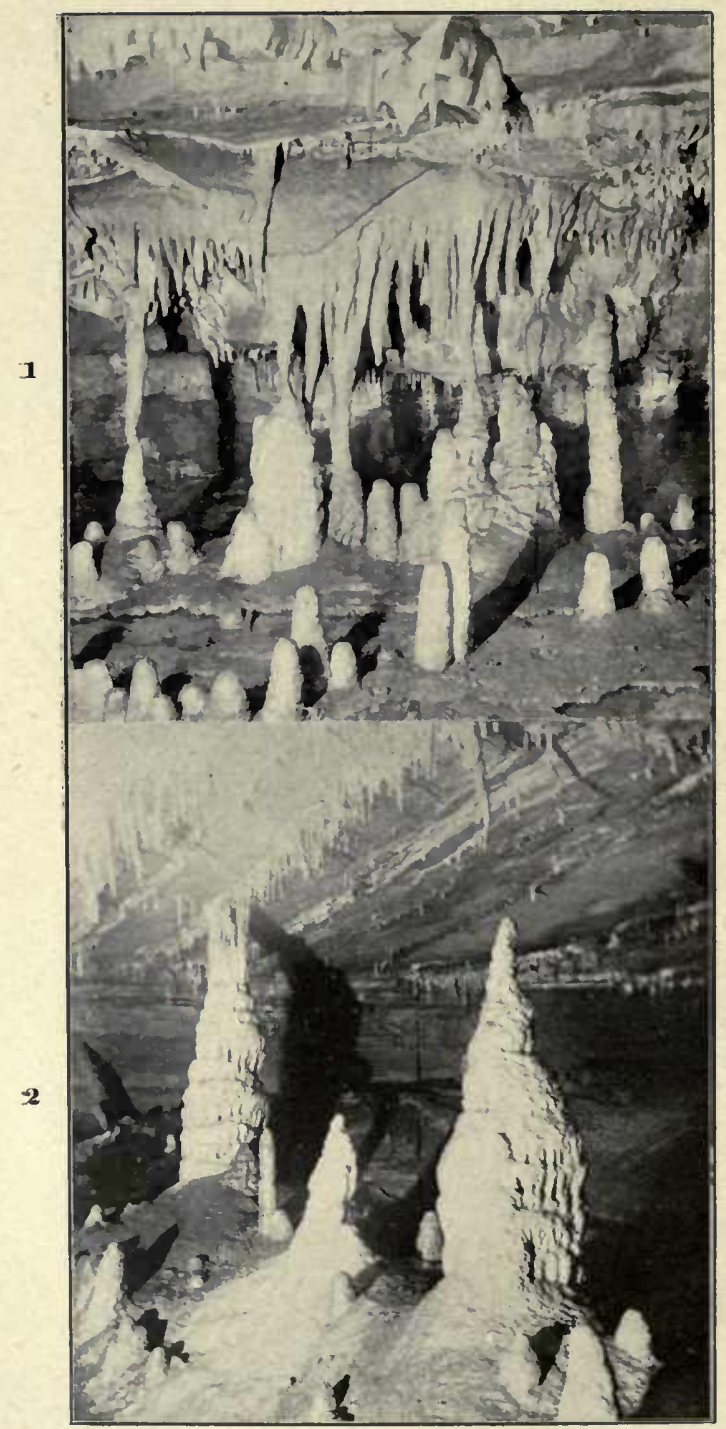

1. Corner of Cave Hill Cemetery, Marengo Cave.

2. Tower of Baber, Marengo Cave. 
guides, the ceiling being low and the scenery possessing no especial interest.

Fourteen hundred feet from the entrance the main passage again forks, the right branch containing "Cave Hill Cemetery." Herein are found some beautiful stalagmites and pillars, one of which, called "Washington's Monument," is among the most striking: objects of the eave. Its height is four feet, eleven inches, and a foot above the base it is two feet in eircumference. Composed of the clearest of erystalline limestone, it stands with its white surface gleaming in the dim lantern light, inspiring the visitor with a feeling of wonder as to how an object of such beanty and purity could have been formed in these depths of Cimmerian darkness. Another monument of greater size, but less imposing on account of its yellowishbrown color, is the "Tower of Babel"-ten feet high and six feet, eight inches in circunference. It stands among numerous smaller stalagmites, a short distance beyond Washington's. Monument.

Beyond the tower of Babel the roof of the right branch lowers, and it is necessary to crawl through a narrow opening and then ereep or stoop for quite a distance through "Creeping Aventue," passing meanwhile among many pillars, stalagmites and stalactites, varied in form and beautiful to look upon. Emerging from this avenue we stood erect in the "Junction Room" 2,000 feet from the eave entrance, and at the point where the branch which turned to the left at the entrance to the Cave IIill Cemetery meets the right branch through which we have traveled. Beyond this point the cave narrows and the roof eomes down 
within a foot of the floor. By creeping, crawling and twisting from side to side we managed to get up a slippery hill and through a small opening into the "Fairy Palace," a place visited by few on account of the diffieulty of the way. Here we found the farthest explored part of the eave, and in the small room, perhaps ten feet wide and five feet high, were thousands of formations, which reflected the light in a most brilliant manner.

Retracing the way to the Junetion Room, we turned to the right into the "Prison Cell," a large room which contains some of the principal features of the cave. Here is the "Leaning Tower of Pisa," a stalagmite six feet high, with the top inelined several inches beyond the base; "Solomon's Temple," a group of slender pillars six and a half feet in height and arranged in a circle; "Administration Building," a pillar made up of a series of eireular layers of crystalline limestone, piled one on top of another so as to eause the whole to resemble a Japanese pagoda; "Bunker Hill Monument," formed on a fallen slab, story on story as the preceding, besides many others as handsome, yet too numerous to mention. We passed from the Prison Cell, between the "Prison Bars"- a series of slender columns six feet long and six to eight inches in circumferenee-into "Washington Avenue," the left branch of the main passage at the fork near Cave Hill Cemetery. This avenue is 450 feet in length, from twenty-five to forty in width, and for about one-third of its length the ceiling is so low as to require a stooping position in passing through. On the way are many small stalagmites grouped in a straggling 
fashion, "Grant's Army" and "Coxey's Army" being the names given to two of the largest assemblages. The floor of Washington Avenue is dry and for the most part composed of earth, with here and there a slab of fallen rock. Near the fork it elescends for about fifteen feet and we enter once more the main passage, already described, and make our way along it to the "Cut Off" leading to Crystal Palace, passing on our left the "Lover's Retreat," a winding cleft which extends about seventy-five feet back into the solid limestone.

The Crystal Palace is the crowning glory of Marengo Cave. It is a small alcove or side room, ninety feet long, fifteen feet wide and about twenty-five feet in height. At the south end is a perpendicular wall along which is a drapery or vast sheet of stalactites, and from a projecting shelf are many slender stalagmites, the whole so grouped as to resemble a giant pipe-organ. The side walls are studded with hundreds of small and large formations, while from the roof hang, pendent, myriads of slender stalactites of the clearest crystal, which reflect with sparkling brilliancy the rays of the calcium or magnesium flash lights. By ascending a stairway fifteen feet, one fiuds himself on a baleony in the very midst of these formations and can pass back into "Crystal Palace Gallery," a low passage, about 150 feet in length, the floor of which resembles a relief map, being thrown up in many places in narrow corrugations and ridges, with here and there a pool of limpid water occupying the irregular and shallow depressions.

Descending the stairway and passing to the left, 
we enter the "Western Arenue or Short Ronte," the prineipal feature of which is the "Pillared Palace," where giant pillars, stalactites and stalagmites are so numerous that it is with difficulty the visitor winds his way between and around them. This portion of the eave extends but about 150 feet in a westerly direction, and into it has been dug an artificial opening from the surface, forty feet above. Retracing our steps for the last time, we turn to the left at the mouth of the Pillared Palace and pass through another bower of beauty, the "Queen's Palace," a small room whose walls are composed wholly of pillars and stalagmites. Beyond this we pass the "Diamond Dome," the largest stalagmite of the cave, thirty-one feet in diameter and reaching from ceiling to floor, and emerge into Grand Entrance Hall, which was our starting point.

In the erevices of the walls of this hall the cave salamander has its abiding places and among the debris which has fallen from the roof a number of whitefooted mice, Calomys americanus (Kerr), have taken

A Cave Inhabiting Mouse. up their home. They have been noted ever since the cave was discovered, but seem to keep close to the entrance, through which, however, no light passes. In the winter season they are very destructive to sweet potatoes and pumpkins stored in the eave, and at other seasons evidently subsist upon the tallow drippings and other refuse matter left by the visitors. They differ much in. appearance from above-ground examples of the same species, having larger external ears, longer whiskers and more protruaing eyes. 
Such changes have been brought about by their life in the darkness, and are but the beginning of a series of adaptations to their changed surroundings which will eventually result in a "new species of blind mice," provided such a life be continued for any length of time.

Careful measurements showed the total length of Marengo Cave, including the side branches, to be 3,850 feet. Within this distance of less than threefourths of a mile are probably crowded more beantiful formations of crystalline limestone than in any other known cave of similar size in the United States.

Lacking the length, the lofty vaulted rooms and the grand scenery of Wyandotte, Marengo far excels that cave in the abundance and beauty of its stalactites, stalagmites and other like formations. To those who wish but a glimpse of under-ground life, we most heartily commend it, believing that a visit of a few hours will repay all who take an interest in the mysterious and beautiful in sature.

\section{WYANDOTTE CAVE.}

Next to Mammoth Cave, Kentucky, Wyandotte is the largest cavern in the United States. Its enormous under-ground halls and vaulted domes, its gigantic fluted columns and vast piles of fallen rock, are unexcelled in any other American cavern. Its situation among the rugged hills which form the breaks of the Ohio River, in a country as yet primitive in character, where game is plentiful, and fisling in the clear waters 
of Blue River exceptionally good, make it a most inviting spot for a summer's outing.

Around the hotel, situated close to the cave on a commanding eminence in a natural wooded grove, grow numerous forms of plant life which are strangers to central and northern Indiana, while in the cave dwell many sightless animals whose habits of life are yet unknown; so that the botanist and zoölogist may add to the study of the cavern itself the pursuit of their favorite subjects.

The first published account of Wyandotte Cave was probably in 1833, in "Flint's Geography of the Mississippi Valley," as follows: "Like Alabama and Tennessee, Indiana abounds with subterranean wonders in the form of caves. Many have been explored and some of them have been described. One of them is extensively known in the western country by the name of 'the Epsom Salts Cave.'

"It is not very far from Jeffersonville. When first discovered the salts were represented as being some inches deep on the floor. The interior of this care possesses the usual domes and chambers of extensive caverns, through which the visitant gropes a distance of a mile and a quarter to the 'pillar,' which is a splendid column, fifteen feet in diameter and twenty-five fect high, regularly reeded from top to bottom. Near it are smaller pillars of the same appearance.

"The salt in question is sometimes found in lumps varying from one to ten pounds. The floors and walls are covered with it in the form of a frost, which, when removed, is speedily reproduced. The earth yields from four to twenty pounds to the bushel, and 
the product is said to be of the best quality. Nitre is also found in the eave in great abundance, and sulphate of lime or plaster of paris."

The month. of Wyandotte Cave is located in Jennings Towuship, Crawford County. The nearest railway, the "Air Line," passes through Milltown, which is nine miles distant from the cave, over an exceedingly rough road. From Corydon, the eounty seat of Harrison County, the distance is about twelve miles, and the road a fair one for southern Indiana. This route is a most pleasant drive in the summer or autumn, and leads one down the romantic valley of Blue River. For several miles the road follows along the limestone bluff on the right side of that stream, in many places having been excavated in the side of the bluff forty or more feet from the water below. From Leavenworth on the Ohio River, the nearest point for steamers, the distance is five miles.

According to measurements made by Prof. Collett, the Cave Hotel is 220 feet above Blue River, across whose narrow valley "Greenbrier Mountain, with sharp, conical peak and steep faces, belted with massive rings of rock and variegated with evergreen cedars, aftords a scene of quiet, stately beauty." From the hotel a pathway leads down a gradual slope to the mouth of the eave 100 yards away.

That portion of Wyandotte known previous to 1850 is at present called the "Old Cave," and will be first described, since one must traverse a portion of it in order to reach the entry of the "New Cave," discovered in the year mentioned. 
I. Saltpetre IIoppers.

I. A rched Entrance.

2. Faneuil IIall.

3. Columbian A reh.

4. Fulling Rock

5. Wyandlotte ('hief.

f. Entrance to New Cave and Fat Man's Misery.

7. Banditt! Iall.

8. Jacob's Ladder.

9. Pigniy Dome.

11. Debris Dome.

11. Continued A rch.

12. The Canopy.

13. Lucifer's Gorge.

14. Natural Bridge.

15. The Stoop.

16. Temple of llonor

17. Secret Entrance to Rotlirock's Straits.

15. Odd Fellows' Hall.

19. J'hantom Slip. "Millie,"

21). J'haraoh's Stairway.

21. Conrad's IIall.

22. The Cliffs.

23. The Pit.

24. Falls of Minnehaha.

25. Dead Fall.

26. Cyclope' Chasm.

27. Lead Sea.

28. Screw Hole.

29. Polished BowIdersIndian.

30. Senate Chamber.

31. Chuir of State.

32. Pluto Ravine.

33. StaIIasso Monnment.

34. Stillo Mountain.

35. Pillar of the Constitution.

36. I]eman's Bower.

37. Hino Cliffs.

3*. Lonigan's Pars.

39. Diamond Laby rlnth.

40. Enmoncey A rcade.

41. Rode Rock No. 1.

42. Q neen Mab's Retreat.

13. Snow Banks.

44. Zoe Grotto.

45. Ice II ouse.

46. Frosted Rock.

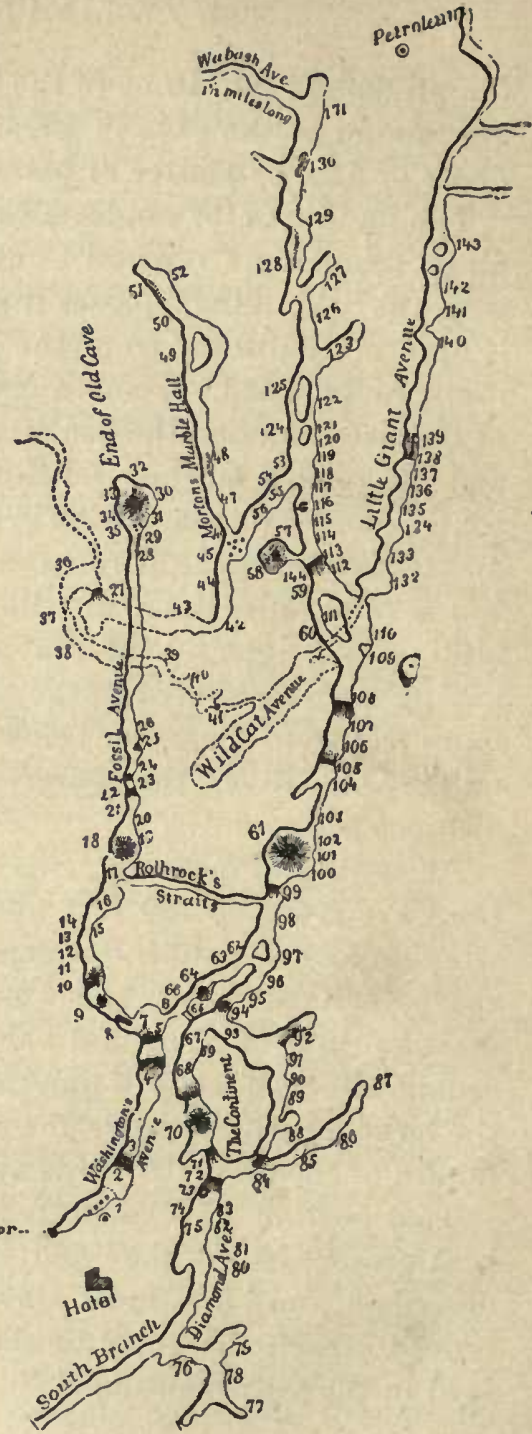

Fig. 33-Map of Wyandotte Cave. 
47. Snowy Cliff.

48. Indian Footprints.

49. Beauty's Bower.

5). Queen Mab's Marble Garden.

51. Fairy Palace.

52. Wyandotte Potutoes-Pebles.

53. The Arn Chair.

54. Lovers' Retreat.

55. Ewing Hall.

56. Frost King's Palace.

57. Bowlder Flints.

58. Milroy's Temple.

59. Penelope Grotto.

fil. Ulysses' Straits.

61. Rothrock's Cathedral.

62. Coons' Couneil Claaber.

63. The Rotunda.

64. Rugged Nountain.

6.5. Cut Off.

66. Counterfeiters' Trench.

67. Starry Hall.

6s. Wyandotto Grand Council Chamber.

69. The Card Table.

70. Hall of Representatives.

il. Hill of Science.

72. The Alligator.

73. The Mound.

7.1. The Throne.

75. General Scott's Reception lioom.

76. Ante-room.

77. Hovey Point.

78. The Pit and Sieve.

79. The Amplitheuter.

80. Rocky Hill.

81. Muddy Fork.

82. Lost Rivulet.

83. Frozen Cascades or Curtains.

84. The Hippopotamus.

8i. Fairy Grotto.

86. Neptune's Retreat.

87. Hermit Cell.

88. The Sepulchre.

89. Purgatory.

90. Calliope Bower.

91. Palace of tlıe Geni.

92. Pillared Palace.

93. Creeping Avenue.

9. Junction Ronn.

95. Urawing lioom. 9i. Dining Room.

97. Deltn Island.

95. Sundy Plain, 3n) feet long.

99. Hill of Dillienlty.

10n. Monument Mountain.

101. Sulphur Spring.

112. The Anger Ilole.

I13. Lilliputlan Hall.

114. Spade's Grotto.

105. Slippery Hill.

1kr. Hall of Ruins.

117. White Cloud Room.

1118. Sentinel Office.

1(4). Bishop's Rostrum or Pulpit.

110. Journal Office.

111. Calypso's, or Jkland No. 2.

112. Cornlean Vault.

113. Rugged Pass.

114. Chapel.

115. Vestry.

116. Josephine's Arcado.

117. The Parsonage.

118. The Junction.

119. Tho Lono Chamber or Ball Room.

120. Dry Branch.

121. Island of Confusion, or No. 3.

122. Grand View Island, or No. 4.

123. Sandy Brunch and Air Torrent.

124. Newhall's Forum.

125. Grosvenor's Avenue.

126. Gothic Chapel.

127. The Gallery.

12s. Indiun Footprints.

124. The Dew.

130. Slip in the Stocks.

131. Crawfish Spring.

132. Maggie's Grotto.

133. Joseph's I'it.

134. Lama's Bower.

135. Marble Rivulet.

136. Marble llall.

137. Miller's Reach.

138. Andrew's Retreat.

139. Rorle Rock No.2.

140. The Devil's Elbow.

141. The Pit.

142. Langsdale's llasin.

143. Wasl. Iioth roek's Island.

14. Buurbonoi. 
THE OLD CAVE.

The entranee of Wyandotte is twenty feet wide and six feet high; the roof arehed, the floor of earth, with here and there a fallen slab of rock. For perhaps 100 feet we descended gradually and entered a spacious corridor known as "Faneuil Hall," forty feet wide, eighteen feet high, and probably 180 feet in length. Across the farther end of this hall a stone wall has been built and a doorway constructed, and through this one passes into "Twilight Hall," where the last rays of daylight disappear and the King of Darkness begins his reign. Here we stopped a few moments to aceustom our eyesight to the changed conditions. Passing onward we soon entered the "Columbian Areh," an almost perfect semi-cylindrical tunnel, seventy-five feet in length. From this we emerged into "Washington Avenue," a grand passage-way, 275 feet long, thirty feet wide and forty feet high. Near the farther end is "Falling Rock," a huge mass of limestone, resting partly on edge, $33 \times 16 \times 14 \frac{1}{2}$ feet in dimensions, and weighing, therefore, about 535 tons. Ages ago it fell from the roof and assumed its present position; one which earthquakes have failed to ehange, but which appears dangerous to the average visitor who passes beneath its towering form.

Within Washington Avenue a peeuliar pungent odor became noticeable, and inquiry as to its source brought information from the guide that in 1884 certain gentlemen from Evansville attempted to corner the onion industry of southern Indiana by buying up all the onion sets produced that season. Wishing a 
XI.

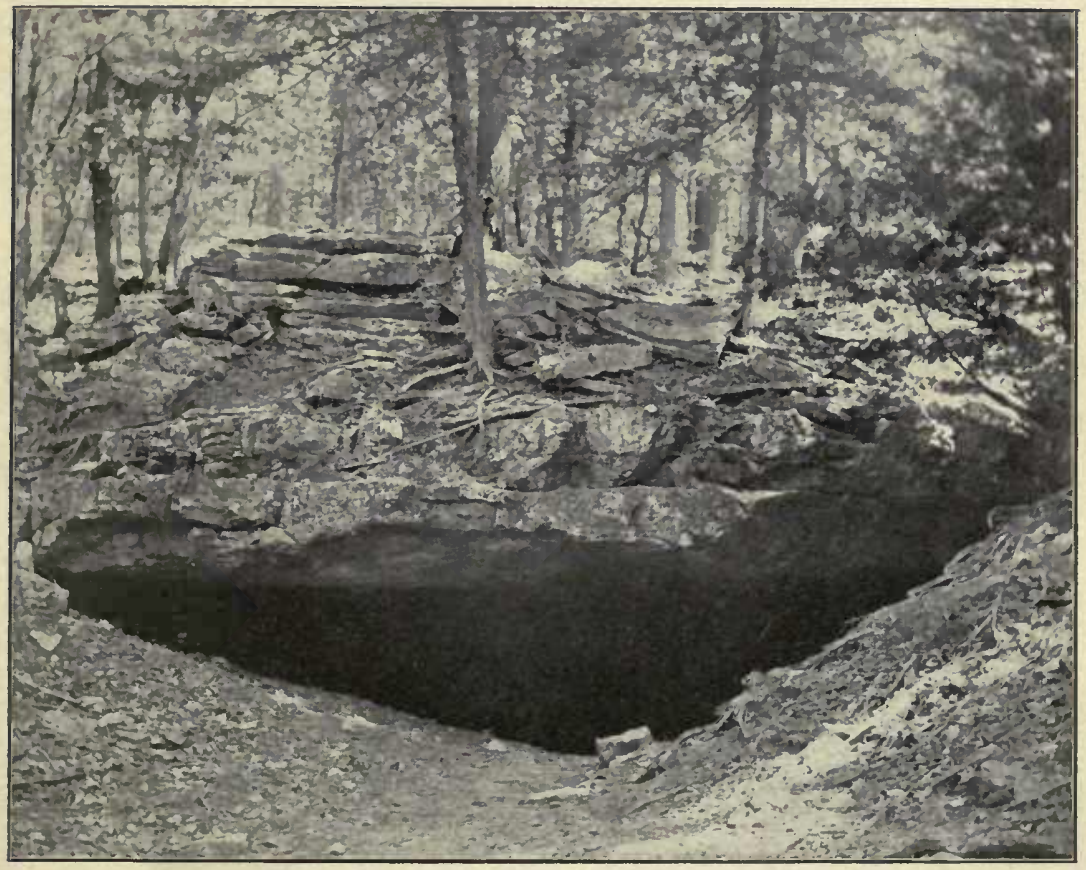

Mouth of Wyandotte Cave. 

suitable storehouse they rented room in the cave and deposited therein several hundred barrels of the sets. But, however suitable the pure cave air is for the preservation of sweet potatoes and other mild edibles, it.failed to act in like manner on the onions, and they soon began to sprout and grow. All were lost and were allowed to remain in the cave, their shriveled skins and pungent odor still reminding the visitor thereto of an attempted financial "comer," which failed to materialize. Another odor, more strong and disagreeable, especially in autumn and winter, was noted at this point or before. It was that of the exhalations of thousands of bats which make the cave a winter abiding place. Their faint squealing notes and flutter of wings were the only sounds that greeted. us from the depths of darkness beyond.

Passing under the falling rock and up a short declivity, we found ourselves in "Banditti Hall," fifty feet wide, forty to fifty high, and partially filled with rugged fallen stone, grouped in great masses on either side of the patliway. Stepping from slab to slab, we picked our way, until finally the guide called a halt, and lighting some "red fire," directed our attention to two outline figures formed on the ceiling above, by the scaling of the dark exterior from the whiter limestone. To one the name "Wyandotte Chief" was given many years ago by a correspondent of the Cincinnati Times, who wrote of it as follows: "We look up and see above the Falling Rock a mass of white limestone resembling the front of an Indian chief, with crown shorn to the sealp lock and fanciful earrings danğling from the ears. There he hangs, seem- 
ingly suspended, like Mahomet's coffin, keeping his dark and weary vigils, waiting to gloat over the death of some daring pale-face, crushed by the Falling Rock below." Upon the other figure, which resembles the facial characters sometimes seen in Punch and Judy shows, the fanciful name of "Betsy and I are Out" has been bestowed.

Banditti Hall is the closing portion of the common entry to both the Old and New caves. At its farther end the opening leading to the Old Cave is seen on the left, some twenty feet above the level of the floor, while about the same distance below, on our right, opens the doorway into "Fat Man's Misery," and the New Cave beyond.

Climbing a steep ascent into the Old Cave, we found ourselves at first in a passage-way ten feet wide and seven feet high, with the floor of ochery clay a number of feet thick, the walls of oölitic limestone, and the roof with here and there the more soluble portions dissolved until it resembles a coarse-celled honeycomb in appearance. Passing onward beneath "Pigmy Dome," we entered the "Continued Areh," a long passage-way, eight feet in height, ten feet wide, and with an occasional crystal of selenite glistening on the dry and dusty floor. From this we passed into the "Canopy," a circular room, twenty feet in diameter and ten feet high, with a smooth white roof. This is succeeded by another long, low passage, where stooping is necessary for some distance, and then we passed down through a narrow passage into "Lucifer's Gorge," forty feet deep, with precipitous, jagged rocks overhanging the sides. Up we climbed once more, 
fiom rock to rock, and, reaching another opening, crawled over a natural bridge, and on hands and knees crept for seventy-five feet through the "Grecian Bend." Finally we emerged into "Odd Fellows' IIall," one of the grand under-ground rooms for which Wyandotte is noted This we measured earefully and found to be ninety feet wide, 210 feet long and sixtyfive feet or more in height. The massive ledges of limestone forming the walls project toward the top, each layer a few inches farther than the one below, so that the ceiling is oval in shape, much narrower than the floor and appears to be hollowed ont by successive fallings of rock. Great masses of fallen rock partially fill the room, and tens of thousands of the little brown bat, Vespertitio subulatus Say, hung head downward from the ceiling. We extinguished the lights, and their low squealing notes became instantly hushed; the only sound which broke the death-like stillness being a continuous faint and lisping noise, like the ripple of water over a distant water-fall, due probably to the rustle of the wings of such as were flying through the Plutonian darkness.

The bats choose as a resting place that part of the roof where small portions have begun to flake, giving a certain degree of roughness, or small crevices, to which they ean cling. They cannot attach their claws

Cave Bats. to a smooth surface, hence from large portions of the roof of a room they may be entirely absent. In places where they find a suitable foothold they congregate so closely together that it is difficult to pull one from the midst of a group. On a low ceiling in Salt Petre Cave, near 
Wyandotte, an area one foot wide by one and seventenths feet long was measured, and the bats thereon were pulled off, one by one, and counted. Their number was 401 on the one and seven-tenths square feet. When pulled or knocked loose from the roof they fell to the floor, where they lay motionless for some time, and then began to flutter and crawl about, finally becoming lively enough to fly and find a new resting place.

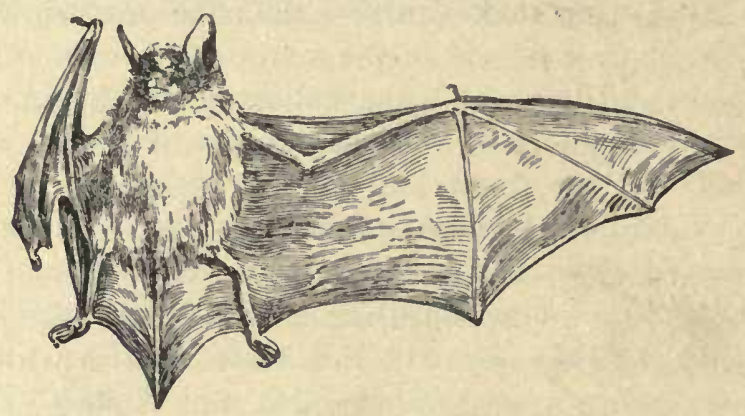

Fig. 34-Little Brown Bat.

Their squealing note was uttered only as we passed along, the light from the candles evidently disturbing those which had not yet entered their winter torpicl state. Two other sounds they seem eapable of making, one, the cry of a single bat in rapid, broken notes, - resembling the song of a robin in a minor key; the other, a noise somewhat similar to the short, quick alarm note made by the common ground squirrel, Tramias striatus (T.), when it espies some intruder on its domain.

They show a remarkable sense of direction in their flight, passing, in a darkness so profound that man 
ean see absolutely nothing, swiftly and unerringly through openings but a foot or two in diameter, without hitting the walls. The direction of 'flight seems to be, however, one of instinct or training rather than of reason, since when a loor was first put in an opening in the cave through which they hat been wont to pass in numbers, they flew blindly against it and were killed by thousands.

At Wyandotte, as elsewhere, the bats pass in $11 u m-$ bers into the deepest recesses, being found abundantly in the "Senate Chamber" and sparingly near "Crawfish Spring," two miles or more from the entrance.

As is well known, bats are erepuseular in halbit. They spend the day in darkness and the night in search of food. Such liabits have, in the course of ages, rendered their eyes excechingly small, their external ears large, their flight, like that of the owls and whip-poor-wills, noiseless. Several questions of interest, which to my mind are unanswered, arise regarding the eave life of these animals:

First.-In a cave where the temperature is $54^{\circ} \mathrm{F}$. the year round, how do they determine when warm weather has begun out of doors?

Secomd.-How do those which spend the days of the sunmer season in the eave determine the approach of dusk?

Third.-How do they distinguish, in the intense darkness, those portions of the roof which are smooth from those which are rongh enough to furnish a foothold?

On the right side and about fifty fect from the entrance to Odd Fellows' IIall is a pit-hole or per- 
pendicular eleft in the floor, through which an average sized man ean just squeeze himself. This is the opening into "Rothroek's Straits," a deep and narrow passage-way which connects with "Rothrock's Cathedral," a room of the New Cave.

From Odd Fellows' IIall we climbed by a rugged stairway and passed onward through narrow passages, and beside pits and chasms - the way ever seeming to grow rougher-the hills and valleys following each other in rapid suecession. In one place we descended fully fifty feet and from the bottom noted on our right the perpendicular walls of rock known as the "Cliffs." Over these in ages past a drapery of stalactites has been thrown in graceful folds, resembling a cascade which in mid-air his been congealed into stone, and is most worthy of its name- "The Falls of Minnehaha." Below these overhanging clifts is the gaping mouth of the "Pit"-a deep eavity leading by one drop fifty feet into space-as yet unexplored. From the foot of the Cliff's we made our way with difficulty up "Uncle Sam's Stairway" and then under the "Dead Fall," a large flat rock which lies at an incline across the passage, the upper edge supported by less than three inches of a thin rock projecting from the wall. From this point onward, for a distance of perhaps 1,000 feet, the way is a succession of steep elimbs and steeper descents, varied by an oceasional crawl on hands and knees and a final twisting of the body into shapes innumerable in order to effect the passage of the "Screw Hole," which forms the portal to the "Senate Chamber," the final room of the Old Cave. 

XII.

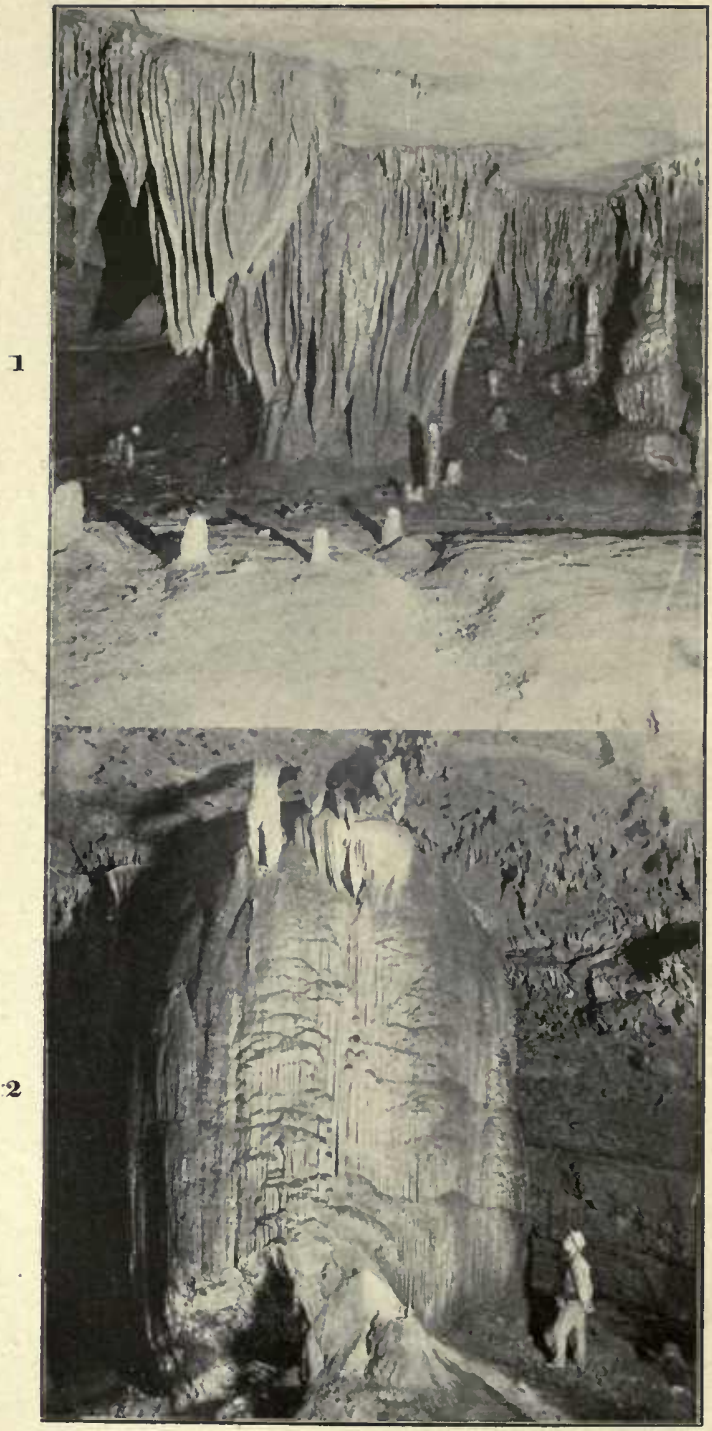

1. Tobacco Sheds, Marengo Cave.

2. Pillar of the Constitution, Wyandotte Cave. The opening at base of Pillar is a part of the Ancient Quarry. 
Collett described the Senate Chamber "as a vast elliptieal amphitheater, estimated at six hundred feet long and one hundred and fifty feet wide. The sides are built up with massive ledges of limestone, thinning and converging upward into a monster dome, with a flat elliptical crown fifty by twenty feet in diameter. The center of this vast room is piled up with a great mass of rocky debris fallen from the immense cavity above."

Other than the dimensions, this was an excellent description. Exact measurements show the room to be 144 feet long and 56 feet in width. The mass of fallen rock in the center, known as "Capitol IIill," is about thirty-two feet in height and is crowned to a depth of several feet with an immense mass of stalagmitic material. From the eenter of this mass rises from the top of the hill the grandest natural wonder in Wyandotte Cave-the great fluted column of erystalline earbonate of lime, known as the "Pillar of the Constitution." Perfectly cylindrical, seventy-one feet in circumference, and extending from the crest of the hill to the ceiling above, this enormous column exceeds in magnitude any similar formation in any known cave on earth. From the point where it first became visible in the dim light of our candles it appeared "like an immense spectral iceberg looming up before us, looking as if it had just arisen from the foaming waves of the ocean on a dark and foggy night." The entire column is composed of "satinspar"-a rather soft, white, striated mineral, the purest form of earbonate of lime. From one side, near the base of the eolumn, has been removed by the 
Indians, or some prehistoric race in ages past, humdreds of cubic feet of this material.

Up to 1877 it was generally supposed that the whites had made this excavation. In 1864 J.P. Stelle wrote of it as follows: "For fifty years the people of a civilized-aye, a Christian nation, have visited the Senate Chamber, not as almirers of the great God who has reared for himself such a magnificent temple, but as vandals. All the most interesting formations within their reach have been broken up or carried away; and even the great pillar itself has not been exempt from their attack, for an excavation has been made in its side which must have required days of hard labor, and from which large quantities of the purest white stone have been taken and scattered over the floor of the cave."

Prof. Collett, in 1877, found three glacial bowlders in the Senate Chamber, which, "from indications, such as wear and bruises, had been used as hammers or grinding pestles, and proved conclusively that that part of the Old Cave had been visited, if not oceupied, by men of the Stone Age."

Rev. H. C. Hovey, in 1882, first claimed that the excavation had been made by Indians "more than 1,000 years ago," and that the "round or oblong bowlders" of granite rock were the implements with which the ancient quarrymen wrought, being used "in breaking from this alabaster quarry blocks of a portable size and convenient shape."

H. C. Mercer, in 1894, visited the quarry and mentions the finding, by Mr. Rothroek, of a pick made of stag's antlers and states that "the proof of Indian 
work at the spot was satisfactory and of a character never noticed and studied before the discovery of the site."

These constituted the recorded observations of the quarry up to the time of my first visit in July, 1896. It was then noted that the quantity of spalls and flakes of the material thrown over the side of the hill was very great, and that no digging had been done to discover the nature or thickness of the debris on top of the hill, nor to more fully

An Ancient Cave Quarry. verify the statement that the work had been done by Indians. My time being limited, no excavations were made at this visit, but on a subsequent one, in Norember, 1896, I secured, the services of a workman and shovels and again visited the place. Careful measurements showed that above the debris a space eight feet long, six feet high and five feet wide, or 240 cubic feet, lad been quarried from the column. The top of the hill on which the column rests was found to be covered with an area 14 feet square of the debris, and through this, close alongside the base of the column, a trench was dug, eight feet long, three feet wide, and to the solid stalagmite beneath. It averaged four feet three inches in depth-i. e., at that point the debris or pieces of quarried material and other matter was that thick. A perpendicular section through this trench disclosed the following layers:

1. Ashes in a compressed, damp bed, with occasional flakes of stalagmite intermingled......... 14.0 inches.

2. Charcoal............................. 1.0 inch.

3. Ashes, with fiakes of rock $\ldots \ldots \ldots \ldots \ldots \ldots \ldots . .5$ inches. 
4. Rectangular flakes of stalagmite or satin-spar, varying in size from an inch or two square to pieces $8 \times 3 \times 1$ inches, or even larger, with occasional traces of charcoal intermingled ........ 28.0 inches.

5. Charcoal........................... 0.5 inch.

6. Flakes of stalagmite.................. 4.0 inches.

Six quartzose bowlders, weighing from three to six pounds, were found scattered through the mass which we threw aside, two of them within a few inches of the bottom. They were worn with use, and on the surface of two or three of them were depressions which appeared to be finger marks due to excessive use. At any rate, they must have enabled the workman to retain the rock hammer nore firnly in his grasp.

The remains of horus of five different deer, which mostly crumbled when disinterred, and numerous small bones, also too much decayed to ilentify to what animals they formerly belonged, were found at intervals in the trench.

By digging in a few other spots it was found that an area $14 \times 14$ feet, on top of this hill and at the base of the column, was covered to an average deptli of three and one-half feet with the particles of stone quarried. In addition to this, no less than twenty tons of the material had been pitched over the hill. Much, if not all, of this adclitional space was fornerly occupied by stalagmitic material, the base of the column flaring outward on this side, and when the space already mentioned as having been quarried above the debris is taken into consideration, there is little doubt but that more than 1,000 cubic feet of the stalagmite has been broken loose. 
In October, 1898, I visited the quarry for the third time, and dug in the debris for several hours. Eight additional bowlders of quartzose and many pieces of horn, crumbling bone and baked elay, were brought to light. Five wedge-shaped pieces of rock, one of flint, the others of limestone, were also found among the flakes of stalagmite. These had irregular notehes in their edges showing that they, together with the horns found in the debris, were most probably used as wedges to pry loose the pieces of satin-spar after the latter had been eracked by the stone hammers. Such horns and wedges of stone have been found in a number of eaves in Europe, where, ages ago, they were put to similar use.

A large quantity of wood must have been necessary to have produced such a bed of ashes as was found. The carrying this in over the seventeen rough hills and through narrow passes, through which one has to erawl and where more than a candle is a burden to the ordinary visitor, must have entailed a vast amount of labor and leads one to suppose that the material sought was used for a purpose deemed especially valuable. What that purpose was I have not yet been able to ascertain, there being few objects made of stalagmite among the "Indian relies" in any collection or museum in the United States.

Down the sides of the Pillar of the Constitution tiny streams of water are constantly trickling, and, spreading out upon the top of the hill, quickly evaporate, leaving behind their solid particles to make thicker the crust of so-called "alabaster" which covers the rough edges of the mass of rocks. This action 
will continue for thousands of years, until ultimately, by continued accretions, this hill will reach the ceiling and enclose entirely the wondrous pillar with its flutings and carvings, wrought in ages past by that magic graver-water.

Over the damp stalagmite forming the crest of Capitol Hill numerous specimens of the eave myriapod, Pseudotremia carernarum Cope, were rapidly crawling. Here also the little red harvestman, first noted in Clifty Cave, was found in unbers, and is probably utilized by the myriapod as one of its articles of food.

Back of the Pillar of the Constitution is the "Chair of State"-another handsome mass of stalactites and stalagmites-that extends from the top of the hill to the ceiling. Behind this on the right is the entrance to "Pluto's Ravine," the roof of whieh is studded with representations of sprigs, twining tendrils and branching corals, all wrought from calcite and "alabaster" in most exquisite fashion by the hand of nature. Many are broken, being the renıains of those removed before 1850, when the cave and its contents were esteemed but lightly by the owner, and no care was taken to prevent its despoliation by visiting vandals. Beyond this point one ean penetrate but a few yards in the Old Cave, the roof and floor coming close together, and barring further progress.

Much diversity of opinion prevails as to the distance between the Pillar of the Constitution and the mouth of the cave. Stelle, in his work published in 1864, says it is "just three miles." Both Collett and Hovey place it at two miles. Flint, in 1833, before it was thought necessary to exaggerate the distance, gives it 
as one and a quarter miles, and this is probably not far from correct. The rough character of the passage, the many steep ascents and corresponding declivities, added to the oppressive silence, cause persons unaccustomed to subterranean travels to thiuk the distance much greater than it really is.

TIIE NEW CAVE.

In 1850 a party from Fredonia, Indiana, observed that a current of air was passing from beneath a large, loosely placed, flat rock at the inner end of Banditti IIall, about 1,000 feet from the entrance of the cave. They succeeded in prying the rock loose and found a narrow descending passage, since known as the "Scuttle" or "Fat Man's Misery." This they entered and passed through, and for the first time white men stood in the "New Cave." The ceiling of the first room entered, which is called "Bat's Lodge," was then black with smoke. Fragments of charred hickory bark strewed the floor, while moccasin tracks, now entirely obliterated, were plentiful. Hundreds of poles of sassafras, papaw, lin, and other soft woods were

The Short Route. found both in this room and in that portion of Rothrock's Straits nearest the New Cave. None of these poles had been eut with a sharp instrument, but all had been twisted from the parent stem or hacked therefrom with dull stone axes. On the left side of the room was found a sloping bank of earth and sand in which bark, sticks, leaves and bunches of twisted grass were plentiful. Digging into this bank in 
November, 1896, numerous pieces of bunch grass, the inside bark of lin and poplar trees and short stems of weeds were found. These were, probably, remnants of a store of fuel resorted to when the torehes waned or a relight was needed.

Bat's Lodge is a low room 70 feet long, 21 feet wide and five to six feet high, the walls and roof begrimed with the smoke of ancient fires, and the floor a mixture of dry, dusty earth, with here and there a piece of fallen limestone. From the mouth of the cave to this point is a gradual descension, and barometer measurements showed the floor to be 150 feet lower than the Cave Hotel. Beyond this room the roof so closely approaches the floor that, in 1856, "Counterfeiter's Trench" was dug through the earthy deposit which had silted up the way. Through this trench we easily passed and found ourselves at the foot of "Rugged Mountain," a mass of broken pieces of limestone, thirty feet or more in height, which fills the greater part of a large room. Climbing this mountain we reached the "Rotunda" or upper portion of the room, 52 feet one way by 90 feet the other, with the roof $\mathbf{1 6}$ feet above the top of the mass of rock. Around the edges of the room are numerous deposits of fine, white, needle-shaped crystals of epsom salts (magnesium sulphate) encrusting the rocks and sparkling like frostwork in the light of our candles. They seem to exude from a porous matrix of magnesian limestone, and if not disturbed often attain a length of three to five inches. Passing down Rugged Mountain on the farther side we entered "IIanover Chapel," where numerous artificial piles of heavy stones, dedi- 
cated to some Greek fraternity or college elass, stand as monuments to the muscular ability of visiting students in days gone by.

A short distance beyond this point we climbed again and entered the "Coon's Conncil Chamber," a circular room 35 feet in diameter. Here two bands of blackish flint or jasper abont four inches in thickness, first noted in descending Fat Man's Misery, are very prominent around the walls. A few yards farther on we came to "Delta Island," an uneroded mass of limestone, 50 feet long by 20 feet wide, on either side of which one may enter that part of the eave called the "South Braich," which forms the greater portion of the Short Route.

Between Banditti IIall and Delta Island a small Tineid moth, Blabophanes ferruginella Hbn., closely related to the common clothes moth, occurs in numbers. Its presence in such a place is worthy of especial notice since no other instance is on record of a member of the order Lepidloptera, to which belong the moths and butterflies, being an inhabitant of caves. This moth was found in May, July and November, close to the floor and always in the

A Cave Inhabiting Moth. vicinity of the decaying remains of bats and other refuse matter upon which its larva feed.

It is one-fourth of an inch or more in length, and its wings expand about two-thirds of an inch. On the heal is a tuft of rust-red hairs. The fore-wings are grayish-brown, with a violet tinge in fresh specimens, and a broad buff margin along the inner edge, which, in repose, forms a conspieuous buff stripe along the back. 
The pupal cases are dark gray, densely felted, and one-fourth of an inch or more in length. They were found attached to small projections of the wall, close to the floor, or on the under side of stones which rested loosely on the floor.

The moth seldom flies, but crawls very rapidly or leaps short distances, when disturbed. It was first deseribed in Europe, where it occurs among pelts and furs. Its presence in Wyandotte Cave can only be accounted for by its accidental introduction on the clothing of guides or visitors. As yet it shows no difference in color or structure from open-air types of the same species, but it is not unreasonable to suppose that in years to come there may be perceptible modification in these respects, as has been observed in other cave inhabiting forms.

The introduction of this European moth into a eave like Wyandotte, and its rapid adaptation to the peculiar environment there found, is an excellent proof of the now commonly accepted theory that all cave animals are but the descendants of seeing forms, which in the past, have thus accidentally found their way into caverns.

In the same region in which the moth occurred were numerous specimens of a small dark-brown gnat or fly abont one-twelfth of an inch in length. It was found to be new to science, and has since been described as Limosina tenebrarum Aldrich. It occurs beneath stones, in the vicinity of the remains of bats which are killed in numbers by the cats which frequent the cave. This insect has the power of leaping several inches when disturbed and seldom uses the wings in endeavoring to escape. 
Passing to the right of Delta Island we entered the "Dining. Room," forty feet wide, ten feet high and seventy feet in length, the monotony of the limestone walls being relieved by several bands of jet black flint, about three feet apart. One of these bands has the flint in quadrangular blocks, while in the others it is in nodules, many of which are several inches in diameter. Sometimes these nodules resemble in form a geode, and when broken show a crystalline center, the siliceous particles having collected and crystallized about a common nuclens.

Leaving the Dining Room we proceeded through a short pass to the "Drawing Room," whose dimensions are abont $25 \times 10 \times 60$ feet, and from this into the "Junction Room." From here three passages diverge, one to the left through "Creeping Avenue," one straight ahead to the right of the "Continent," the latter being a vast mass of uneroded limestone, around which the two branches of the old subterranean river formerly flowed; while the third passage, known as the "Cut Off," turns aloruptly to the right and merging into a short, tortuous, descending passage-way, leads out into the main cave between Comnterfeiter's Trench and Rugged Mountain.

Taking the passage past the right of the Continent we entered the "Council Chamber," a spacions room, $15 \times 50 \times 100$ feet, which, like IIanover Hall, contains many artificial monuments, erected in the past by enthusiastic visitors who knew no better way of proclaiming to the world the fact of their existence. Narrowing again, the main passage continues for perhaps 200 feet, when once more it expands into another 
of those grand subterranean rooms which characterize Wyandotte Cave. This has been dubbed the "IIall of Representatives," accurate measurements showing it to be $100 \times 160$ feet, with the eeiling 35 feet above those nasses of fallen rock which in the past filled the space of the broad overhanging dome. Where these large rooms oceur, the old river which formed the cave must have flowed over a softer portion of rock and eroded or dissolved a great basin in the bed or floor of the chanuel, perhaps escaping by an outlet now hidden. In time the roof, no longer self-supporting, came tumbling down and partially filled the basin. From most of the rooms, as from the IIall of Representatives, one must climb twenty or more feet to the mouth of the passage leading onward.

Beyond this hall we descended the "IIill of Science" into a lower portion of the cave, from which a low, wet side passage turns to the right. II ere for the first time we encountered mud, and the floor of the "No. 10 " passage, as it is called, is for the greater portion of the year covered to a depth of several inches with standing water. We next arrived at the junction room, called "Jordan's Wait," where that noted scientist, Dr. D. S. Jordan, once had several hours for cool reflection, having been left in total darkness by the accidental extinguishing of a candle which he had no means of relighting. This junction room is located at the foot of the Continent, where the passage which turned to the left around that body, meets the one through which we had traveled.

Proceeding onward, we entered the most sonthern arm of the cave, and, passing through a damp-floored 
passage, 150 feet long by thirty feet wide, we found ourselves at the foot of a slippery hill on top of which is one of the most handsome formations in the cavethe "Throne and Canopy." The former is composed of a circle of rounded stalagmites cemented together and having the general appearance of a throne of state, while at a distance of six feet above is a curtain of broad, leaf-like stalactites draped in a graceful semi-circle and attached to a projecting mass of crystalline limestone. From a crevice or seam between the massive layers forming the walls the water has, for ages, seeped; then evaporating, has produced these charming natural wonders and given a slippery coat of stalagmite to the surface of the hill below.

In the "Spring of Deception," close by the throne, were noted in July numerous specimens of a small shrimp-like crustacean, .Crangonyx packardii Smith. It swims very rapidly, jerking itself hither and thither throngh the water in a zigzag course, and is extremely difficult to capture. In November the water in this spring had disappeared and the bottom was covered with very soft, sticky mud. In this a number of small holes, resembling the burrows or pits of angle-worms, were noted. Each had numerous particles of dry, sand-like grains of mud about the mouth. The pits were probed and cut out with a knife, but no living form could be found. They were probably formed by the small Crangonyx, of which no trace remained. The same crustacean occurs in numbers in Crayfish Spring near the end of the Long Route.

Beyond the Throne is a long stretch of partly explored avenues and side branches, through which 
visitors are not often taken, there being therein but one scene of more than passing interest. This is "Helen's Dome," so named by that Nestor of cave explorers, the Rev. II. C. Ilovey, in honor of his wife. To reach it one must pass through "General Scott's Reception Room," 75 by 100 feet in dimensions, and then by stooping and crawling through a narrow passage into "Diamond Avenue," where nature asserts her power to work miracles of beauty from cheap materials, transforming gypsum and epsom salts into lustrous erystals which sparkle on the walls and glisten from the floor. Leaving a branch to the right, we turned to the left, and passing cautiously beneath a poised mass of fallen rock, which seemed ready to fall at the slightest touch, we entered a large opening midway between roof and floor, and a few feet farther on found ourselves at the foot of a great cireular pit some twenty feet in diameter and extending upward through the solid limestone for eighty feet or more.

This was Helen's Dome, and when the guide kindled his "red fire," and the light therefrom revealed the rugged, water-worn carvings of the sides, and the pendent stalactites, which far above gleamed and glistened from their inaccessible heights, we with one accord voted it the wildest and most romantic bit of scenery which the cave possessed.

Retracing our steps to Jordan's Wait, we took the right branch around the Continent. This led us on through a low passage known as "Purgatory," 140 feet in length, its floor of yellow ochre, with here and there a handsome erystal of selenite; its roof of white limestone, with many fantastic grooves and carvings 
wrought in days of yore by the slow but powerful energy of flowing water.

Emerging from Purgatory we assumed once more a standing posture, and found ourselves in "Calliope's Bower," where many stalactites grace the walls and ceiling. From thence we passed into "Whispering Gallery," where the floor resounded to our tread and the low tones of our yoices were echoed back and forth from the arched sides in a mamner similar to that noted at the bottom of a deep and empty cistern. Then came the "Palace of the Genii," where these gods of fable dwell beneath a roof spangled with glittering crystals of calcite and gypsum. The "Pillared Palace" follows, and therein is found a wealth and profusion of cave formations such as no words of man can properly picture. Pillars, stalagmites and stalactites abound of every conceivable form which the fancy can suggest. Many of the stalactites are no larger in diameter than a lead pencil and are curved and twisted in a unique and grotesque mamner seen elsewhere in no Indiana cave. This bent and twisted condition is doubtless due to the varying eurrents of air which pass through portions of the cave and force the tiny drops of water on the end of the stalactite first to one side and then to the other of the tip. The air of Wyandotte flows outward, or toward the mouth, in summer, and inward, or toward the depths of the cave, in winter. This difference in direction of flow can but have its influence on the formation of such slender structures as those above mentioned.

Emerging from the Pillared Palace by an ample doorway, flanked by handsome pillars of calcite, we 
found on our left a room where strata of jasper nodules abound in the walls and where numerous chips and splinters of jasper are abundant on the floor. Rev. H. C. Hovey first called attention to the fact that the supposed "bear wallows" of this room are depressions where, in the treacherous light of bark torches, ancient workmen had reclined while they worked down to partial finish the desired blocks of jasper. Numerous fragments of charcoal and large heaps of chips of jasper were about each depression, but, though careful search was made, no partially finished article of jasper was found. The fragments were mostly oblong, with the faces parallel, their dimensions being, on an average, about $4 \times 2 \times \frac{1}{2}$ inches. Several quartzite bowlders have been found in the room, where they were doubtless carried to be used as implements in splitting the blocks of jasper or in loosening then from the walls.

This ancient quarry-room is succeeded by "Creeping Avenue," where the roof, for a distance of 172 feet comes down to within two and one-half feet of the floor, and progress is possible only upon the hands and knees. According to the guide, the dryness of this portion of the cave is slowly increasing and, as a consequence, epsom salts (magnesium sulphate) is becoming more abundant. Where the cave is dimp with dripping water, stalactites and other forms of calcium carbonate are abundant; where the dripping has ceased but the walls still give off more or less dampness, calcium sulphate or gypsum is the prevailing formation, and where perfectly dry the epsom salts alone are being produced. 
The tiresome crawl through Creeping Avenue finished, we stood erect once more in the Junction Room at the head of the Continent and the exploration of the Short Ronte was at an end. The length of the portions passed through was estimated to be about as follows:

Fat Man's Misery to Delta Island ............... 1,200 feet. Delta Island ria Creeping Arenue to Iovey's Point .... 2,400 feet. Jordan's Wait via House of Representatives to the end of

the Cut Off. ......................... 2,000 feet.

Total ..........................5,600 feet or $\overline{1.06 \text { miles. }}$

In going through what is known as the "Long Route" in Wyandotte, we passed from the mouth of the cave to Delta Island over the same way as described above under the "Short Route." At Delta Island we turned to the left and traversed the "Sandy Plain," a passage about 350 feet long, twenty-five feet wide and six to ten feet high; the floor of which is covered in places to a depth of several feet with sand deposited

The Long Route.

by the ancient cave river. At the end of the Plain we found ourselves at the foot of the "Hill of Difficulty," which is but a mass of fallen rock, forming, as it were, a foot-hill to the grander "Monument Mountain" which lies beyond. On the left, in climbing this hill, the guide pointed out the exit of Rothrock's Straits, that narrow and deeper passage connecting the Old and New caves.

Reaching the top of the Hill of Difficulty, we were within the confines of the largest under-ground room yet known to man-“" Rothrock's Grand Cathedral." 
Before us in the dim eandle light was a towering mass of fallen rock, thrown together in most glorious confusion and piereing the gloom above us for $\mathbf{1 3 5}$ feet. Following the guide and clambering from rock to roek, we made the ascent by easy zigzags and reached a point near the summit with but little fatigne. The crest of Moniment Mountain, like that of Capitol Hill in the Senate. Chamber of the Old Cave, is covered to a depth of several feet with an encrustation of stalagmitic material. This is slowly increasing in thickness by the accretion of solid particles of limestone left by the eraporation of the water which is constantly trickling in a small stream from the roof above. The uppermost ten or twelve feet of the mountain is very smooth and slippery, and one has much difficulty to keep his footing while climbing to the very pinnacle, from which projects a brownish-yellow stalagmite 6.5 feet in height and 3.7 feet in circumference. Below this a short distance, and on the opposite side of the mountain from the entrance, is another stalagmite, 6.8 feet in height by 5.2 feet in eireumference, while but a short distance away is a third and shorter one. The last two are composed of spotless white, almost translucent limestone, and are known as "Lot's Wife and Daughter."

Crawling over the damp surface at the foot of these stalagmites, as well as on their sides, were numerous specimens of cave myriapods and harvestmen. A few examples of a small, semi-blind psevido-scorpion, or chelifer, Chtonius packardii Hagen, were also obtained from the surface of the damp rocks at this place. It moves slowly along with its front legs or 
XIII.

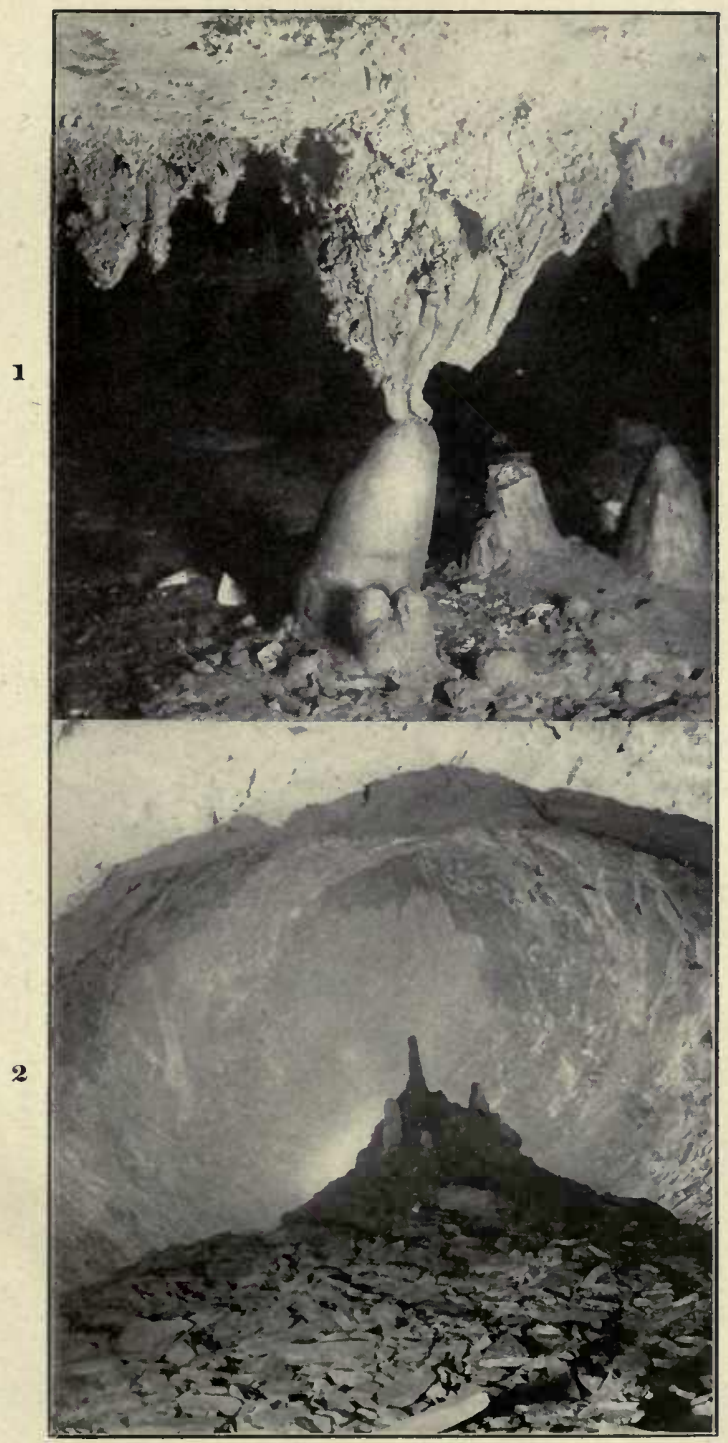

1. A Pillar in Pillared Palace, Wyandotte Caye.

2. Rothrock's Cathedral, Wyandotte Cave. 

chelæ held in the air and, being less than one-tenth of an inch in length, is very likely to be overlooked unless especial search is made for it. It has been taken in Mammoth and other Kentucky caves, and varies much in regard to the development of the eyes; some, living without the caves, having two eyes with the cornea as usual; others, within the caves, having no cornea, but retaining the silvery dot indicating the retina, and still others being totally blind.

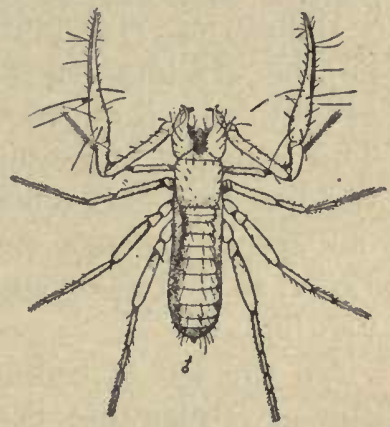

Fig. 35-Cave Pseudo-scorpion. (After Hubbard). (Enlarged 71/2 times.)

Forty or more feet above the crest of Monument Mountain expands "Wallace's Grand Dome." The center piece of this is, "a sinooth, elliptical slab of oölitie marble, 60 feet long by 30 wide, finely contrasting with the darker limestone, from which it is divided by a deep rim, fringed with long stalactites, curling like leaves of the acanthus."

Leaving three candles burning a few feet below the summit, we descended the opposite side, and, extinguishing our lights, as soon as the eye aceustomed itself to the surroundings, beheld a scene as grand as human mind can faney-"an indescribable vision, as if an opening had been made into the reahns of supernal splendor." The scene is known as the "Cathedral by Moonlight," the faint candle light refleeted from the white, oval dome appearing like a halo of moonlight over the dark crest of the mountain, while the 
three stalagmites stood like spectral visions surmountirg the dark and rugged ledges which rose between us and the source of the faint light above.

Relighting our candles, we found a few feet farther on, the "Sulphur Spring," the trickling waters being caught in a shallow cavity of a round stalagmite. This is one of the dining places of visitors, and from the near-by moldy remains of food were taken numerous specimens of a small black fly, Phore nigriceps Loew, as well as several mites, and the common cave "springtail."

Tho the left of Sulphur Spring, in the smooth and slippery stalagnite, is an opening thirty inches wide by fifteen inches high. This is the famous "Auger IIole," which, when discovered and enlarged in 1850 , admitted the explorers to an extensive area of unknown passages and rooms-yet none so grand as those already noted.

Through this opening we made our way, some head first, others the reverse, all finally landing safely about ten feet below in a damp room known as "Lilliputian Hall," along which, by stooping, we found our way into "Spade's Grotto," once evidently connected with Rothrock's Cathedral by a passage now hidden by fallen rock. From thenes, in divers manners, we descended "Slippery Hill" and found ourselves in the "Hall of Ruins," a passage 150 by 30 feet, with an average height of perhaps eighteen feet. This leads into the "White Cloud Room," probably 350 feet in length, where the roof and walls are enerusted with an eflorescence of gypsum, resembling, after a fashion "billows of fleecy clouds." Beyond this room we 
passed through the "Journal Office," near the farther" end of which is the "Bishop's Rostrum," a high platform of rock, $8 \times 10$ feet in dimensions, from which portions of many a sophomoric oration, as well as several divine dissertations, have, in the past, been delivered.

"Calypso's Island" is a large mass of uneroded limestone, on both sides of which the old cave stream has forced a passage. The floor of the passage to the left of the "Island" resounded our footsteps in a pecnliar echoing fashion, suggesting the presence of a lower passage beneath our feet. The two wings of the main passage converge at the farther end of Calypso's Island and expand into the "Cærulean Vault," a room 40 feet wide by 20 feet high. 'This narrows into "Rugged Pass," from the side of which a narrow cleft in the rock leads by an ascending, very low and tortuous passage, known as "Worm Alley," into "Milroy's Temple."

This is a room $100 \times 150$ feet in dimensions, around the upper edge of which are found some of the most handsome formations in the eave. One of them is a row of musical stalactites, broad and thin, on which a melody can be played hy a skillful hand. There are also ereamy stalactites, vermicular tubes strangely intertwined, convoluted roots, mural gardens and galleries, gay and grotesque. A deep pit, the bottom of which is sixty feet or more below the entrance, is found in one side of the room, and the sound of a stream of water falling from a cleft in the ceiling and splashing on the rocks at the bottom of the pit was a pleasing break to the monotonous silence of the vast rooms through which we had come. 
Onee more bowing our heads to the inevitable, we crawled, squirmed, rolled and pulled ourselves throngh Worm Alley baek into the main cave. Following our guide, we passed on through "Josephine's Arcade," where a silhouette of the "Cave Queen," formed by the falling away of the white gypsum from the darker limestone, greets us from the wall. "Indiana University Chapel" and the "Ball Room" sueceeded and brought us to the "Junction Room" of the Long Route. Here the eave forks, one branch leading to the south-west and the other continuing northward to "Crawfish Spring" and "Wabash Avenue." Taking the latter, we found it to be made up of a succession of halls, galleries and avenues, each with its own fanciful name and pleasing peculiarities, yet no place worthy of more than passing notice when taken in contrast with the grand scenes already described.

In several places between the Junction Room and Crawfish Spring the first explorers of the Long Route found tracks of a small party of Indiaus who had wandered to and fro in that region. They had evidently entered by some opening as yet unknown; since the Auger Hole, now the only means of entrance, was, when first discovered, entirely too small for the passage of a man. It is better, in my opinion, to consider that their means of entrance and exit has since been covered by fallen rock or, like that through Fat Man's Misery, was hidden purposely by those ancient explorers, than to take the ground, as has been done, that the tracks were made 1,800 or 2,000 years ago, before the opening of the Auger Hole was so nearly elosed as to prevent the passage of a man. These 
moccasin tracks were seen and noted by many of the early explorers, and low stone walls were put around them for protection, but the tracks have since been almost entirely obliterated by persons who, unmindful of the warnings of the guides, stepped over and upon them.

Crawfish Spring is formed from a small stream which flows through a cleft in the rock, and from it a trickling rill meanders on beneath the edges of the jutting walls to be soon lost to view beneath the roof which a few rods farther on eomes down to meet the floor. Above the spring is the passage known as Wabash Avenue, which extends for several hundred yards in a north-westerly direction where it forks into a number of low and muddy branches.

Within the waters of the rill were several specimens of the blind crawfish and numerous examples of two other smaller crustaceans, already mentioned. About the margins of the spring and stream and on the mud flats lying beyond, were secured a number of the true cave beetles, Anophthalmus tenuis Horn. Single speci-

\section{A Blind}

Cave Beetle.

mens of this inseet had previously been taken in several of the caves visited, and in Wyandotte it had been found about the Throne and on top of Monument Mountain. It is found only in remote parts of the caves in which it oceurs, and is always crawling rapidly over mud, sand or rocks in damp localities. It is a small, light-brown species, with no vestige of eyes, and appears wholly unaffected by the light of a candle when the latter is held within a few inches of it. 
Like other Carabids, these small blind beetles are supposed to be carnivorous. In Wyandotte specimens

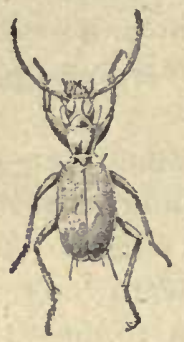
of mites, spiders, spring-tails and harvestmen were taken in the same locality as the beetles, and probably furnish the latter a scanty supply of food.

Retracing our steps to the. Junction Room, we took the sonth-west passage, the first room entered being the "Frost King's Palace," eight feet high and Fig.36-Blind Beetle. (After Packard.)
(36-) twenty wide, where every object, great (Enlarged 3/2 times.) and small, is encrusted with sparkling crystals of gypsum. To one side is the "Bridal Chamber," and therein are found some of the finest of the gypsum rosettes for which the cave is noted. Several of these are four and a half inches in diameter, the slender crystals forming them having protruded from the pores in the magnesian. linestone, and then, uniting into fibrous masses, have curved inward to form the oulopholites, or curl-leaved stones, each of which bears a close resemblance to a true rosette.

The "Ice House" is a rough-floored room where dripping water from the roof has covered the surface of the rocks with a film or coating of the thinnest and most translucent of calcite, resembling ice. Leaving the opening to the "Unexplored Regions" on our left, we descended from the Ice Room into "Morton's Marble IIall," 1,100 feet in length, the sides and walls of which "are completely dressed in snowy whiteness, equaling the brightest marble halls of dreamland, song or story." Occasional nodules of jet-like flint 
are seen exposed along the walls and ceiling, and here and there are examples of the gypsum rosettes already mentioned. Beyond the Marble IIall is "Queen Mab's Marble Garden" and the "Fairy Palace," both of which have their walls eovered with a gypsum effloreseence which has assumed the shapes of flowers, leaves, sprigs and fanciful forms of many kinds. From the end of Fairy Palace, 1,750 feet from the Ice House, diverge several low passages which visitors seldom enter, and from here we started on our return to the entrance of the cave.

The distance from Delta Island to Crawfish Spring, including Milroy's Temple, was estimated to be about one and four-tenths miles, and from the Junction lioom to the end of Fairy Palace, about one-half mile. The total length of Wyandotte Cave as traversed by the visitor who takes all three routes is, therefore, about as foilows:

Old Cave. 1.25 miles. Short Route from Fat Man's Misery onward ........ 1.06 miles. Long Route from Delta Island onward ........... 1.90 miles.

Total ................................ 4.21 miles.

These distances are for one way only, and if the routes are passed over on different days, the distance from the entrance to where each begins must be added to that above given.

With two of the guides I passed through Rothrock's Straits in November, 1896. Dropping ourselves through the narrow eleft in Odd Fellows' Hall, we crawled down an angling passage over a mass of rough rocks and into a low room almost filled with 
fallen rocks. From this we crawled still farther down, climbing over great blocks of limestone and making our way beneath others partly loosened from

Rothrock's Straits. the roof, until finally we reached the very bottom, probably seventy-five feet below our starting point. Here we found another low room, with an earthen floor, which had great cracks running through it in every direction, but with no signs that water had been present for eenturies. From this a very low passage makes its way to near the Coon's Council Chamber, but there is no exit into that room. Retracing our way we took another route, and after much creeping, wriggling our way through dust, bumping our heads on the low ceiling, and with nothing in the way of interest to repay us for our trouble, we finally emerged on the side of the Hill of Difficulty, and knew by personal experience that the Old Cave and the New are connected, and that the passage-way between them is a very rocky road to travel.

The entrance to the so-ealled "Unexplored Regions" of Wyandotte opens from the Ice House, beyond the Junction Room of the Long Route. These regions

The Unexplored Regions. have been partly explored by guides, but visitors seldom pass within their portals. Washington Rothrock, the oldest and best known guide of the cave, has been through them several times as far as Rothrock's Island. The formations therein are said to be wondrously beautiful and more numerous than in many of the more thoroughly explorerl regions of the eave. A large series of specimens were obtained from some 
of these passages in 1893 for the World's Fair. A number of the larger passages of the Unexplored Regions have not been penetrated as far as man can go, and some future explorer may, perhaps, find formations more beautiful and scenes more grand than those oecurring in the better known portions of the cave.

\section{LITTLE WYANDOTTE CAVE.}

The entrance to this cave is situated at the bottom of a sink-hole distant about 300 yards from the front of $\mathrm{W}$ yandotte Cave Hotel. The floor of the cave is about 20 feet below the bottom of the sink, and descent is made by a ladder placed in a well-shaped opening about three feet in diameter.

In the crevices on the sides of this opening were several eave salamanders, and also a number of the large hump-backed cave erickets, Ceuthophilus stygius (Scudd.). This insect reaches a length of one and a fourth inches, and has antennæ, or feelers, more than four inches long. It is not a cricket, but belongs to the same family as the katydid, A Cave Cricket. though in general appearance it differs widely from that common insect. It was found in the entrance of Wyandotte Cave, and in several other of the smaller eaverns of the vicinity, but in no instance farther back than 250 feet from the mouth. The adults seem to be more or less gregarious, and, in one instance, more than 20 were found in a small eranny in the wall. They were grouped in a circle, in a space abont six inches square, with their long antennæ pointing toward the center of the circle, 
and appeared to be holding a conference or cricket convention.

They were never seen on the floors of the eaves unless they leaped there when disturbed, but were found resting on the sides of small projeetions and in cavities of the walls or roof. If a lighted candle were held elose to them they paid no attention to it, but were very sensitive to its heat and to touch. When disturbed they leap with agility, sometimes to a dis-

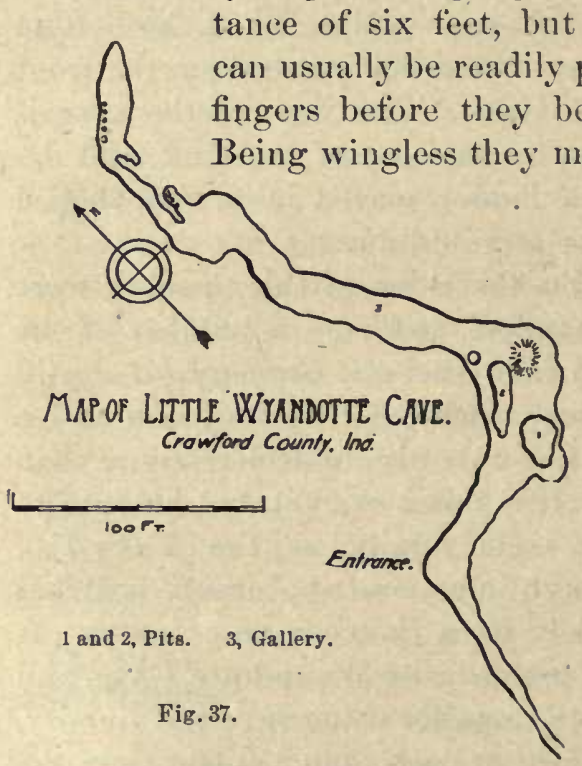

hand passage can be followed only about seventy-five feet, when it beeomes too small for farther progress. It contains no features of interest except a few stalactites.

The left hand passage was found by actual measurement to be 340 feet in length. Passing "Pompey's 
Pillar," a large stalagmite, the first room entered was "Cleopatra's Palace," where there are hundreds of fine stalactites, which show grandly in the glare of the magnesium light.

Beyond this room two pits, said to be 60 feet in depth, shut off the farther side of the cave. A narrow partition of slippery stone separates the two and serves as a bridge to cross the ehasm. On leaving this natural bridge, we made our way along the side of a steep ledge that skirts the left hand pit, and then passed around a gigantic fallen stalactite, which has been kept from rolling into the pit only by a friendly stalagmite against which it rests. Climbing a steep slope in which notches have been eut to serve as footholds, we entered a gallery, one side of the expanding mouth of which serves as a balcony above and partially around the deepest pit. On and above this balcony is a collection of cave formations of exceeding beauty and grandeur. A stately, fluted pillar, with its base expanding in broad-leaved masses of dripstone, thus forming a heavy folded eurtain along the edge of the pit, is the giant of the group; while most unique of all is the "Corinthian Column," ten feet high and less than three inches in diameter-a slender shaft of translucent, snow-white satin-spar reaching from floor to ceiling. A number of fragile tubular stems were clustered about the head of this pillar, each with a terminal drop of water, which glistened like a well cut diamond in the light of our eandles. Entering the gallery we wandered on, "beneatlı a ceiling fretted with glistening pendants, amid pillars and pilasters, flying buttresses and interlacing arches, with liere a 
cascade in mid-air transmuted into stone, and there a sculptured cell amid clustered columns." The cave finally ends in "Peri's Prison," where a narrow side gallery is separated from the main passage by a row of slender pillars, each but a few inches from its neighbor. All in all, Little Wyandotte is well worthy of visitation, and he who wishes to see the beautiful and at the same time experience a sense of the perils attending cave exploration, should enter its bounds, eross the narrow bridge between the yawning chasms, and climb the slippery hill to the lovely gallery beyond.

$$
* *
$$

Other caves there are in southern Indiana which we would gladly have explored and deseribed hatd our time permitted. No two in the State are alike. Each is noted for some peculiar formation, room or passage which it possesses. In each and all can one see the results of the action of water-that greatest of nature's solvents and abraders, soft to the touch, gentle to look upon, its work of a day, a year, a century upon the solid limestone not appreciable to the eye-yet by slow, unceasing action through the eors which have elapsed since that work began, it has carved every room and passage, constructed every pillar and stalagmite existing beneath the surface of southem Indiaua. 


\section{A DAY IN A TAMARACK SWAMP.}

A half-day rather, for the other half was occupied in reaching the swamp, and half of the night in returning therefrom, so that part of the story must be of some of nature's objects noted on the way and the thoughts that they engendered.

The $6: 20$ train on the "Logan" road was almost ready to pull out on a recent Saturday, when, after a brisk walk of half a mile through the cool enlivening air of early morn, I reached the Union Station. The platform was thronged with prospective passengers, hound for the four corners of the globe and starting with the coming of the sun. All was bustle and noise but we were soon off to the quiet prairie region northeast of Terre Haute.

No frost as yet had seared the vegetation and the late planted corn was ripening rapidly; its partially green, partially yellow leaves glistening with the dew of the night. 'The many wild plants growing along the railway are to me, when triveling, objects of exceeding interest, but on this day but few were at first seen, the ruthless hand of the section boss having caused their early downfall. Occasionally a sunflower or stalk of golden-rod, which in some unknown way had escaped destruction, waved its flowers in defiance as we were whirled past; or the bright blue of the wild morning-glory and brighter blue of the lobelia 
seemed trying to excel the hue of the sky above them.

Just over the boundary fence, however, beyond the jurisdiction of the devastating wayside mower, grew in many places wild asters in profusion. Our native asters are distinctively flowers of autumn. They do not begin blooming until mid-September, and, as late as December 1st, can often be found in some protected nook, the last wild flowers of the dying year. The

- wild asters vary in color from a pure white to a deep blue. One or two possess a pinkish tinge but none are red or yellow. Our snnflowers and golden-rods furnish sufficient of the latter color; while the scarlet leaves of the maple, black-gum and dogwood, together with many of our wild fruits, paint amply red the autumu landscape.

The asters, sunflowers and golden-rorls comprise neally one-half of the Indiana members of the great Composite family - in number of species the giant family of the flowering plants. In the arts the nse of these plants is unknown. But the lover of nature, whose eye is ever on the search for the pleasing and the beautifil, blesses their existence; for, their liues absent, our autumn scenery would lose much of the charm due to its varicty of color.

Beyond the prairie came the uplands of Parke and Montgomery counties where the Kentucky blue-grass and the sugar-maple, two of the most attrictive and valuable wild plants known to man, reach the acme of their perfection. The limestone soil of this "bluegrass region of Indiana" furnishes exactly the food needed to make the sugar-maple, Acer sacchurum 
Marsh, a perfect tree. Great groves of them, each tree so isolated from its fellows as not to shade too densely the grass beneath; each with its branches stopping short at a uniform height, ten to twelve feet from the ground, form vast forest sheds which all summer long furnish plentiful shade to those herds of fat eattle which are the pride and wealth of the owners of the land.

Farther north the "Logan" runs through a flat, upland country where the bitter-nut or swamp hickory, the beech with its smooth lichen-covered bole, and immense numbers of gigantic bur-oaks, aloound. At intervals clumps of that handsome shrub, the black alder or winter-berry were seen, its bright-red fruit giving an exceeding vividness to the dense green of the surrounding forest, which was as yet untouched by that prince of painters, Jack Frost.

Then the prairie with its characteristic flora once more appeared; and finally, the tamarack swamps about Kewanna, Fulton County, came into view and my journey'by rail was at an end.

The tamarack or black lareh, Larix americana Michx., is a tree, fifty to one hundred feet high, with a straight trunk and slender horizontal branches. It belongs to the great Pine family or Coniferce, so called because the seeds of its members are borne without The
Tamarack Tree. scales which overlap one another to other eovering than the large flat form that familiar olject called a cone. The large majority of the members of the family, as the pines, cedars, etc., are evergreens; but the leaves of the tamarack, which are thread-like, one 
or two inches in length, and arranged along the branches in small bunches, wither and fall each autumn. The cones of the tamarack are about onehalf inch long, oroid or egg-shaped, and purple or brownish when they ripen. The wood is hard, strong, and very durable, and is used for ship building, fence posts, telegraph poles and railway ties. The slender roots are composed of tough fibres of great length. The Canadians and Indians were aceustomed to use these fibres for sewing their bark canoes, hence Hiawatha is said to have made the following request:

"Give me of your roots, O Tamarack!

Of your fibrous roots, O Larch-Tree!

My canoe to bind together,

So to bind the ends together,

That the water may not enter,

That the river may not wet me."

The tamarack is a lover of cooler climes than is furnished by our latitude, and hence flourishes in greatest abundance in the far north, its southern range in this State being on a line drawn east and west through Ft. Wayne and Kewanna. Like its cousin, the bald eypress, its chosen home is low, swampy land where it often thickly covers large areas and furnishes that dense shade so characteristic of any member of the pine family where growing closely together in great numbers.

After entering a few yards within the swamp a sense of solitude and loneliness, such as I have never felt, even in the most dense of our ordinary forests, began to oppress me-a sense which increased with every onward step and did not wholly disappear until 
I had come forth again into the full light of the sun and had left far behind me the swamp with all its eharacteristic surroundings. Much of this feeling was doubtless due to a lack of those animal sounds usually present in a forest. This lack may not be so noticeable at other seasons of the year, but on this September day it was especially striking. I listened in vain for the chirp of bird or the hum of insect. The silence was broken only at long intervals by the trill of a striped tree frog, or the low songhing of the wind in a weird and mournful cadence through the thick branches of the trees about me. The lower limbs of the tamaracks, which hung downwards as if weeping, were, for the most part, lifeless and covered with gray lichens. Many of these lichens grow in long and slender tufts like the "Spanish moss" of the Southern States; this sombre drapery but adding a deeper tinge of desolation to the scene.

But, however lonely such a swamp may appear to one who traverses it, to the botanist it is ever a place of interest on account of the many rare plants which lurk within its bounds. No grass or sedge can exist in the profound shade of the trees, but three or four kinds of sphagnum mosses grow everywhere in deep, dense masses which gave way like windrows of new mown hay beneath my tread. When dry these beds of moss furnish delightful cushions, on which when tired, one can throw himself down and rest at ease. I dug deep into one of them but could find nothing but layers of moss, the older stems slowly decaying, the younger finding a foothold and sustenance among the ruins of the old. 
Scattered through and over these mossy beds were many trailing stems of a slender shrub, bearing oblong, evergreen leaves about one-third of an inch in length. Very handsome these shrubs were, and interesting too, for on them grows that delieious and

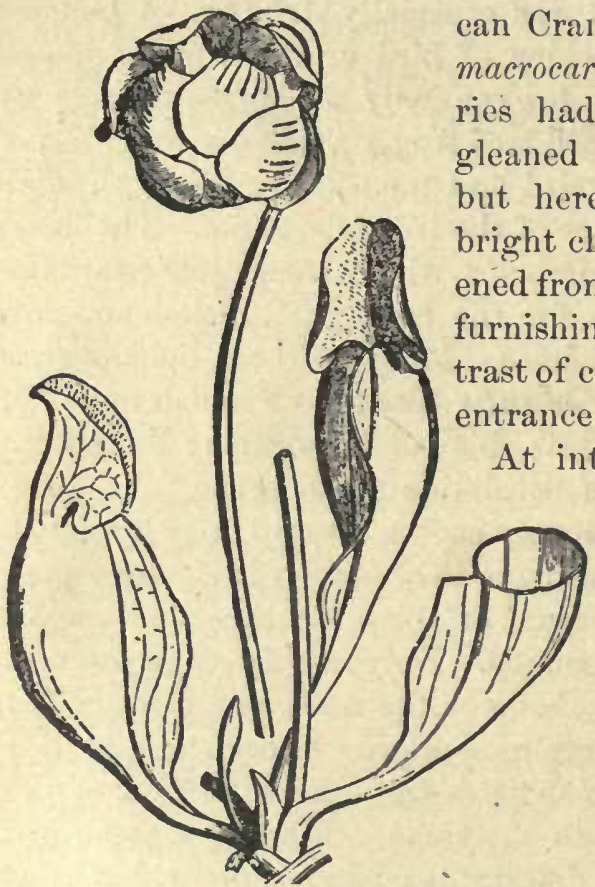

Fig. 35-Common Pitcher Plant. (After Bessey.) purpurea L. The (One leaf cut across to show the cavity. One-third $\mathrm{marg}$ in of its natural size.)

familiar fruit, the American Cranberry, Vaccinium macrocarpon Ait. The berries had been carefully. gleaned from the swamp, but here and there the bright cheek of one glistened from its bed of green, furnishing a natural concolor which would At intervals of a few feet among the thickest of the tamaracks were clumps of that curious earnivorous growth, the side-saddle flower or pitcherplant, Sarracenia thick root leaves are united in such a way as to form hollow tubes or "pitchers" with a rounded lid or lip at the top. On the inner surface of this lip are numerous stitf 
hairs pointing downwards. A watery fluid is secreted by the leaves, and collecting in the pitchers, attracts many insects. These are soon drowned, being unable to escape from the fatal pitchers on account of the deflexed hairs, and their bodies, decomposing, yield a plentiful supply of nitrogen for the crafty plant.

In May and June the strikingly handsome flower of the pitcher plant, deep purple in color and two inches or more in diameter, may be seen by the visitor to these swamps. It is borne on the summit of a leafless flower stalk or scape which springs from the midst of the elump of pitcher-shaped leaves.

In one part of the swamp grew in abundance wild huckleberries, own cousin to the cranberries, and in their season, in high favor for pies and cobblers; yet for a sauce, a failure, on account of a lack of sufficient juice and acidity. Orchids, too, were there, noted for their curiously formed flowers, which, like those of the milk-weed, can only be fertilized by the aid of insects. Though past their blooming season, three or four species were noted, among them the yellow lady's slipper, once common throughout the State but now almost extinct on account of the ruthless, devastating hand of man.

Two slender shrubs, each four to six feet high, grew in such open places as oceurred. One, the choke-berry, Pyrus arbutifolia L., is a close relation to the apple, but bears its fruit in clusters like those of the black haw of our woods. The fruit is in shaje like a miniature apple, dark red or blackish in hue, and edible, but with a puckering taste like that of a green per- 
simmon. The other is the dwarf birch, Betula pumila I., a northern plant which, like the tamarack, reaches in this swamp its southern limit in our State.

One other plant which I fain would omit from the list of those noted must now be mentioned. All those preeeding are either useful or harmless in their ways, but this one is the most poisonous species known to the flora of Indiana. It is the poison sumach or swamp elder, own brother to our common ivy but much more

\section{The Poison} Sumach. venomous as its scientific name, Rhus venenata DC., denotes. It is a shrub growing to the height of twelve or more feet. Its large compound leaves are often two feet in length and composed of nine to thirteen slender leaflets; while from their axils the white, grape-like fruit hangs in loose bunches. It grows only in the northern swamps and its juice, or even the exhalation from its leaves, causes small white blisters to appear anywhere on the surface of the exposed skin. In this swamp it was abundant, growing in every open space, and although I tried to avoid it as much as possible yet the blistered, itching skin which I endured for days after my return proved to me too well its poisoning powers.

The scarcity of, animal life within the swamp has already been mentioned. It is said to be a famous place for owls, and is in every way well fitted for those ominous birds of prey which delight in all that is dark and dismal. In the words of Thoreau : "Their 'hoo-hoo-hoo, hooer-hoo', is a sound admirably suited to swamps and twilight woods which no day illustrates, suggesting a vast undeveloped nature which 
men have not recognized. They represent the stark twilight and unsatisfied thonghts which all have." I saw no owls, but the harsh caws of a distant flock of crows which at times were wafted to my ear told. where one was treed and pestered; for the crow hates an owl as badly as a terrier hates that other "bird of night," the prowling eat.

The mottled grasshopper, Melanoplus punctulatis (Uhler), frequents the depths of the swamp in small numbers, resting either upon the trunks of the tamarack trees or the clumps of sphagnum mosses at their base. It is not active in its movements, usually, after one or two short leaps, squatting elose to the earth and, seemingly, depending upon the close similarity of its hues to the grayish lichens about it to avoid detection.

In one of the drier parts of the swamp a prairie rattle-snake gave its shrill warning almost beneath my feet, and mosquitoes of the large striped variety, regular "gallinippers," as the boys call them, occasionally had a tendency to taste my flesh; but these were only minor drawbacks which every wooer of nature must at times endure, if he would see her odd corners as well as her more commonplace ones.

$$
\text { * } *
$$

I wrote the gist of the above while sitting deeply in a bed of sphagnum moss, so deep indeed that I could scarcely move my arm while writing. And $O$, how tired I was! For 140 miles of railway travel and a five hours' tramp over bog and tussock will tire the average human. 
How I longed to lean backwards and sleep! But the rays of the sun, slanting and struggling beneath the lower branches of the tamaracks, warned me that my train would soon be due, and that if I wished to sleep at home, safe, except in dreams, from the attack of rattle-snake and mosquito, I must be up and away for the mile's trudge to the station. And so my day in a tamarack swamp became to me a thing of the past. 


\section{MID-AUTUMN ALONG THE OLD CANAL.}

Old Mother Earth once more had made the circuit of the sun and October, the fairest month of all the year, had come again and brought with it one of its perfect days. . The chilling winds and hoar frosts of the week before had warned the Rerl Man in the far west of the approach of winter and, for the first time this season, he had kindled his signal fires, and from them the smoke,

\section{"Soft and illusive as a fairy's dream, \\ Lapped all the landscape in a silvery fold."}

On such a day the gypsy in my blood-that desire to roan and wander which I inherit from the barbarians of old-asserts full strong its presence. The eity with its crowds and turmoil, its noisome smells and impure atmosphere, becomes for a time unbearable. Only a tranp through field and forest and a communion with some of the many spirits of the woods will serve to curb this gypsy element and give me peace of mind once more. And so on this, the sixteenth day of the month, and hence the very middle of the autumn, I started northward, I knew not whither; I cared not whither; but the old canal proved a cynosure and the spirits with which I communed are in part noted below.

Birds, birds, always to be seen as soon as the city limits are reached, always interesting always full of 
life and sprightliness. A bluebird first. Then a flock of juncoes or snowbirds, fresh from their summer home in the far north, perhaps tarrying for food before they go farther south, perhaps come to stay with us, to cheer us up with their chirp and twitter when King Boreas with his attendant train of ice and snow, of bare trees and almost voiceless nature, will rule over us. Then the familiar song sparrow dodging from fence erack to brush pile and back again, his streaked breast ever a sign of his identity. Then a company of grass finches showing the pure white of their tail feather's only as they fly; preparing for their southward journey by thus flocking together from their various nesting places. Then a sound-" $h a-h a-$ ha-ha"-and a trio of crows, uttering their weird laugh, went sailing southward, seeking, no doubt, their morning meal on the conmons near the city. Next, a bevy of meadow larks were flushed, and flying across the road they glided, as it were, down an inclined plane until they reached the ground, much as a flying-squirrel travels from tree top to the earth below.

By this time I had reached the canal and within the confines of its banks, where the killing effects of the recent frosts were not so visible, birds were plentiful. A pair of white-bellied nuthatches ran industriously to and fro on the branches of an elm beneath which I rested. They peered into every cranny and looked beneath every piece of loose bark in their careful search for the luckless insects which were destined to serve them for dinner. At short intervals they talked to one another in two brief words, " $k a h-$ kah;" when frightened, repeating them very rapidly, 
"kah-kah-kah-kah." At times, also, a kind of low chuckle or "pit" like sound was heard as though the bird had suddenly thought of something pleasing and was laughing to itself.

The "pe-a-body, pe-a-body, a-body, a-body," long drawn out, of the white throated sparrow, mingled with the much louder and harsher "che-wink" of the

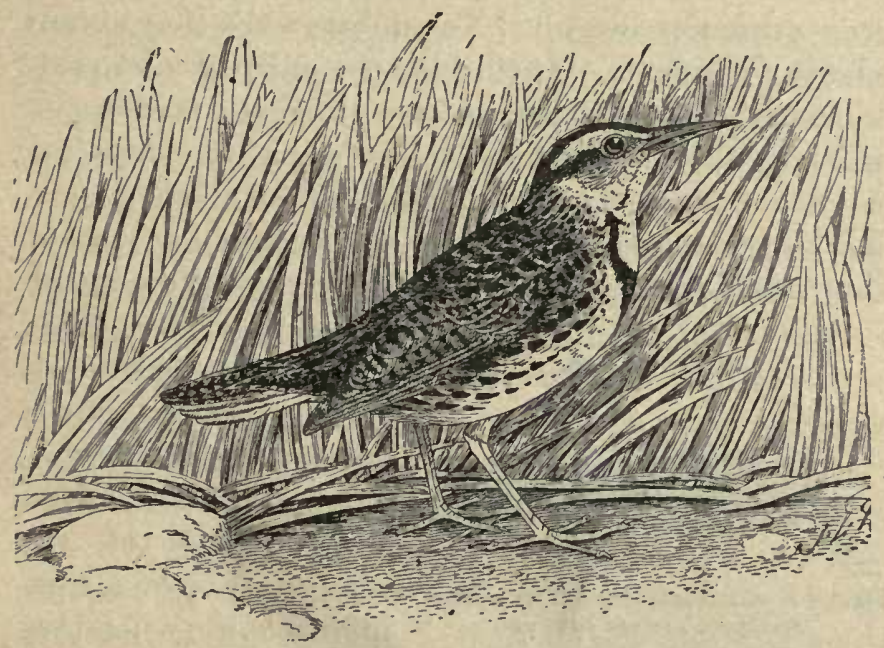

Fig. 39-Meadow Lark. (After Beal.)

marsh robin or tow-hee came from the many brush piles along the sides of the canal; while the rapid "rat-tat-tap" of a downy woodpecker upon a dead snag furnished the bass for this medley of bird sounds.

Do the members of the different families of lirds understand and converse with one another? It would seem so, for whenever a cry of distress eomes from a wounded or frightened bird, species of widely different 
families flock about and, with varied notes of alarm, evince an interest in and a sympathy for the woes of their unfortunate companion of the woods.

From mid-August to October

The ceaseless hum of insect life goes ever on, No pause for night or morn or noon-day sun.

After the first frosts, however, these insect sounds grow gradually less until November, when they almost wholly disappear. On this day the chirp of a wayside cricket, the crackling note of a clouded grasshopper, made by the male while on the wing, the drawling call of a harvest-fly which had long out-lived its day, and the feeble shrill of two or three small species of katydids were the only insect notes which were heard.

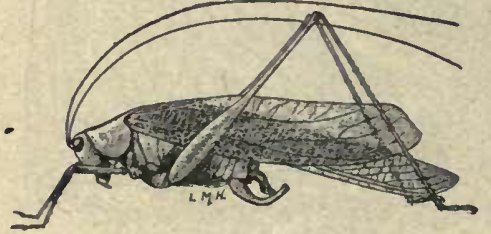

Fig.40-A small Katydid. (After Lugger.) Scudderia furcata Brunner.

Even they were only occasional weak wails -woe begotten sounds of frost-bitten individuals-and not the loud shrill notes of the same species of a fortnight before, when love demanded tribute in the form of ceaseless song and all went merry as a marriage bell.

Where a barbed-wire fence stretched across the bed of the eanal a novel sight came into view. Hundreds, yes thousands, of strands of spider Spiders As Balloonists. webs were floating from the sides of the posts and wires. The wind was from the south and they were blown northward, the free ends floating horizontally and parallel in the air. 
A close examination revealed the presence of a great many spiders of minute size on the surface of the posts and wires. Their abdomens were slightly raised and from the spimmerets of each were issuing threads of web material which soon hardened when exposed to air. These, in time, formed a strand sufficiently long to support the weight of the little spimners: Then, if the strand did not become entangled with some others, the spiderkin, letting go its hold upon the fence, took a ride to the northward with the wind as a motor. Wonderful balloonists they-whose ancestors performed like feats of aërial navigation ages before the days of the first human aëronant!

Numerous wild fruits and nuts, both edible and unedible, are in autumn found along, the banks of the canal. The former satisfy the sense of taste and are usually dull in color but interesting in structure and habit. Among them are two speeies of wild grapes, one, the frost or ehicken grape, Vitis cordifolia Michx., with small black and shining berries which are very sour; the other, the summer or fox grape, $V$. astiralis Michx., having the berries larger, with a sweet and pleasant flavor and with their black skins covered with a whitish bloom. The chief charm of the wild grape lies, however, in the spreading, straggling habits of the vine which covers many thorn and other homely bushes, and forms in the angles of the old Virginia rail fences those dense, leafy coverts which in summer delight the brown thrush and make glad the heart of the handsome chewink.

The hazelnut, Corylus americana. Walt., also flourishes in this sandy soil and on this day many clumps 
of them were noted. Their oval leaves painted a dainty brown by the frost, were withering and dropping, thus disclosing more plainly the bunches of brown nuts each clad in its protective armor of involucre. An interesting fact about the hazelnut is that its eatkins, earnest of next season's flowers, are formed in late summer and pass the winter in patient waiting, ready to take advantage of the first warm days of spring to open their cups of pollen and fertilize the flowers for the finture crop of nuts.

Our unedible wild fruits usually cater to the sense of sight, being bright in color or peculiar in structure. Among them all, that of the wahoo or burning bush seems to me most beautiful. Hanging on slender pedicels, four or more in a cluster from the same peduncle, its deep scarlet color and odd shape render it a most striking olject. Add to this the orange aril of its seeds, peeping so daintily through the half open suture of the pod after the latter has been touched by one or two keen frosts, and we have a combination and a contrast most pleasing to the eye.

Of the fifty or more species of birds which pass the cold season in Indiana, the little winter wren, in his russet coat, is the smallest.and, in

The Winter Wren. habits, one of the most peculiar. Wherever you see him, be it on the ground, in a fence corner, or in a pile of brush or rails, he is continually on the go, flitting hither and thither, in and out of the cracks of the fence and from top to bottom of the brush pile; so that if you are a collector and want his skin you have to take him on the wing or not at all. It was, therefore, with a feeling of 
delight that I heard, as I strolled along on this bright October day, his merry "che-che-che-che-che," and saw him as he ran up and down the side of a stump in search of insects. He saw me also and seemed to know that it was Sunday, and, therefore, he need have no fear; for, instead of flitting away as is his usual custom, he came nearer and nearer, seeking, as it were, to gain my friendship, until at last I could have touched him with my hand and even did reach it forth, thinking that, like Thoreau's sparrow, he might light thereon. But some spirit must have whispered to him of his three dead kinsmen whose skins form part of my collection; for no sooner did I stretch forth my hand than he was up and away like a flash. Ah, my little feathered friend, thou needst not thus so suddenly have left $\mathrm{my}$ presence, for I had no thoughts of murder in my heart, but simply wished to bid thee weleome to thy winter's home!

I rested for a time beneath a tall white oak and watched the falling leaves as, obedient to the great force of gravitation, they drifted slowly towards the center of the earth. Who can tell when a leaf breaks its hold upon the parent tree where its resting place will be? It comes fluttering down on account of the A Falling Leaf. broad expanse which its light weight presents to the resistance of the atmosphere. It is borne, now in this direction, now in that, by the eddying gusts until at last it rests. "pon a pile of a hundred others, perhaps fifty, perhaps five hundred feet from a perpendicular from where it started. By the action of water and oxygen, it and its companions are soon changed into inorganic 
substances and become a part of the earth's mold. Possibly they have been a part of it hundreds, aye, thousands of times before; for who knows what varied forms the carbon, hydrogen and oxygen, now locked up in the cells of the leaf, have in the past helped to produce? Of what plant, what animal, what man have they formed a part? But however varied the object, which in by-gone ages they have helped to form, it has in tima fallen again to the earth, been disintegrated, and again, by the action of the energy of sunlight, the elements composing it have been rebuilt into a new organic body which has aided the onward march of our common mother and fitted her better for the abode of man.

Thus we see in a falling leaf, as it were, a similitude of our own lives, as we, tearing ourselves loose from parents and home after having been nourished to the ripeness of manhood, are borne hither and thither by the blasts and eddyings of fate and of the great society in which we mingle, until at last we, too, find a resting place in the earth and yield back to her the elements which are her own.

While musing thus over the falling leaf, the Indian summer day, perfect as it was, eame to a close. It was, let us hope, the first of many yet to be this antumn. For on such days we enjoy the smile of nature -tender and beatiful-her last before she dons her seeming shroud for winter wear.

"So we shall find-our summer being past, And hoar frost witl us-for a little breath So fair a country, such a genial air, And sluall forget our woes, and unaware Slep orer the borderland of death." 


\section{KATYDIDS AND THEIR KIN, OR THE ORTHOPTERA OF INDIANA.}

The word "Orthoptera" means "straight-winged." It is a name given to an order or group of insects, which comprises the katydids, grasshoppers, erickets, cockroaches, walking-sticks, etc. The members of the order may be known by their biting mouth parts, and their indireet metamorphosis; the young when hatched being wingless, but of the same form as the parent; the wings developing gradually and appearing of full size after the skin lias been shed for the fifth time, when they are membranous and, in the typical forms, laid straight along the back. In number of species the order Orthoptera is a small one, but about 850 having been described from the United States. Of these I have taken, personally, $127 \mathrm{in}$ Indiana, divided among six families, as follows: Blattide or cockroaches, nine; Phasmide or walkingsticks, one; Mantide or rear-horses, two; Locustidce or katydids and green grasshoppers, 39; Gryllide or crickets, 25; Acrididee or short-horned grasshoppers, 51. Taking up briefly, each of these families, let us note the chalacters which distinguish its members, and give a few facts concerning the labits and life histories of the more common and familiar examples of each which are found in Indiana. 


\section{BLATTIDA.}

From the other families of Orthoptera the Blattide, commonly known as cockroaches, may be known by their depressed oval form; their nearly horizontal head, which is bent downward and almost concealed by the broad chest or pro-thorax ; their slender legs of equal length and size; their five-jointed tarsi or feet, and by the absence of either ovipositor or foreeps-like appendages at the end of the abdomen.

The rings of the abdomen overlap each other and are capable of great extension and depression, so that these insects seem to be pre-eminently fitted for living in the narrow crevices and cracks which they inhabit. The legs are of peculiar structure, in that they are long and more or less flattened, thus enabling the eockroaches to run with surprising swiftness; so that the family has been placed by some writers in a separate sub-order, the Cursoria or runners. The wing covers or outer wings are leathery, translucent, and, when developed, overlap when at rest; while the wings never exceed the wing covers in length, and in some cases are rudimentary or even wanting.

From the other Orthoptera the cockroaches differ widely in their halits of oviposition, as the eggs are not laid one at a time, but all at once, in a peculiar capsule or egg-case, called an oötheca.* 'These capsules vary in the different species, as regards the size, shape, and number of eggs they entain, but they are all similar in structure. Each one is divided lengthwise by a membranous partition into two cells. Within

\footnotetext{
${ }^{*}$ See Fig. 44 for illustration of oötheea of Croton bug.
} 
each of these cells is a single row of cylindrical ponches, somewhat similar in appearance to those of a cartridge belt, and within each pouch is an egg. The female cockroach often runs about for several days with an egg case protruding from the abdomen, but finally drops it in a suitable place, and from it the young in time emerge. While this method of oviposition is the one practiced by all the species of common occurrence in the United States, there seem to be exceptions to it, as Dr. C. V. Riley a few years ago recorded the fact of an introduced tropical cockroach which produced the young alive.

All young cockroaches resemble the parents in form, but are wholly wingless, the wings not appearing until after the fiftl or last noult.' The young are often mistaken for mature individuals by persons who have not made a careful study of the life history of the insects; and those of one or two well known and common forms have, in the past, even been described or figured as distinct, wingless species by some of the leading entomologists of the country.

Although abundantly represented in individuals, the number of species of eockroaches inhabiting the Eastern United States is comparatively few, but about twenty having been recorded. Of these, nine, representing five different genera, are known to occur in Indiana. Of the nine, seven are indigenons or native species, the other two having been introduced from the Old World.

In this connection I shall consider the habits of four of these insects, the first of which is the Oriental or black roach, Periplaneta orientalis (L.). This species is 
dark mahogany-brown in color, and full grown specimens are about an inch in length. The outer wings of the female are only about one-fifth of an inch long, while those of the male are more than half an inch and

The Oriental , eover three-fourths or more of the or

Black Roach. a native of Asia, but has been carried from one country to another by shipping. It delights in filth and darkness, and hence in the holds of vessels, the cellars and basements of tene-

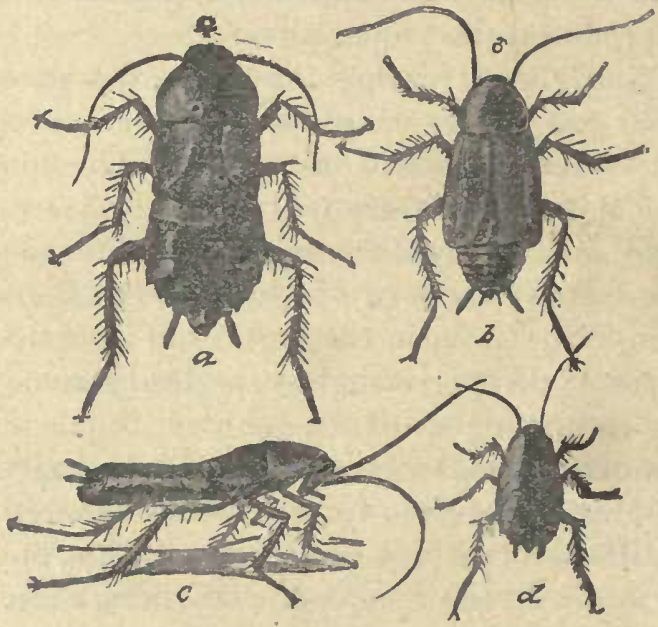

Fig. 41-Oriental or Black Roach.

( $a$, female; $b$, male; $c$, sicle view of female; $d$, half-grown specimen. After lloward.)

ment houses, and in all damp, dirty places it swarms by thonsands, undoubtedly doing much good as a scavenger, but infinitely more harm on accomit of its omnivorous and insatiable appetite. Like most other 
members of the family, it feeds mainly at night, appearing to detest and avoid the light, as one can readily prove by taking a lighted lamp suddenly into its haunts, when a hurried scrambling will take place towards its daylight retreats, and but a few moments will elapse before the last of the busy marauders will have disappeared.

This is probably the most carnivorous of all our cockroaches, though, like most others, it is fond of starchy food. It is known to feed upon meat, cheese, woolen clothes, and even old leather, and is said to be especially fond of the festive bed-bug, Acanthia lectularia L., which soon disappears from a house infested with the Oriental roach.

Its eggs are sixteen in number, and the large horny capsule or oötheca in which they are packed is carried about by the mother for a week or longer when she drops it in a warm and sheltered place. Along one side of the eapsule, which resembles in form and color a diminutive seed of the papaw, Asimina triloba Dunal, is a scam where the two edges are cemented closely together. When the young are hatched they excrete a liquid which dissolves the cement and enables them to escape without assistance, leaving their infantile receptacle as entire as it was before they quitted it.

In Indiana the Oriental roach is found in all the larger towns and cities, and is one of the most noisome and disagreeable insects with which certain classes of their inhabitants have to contend. It seldom oecurs in houses in thinly settled localities, and never, as far as my observation goes, beneath the bark of logs and stumps. 
The American cockroach, Periplaneta americana

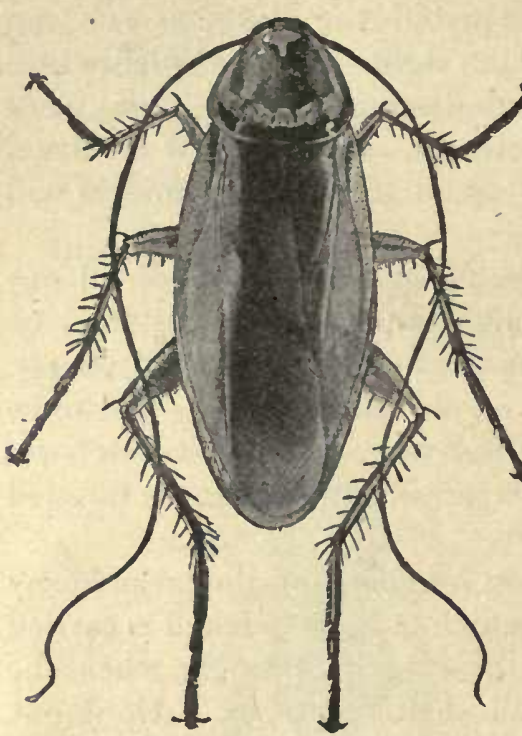

Fig. 42-American Cockroach.

(Eniarged one-third. After Howard.)

(I.), is, as its name implies, a native of th is country, but, like the Oriental roach, it has spread to the four cormers of the earth. It is by far the largest species found in the State, the male measuring $1 \frac{4}{5}$ inches from head to tip of wings, the latter in both sexes reaching beyoud the end of the abdomen. The general color is reddish-brown, the top of the thorax being margined rather broadly with yellow. In Indiana it seems to be of rather limited dis-

The

American

Cockroach. tribution, as I know of its oecurrence in but two counties, Putnam and Marion. It occurs in numbers in some of the leading hotels of Indianapolis, but usually confines itself to the basement and first floor, aud appears to be much more cleanly in its choice of an abiding place than does the closely allied Oriental roach.

The Pennsylvania coekroach, Ischnoptera pennsylvanica (DeGeer), is also a native species, and is the 
most common roach in the State, being found everywhere beneath the loose bark of logs and old stumps. It is usually seen in the wingless The stages, the mature individuals being Pennsylvania Cockroach. common only from May to October. The half grown young are of a shining, dark brown eolor, the dorsal surface of the thoracic segments often lighter. The wings of adult specimens are long and narrow, extending in both sexes much beyond the tip of the abdomen. The total length is more than an inch and the color is reddish-brown with a whitish stripe on the margins of wings and thorax.

As mature specimens are attracted by light, country houses are often badly infested with them; and where food is scarce the wall paper is sometimes much injured for the sake of

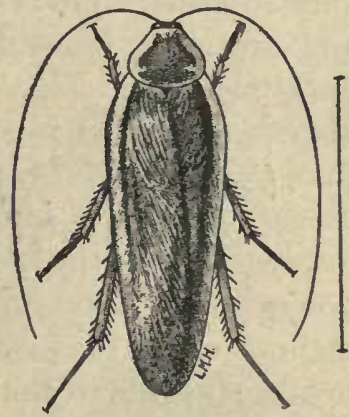

Fig. 43-Pennsylvania Cockroach. (After Lugger.) the paste beneath. What the hordes of young which dwell under the bark of logs live upon is a question as yet unsettled, but the larva of other insects undoubtedly form a portion of their food, as in two instances I have found them feeding upon the dead grubs of a Tenebrio beetle; while living, as well as decaying, vegetable matter probably forms the other portion. The mating of the adults mostly occurs in late summer and early autumn, the newly hatched young being most abundant from midSeptember until December. The young in various 
stages of growth survive the winter in the places mentioned, they being the most common insects noted in the woods at that season. Cold has seeningly but little effect on them, as they scramble away almost as hurriedly when their protective shelter of bark is removed on a day in mid-January with the mercury at zero, as they do in June, when it registers a hundred in the shade.

The empty egg cases of the Pennsylvania roach are very common objects beneath the loose bark of logs and especially beneath the long flakes of the shellbark lickory. They are chestnut brown in color, about $\frac{1}{3} \times \frac{1}{6}$ inches in size, and are much less flattened than those of the Croton bug, described below. The dorsal or entire edge is slightly curved or bent inwards, after the fashion of a small bean. The young, after hatching, evidently escape in the same manner as do those of the Oriental cockroach, as no break is visible in the empty capsule.

The last of the four cockroaches to be considered is the "Croton bug," Phyllodromia germanica (L.), so called because it made its appearance in New York City in numbers about the time the Croton aqueduet was completed. It is a native of Central Europe, but like the Oriental roach has beeome cosmopolitan.

This is one of the smallest of the nine cockroaches known to oceur in the State; the total length being $\frac{1}{2}$ inch or less. The general color is a

The Croton Bug. light brownish-yellow, the females often darker. The thorax has two dark brown bands, enclosing a yellowish stripe. The egg case of the Croton bug is very light brown, 
a little over twice as long as broad, with the sides somewhat flattened and the edges parallel. Within it the eggs, thirtyrsix in number, are arranged in the usual two rows. It is carried about by the mother roach for several days with from half to three-fourths of its length protruding from the abdomen, and when dropped in a favorable place the young evidently very soon emerge from it; for in a bottle in which a female with protruding oötheca was placed at eleven o'clock P. M. the young were found to have emerged on the following morning at eight.

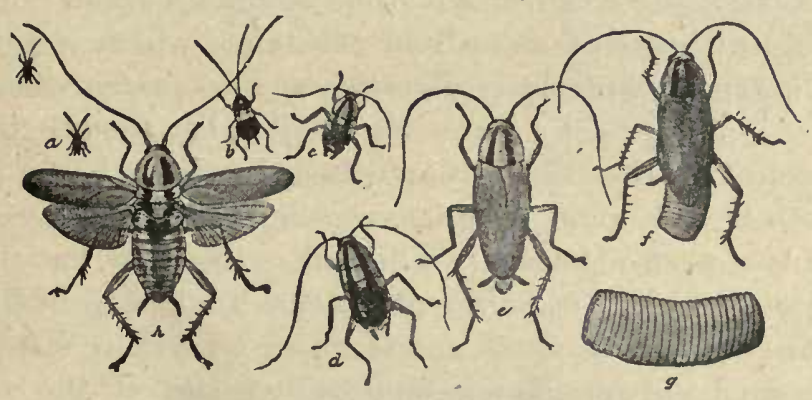

Fig. 44-Croton Bug.

( $a$, first stage; $b$, second stage; $c$, third stage; $d$, fourth stage; $e$, adult; $f$, adult female with egg case; $g$, egg cuse enlarged; $h$, adult with wings spread. After Howard.)

The Croton bug seldom, if ever, occurs in numbers in the country, lut is one of the worst insect pests with which the inhabitants of the larger eities of Indiana have to deal. It is the most fecund of all the roaches, and the seasons of mating and hatching of the young are, perhaps, more irregular than in any other species. Adult forms are evirlently to be found at all seasons of the year, as I have taken them in 
December, April and October. It is not so much a lover of filthy surroundings as is the Oriental roach, and hence frequents much more often than that species the dwellings of the better class of people. It delights in warm, moist places, and is especially abundant and destructive in buildings which are heated by steam. Where it once obtains a foothold and the surroundings of temperature and food supply are favorable, it is almost impossible to eradicate, as its small, flattened form enables it to hide and breed in cracks and crevices, which none of the larger roaches can enter.

Like many other omnivorous animals, Croton bugs find in wheaten flour a food substance which is rich in nutrition and easily digested, and so prefer wheat breads and starehy materials to all other foods. On account of this liking they often do much harm to cloth-bound books by gnawing their covers in search of the paste beneath. They also seem to have a peeuliar liking for paints of various kinds, and in the office of the U. S. Coast and Geodetic Survey at Washington, have done much damage by eating off the red and blue paints from the drawings of important maps. On one oceasion they made a raid on a box of water colors, where they devonred the cakes of paint, vermilion, cobalt and umber, alike; and the only vestiges left were the excrements in the form of small pellets of various colors in the bottom of the box.

In giving a remedy for this and other species of cockroaches which frequent houses, I can not do better than quote from Dr. Riley's excellent article in "Insect Life." He says: "Without condemning other useful measures or remedies like borax, I would 
repeat that in the free and persistent use of California Buhach, or some other fresh and reliable brand of Pyrethrum or Persian Insect Powder, we have the most satisfactory means of dealing with these roaches.

"Just before nightfall go into the infested rooms and puff into all crevices, under base-boards, into drawers and cracks of old furniture-in fact, wherever there is a crack-and in the morning the floor will be covered with dead and dying or demoralized and paralyzed roaches, which may easily be swept up or otherwise collected and burned.

"With cleanliness and persistency in these methors the pest may be substantially driven out of a honse, and should never be allowed to get full possession by immigrants from without.

"For no other insects have so many quack remedies been urged and are so many newspaper remedies published. Many of them have their good points, but the majority are worthless. In fact, rather than put faith in half of those which have been published, it would be better to rely on the recipe which is current among the Mexicans:

"'To Get Rid of Cockroaches.-Catch three and put them in a bottle, and so carry them to where two roads eross. Here hold the bottle upside down, and as they fall out repeat aloud three credos. Then all the cockroaches in the house from which these three came will go away." 


\section{PHASMIDA.}

Belonging to the family Phasmida, there occurs in Indiana, as far as known, but one species, the walkingstick, Diapheromera femorata (Say). This insect furnishes

$\begin{array}{cl}\text { The Walking- } & \text { a most ex- } \\ \text { stick. cellent ex- } & \text { ample of }\end{array}$ adaptation for the purpose of protection. It is wingless and possesses a long, eylindrical body, resembling a slender stick with the bark on it. It moves very slowly, and has a habit of remaining motionless and apparently dead for a consirlerible length of time. On such occasions it usually stretches itself out from a twig, with its front legs and antennie extended, and then can searcely be distinguished from a prolongation or lranch of the twig. Many people who see them thus for the first time and afterwards watch them moving slowly away, can scarcely be persuaded that they are not real twigs, gifted in sone

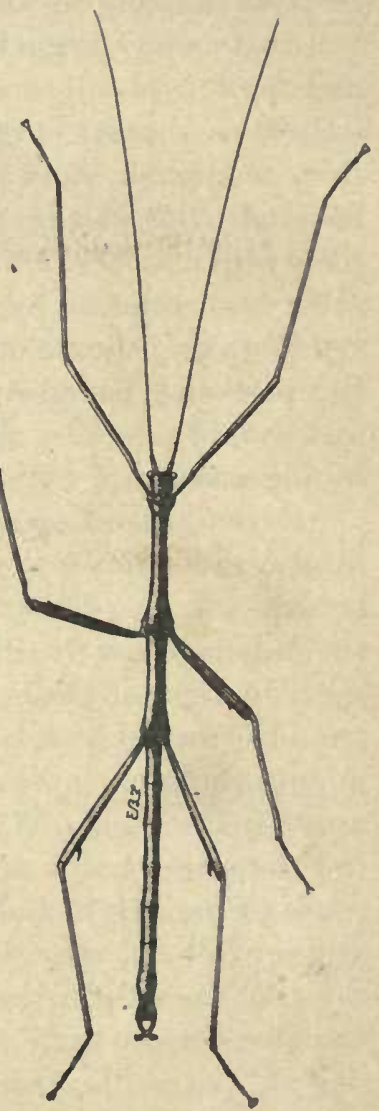

Fig. 45-Walking-stick.

(After Lugger.) mysterious manner with life and motion. 
The walking-stick feeds, during its entire life, upon the foliage of various trees, being especially fond of the leaves of the wild cherry. The eggs are dropped upon the ground by the mother insect, who takes no farther notice of them. The young, when hatched, trust to chance and their peculiar shape to escape those higher forms which are ever ready to prey upon every living thing which promises them a bit of sustenance.

\section{MANTID A.}

Two species of the family Mantidae are found sparingly in southern Indiana. Of these the best known is the Carolina mantis, or rear-horse, one of the two

The Carolina Mantis.

or three species of Orthoptera, which are in the slightest degree beneficial. It is a rather large insect, of a greenish or gray color. When disturbed it elevates or rears the fore part of its body almost perpendicularly, fixes its large, staring eyes upon the intruder and turns its head sideways in a very ludicrous manner, so as to follow, if possible, every movement of its supposed enemy. If a small object, as a blade of grass, be then thrust towards it, it will strike out vigorously with its saber-like fore feet, or else retreat to what it considers a safe distance.

Being a rapacions insect, its fore limbs have, in time, become peculiarly adapted for grasping organs. The tibix are robust and armed with a double row of spines; the tarsi or feet are short, spiny and curved so as to fit into the under side of the tibire like the blade of a clasp knife when closed. When in pursuit 
of its prey the mantis moves almost imperceptibly along, stealing towards its victim like a cat approaching a mouse. When sufficiently near, the fore leg is suddenly extended to its full length and the unlueky insect is immediately caught and impaled by the spines between the tibixe and tarsi, carried to the mouth and deliberately eaten piecemeal while yet alive and struggling to escape.

The Carolina mantis is occasionally found as far north as Indianapolis, where it reaches maturity about September 1st. When the two sexes are cap-

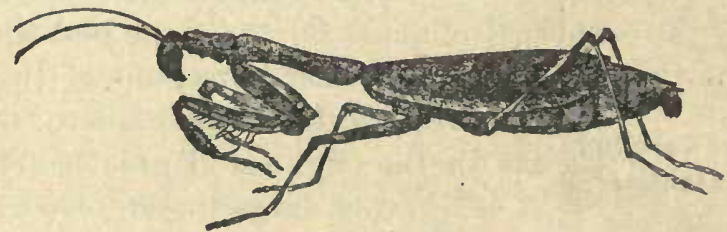

Fig. 46-Carolina Mantis.

tured and placed together the female soon begins to feed upon her liege lord, and finally devours all portions of him which are in the least degree digestible. The eggs are gromped together in agglutinated masses of 40 or more and covered with a coarse web of silk, the top of the mass then appearing as if its component parts were braided together. In this manner the species survives the winter and in May, when insect life begins to abound, the young emerge and use their prominent staring eyes to good advantage in seeking plant lice and other minute forms which furnish them their first of many meals. 
LOCUSTIDA.

The family of Orthoptera known as the Locustida comprises those insects commonly called katydids, green grasshoppers, and stone or camel crickets. The distinguishing characters of the members of this family are the long, slender, tapering, many-jointed antenuæ; the almost universal absence of simple eyes; the four-jointed tarsi or feet; and the swordshaped ovipositor of the females. The outer wings, when present, slope obliquely downwards, instead of being bent abruptly, as in the cricket family; and in most eases the wings are longer than the wing covers.

The stridulating or musical organ of the males is quite similar in structure to that of the male cricket, being found at the base of the overlapping dorsal surface of the wing covers and usually consisting of a transparent membrane, of a more or less rounded form, which is crossed by a prominent curved vein bearing on the under side a single row of minute filelike teeth. In stridulating, the wing covers are moved apart and then shuffled together again, when these teeth are rubbed over a vein on the upper surface of the other wing cover, producing the familiar, socalled "katydid" sound. Each of the different species makes a distinct eall or note of its own, and many of them have two calls, one which they use by night and the other by day. Any one who will pay close attention to these different calls can soon learn to distinguish each species by its note as readily as the ornithologist ean recognize different species of birds in the same manner. The ear of these insects, 
when present, is also similar in structure and position to that of the ericket's, being an oblong or oval cavity covered with a transparent or whitish membrane, and situated on the front leg near the basal end of the tibia.

The young of the Locustida, like those of the other families of the order, when hatehed from the egg resemble the adnlts in form but are wholly wingless. As they increase in size they moult or shed the skin five times, the wings each time becoming more apparent, until after the fifth moult, when they appear fully developed, and the insect is mature or full grown, never increasing in size thereafter. Throughout their entire lives they are active, greedy feeders, mostly herbivorous in habit; and, where present in numbers, necessarily do much harm to growing vegetation. Thirty-nine species of the family are known to occur in Indiana.

Popularly speaking, we may divide the members of the family into three groups, the katydids, green grasshoppers and stone or camel erickets. Taking these up in the order mentioned, we find that the "katydids," nine species of which have, up to the present, been recorded from the State, are the most arboreal of all the Locustidoe. The great majority of them pass their entire lives on shrubs and trees,

\section{The} Katydids. where they feed upon the leaves and tender twigs, and, when present in numbers, often do excessive injury. The color and form of their wings serve admirably to proteet them against their worst foes, the birds; and as they live a solitary life, $i$. e., do not flock together 
in numbers as do the green grasshoppers, they are but seldom noticed by man. Their love calls or songs, however, make the welkin ring at night from midAugust until after heavy frost, and though but one of the nine species found in the State makes a note in any way resembling the syllables "katy-did, shedid," yet all are accredited with this sound by the casual observer, and hence the common. name usually given to the members of this sub-family. Their call is seldom made by day for the obvious reason that it might attract the attention of the birds and so lead to the destruction of the insect. As twilight approaches, however, the male of each species begins his peculiar note, which is kept up, with little or no intermission, until the approach of day warns him that his feathered enemies will soon be on the alert, and that silence will be, for a time, the best policy to pursue.

From the other Locustidae the katydids differ widely in their habits of oviposition, the eggs not being deposited on the earth or in twigs, but are usually glued fast in double rows to the outer surface of slender twigs or on the edges of leaves. The eggs of the most common species appear like flattened hemp seeds, and usually overlap one another in the row in which they are placed. On account of this method of oviposition, the ovipositors

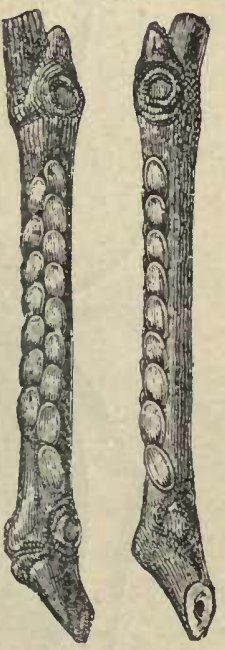

Fig. 17-Eggs of Angular-winged Katydid. of the katydids are broader, more curved and more 
obtuse at the end than in the other sub-families, whose members oviposit in the earth or in the stems of grass.

The broad-winged or "true katydid," Cyrtophyllus concavus (Harris), is found in considerable numbers throughout the State, but is much

The Broadwinged Katydid. more commonly heard than seen, as it dwells singly or in pairs in the densest foliage which it can find, such as the tops of shade trees and the entwining vines of the

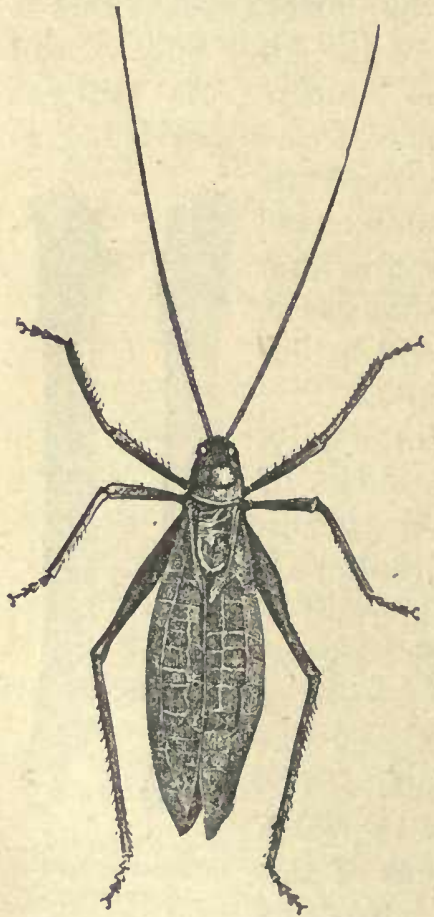

Fig. 48-Broad-winged Katydid.

(Male. After Ilarris.) grape arbor. In central Indiana it reaches maturity as early as July 20 ; and is more domestic in its habits than any other species of the "katydid" group, frequenting, for the most part, the shrubbery of yards, orchards and the trees along fence rows, being seldom heard in extensive wooded tracts. Its note is the loudest made by any member of the fanily, the male having the musical organ larger and better developed than in any other. The call is almost always begun soon after dusk with a single note uttered at intervals of about five seconds for a half dozen 
or more times. This preliminary note gives the listener the impression that the musician is tuning his instrument preparatory to the well known double call which is soon begun and kept up almost continuously from dark till dawn.

Of this call, Mr. S. H. Scudder has written: "The note of the true katydid, which sounds like $X r$, has a shocking lack of melody; the poets who have sung its praises, must have heard it at the distance that lends enchantment. In close proximity, the sound is excessively rasping and grating-louder and coarser than I have ever heard from any of the Locustarians in America or in Europe, and the Locustarians are the noisiest of all Orthoptera. Since these creatures are abundant wherever they occur, the noise produced by them, on an evening especially favorable to their song, is most discordant. Usually, the notes are two in number, rapidly repeated at short intervals. Perhaps nine out of ten will ordinarily give this number, but occasionally a stubborn insect persists in sounding the triple note- 'katy-she-did'-and as katydids appear desirous of defiantly answering their neighbors in the same measure, the proximity of a treblevoiced songster demoralizes a whole neighborhood, and a curious medley results. Notes from some individuals may then be heard all the while, scarcely a moment's time intervening between their stridulations-some nearer, others at a greater distance-so that the air is filled by these noisy troubadours with an indescribably confused and grating clatter."

The "angular-winged katydid," Microcentrum laurifolium (L.), is another species which in the country is 
commonly called "the katydid," and the note of Cyrtophyllus concavus is usually attributed to it but its true note may be represented "by the The Angular-winged syllable 'tic,' repeated from eight to Katydid. twenty times at the rate of about foul to the second." It is evidently attracted by light, being often found in the gutters

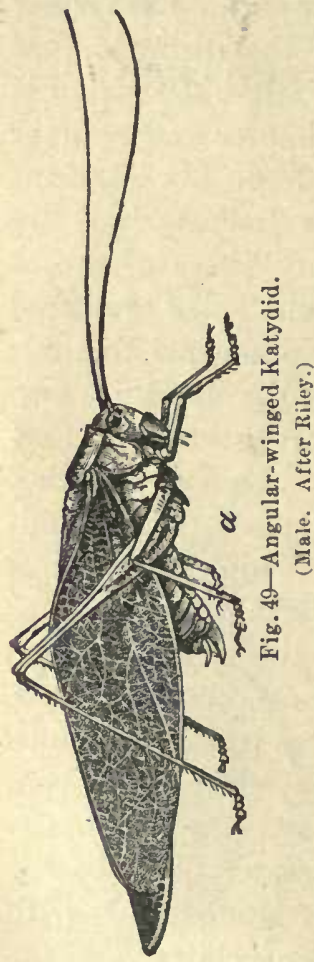
beneath the electrie lights in the larger eities and towns. It oeeurs, probably, throughout the State, but is more common southward and is nowhere found in sufficient numbers to be injurious. The eggs are laid on twigs which have been previously roughened with the jaws and otherwise prepared for a place of deposit. The two rows are contiguous and the eggs of one alternate with those of the other. Those of the same row overlap about one-fourth of their length. They are of a grayish brown color, long oval in shape, very flat, and measure $5.5 \times 3 \mathrm{~mm}$. They are usually deposited in September, hatch the following May, and the young, in central Indiana, reach maturity during the first half of August.

The green grasshoppers are those slender-bodied Locustida, with long, tapering antennæ, which are so 
common in summer and early autumn in damp meadows and prairies, and along the mar-

The Green Grasshoppers. gins of streams, ditehes and ponds. They are mostly terrestrial in their habits, but one or two of the larger ones ever being found in trees.

Of this group 21 speeies have been found in Indiana, four of which, called "cone-headed grasshoppers," are more than twice as large as the others and have the vertex or top of the head prolonged forwards and upwards into a prominent cone. The outer wings are long and slender, and the ovipositor is oftentimes of excessive length. The total length of the females is between one and a half and two inches, that of the males averaging about a third less.

These insects seem to "possess more intelligence than is usual among the Orthoptera, and they are about the most difficult of the order to approach. In eseaping they usually slip or fall into the grass instead of jumping or flying; but they seem to fully understand that they are very well protected by their color and form. If approached very eautiously they often remain quite still upon the stem of grass upon which you have surprised them, with the usually well founded expectation that you will not be able to distinguish them from the green herbage around. If they think it worth while to make some active movement to eseape they will frequently slip around on the other side of the stem and walk down it to the ground or off upon another plant. Unlike most Orthoptera they do not use their front legs in holding to the mouth the thing upon which they feed. 
Instead of biting they seem to wrench or tear away pieces from the stems or leaves."

The females of the cone-heads deposit their eggs between the stems and root leaves of coarse grasses and sedges. The young are hatched in May and reach maturity about the 5th of August. The notes of the male vary much according to species, that of the more common "sword-bearer," Conocephalus ensiger Harris, being similar to the syllables "ik-ik-ik," as if sharpening a saw, this sound enlivening low

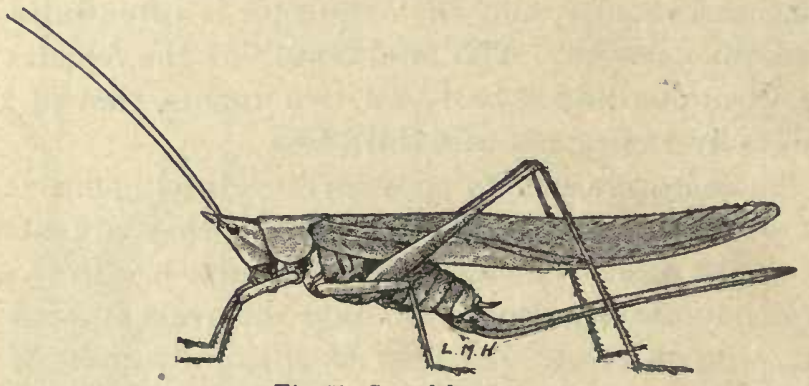

Fig. 50-Sword-bearer.

(Female. After Lugger.)

bushes, and particularly the corn patch, as it seems to especially delight in perching near the top of a cornstalk and there giving forth its rather impulsive song.

The other members of the green-grasshopper group, 17 in number known to oceur in the State, seldom exceed three-fourths of an inch in length. The color of their bodies corresponds closely to that of the stems and leaves of the sedges and grasses among which they dwell; and so protects them from the sight 
of the few birds which frequent a like locality. Their songs, produced in the same manner as those of their larger cousins, the katydids, are as frequent by day as by night, but are usually soft and low in comparison with those of the former. Their day song differs from that of the night, and, "it is curious to observe these little creatures suddenly changing from the day to the night song at the mere passing of a cloud, and returning to the old note when the sky is clear. By imitating the two songs in the daytime, the grasshopper can be made to represent either at will ; at night they have but one note."

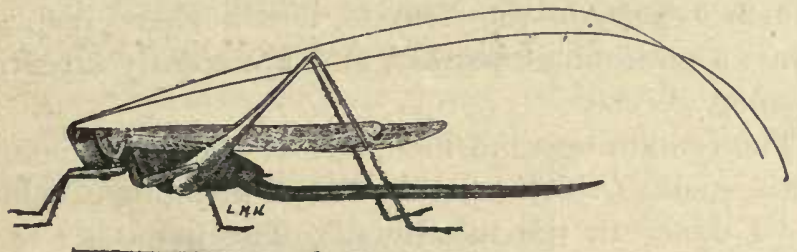

Fig. 51-Lance-tailed Grasshopper.

Xiphidium attenuatum Scudder.

The eggs of these smaller green grasshoppers are deposited within the stems or root leaves of grass, the pith of twigs, or sometimes in the turnip-shaped galls so common on certain species of willow. The ovipositor being thus used as a piercer, has in time developed into a slender and sharp-pointed instrument which is but little curved and is frequently of excessive length, in some species being over twice as long as the remainder of the body.

Eight of the seventeen belong to the genus Xiphidium, meaning "sword-bearer," which includes the 
smallest and most slender-bodied of the winged Locustidce.

A very common member of this genus in western Indiana is Xiphidium nemorale Scudder. It reaches maturity about August 15 th and from then until after heavy frosts may be found in numbers along the borders of dry, upland woods, fenee rows and roadsides, where it delights to rest on the low shrubs, blackberry bushes, or coarse weeds usually growing in such localities. On the sumny afternoons of mid-autumn it is especially abundant on the lower parts of the rail and board fences, the male uttering his faint and monotonous love call-a sort of ch-e-e-e-e-ch-e-e-e-e, continnously repeated-the female but a short distanee away, a motionless, patient, and apparently attentive listener.

The remaining nine members of the group belong to the genus Orchelimum, the literal meaning of which is, "I dance in the meadows." The name is a most appropriate one, for low, moist meadows everywhere swarm with these inseets from July to November; and though waltzes and quadrilles are probably not indulged in, yet the music and song, the wooing and love making, which are the natural aceompaniments of those amusements, are ever present, and make the short season of mature life of the partieipants a seemingly happy one.

Among these the "common meadow grasshopper," Orchelimum vulgare IIarris, is probably the most abundant member of the family Locustida found in Indiana. It begins to reach maturity in the central part of the State about July 20th, and more frequently 
than any other of our species of Orchelimum is found in upland localities, along fence rows, and in clover and timothy meadows. In early autumn it is very fond of resting on the leaves and stems of the iron-weed so common in many blue-grass pastures.

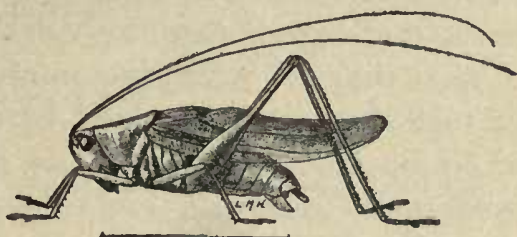

Fig. 52-Comınon Meadow Grasshopper. (Male, After Lugger.)

This green grasshopper seems to be somewhat carnivorous in habit, as on two occasions I have discovered it feeding upon the bodies of small moths which in some way it had managed to capture. The note of the male is the familiar $z i p-z i p-z i p-z i p-z e-e-e-e$ - the first part being repeated about four times, usually about twice a seeond; the $z e-e-e-e$ continuing from two or three to twenty or more seconds.

"The poetry of earth is never dead:

When all the birds are faint with the hot sun,

And hide in cooling trees, a voice will run

From hedge to hedge about the new mown mead;

That is the grasshopper's-he takes the lead

In summer luxury, he has never done

With his delights; for when tired out with fun

He rests at ease beneath some pleasant weed."

The "stone or camel crickets," nine species of which occur in Indiana, are wingless Locustidee of medium or large size with a thick

The Stone or Camel Crickets. body and arched back. They are seldom seen except by the professional collector, as they are nocturnal in their habits, and during the day hide beneath stones along the margins 
of small woodland streams, or beneath logs and chunks in damp woods, in which places seldom less than two, nor more than three or four, are found associated together.

That they are well nigh omnivorous in their choice of food, I have determined by keeping them in eon-

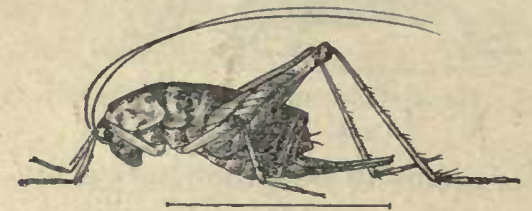

Fig. 53-Stone or Camel Cricket. Ceuthophilus maculatus (Say). (Female, After Lugger.) finement, when they fed upon meat as well as upon pieces of fruit and vegetables, seemingly preferring the latter. The majority of the species evidently reach maturity and deposit their eggs in the late summer or early autumn, as the full grown insects are more common then, but have been taken as late as December 1st. The eggs, which are supposed to be laid in the earth, usnally hatch in April; but some are hatched in autumn and the young live over winter (an anomaly among the Locustidæ), as I have taken them in January and February from the localities which the adults frequent in summer. Several of the species inhabit eaves and are usually of much larger size, with longer antennæ and smaller compound eyes than those found above ground.

\section{GRYLLIDÆ.}

The Gryllide or erickets are, in the main, distinguished from other Orthopterons insects, by having the wing eovers flat above and bent abruptly down- 
ward at the sides; the antennæ long, slender, and many jointed ; the tarsi, or feet, three jointed, without parls between the claws; the ear situated on the tibia of the fore leg, and the abdomen bearing a pair of jointed cerci or stylets at the end.

The ovipositor of the female, when present, is long, usually spear-shaped, and consists, apparently, of two pieces. Each of these halves, however, when closely examined, is seen to be made up of two pieces so united as to form a groove on the inner side; so that when the two halves are fitted together, a tube is produced, down which the eggs pass to the repository in the earth or twig fitted to receive them.

Representatives of 25 species of these interesting insects have been taken in Indiana', several of which are exceedingly abundant throughout the State. Among these are two species of burrowing or "mole" crickets" which rank first in size and singularity of structure. When full grown they measure from one inch to an inch and a half in length ; are light brown in color and have

The Mole Crickets. the body covered with very short hairs, giving it a sott velvety appearance. The females have no visible ovipositor, and, externally, may be separated from the males only by the difference in the veining of the uppermost of the wing covers. By their habit of bur-

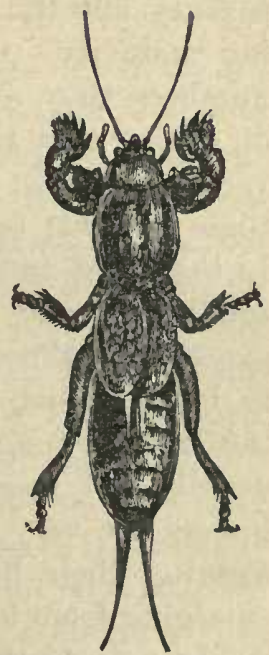

Fig. 54-Mole Cricket. 
rowing beneath the soil in search of such food as the tender roots of plants, earth-worms and the larve of varions insects, the anterior tibin of these crickets have, in the course of ages, become so modified in structure as to closely resemble the front feet of the common mole, whence the generic name, Gryllotalpa, from "gryllus," a cricket, and "talpa," a mole. Moreover, the compound eyes have become very much aborted, being not more than one-eighth the size of those of the common field cricket, Gryllus abbreviatus Serv.; and, as the insect crawls rather than leaps, the hind femora are but little enlarged.

The mole crickets are found in all parts of Indiana, thongh nowhere in great abundance. Their eggs are laid in under-ground chambers in masses of from forty to sixty, and the young are about three years in reaching maturity. On this account, where they exist in numbers, they are very destructive, feeding, as they do during that time, mainly upon the tender roots of various plants. It is therefore fortunate that with us these crickets are not more common than they are. In the moist mud and sand along the margins of the smaller streams and ponds their runs or burrows, exactly like those of a mole, though much smaller, can in late summer and early autumn be seen by those interested enough to search for them. These runs usually end beneath a stone or small stick, but the insects are very seldom seen, as they are nocturnal, forming their burrows by night, and scarcely ever emerging from beneath the ground.

The note of the male is a sharp di-syllabic chirp, continuously repeated and lond enough to be heard 
several rods away. It is usually attributed, by those who have given little attention to insect sounds, to the field crickets or to some of the smaller frogs. They are very difficult to locate by this note, and I have on several occasions approached cautiously on hands and knees, a certain spot and have remained silent for some minutes while the chirping went on, apparently beneath my very eyes; yet when the supposed exact position of the chirper was determined and a quick movement was nade to unearth him he could not be found. Indeed, it is only by chance, as by the sudden turning over of a log in a soft, mucky place that a person can happen upon one of them nuawares. Even then quick movement is necessary to eapture him before he scrambles into the open month of one of the deep burrows which he has ever in readiness.

Probably the best known erickets in the State are the "field erickets" - those dark-colored, thick-bodied species, mature specimens of which are so abundant from late summer until after heavy frosts, beneatl logs, boards, stones, and especially beneath rails in the comers of the old-fashioned and rapidly disappearing

The Field Crickets. rail fences. The eggs of some of the field crickets are laid in the ground in late autumn and hatch the following May. Those of at least two species are, however, laid in late summer or early antumn, and hatch before frost, the half grown young being found in numbers thronghout the winter beneath logs and chunks. On cold days they are usually found in a dormant condition, each one at the bottom of a cone-shaped eavity 
which it has formed for itself, and which is very similar to the pit made in loose sand by the larva of the ant Jion, Myrmeleon obsoletus Say.

The most common of the five species occurring with us is the short-winged field cricket, Gryllus abbreviatus Serv., which is nocturnal, omnivorous, and a cannibal. Avoiding the light of day he venfures forth, as

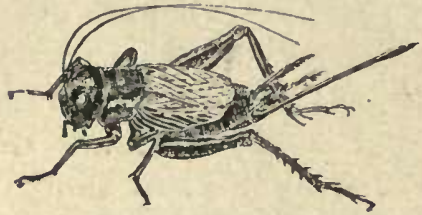

Fig. 55-Field Cricket.

(Female.) soon as darkness has fallen, in search of food, and all appears to be tish which comes to his net. Of fruit, vegetables, grass and carrion he seems equally fond, and does not hesitate to prey upon a weaker brother when opportunity offers. I have often surprised them feasting mpon the bodies of their companions, and of about forty imprisoned together in a box, at the end of a week but six were living. The heads, wings and legs of their dead companions were all that remained to show that the weaker had suecumbed to the stronger; that the fittest, and in this case the fattest, had survived in the deadly struggle for existence.

Of all the Gryllide which oceur in the Northern States, the little brown "ground crickets" are the most numerous and the most social. Unlike their larger cousins, the field crickets, they do not

The Ground Crickets. wait for darkness before seeking their food ; but wherever the grass has been cropped short, whether on shaded hillside or in the full glare of the noonday sun along the beaten roadway, mature specimens may be seen by hundreds 
during the days of early antumn. They are all of small size, being seldom more than half an inch in length. The color is a dark brown, and the bodies and legs are sparsely clothed with brown hairs.

These crickets are omnivorous, feeding upon all kinds of decaying animal matter as well as upon living vegetation. When disturbed they are very diffieult to capture, making enormous. leaps with their stout hind legs, no sooner striking the ground than they are up and away again, even if not pursued, until they find a leaf or other shelter beneath which to take refuge. Six species ocenr in Indiana and from their enormous numbers, as well as from the fact that they are constant, greedy feeders from the time the eggs hateh in the spring until laid low by the hoar frost of antumu, it follows that they must be elassed among our most injurious Orthoptera, but as

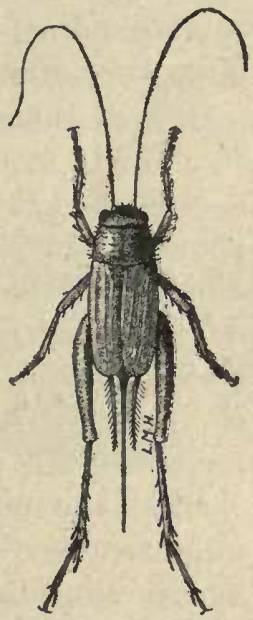

Fig.56-Ground Cricket. Nemobius fasciatus vittatus Harris.

(Female, twice natural size. After Lugger.) yet no effective means for their destruction has been discovered.

Among the crickets occurring in Indiana is a short, thick-borlied brown form, Apithes agitator Uhler. It has been taken in several of the south-western counties, notably in Vigo, where the first ones discovered were on the slender twigs of some prickly-ash shrubs which grew in a damp upland woods. The place was visited a number of times and the crickets were always 
found, perfeetly motionless, and immediately above or below one of the thorns or prickles jutting forth from the twigs. The tips of the hind femora were raised so as to project above the body, thus eausing them to resemble the thorns; and the color of the insects, corresponding closely with that of the bark, made them very difficult to diseover even when in especial search of them. On every clump of prickly-ash in the woods mentioned a number of speeimens were secured but they eould be found nowhere else thereabouts. On another occasion they were discovered abont the roots of a scarlet oak, Quercus coccinea Wang, which grew on a sandy hillside. Here they were plentiful, and resting motionless in the depressions of the bark or beneath the leaves in the cavities formed by the roots of the tree.

Of all the males taken in both places, over thirty in number, there was not one with perfect wing covers, and, in almost every instance, the wing covers as well as the rudimentary wings were wholly absent; while every female had both pairs unharmed. I at first ascribed this wing mutilation to the males figlting among themselves, but finally diseoverer a female in the act of devouring the wings of a male. Why this curious habit on the part of the one sex? Possibly the females require a wing diet to requite them for their bestowed affections, or, perehance, they are a jealous set, and, having once gained the affections of a male, devour his wing covers to keep him from ealling other females about him.

The tree crickets may be known from others of their kin by their slender hind legs, their narrow, 
elongated chest or pro-thorax, and their whitish or greenish-white color. The wing covers of the females

The Tree

Crickets.

are wrapped closely about the body, while those of the male are much

firmer in texture, broadly spread out, and very transparent; causing such a difference of appearance between the two sexes that tyro collectors often take them for widely different insects. Of the six species known to occur in Indiana the snowy tree ericket, Ecanthus niveus DeGeer, is the most common and the best known. Both sexes of this species are in color ivory white, more or less tinged with a delicate green, especially in the
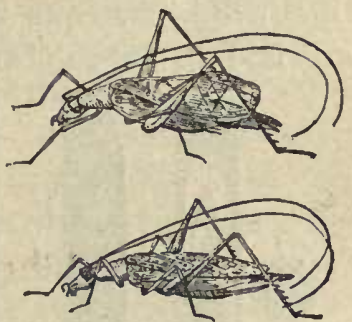

Fig. 57-Snowy Tree Crickets.

(Male and female.) female. The top of the head and basal joint of antennæ are usually suffused with ochre yellow, while on the lower face of each of the two basal joints of the antennre is a small black spot. The ovipositor of the female is short, perfectly straight and usually tipped with black.

The snowy tree cricket is very common throughout the State, and mature specimens are to be found in numbers about grape rines, shrubbery, ete, from August 1st until November. The females appear more plentiful than the males, the latter being more often heard than seen. During the day they keep themselves hidden among the foliage and flowers of various plants, but as night approaches they come forth and the male begins his incessant, shrill, chirp- 
ing note-the well known $t-r-r-r-e-e ; t-r-r-r-e-e$, repeated without pause or variation about seventy times a minute.

The females of the snowy cricket do much harm by ovipositing in the tender canes or shoots of various plants, as the raspberry, grape, plum, peach, ete.; no less than 321 eggs, by actual count, having been found in a raspberry cane 22 inches in length. The eggs are laid in autumn and at first the injury is shown

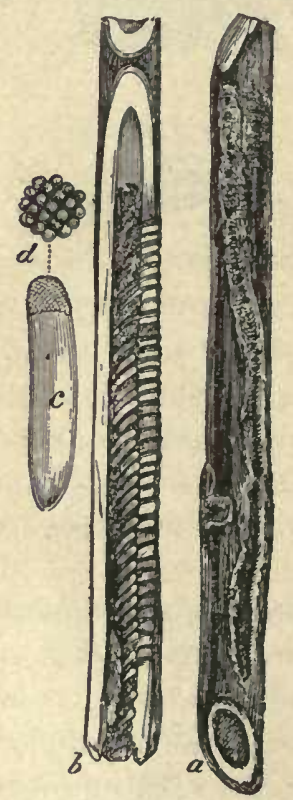

Fig. 58-Eggs of Tree Cricket in raspberry cane.

$a$, Cane, showing puncture; $b$, cane split to show eggs; $c$, egg

enlarged. $\quad$ interesting accolnt of some $\mathrm{ex}$ periments and observations concerning this habit,

only by a slight roughness of the bark, but afterwards the cane or branch frequently dies above the puncture, or is so much injured as to be broken off by the first high wind. If the injured and broken canes containing the eggs be collected and burned in early spring the number of illsects for that season will be materially lessened.

This injurious habit is partly, if not wholly, offset by the carnivorous habits of the crickets, as the young, which are hatched ill June, feed for some time upon the various species of aphides or plant lice which infest the shrubbery they frequent. Miss Mary E. Murtfeldt, of Kirkwood, Mo., has given an interesting account of some ex-

$$
\text { . }
$$


from which the following extract is taken: "Some leaves of plum infested with a delicate species of yellow aphis were put into a jar with the young of Ecarthus niveus, but attracted no immediate attention. As twilight deepened, however, the crickets awakened to greater aetivity. By holding the jar against the light of the window, or bringing it suddenly into the lamp light, the little nocturnal hunters might be seen hurrying with a furtive, darting movement over the leaves and stems, the head bent down, the antenure stretched forward, and every sense apparently on the alert. Then the aphides provided for their food would be caught up one after another with eagerness and devoured with violent action of the mouth parts, the antennæ meanwhile playing up and down in evident expression of satisfaction. Unless I had provided very liberally not an aphis would be found in the jar the next morning, and the sluggish crickets would have every appearance of plethora."

\section{ACRIDID A.}

The common things about us, those which we meet in our every-day life, are usually those of which we know the least. Everybody knows a grasshopper by sight. How many can describe the salient points in its life history, can tell of the many devices which it uses to avoid its enemies, or of the many ways in which its organs have become adapted to or fitted for the life it leads? Yet any one interested in the objects of nature can soon learn these and other similar facts 
for himself by a little patient, personal investigation.

To the people of ancient times the "grasshopper" of to-day was the "locust," one of the seven plagues of Egypt. The scientific men of this country have long endeavored to have them ealled "locusts" in the United States, but the majority of people persist in ealling them "grasshoppers," and give the name "locnst" to those noisy insects which once every seventeen years invade our fields and forests in such countless numbers. To niy mind "grasshopper" is the better and more expressive name for the insect with which we have to deal, and, though "locust" has the priority, as the wise men say, yet we shall relegate it to the shades of the past and know our subject by its most common title.

To the average observer a grasshopper is a grasshopper, nothing more-like

"The primrose on the river's brim"

was to Peter Bell. But to the naturalist, or to any person who will keep his eyes and ears open as he walks about, there are grasshoppers and grasslioppers-not individuals, but different kinds, each with interesting facts to be learned concerning it. Over 520 species inhabit the United States, 51 of which have been taken by myself within the limits of Indiana.

Most of these pass the winter in the egg stage, the eggs, in early autumn, being deposited in the earth ly the mother insect in compact masses of forty to sixty each in the manner shown in the accompanying cut. About mid-April these eggs begin to hatch and 
the sprightly little inseets, devoid of wings but otherwise like their parents, are soon seen on every hand.

Born with one earthly desire-a voracious appetite -and with one valuable possession-a pair of strong,

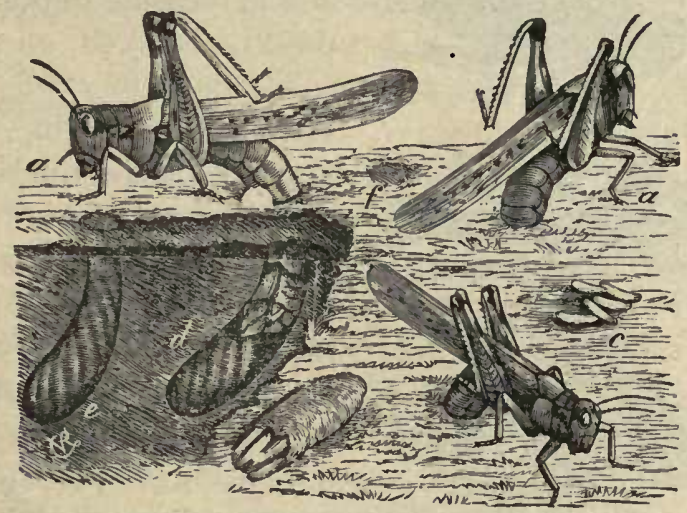

Fig. 59-Grasshopper in the act of laying eggs. (After Riley.)

broad jaws, which move in and out like the blades of a pair of scissors-the little bopper soon begins to use The Young of the latter to appease the former, and Grasshoppers. for twenty-four hours a day and seven days in a week, he gnaws away at the soft, green, sucenlent grass which surrounds him on every side. Such a procedure can have but one result. His body soon beeomes too big for its surroundings. Something must give way and that something. is his skin. He easts it aside with but little reluctance, however, for a new one is ready to take its place, and immediately begins to satiate his appetite once more. Five sucessive times his skin gets too small for his body and is cast aside. Between each 
of these moults the wings are growing and when the fifth skin is shed he emerges a mature and fully fledged insect.

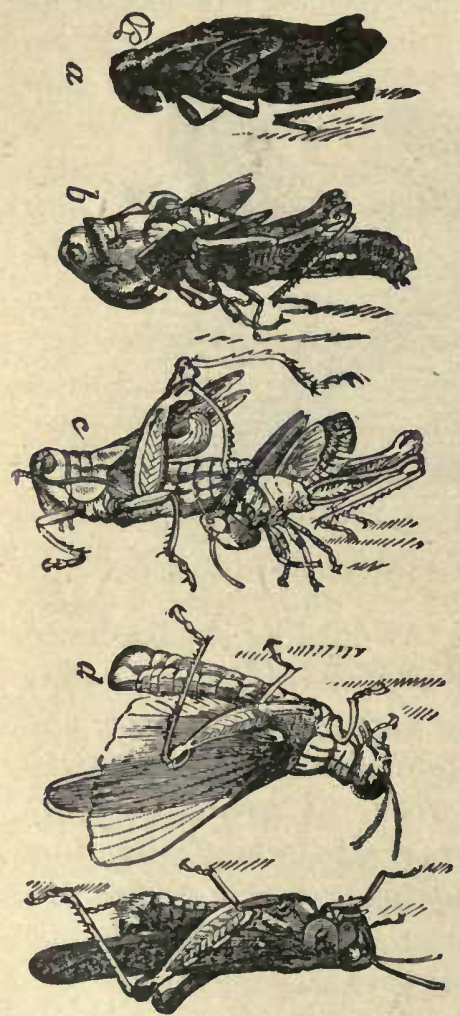

While passing through a field on one September day, I observed, elinging to the stems of weeds, several specimens of what appeared to be the bodies of grasshopper's with the wings of the common sulphur-yellow butterfly attached to them. Such à combination aroused $\mathrm{my}$ curiosity, but a close examination proved them to be specimens of the eommon black-winged grasshopper which had just moulted for the last time and spread out their soft wings to dry. The inner wings, instead of being black, were light yellow, but in three or four hours thereafter had ehanged to their usual color. The Fig.60-Grasshopper shedding its skin. cast off skins were close (a, Young ready to change; $b$ and $c$, the by and were nuch smaller skin splits along the baek and the adult emerges; $d$, adult drying out; $e$, perfect insect. After Riley.)

than the insect. Like crayfish they had shed the entire outer skin in one piece, pulling out the legs 
and antennæ much as a person pulls a foot out of a boot.

However, all grasshoppers do not pass the winter in the egg state. Three or four species hatch in early autumn and the young in various stages can, in suitable localities, be seen jumping vigorously

Winter Grasshoppers. about on any warm sunny day in mid-winter. If their presence at such a season comes to the attention of a newspaper reporter, the press of the entire State is apt to teem with warnings of a coming grasshopper plague, of which the youngsters are thought to be the advance guard. These hibernating young are the first to reach maturity the next spring, usually becoming full grown about the 20th of April.

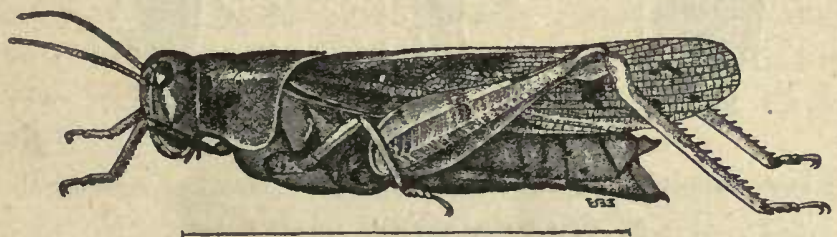

Fig. 61-Coral-winged Grasshopper, Hippiscus tuberculatus (Pal. de B.). (Survives the winter in young stage and reaches maturity in April. After Lugger.)

Again, nine species out of our fifty-one pass the winter as mature insects. They are our smallest grasshoppers, all being, when full grown, less than half an inch in length; gray or blackish in color; and with the hard upper erust of the

Grouse Grasshoppers. thorax extending the full length of the body and covering the wings. They are called "grouse grasshoppers," and during cold weather they hide bencath the loose bark of logs 
or beneath the bottom rails of old fences. On the first warm days of spring they can be collected by hundreds from any grass-eovered hillside having a sunny southern exposure.

A grasshopper has five eyes, three small simple ones, and two large compound ones. Each of the latter is composed of many thouaand six-sided facets or parts, in each of which a single filament of the optic nerve'ends; yet it is claimed that with all these
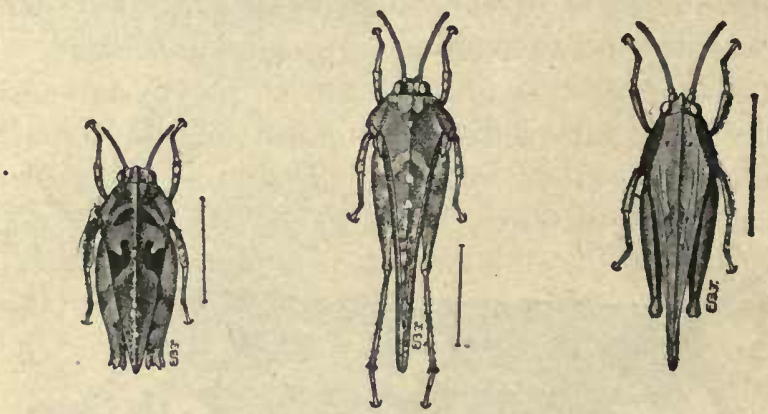

Tettix ornatus (Say). Paratettix cucullatus (Burm). Tettigidea lateralis (Say).

Fig. 62.-Grouse Grasshoppers. (After Lugger.)

eyes the inseet sees but poorly, being guided rather by the sense of smell than by that of sight. There is no nose, the sense of smell being located in the feelers or antennæ; while the ears, instear of being in the head, are on the basal ring of the abdomen. Ten small openings on each side of the body lead into tubes which branch and ramify through all its portions. Throngh these the air passes and comes in contact with the blood vessels which lie alongside of the air tubes in many parts of the body. 
As is well known, the male of each species of grasshopper has the power of making a peculiar noise, or "stridulation," as it is called. In most species it is made while on the ground and is produced by rubbing the inner surface of the hind leg "Songs" of against the outer surface of the front wing. In those species which fly much it is made while on the wing, or just when rising from the ground, by rubbing together the

- upper surface of the front edge of the hind wings and the under surface of the front wings. By paying close attention the observer can soon learn to distinguish each species by its peculiar note. Only the males liave musical organs, which is quite the reverse among some animals higher in the scale of life where the females make most of the music and oftentimes much of the noise. The female grasshoppers, however, make up for their lack of musical abilities by their greater bulk, as they are always much larger than their better (?) halves.

Nineteen out of our fifty-one species seldom nse the wings in moving from place to place, but leap vigorously when disturbed. Among them are seven species of "short winged" grasshoppers whose wings have become rudimentary in the past through long clisuse, so that in the perfect insect of to-day they are less than half the length of the abdomen.

Fifteen kinds, the most common of which is the black-winged or "Carolina grasshopper," use the wings almost wholly in their jaurneyings and often fly long distances when flusherl. Their hind legs are used only in giving themselves an upward impetus 
from the ground and hence are much smaller proportionally than are those of the group of "hoppers" which leap rather than fly, while their wings are much longer and stronger. To this group of "Hyers" belongs our largest and most handsome species, the "American grasshopper," Schistocerca americana (Drury).

In the season of 1893 this species was unusually common in Vigo County, from the fact that a large number of adults were blown in by a high wind which prevailed on the night of April 11. No mature specimens had ever before been noted in that vicinity

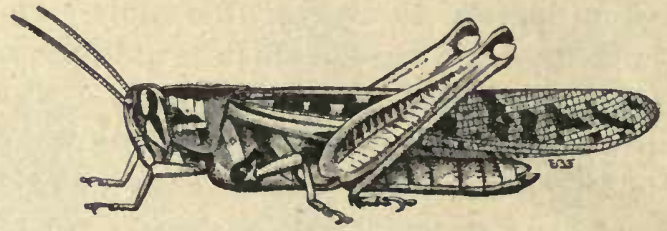

Fig. 63-Ameriean Grasshopper.

(Male. After Lugger.)

earlier than the middle of June, but on the morning after the storm mentioned hundreds were seen on the streets of Terre Haute. They had come sailing in on the wings of the wind from some distant point in the sonth-west where they had passed the winter in the mature state or as an advanced form of the young.

In Indiana there are two species which far ontrank all others in numbers and in the injury which they do to grass and growing vegetation in general. The larger of these is the "lubberly grasshopper," Melanoplus differentiulis (Uhler), a clunisy, thick-set fellow, which is found by thousands along fence rows and 
the borders of cultivated fields, especially those of the river bottoms, where they feed upon the greater ragweed or horse-weed. On October 2d, 1894, vast numbers were seen along the edge of a tield of low-

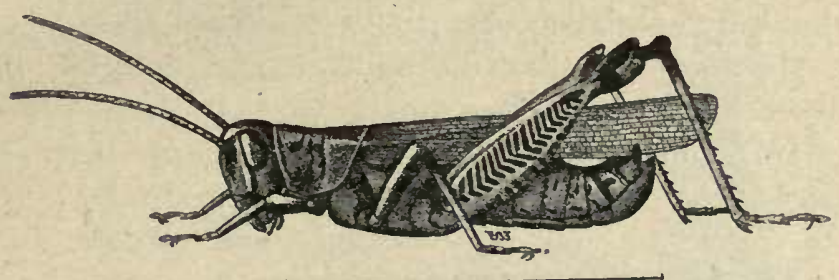

Fig. 64-Lubberly Grasshopper.

(Male. After Lugger.)

land corn, the leaves of the marginal rows of which they had almost wholly destroyed. When a stalk was approached they did not desert it but dodged quickly around to the opposite side, much as a squirrel does around the trunk of a tree when pursued. If, however, one took alarm and jumped, all the others in the immediate vicinity did likewise.

The most eommon and most injurious species found in the State is much smaller and is known as the "red-legged grasshopper," Melanoplus femur-rubrum (DeGeer), on account of its hind shanks or tibire being blood-red. It often destroys the second erop of clover in many parts of the State, besides doing much injury to young eorn and other growing erops.

The Kansas or Rocky Mountain grasshopper does not oceur in Indiana. Contrary to the general belief

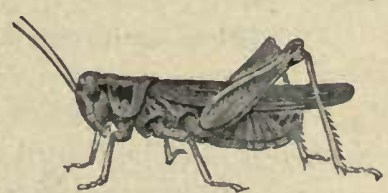

Fig. 65-Red-legged Grasshopper. (Male.) 
it is not a large, robust species, being but about the

The Kansas same size as our red-legged grasshopGrasshopper. per, and bearing to the latter a close general resemblance; so close in fact that only specialists can readily tell them apart.

Millions of dollars of damage was done in the Western States by these small insects in the summers of 1873 and 1875 . Migrating in vast elonds from one part of the comntry to another they would fall upon a

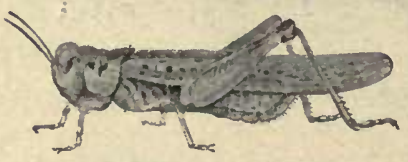

Fig. 66-Kiansas Grasshopper. Melanoplus spretus (Uhler). (Male.) cornfield and eonvert, in a few hours, the green and promising acres into a desolate stretch of bare, spindling stalks and stulss. In the words of the prophet Joel: "The land was as the garden of Elen before them, and behind them a desolate wilderness; yea, and nothing did escape them."

The sound caused by their approach or flight was ahnost deafening, and has been graphically described at follows:

"Onward they came, a dark continuous cloud Of congregated myriads number!ess,

The rustling of whose wings was as the sound Of a broad river headlong in its course

Plunged from a mountain summit, or the roar Of a wild ocean in the antumn storm,

Shattering its billows on a shore of rock."

Each kind of grasshopper has its favorite resort where it is to be found in greatest abundance, although some of them are common enongh anywhere. For example, there are three or four species of pea-green 
grasshoppers which are found only among the dense green grasses and sedges along the margins of ponds and lowland streams. There, as long as motionless, they are invisible, and there they flourish in peace and countless numbers.

The Kentucky blue-grass and the different kinds of meadow grasses are a darker green, and, where rank, turn brown early in the autmmn. The different species of "shortwinged" grasshoppers, and many other's whose hues are olive green or brown, find in the fallen clumps of these grasses places of hiding well suiting their color as well as an abundance of food well suiting their taste.

At the Goose Pond, nine miles below Terre Haute, occurs a speeies of grasshopper, Leptysma marginicollis (Serv.), which has never been re-

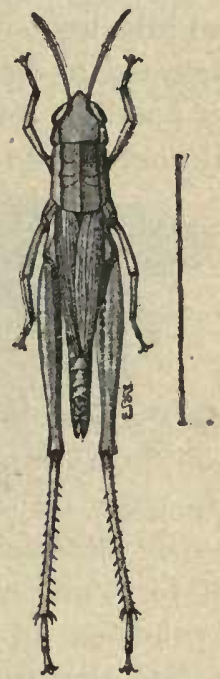

Fig. 6i-A Pea-green Grasshopper.

Dicromorpha viridis (Seudder).

(After Lugger.) corded elsewhere north of Florida. Its occurrence in Indiana can only be accounted for by the presence of the broad and sheltering valley of the Wabash within the confines of which it finds a climate and a vegetation congenial to its wants. If its habits be the same elsewhere as in Indiana, the name "grasshopper" is for it a misnomer, for here it is never seen on the grass or ground, and never hops when disturbed, but moves with a quick and noiseless flight for twenty or more feet to a cylindrical stem of sedge or rush on which 
it alights. The instant it grasps the stem it dodges quickly around to the side opposite the intruder. Then, holding the stem firmly with its short front and middle legs, it draws its sleuder hind legs close up against the body and hugging its support as closely as possible, remains perfectly motionless. Its body is almost cylindrical, and being of the same general

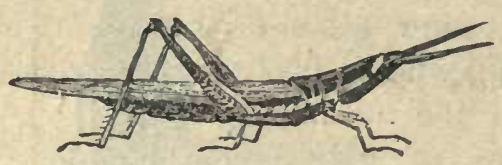

Fig. 68-Florida Grasshopper.

color as the stalk of the plant on which it rests, it is almost impossible to detect it, unless one sees exactly where it alights. Eight times out of ten a person, by approaching quietly, can reach his hand about the plant stem and grasp the insect. Its habits excellently illustrate the so-called "protective mimicry" of form and coloring, as it always seems to choose a cylindrical object, and one similar to its own color, before alighting.

Let us now briefly notice the habits of our ashbrown, black-winged friend, the "Carolina grasshopper." To the casual observer he appears to be our most common species but there are a dozen which are more abundant. His numbers appear multiplied because he frequents the highways and byways of man rather than the pastures and meadows where other grasshoppers are wont to congregate. Moreover, when disturbed, he more often betakes himself to the bare earth than to the green grass. "Why this absurd taste?"-asks the person uninitiated in the doings of nature's oljects. For the simple reason that the dust of the roadside and the gravel ballast of 
the railway correspond so closely with the color of his back that his best friends and worst enemies will overlook him if he will only remain quiet. Yea, even that sharp-eyed connoisseur of grasshopper tidbits, the turkey gobbler, oftentimes walks right over him mistaking him for a wayside pebble.

Thus, by choosing their resorts to suit their colors, or rather, in the course of ages, changing their colors to suit their. environments, grasshoppers have been enabled each

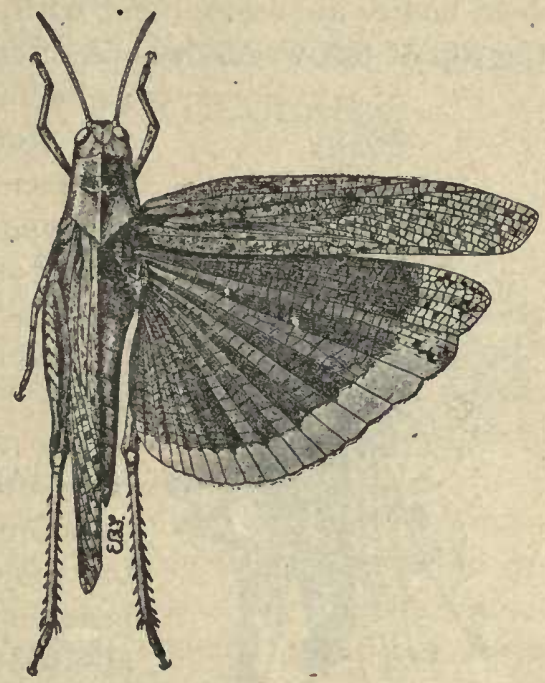

Fig. 69-Carolina Grasshopper.

Dissosteira carolina (L.).

(After Lugger.)

year to wax, grow fat, and replenish the earth with their progeny, at the same time deplenishing it by reason of their enormous numbers and their insatiable appetites.

In the latitude of central Indiana, the heyday of the mature grasshopper's life lies between the dates of mid-August and mid-October. Then it is that their love calls are the most numerous; that their ambitions in life are satisfied, and that the eggs, destined to carry the race through the rigors of an approaching 
winter, are deposited in the earth. As the cooler days of November draw nigh their rauks grow rapidly less, and yet, with the exception of one place, their lead bodies are seldom met with. That exception is the top of tall weeds, where, oftentimes even so early

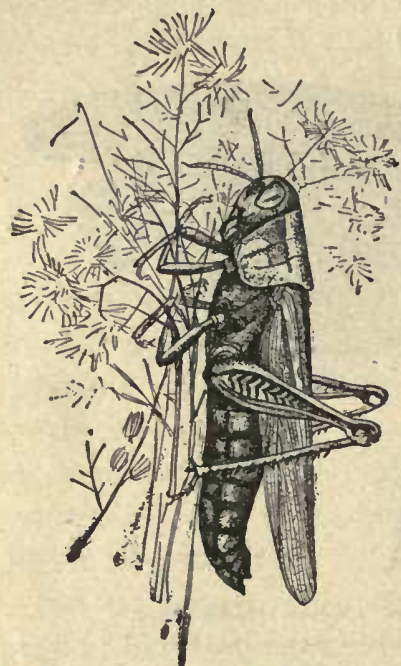

Fig. 70-Two-striped Grasshopper.

Melanoplus bivittatus (Say).

(Killed by a fungus. After Lugger.) as September, the bodies of the more common species are seen, their limbs tightly clasping the branches or leaves of the plant on which they rest. Why this position is taken by them before death I can not say. Of course it is nonsense, but I have often askerl myself the question: Is it assuming too much of them to suppose that, having lived their allotted time, or being preyed upon by some invisible but insidious animal or plant parasite, and feeling their death throes coming on, they choose to fly or climb to the most elevated position available, there to take a farewell view of their summer's home? 


\section{WEEDS IN GENERAL AND OUR WORST WEEDS IN PARTICULAR.}

What is a weed? How does it differ from a wild flower? These questions are often asked by persons who are beginning the study of botany; and pupils have been known to put aside a specimen with a look of disgust, saying at the same time that they "did not want to study that nasty weed."

There is, of course, no differenee, botanically speaking, between a weed and a wild flower, save that of comparative abundance. Sonie of our most common weeds are among the most handsome of our wild flowers; for example, the iron-weed, thistle and oxeye daisy. They well illustrate the truth of that old saying that "familiarity breeds contempt," for we

- have become so familiar with their appearance that we daily pass them by unnoticed. Were they as rare as the showy orehis and wild columbine they would no longer be called "weeds," but "wild flowers," and would, perhaps, be enltivated for ormanent; just as among half the collections of house plants in Indiana are found species of eacti which are by no means rarities to the natives of Texas and New Mexico.

A weed has been defined as "merely a plant in the wrong place," but Grant Allen, a noted English botanist, in speaking of this definition says that it is far 
more than that, and that the term "weed" implies something further than mere abstract hostility to the agricultural interest; it "implies a certain ingrained coarseness, scrubbiness, squalor and sordidness, besides connoting, in nine times out of ten, some stringiness of fibre, hairiness of surface, or prickly defensive character as well." Of most weeds this is true, but it is the possession of just such characters that has enabled them to succeed so well in crowding out and displacing other wild and cultivated plants which, perhaps, were in the right place, and in taking, if unmolested, entire possession of the soil.

Weeds are, of course, among the worst enemies with which the farmers and market gardenels have to deal, and the questions of eradication, quarantine, and the like are becoming each year of greater state and national importance.

Each locality, and each farm for that matter, has its worst weed, the species depending upon climate, soil, method of cultivation, etc. Indeed there is no spot on earth, unless it be a desert, where they do not abound. A few years ago Mr. Byron D. Halstead asked, through the Botanical Gazette and other periodicals, that a list of the 20 worst weeds, in the order of their injuriousness, in any locality or territory in the United States, be sent to him. He tabulated the repcrts which he received from all parts of the country and found that 34 species had been mentioned at least five times in the lists. Of these 34 , no less than 32 are known to occur in Indiana, though some of them only in a few localities of the State. Taking from the list of 34 the 20 species which were consid- 
ered the most injurious, all of them are represented in Indiana; although the order of injuriousness here, is, in my opinion, not the same as that given in Mr. Halstead's list.

The Canada thistle and eouch or quick grass, which are ranked first and second in his list, are, as yet, found only in restricted areas in northern Indiana. The common names of the remaining 18 species of the list in the order given are as follows: Cocklebur, bur-grass, erab or finger grass, rag-weed, field sorrel, pig-weed, horse-weed or great rag-weed, fox-tail, lamb's-quarters, ox-eye daisy, purslane, curled doek, barn-yard grass, bind-weed, shepherd's purse, common thistle, burdock and jimson.

Each of these weeds has its favorite locality of growth; for instance, the great rag-weed, cocklebur and bind-weed are found almost exclusively in the rich alluvial soil of the bottoms; burdock and jimson-weed in waste grounds about stables and old dwellings; rag-weed and foxtail in cultivated upland soil ; bur-grass along the sandy banks of streams, and so on through the list.

To the botanist, one of the most interesting points in eonnection with these 20 weeds is the fact that 15 of them are introduced or foreign plants which have become naturalized from Europe or Asia; the two rag-weeds, bind-weed, bur-grass and couch-grass comprising the five American or native species. Indeed, America seems to be not only the "home for the oppressed of all nations," but her soil seems to suit exactly those weeds which are the off-seourings and refuse of eivilization in all countries. Grant Allen 
expresses it well when he says that in "civilized, cultivated, and inhabited New England, and as far inland at least as the Mississippi, the prevailing regetation is the vegetation of central Europe, and that at its weediest. The daisy, the primrose, the cowslip and the daffodil have stayed at home; the weeds have gone to colonize the New World. For thistles and burdock, dog-fenncl and dead-nettle, hound's-tongue and stick-seed, catnip and dandelion, ox-eye daisy and cocklebur, America easily licks all creation. All the dusty, noisome, and malodorous pests of all the world seem there to revel in one grand, congenial, democratic orgy."

Of the plants deseribed in Gray's "Manual of Botany," as growing east of the Mississippi and nortl of North Carolina and Tennessee, 293 are introduced species, 27 of which are natives of tropical America, the remaining 266 having found their way here from Europe; while 342 other species are common to the north-eastern United States and Europe. Thus an American botanist crossing the Atlantic could find, growing indigenously in Europe, no less than 608 species of plants which he was accustomed to see at home and they among the most common ones found here.

An interesting history of the numerous ways in which the Old World weeds have been introduced into this country could, no doubt, be written it one had all the facts. One instance of how a single species found its way from Gemany to this State will serve as a type of the method of introduction. While a student at Indiana University, I was engaged for a time in 
working up the flora of Monroe County, and one day happened upon a strange species of the Compositce, or sunflower family of plants, growing in the new college eampus. It proved a puzzler, and after spending the better part of my spare tirne for two days in endeavoring to find its name, a specimen was sent to Professor Dudley, the botanist at Cornell University, for identification. He, having traveled in Europe, immediately recognized it as a pernicious weed common on the continent, but not before reported from any part of the United States. The next question was, how had it found its way into that remote corner of Indiana? It was easily answered. A new supply of glassware for the chemical department of the University had, the fall before, been purchased in Germany, and the straw in which it had been packed was thrown on the ground and left for a day or two on the very spot where the plant had afterwards appeared. The three specimens which sprang up were destroyed before maturing their seeds and the spread of the weed throughout the country was thereby prevented.

But all the weeds introduced into this State in recent years are not foreigners or deseendants of foreigners. The supply of new species from Europe is about exhausted, and the great plains of the west and southwest, admirably adapted by nature for the evolution of weeds of eultivation, are rapidly sending eastward their own rich contingent to compete with the trans-Atlantic types for the mastery of our soil. Twenty years ago there started eastward from the base of the Rocky Mountains, the bristly cone-flower and the fetid marigold, two members of the great 
Composito order. To-day they have a foothold east of the Mississippi, along every roadside and in every meadow suitable to their growth. Two specimens of Texan nettle (Solanum rostratum Dunal) were recently found in a field north of the city of Terre Haute. This plant is given in Prof. Halstead's list as one of the 34 worst weeds in the United States. Its habitat, or usual range, is given in the botanies as "Pläins of Nebraska to Texas," but it is rapidly moring northward and eastward, and unless checked in its course will soon bring dismay to thousands of farmer's who know nothing of its pernicious habits.

These plants in their eastward migration are well up to the spirit of the times. They travel by railway. The seeds are carried either in the coats of cattle or sheep or in the food which supports them on their journey. Our great railways run east and west and the bared soil alongside the traeks furnishes excellent seed beds, where, if dropped, the seed may sprout and the plant grow unmolested, until it gets a chance to take another step in advance. The botanist has learned their ways of migration and knows that if he wishes to find strange species his best pathway will be alongside the railways.

Taking the term "weed" in the sense of useless plants growing wild in cultivated grounds, pastures and meadows, of sufficient size to be easily noticeable, and of sufficient abundance to be injurious to the farmer, 91 species were found by myself in Vigo County and as many may be found in almost any county in the State. Of these, according to Gray, 33 are of European origin; eight are from tropical 
America; two from Asia; the remaining 48, natives of the United States.

In my opinion the following list comprises the 20 worst species of weeds growing in Indiana, and named in the order of their injuriousness. Both common and scientitic names are given, together with the original home of each species:

1. Rag-weed, Ambrasia artemiscefolia L.-United States.

2. Foxtail, Setaria glauca Beauv.-Europe.

3. Iron-weed, Vernonia fasciculata Michx.-.United States.

4. Great Rag-weed, Ambrosia trifida L.-United States.

5. Pig-weed, Amarantus retroflexus L.-Tropical America.

6. Horse-weed, Erigeron canadense L.-United States.

7. Cocklebur, Xanthium canadense Mill.-United States.

8. White-top, Erigeron annuus L.-United States.

9. Lamb's-quarters, Chenopodium album L.-Europe.

10. Common Thistle, Cricus lanceolatus Hoffm.-Enrope.

11. Field Sorrel, Rumex acetoselle L.-Europe.

12. Purslane, Portulaca oteracea L.-Europe.

13. Bur-grass, Cenchrus tribuloides L.-United States.

14. Beggar's Ticks, Bidens frondosa L.-United States.

15. Prickly Lettuce, Laciuca scariola L.-Europe.

16. Crab-grass, Panicum sanguinale L.-Europe.

17. Jimson-weed, Datura stramonium L.-Asia.

18. Smart-weed, Polygonum persicaria L.-Europe.

19. Bracted Bindweed, Convolvulus sepium L.-United States.

20. Corn Cockle, Lychnis githago L.-Europe.

Of these it will be seen that nine are native; nine are from Europe; one from tropical America, and. one from Asia. The first, third and fourth are native, so that all in all the American weeds have held their own quite successfully in the Hoosier State.

And now, we suppose, the question naturally arises: "What is the best method of ridding ourselves of these weeds now that they are here?" In my opinion 
there is no method. They are here and here to stay. The farmers of the future must wage an eternal warfure against them, for they have secured a foothold which ean not be entirely overeome. True, a new species possessing advantages which will enable it to erowd them out, may, in time, appear, but such a ehange would very likely be for the worst.

There was a time when but one, two, or a dozen plants of each of the foreign weeds existed in the State. Then was the time to have sucessfully quarantined that speeies by destroying those pioneers. The few persons on whose lands they appeared neglected them, and every gardener, every farmer, yea, every land owner in the State, must heneeforth, now and forever, pay the penalty of that neglect by eontinued hoeing, plowing and mowing to keep these alien weeds in subjugation.

As long as the rudiments of botany are not taught in the eommon schools the average farmer will be unable to tell whether a new plant which has made its appearance upon his land should be allowed to grow or not; in fact, in many instances, he will not know that a new plant is there until it becomes too abundant to be easily overcome. Put a high sehool into each township in the State; teach the elements of botany therein and then, and not till then, may we hope that the farmers of the future will be on the lookout for all new plants; will be able at once to judge their relative injuriousness; and will destroy, before they have time to ripen their seeds, those species which, if allowed to sprear, would become a curse to the State. 


\section{TWELVE WINTER BIRDS.*}

\section{I.}

The woods and fields in winter are not the silent, deserted places which most people believe them to be. Any person who will look with both eyes and listen with both ears ean detect in them many forms of life -oceupying many strange and wonderful positionsand gaining a livelihood in many quaint and curious ways.

With the wind blowing at the rate of thirty miles an hour, the air thick with filling flakes of snow, and the temperature 15 degrees Fahr., or less, one is, perhaps naturally, disposed to stay indoors and take it for granted that all the birds liave long since departed for the sunny south. But herein mankind sadly errs, for even during such days, both in the woods and fields, there are birds and birds. The ornithologist, strolling for a mile or two beyond the eity limits can on such a day, devoted solely to the observation of his feathered friends, usually detect 30 or more species, while fully 28 additional kinds are found in the State during the winter season. These may be classified among three groups:

First.-Permanent Residents, or those which rear their young here; they or other individuals of their

* First published in Terre Haute Gazette; December, 1893-March, 1894. 
species remaining with us throughout the yearthe quail, erow and jay-bird being familiar examples. Of the 321 birds known to oceur in Indiana, 33 belong to this class.

Second.- Winter Residents. These nest in the - northern.regions and come down each season in late sutumn to spend the winter months with us and cheer us up with their merry chirps, but disappear northward again at the approach of spring. The slate colored snow-bird and the tree sparrow are the most familiar and abundant of the eleven species of this group which oceur in Indiana.

Third.-Winter Visitors. These are birds either from the north or north-west which often drop in upon us to spend a week or two when King Boreas reigns supreme, and the mercury marks daily the zero point or below. The great snowy owl, the red erossbill and the golden eagle are examples of the 14 species of this class which have been noted in the State.

In the wooded portions of Indiana the woodpeckers are among the most noticeable and interesting members of our winter bird fauna. Few are the days from November to April when their peculiar calls

The Wood= and rapid tapping in search of food pecker Fanily. may not be heard. About 250 kinds
of woodpeckers are known, only eleven of which are found in the United States east of the Mississippi river. Of these, seven oceur in Indiana, five of the seven being permanent residents; one, a migrant, is seen here only in spring and fall; while the other one is a summer resident, but often remains in 
small numbers throughout the winter, especially in the southern half of the State.

All belong to the family Picido, a oword derived from the Latin picus, a "woodpecker." The characters by which each nember of this family may be easily known are the stont, straight bill, fitted for hammering or boring into wood; the long, barbed tongue which, like that of the suake or toad, can be darted from the mouth for the purpose of catching insects; the toes in pairs, two in front and two behind, and armed with strong, compressed claws, thus enabling

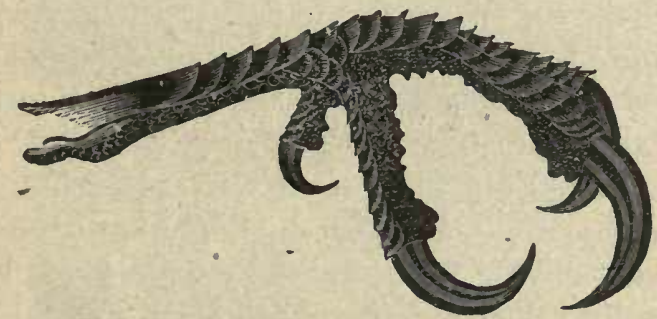

Fig. 71-Zygodactylc or "yolse-tocd" foot of woodpecker.

the bird to get a firm hold upon the trunk or limb of tree; while the tail feathers are not soft and rounded like those of other birds, but are very stiff and pointed at the end, thus enabling the owner to use the tail as a brace and so keep from toppling over backwards while delivering its rapid and powerful blows. The flight, too, of these birds is peculiar, being a sort of wave-like or undulatory progression, instead of a movement directly forward on one level.

One of the most interesting of the five species of woodpeckers found in the State thronghout the year is the subject of the present sketch. It has a number 
of common names, the most familiar of which is the "red-bellied woodpecker." Others are "zebra bird,"

The Red-bellied

Woodpecker.

"woodchnck," or "chuck," "Carolina woodpecker" and "checkered woodpecker;" while its scientific name is Melanerpes carolinus (L.). The first part of this name, Melanerpes, is the name of the genus and corresponds to our surnames of Jones, Brown, etc. It is derived from tiwo Greek words and means "black creeper." The second part, carolinus, corresponds to our given names of John, Mary, etc., although it is always written after the sur or generic name. It is derived from "Carolina," from which region the first specimens were described by Linnæus, the noted Swedish naturalist of the last century.

Thus, each kind of bird, as well as each kind of organic object which has been noted and studied by man, has a double Latin name by which it is known to naturatists in every conntry on earth; while it may have a dozen common names in the restricted locality where it is found. There are thousands of birds of this name in Indiana, but they are all very nearly alike-that is of one species-and hence have the same Latin name; while those woodpeckers which differ materially in size, color, ete., have different Latin names, as we shall see on the following pages.

The red-bellied woodpecker is about ten inches in length from tip of bill to end of tail. The back and wings are very prettily barred with narrow black and white bands, whence the less used but more suitable name of "zebra bird." In the male the entire upper surface of the head and neck is a bright scarlet-red, 
while in the female the crown is ash colored, with the foreliead and nape of the neck scarlet. The whole under part of the body is a grayish ash with a tinge of red ou the belly.

The zebra bird is the hermit among our woodpeckers. He scorns the companionship of other members

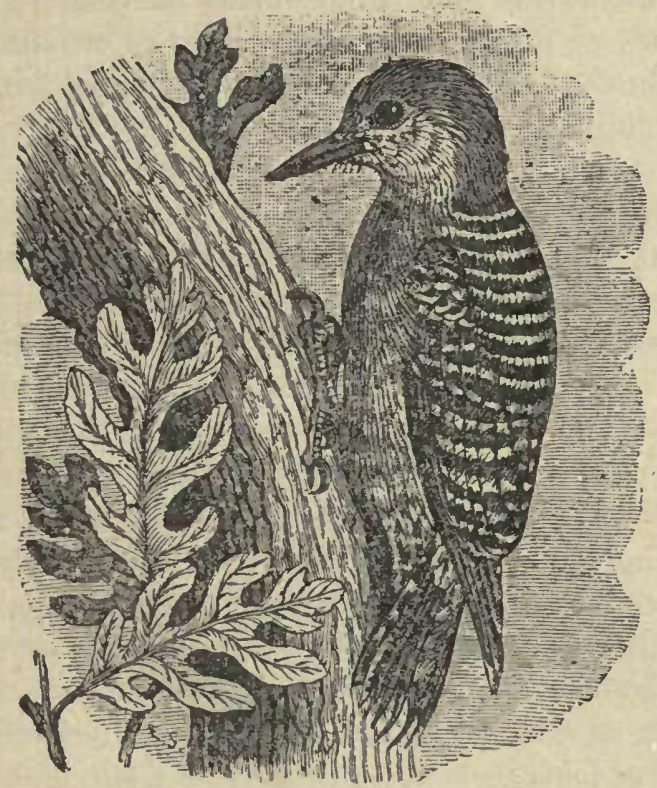

Fig. 72 Red-bellied Woodpecker.

of his family and delights to be alone or in the company of his mate only. During the winter and early spring he may be found along the borders of woodlands, where in the tops of the tallest trees he industriously seeks his food. At intervals he pauses in his work, raises his head and looking around, utters a 
loud "char-char" or "churek, chuck, chuek," and then inmediately resumes his peeking with increased vigor. Rarely in winter, when insect food is scarce, does he visit the-farmer's corn crib and, gaining ingress between the logs or rails, helps himself to a bountiful supply of food.

As the nesting season approaches he, with his chosen mate, seeks the privacy of the deepest woods, where high above the ground in some decaying limb or trunk of tree a place for a nest is excavated. The eggs are four to six in number, pure white in color, and about $1 \times .87$ inches in size.

To the farmer who owns timber land this woodpecker is one of the most beneficial of birds. The number of kinds of insects which prey upon our native forest trees is surprisingly large. The oak harbors between 500 and 600 species; the hickory, 140 ; the walnut, 70 ; the elm, 25 to 30 , and the maple at least 15. To the presence of these inscets, more than to anything else, is the stunted growth and early decay of our timber dne. Thousands of wood-boring beetles, caterpillars, plant lice and young saw-flies are annually destroyed by the zebra bird. On this account the farmers who have not already made his acquaintance, should at least seek to know him by sight, and always protect him and his young from their now most dangerous enemies, the small boy with his musket and the eity sportsman with his shotgun.

In autumn, especially, the woods and fields throughout the State are full of these self-styled "hunters," ready at a moment's notice to bring down any bird larger than a sparrow, any animal above a field mouse 
or a chipmunk. No feeling of sorrow ever enters their minds as they gaze into the eyes of some cruelly wounded bird or animal and see the life force, which they can never recall, slowly ebbing away. The woodpeckers, in particular, suffer from their heedless shooting. Hundreds of then are daily shot down and left where they fall, for the sole purpose of showing the hunter's skill in marksmanship, or to satisfy that craving desire to kill objects below him in the scale of life which blinds him to every feeling of pity, every sense of remorse.

To those who have been accustomed to pass the cold season in the city, exempt for nouths fron the pure, bracing, country air, I would say: Go forth and study nature on some sunny day in mid-winter. You will not find the woods full of thrushes, warblers and other songsters ready on every hand to greet you. They are effeminate birds, joyous only in the presence of plenty of blue sky and sumshine, and Jack Frost has long since driven them to seck a sumny, southern clime where food is more plentiful than here. But yon will find their rugged cousin, the zelora bird, clinging to the side of a dead stub and deriving pure inspiration therefrom. You will see lim fluft his feather's about his bare toes to keep them warm while he makes the woods reverberate with his cheery call-and from him, if yon are wise, you may learn a lesson of happiness and contentment. 


\section{II.}

He, who would become acquainted with our common birds, must seek them in their chosen haunts; for in the ages of the past each kind has beeome fitted or adapter to live a certain life-to seek its food in a certain place. In the spring, keen-eyed, sharp-eared robins hop leisurely over the surface of our lawns and gardens and drag earth-worms and cut-worms galore

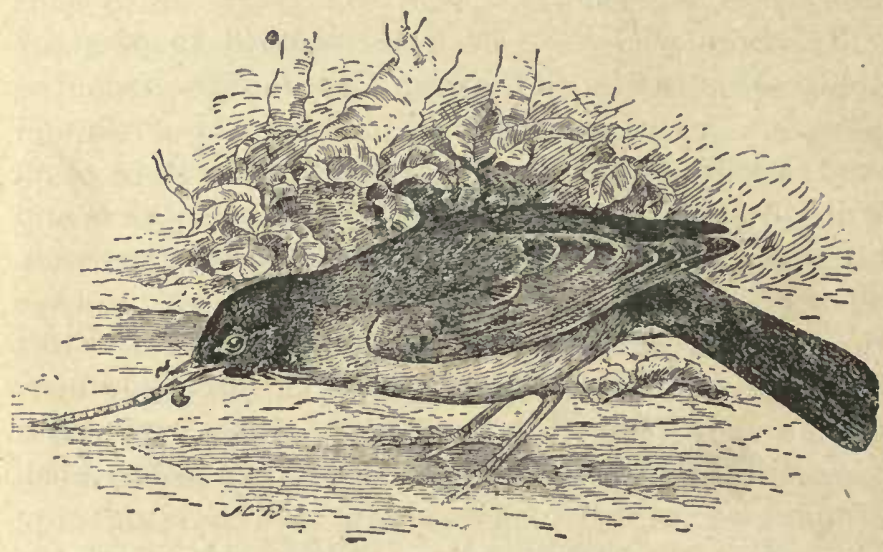

Fig. 73-Robin. (After Beal.)

from their hiding-places; long-legged snipe wade the shallow water along the margins of ponds and streams and probe with their long, soft bills the nuck and mud in search of worms and leeches; web-footed wild dueks swim and dive in ponds and rivers, silting through their broad lamellate bills the mud and ooze for small fish, shrimps, and other water-loving forms; 
wide-mouthed swallows cleave the air in varied eircles, snapping up on the wing the myriads of unlucky insects which they meet; but most wonderfully, most strikingly adapted for the life they lead are the menbers of the woodpecker tribe. One seeks them not on the smooth lawn, nor along the margin of pond and stream, nor in the blue vault of heaven above: for, as their name indicates, they are peckers of wood, and on trees, fences or wooden objects only, are they found. Darwin, in his epoch making book, "The Origin of Species," calls attention, time and again, to their marvelous adaptation of beak and tongue, of toes and tail. Couple with these a keen eye, a sharp ear and a long, strong wing, and we have the hardy denizen of the woods, who braves unflinchingly every clime and finds a plentiful living where other birds would quickly starre.

Of the five species of woodpeckers which spend the winter months with us there are two which are often confounded by the person who is beginning the study of birds. At a distance they appear to be colored exactly alike, both being black above with a white stripe running lengthwise down the back and numerons white spots arranged in crossbars on the quills of the wings. There is a narrow white stripe above the eye, and below it a broader and longer one extending beyond the eye, almost to the white stripe on the back. In the full girown male there is a crescent shaped scarlet band across the back of the head which is always lacking in the female. The under surface of the body is a uniform grayish-white.

In size alone are the two species readily separated; 
the larger or "hairy" being more than two inches longer than the "downy;" the average length of the former being nine inches from tip of bill to end of tail, while that of the latter is but six and a half inches. Only when we have them in hand do we detect any other difference than that of size. Then, by spreading out the tail, we find its outer feather's to be pure white in the "hairy," while in the "downy" they are cross-barred with black near the tip.

These birds were both first described by Linnæus, who gave to the larger one the name of Picus villosus and to the smaller one that of Picus pubescens. The word "Picus" means "woodpecker," while villosus and pubescens both mean "downy" or " eovered with very fine soft hairs." Later writers have divided up the genus Picus and have assigned certain of its members to other genera. Among these are the two speeies now in hand which, with a few others not occurring in Indiana, are placed in the genus Dryobates, which means "oak walker." The common names "hairy" and "downy," have evidently been derived from the specific names, and signify no difference whatever in the character of the plumage of the two birds.

The hairy woodpecker, Dryobates villosus (L.), has many loeal names in different parts of the country,

The Hairy Woodpecker. ehief among which are the "Virginia woodpecker," "big sapsucker," "big spotted woodpecker," and "big guinea woodpecker," the adjective "big" being prefixed to distinguish him from his smaller eousin which in eolor he so elosely resembles.

He is less sociable than the "downy," frequenting 
more often than that species the depths of the woods; though hunger often drives him in mid-winter to the outskirts of the eity, where, in the tops of the many decaying shade trees, he finds the struggle for existence between himself and his kin less deadly than in his native wood. A caleful cxamination of 82 stomachs

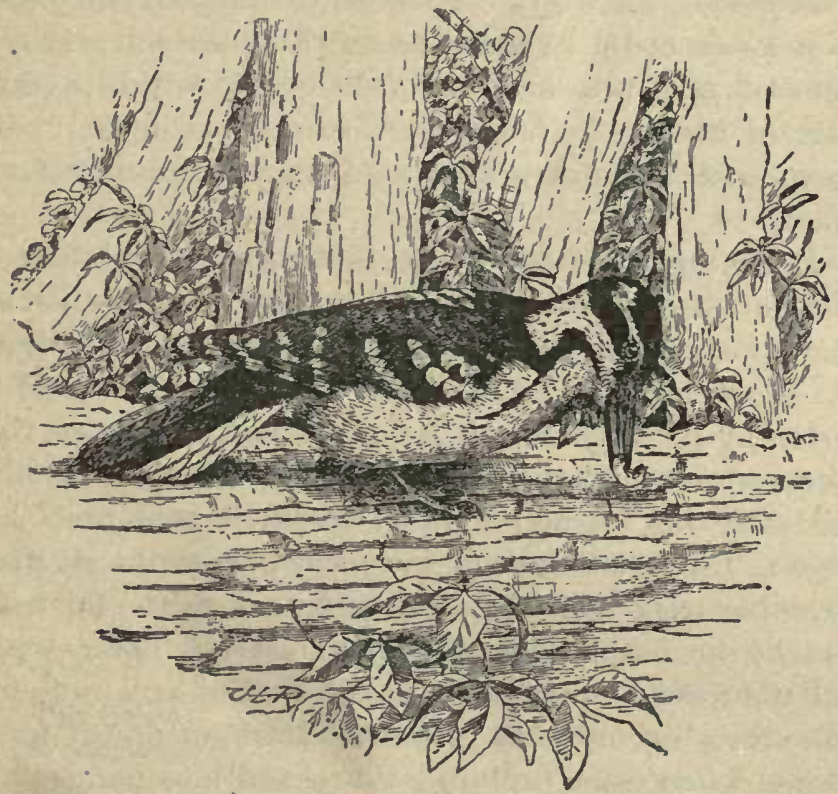

Fig. 7t-Hairy Woodpecker. (After Beal.)

of this species made by the Bureau of Ornithology at Washington, showed that 68 per cent. of the food was animal matter, largely the remains of injurious insects ; while 31 per cent. was of vegetable origin, consisting mainly of wild cherries, grapes and the berries of the dogwood and Virginia ereeper. 
On one bright December morning, I watehed, for a half hour or longer, a hairy woodpecker which had alighted near the middle of an upright limb of an oak. Instead of moring upwards, as is. his usual wont, he hopped backwaris an inch or two at a time for twenty or more feet, peering intently, on both sides as he descended, into every erevice and eranny in the bark. Not a sound did he make meanwhile, though a sausy ton-tit was ittering its "dee-dee-dee" within a few feet of his head and a zebra bird on an upper limb gave forth at intervals its loud alarm note of "charchar."

Reaching the base of the limb the "hairy" flew a foot or two to another and began to hop up this at the same rate of speed as he had descended the first. At short intervals he sounded the wood with his bill, listening intently the while, and at last, I suppose, the pereussion was satisfactory; for, fixing more firmly his stiff tail feathers against the tree as a prop, he rose to the full length of his short powerful legs, and drawing back his body, head and neck to the farthest extent, he dashed lis wedge-shaped bill home with all the force of his entire bodily weight and muscle. How the bits of lichen, bark and fragments of half rotten wood came tumbling down and how handsome lie looked with the scarlet cap on the back of his head, and the white central stripe contrasting so vividly with the glossy black of his back!

At last the reward came in the shape of a good fit grub which was quickly drawn from its hicling place ly the long barbed tongue of the bird. After swallowing this prize he was evidently well pleased with 
its taste for he uttered for the first time his usual call, "plick-plick," and then began once more his active search, peeking, pecking, hammering on his upward course.

-In this way his daily life is spent from November to March, often enduring ice, frost, snow, sleet, rain and hail, but cheerfully meeting them all undaunted. When the warm April sunshine enlivens the woods, and insect food can be had for the asking, he seeks for himself a mate, and together they excavate a nest in the terminal limb of a lofty beech or in the top of some tall oak snag. Here the eggs, five or six in number, are deposited. They are pure erystal white with an ivory texture and are $.85 \times .65$ of an inch in size.

\section{III.}

The "downy woodpecker," Dryobates pubescens (L.), appears to be much more plentiful than the "hairy," but this is doubtless due to his soeiable qualities as he seems to seek, rather than shun, the society of man. One does not so commonly find The Downy him in deep woodlands as in the
Woodpecker. orchards and the borders of woods near farm houses. Often, especially in the springtime, they are seen along roadsides, clinging to the upright stakes of the old worm fences, watching the plodding plonghman at his toil and scolding mildly if he comes too near. When the blasts blow cold, and the soggy limb of the forest tree is frozen hard, one may sometimes see a downy on the dead limb of a 
shade tree in the very heart of the city, where, though surrounded by a bedlam of noises, lie pecks away as industriously and contentedly as he does when in the depths of the forest. But they frequent the city much more seldom now than when that despised alien, the ubiquitous and aggressive English sparrow, was a stranger to our land.

The downy is known by several other common names; chief among which are the "little spotted

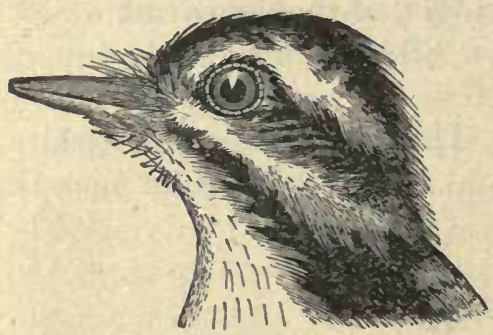
woodpecker," and the "little sapsucker." The latter name is, however, a misnomer, as neither he nor the hairy ever bore into trees for the purpose of gathering sap as does their Fig. 75-Head of Downy Woodpecker. cousin, the yellow-bellied woodpecker, Sphyrapicus varius (L.). The last named bird is a migrant, seen here only in spring and fall, and the holes he bores are small, shallow and close together, in regular circles about the tree; while. those marle by the downy and hairy in search of insect food are seattered irregularly over the surface of the limb or trunk.

On a recent October morn I watched a "downy" carving with his strong, chisel-shaped bill a cavity in a dead snag, probably one which he intended using as a winter shelter. Clinging to the edge of the hole, he would reach in until only his tail was visible, give three or four vigorous pecks, then draw forth his boly and head and "spit out," or rather cast aside the frag- 
ments of decayed wood he had broken loose. Glane: ing hurriedly about on all sides, he would again dodge in for a new series of blows. His feet remained in one place, but when at work his body was all motion; his tail, as he pecked, bobbing up and down against the wood, two or three inches below the opening of the hole. Thus he worked for twenty-eight minutes, when a slight movement of mine frightened him and he was up and away. The bottom of the eavity was five inches below the opening. Small feathers were found in it on several oceasions during the following winter, showing that it was used as a resting place, probably at night.

To the farmer and fruit raiser the downy woodpeeker is very valuable as an enemy of eaterpillars. It preys upon these insects in all stages. It drags the butterflies and moths from their hiding places; licks up by the score their deposited eggs; feasts for days in early summer upon the caterpillars themselves, and in autumn and winter bores neat round holes into the sides of the leathery cocoons and extracts the contents thereof. It is only when insect food beeomes very searce that it deigns to feed upon such dry forms of nutriment as grain, seeds of grasses and the softer nuts. From an examination of 140 of the stomachs of this bird it was found that 74 per cent. of the food was of animal origin.

The "downy" is sociable, not only with mankind, but also with his feathered kin in general. Especially in winter, does one often find him the leader or guide of a little coterie of chickadees, kinglets, nuthatches, and titmice-ramblers all, who go roaming in com- 
pany the livelong day. Their whistles and chirps, twitters and trills, uttered in unison, make a jubilee in January equal to any heard in June when the birds are supposed to be most numerous. I have listened manifold times to such a chorus and so have many other persons, particularly Dr. C. C. Abbott, who described as follows one he heard on a mid-winter morn with the mereury at zero: "The clear call of the erested tit opened the concert: The abundant chickadees twittered; kinglets trilled a merry roundelay; snow birds chirped; a cardinal performed an inimitable solo; and to all the downy woodpecker was alike attentive and drummed a tuneful accompaniment on the most resonant tree in all the woods."

\section{IV.}

In books we find portrayed the thoughts of manin nature, those of God. Tired of poring over the former I sought the woods and fields on the afternoon of a recent dim December day to study the latter, and, if possible, solve some problem, ever present, ever interesting, concerning the life history of beast or bird, of bug or bramble.

The blue sky of the forenoon had given way to a sombre gray which far and wide came down to meet the earth. No insect life was abroad on such a day. But if the insects were lacking, what of the birds? Had the leaden sky and north wind caused them, too, to seek a place of shelter and remain silent and invisible? As I asked the question the crr-rrh-rrh of a woodpecker in a neighboring beech denied the allega- 
tion; while the distant but rapidly nearing caw-caw of a flying crow lent strength to the denial. Woodpeckers and crows! No winter day too dull and dreary-no sky too leaden and cheerless-no north wind too harsh and biting, for them to be on the lookout for food!

To my surprise and delight I found the bird in the beech to be that handsome, tri-colored fellow known as the "red-headed woodpecker." This speeies which, it is said, first exeited the latent enthusiasm of that

The Red-headed Woodpecker. eminent naturalist, Alexander Wilson, and determined him to be an ornithologist, ranges over the whole of the eastern United States from the Atlantic to the Rocky Mountains. Its long seientific name is Melanerpes erythrocephalus (L.); melanerpes meaning "blaek creeper," and erythrocephalus, "red-headed."

The "red-head" is so different in color from all other woodpeckers that that one character alone will be sufficient to deseribe him for easy recognition. In adults, or full grown specimens of both sexes, the whole head and neck are a brilliant crimson; the under parts of the body, the shorter wing feathers or secondaries, and the rump are white; while the remainder of the body is a glossy blue-black. In the young the head and neck are grayish, or slightly tinged with red. The length from tip of bill, along the back, to end of longest tail featler is $8 \frac{1}{2}$ to $9 \frac{1}{2}$ inches.

The nest of the red-head is usually placed in a eavity which it excavates in a limb or trunk of tree at some distance from the ground; but often, for want 
of a better locality, it chips a hole in a fence stake, telegraph pole, church steeple, or cornice about the roof's of dwellings. The eggs are four to six in number,

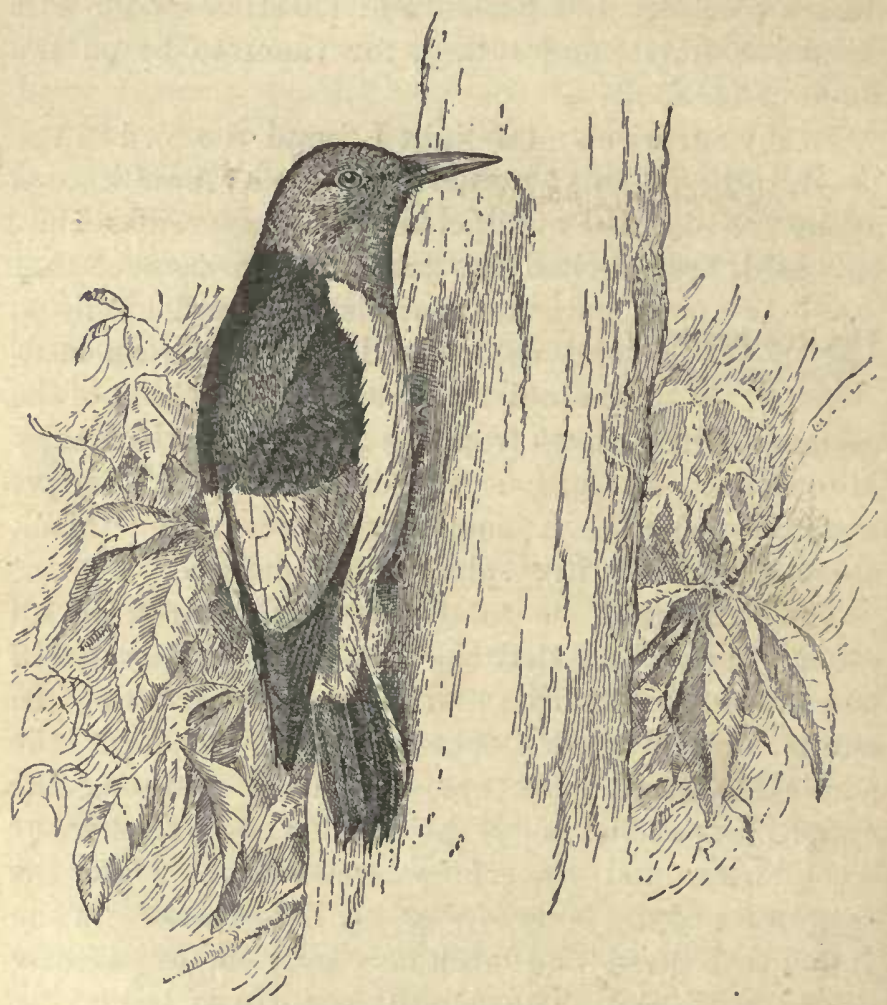

Fig. 76-Red-hoaded Woodpecker. (After Beal.)

elliptical in form, pure translucent white, and measure $1 \times 8$ inches.

In northern and central Indiana the red-head is usually a summer resident, arriving from the south 
about the middle of April and remaining until midOctober. During that time he is the most common species of the family, holding his own with perfect ease and ceaseless familiarity. In traveling through the country, during the spring and summer, one hears them sereaming in the adjoining woods, rattling on the dead limbs of trees, or on the fences, along which they are perpetually seen flitting from stake to stake on the roadside ahead.

In southern Indiana, and especially within the sheltered confines of the Wabash valley as far north as Terre Inute, the red-heal usually remains throughout the winter in small numbers. But in those seasons when beechnuts are plentiful he hoarts or stores up a supply of them for winter food and then remains in large numbers, even to the northern boundaries of the State. As soon as the nuts begin to ripen in autumn, the birds appear to be almost constantly on the wing, to and fro, from the beech trees to some place of deposit. They hide away the nuts in almost every conceivable situation. Many are placed in carities in partially decayed trees; and the felling of any old tree near a beceh grove is certain to disclose a pint or more of their chosen winter food. Another favorite storing place is beneath the loose bark of the hickory, or behind some long sliver of fence post or mil. Sometimes the muts are driven into the eracks at the end of railroad ties. Again they may be found in the erevices between the shingles on the roofs of barns or even houses. A friend, who is a close observer, also relates that the holes which are bored into the beans and logs of old cribs and sheds for the 
insertion of wooden pins, are often utilized as storehouses by the birds, being filled with beechnuts as fur as the red-head can reach. They oftentimes stuft the opening full of moss and eedar bark to hide the contents. Whether the bird remembers where each nut is placed, or whether it trusts to luck in finding it again is, as yet, an open question. That the red-head lives to a large extent in winter upon this stored food has been proven by the examination of the stomachs of a number of specimens at that season.

The belief, so common among many persons, that these birds are weather prophets, and, foreseeing a long hard winter, depart early in autumn for a warmer clime, is, in my opinion, unfounded. Irregularity of migration, residence, and so forth, among birds, is, I believe, due almost wholly to irregularity of a suitable food supply.

But our red-head, as he has advanced in civilization, has developed a taste for other articles of food besides nuts and insects, and has become, in the words of Maurice Thompson, "a cider taster, a judge of good fruits, a connoisseur of eorn, wheat and melons, and an expert thy catcher as well." IIe is excessively fond of ripe mulberries and wild cherries, and in their season spends much time in winging his way to and from these trees. I have often seen him dart from the top of a mulberry or other tree, and with unerring flight catch upon the wing some unlucky insect, and then immediately return to his diet of fruit once more.

During the summer months he chooses the finest cherries, grapes and apples for his dessert and thus 
oftentimes brings upon himself the unqualified rage of the farmer or fruit grower. When Indian corn is in its rich, succulent, nilky state he attacks it with great eagerness, opening a passage through the numerous folds of the husk, and feeding on it with voracity. But for every cherry, apple or ear of eorn thus destroyed, a thousand injurious insects are annually eaten; and so the farmer when he tells his boys "to show no mercy to the red-heads in the orchard" is only "saving at the spigot to lose later on at the bung."

Professor Forbes of the Illinois University examined the stomachs of a number of these birds during the month of May and found that their food at that season eonsiated of: eanker-worms, 15 per cent.; beetles and other injurious insects, 65 per cent.; seeds and grain, 20 per cent.; thus proving their value as insect destroyers. In 101 stomachs examined at Washington, 50 per cent. of the food was of animal, 47 per cent. of vegetable, and the remainder of mineral origin. Beetles and grasshoppers formed 36 per cent. of all the food, while the regetable portion was mainly wild fruits, though 17 of the stomachs contained corn.

The red-head is ever ready to pick a quarrel, not only among members of his own species, but frequently with other birds, and their noisy chatter when thus engaged too often makes a bedlam of our fairest woodlands and drowns ont the pleasing notes of the more favored songsters. 


\section{V.}

'Twas the day before Christmas-bright and beantiful-a winter day in name only. As I tramped towards the boundaries of one of nature's domains, far beyond the city limits,
A balmy thermal breeze
To me,
From sunny, southern seas
Came joyously.
$A h$, rare the day
At Christmas tide,
When on such breeze
One's thoughts can ride.

Reaching the border of a thicket enclosed by an old worm fence, I seated myself on the topmost rail of one of its panels and waited for sound or sight of animal life. I had not long to wait; for soon the ehatter of a noisy jay came from the top of a near-by oak, while a erow in the midst of the thicket began to challenge me with his limited voeabulary of " hah-hah, hah-hah." His call was inmediately answered by one of his brethren in a neighloring woods-this one by still another farther away, and thus a series of signals traveled across the township-a wave of erow laughter, as it were-of which I, perhaps, was the involuntary cause.

Suddenly another sonnd broke upon my ear, a clear, ringing, highly musical note-“willy-vay, willy-vay, willy-way,"-repeated at short intervals. It resembled somewhat the whistle of the eardinal grosbeak, or "rea bird," but was a far louder and more pleasing 
eall: I was thrilled with delight, for I reeognized instantly the spring note of an old aequaintanee, the

The Great great Carolina wren. Few, indeed, Carolina Wren: are the 'winter days when this, the charaeteristie, vernal love call is uttered; but the "sunny, southern" breeze had brought joy also to the wren's heart, and forgetful of season-. forgetful of the many eold, dreary days which must intervene before the call could be rightfully issuedconscions only of the warm and soothing sunshine, the singer made the welkin ring for rods around.

The wren was not visible, and was much farther away than I thought, when I started toward the seeming souree of the song. The resonant quality of its note caused, as it were, the whole copse to ring with the sound, th us deadening, to a certain extent, the direction from whenee it came.

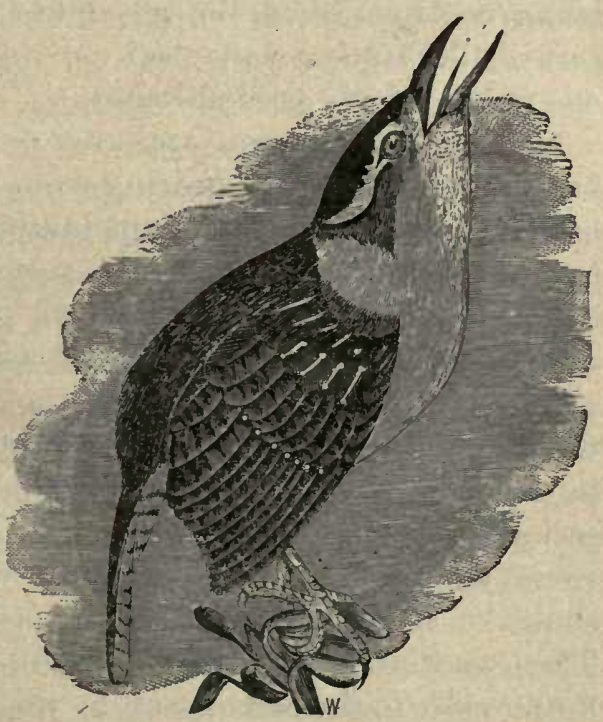

Fig. 77-Great Carolina Wren. (After Coues.)

After some ten minutes' seareh, during which the notes were stopped a number of times and then re- 
sumed, I espied the songster sitting atilt of a splinter which extended upward from the center of the stump of a fieshly ent tree. His tail was bent downwarl, his head raised heavenward, while the rich rolling notes were issuing forth with a force and energy seemingly wholly at variance with the size of the bird.

Unfortmuately he saw me too, and instantly the call was hushed, and with a headlong dive he went into the depths of an adjacent brush heap. I stepped behind a tree and waited, for the Carolina wren shares the restlessness and prying euriosity of all his tribe, being continually on the go-fidgety-all starts and jerks-like some people we know in whom the nervous tissue largely predominates.

Sure enough he soon appeared on the side of the brush pile nearest ne, peering from among the deal leaves with an inquisitive air, jumping from twig to twig of the brush-all the time teetering his body in a peculiar wrennish fashion, and performing other odd, nervous antics as if possessed with the very spirit of unrest. Finally he reached the topmost twig of the pile of brush from which commanding situation he resented my intiusion upon his domain with a series of scolds-prr-prr-prr-for twenty or more times, emphasizing each utterance with a quivering shake of his whole body and especially of his tail. Then another dive into the brush-a flitter and a flutter close to the earth-and he was hopping beneath a fallen beech which, a few rods away, was supported on its branches some feet above the ground. There let us leave him for a short time while we make known 
some of the more important facts concerning his life history.

The great Carolina wren is "great" only in comparison with other wrens, being the largest of six species which occup in Indiana, and the only one which spends the entire year with us. Another, the little winter wren, nests in northern regions and spends the cold season from the latitude of central Indiana, southward. The other four are "summer" residents," nesting in the State and going south in antumn. All are plainly colored, being chiefly brown ; and all, in the words of that eminent ornithologist, Elliot-Coues, are: "Sprightly, fearless, and impudent little ereatures, apt to show bad temper when they fancy themselves aggrieved by cats or people, or anything else that is big or umpleasant to them. They quarrel a good deal and are particularly spiteful towards martins and swallows whose homes they often invade and occupy. Their song is bright and hearty and they. are foud of their own music, but when disturbed at it they make a great ado with noisy scolding."

The bill of the Carolina wren is stouter than that of the other species, and its front half is somewhat decurved or bent downwards. The total length of the bird is $5 \frac{1}{2}$ to 6 inches, the tail being a little shorter than the wings. In color it is clear reddish-brown above, brightest on the rump, and with the feathers of the wings and tail finely and prettily barred with blackish. Below it is a tawny yellow. The throat and cheeks are gray, while a narrow whitish line curves backward over the eye, and a bar of small white spots crosses the wings near their base. 
Other common names by which it is known are "mocking wren" and "large wood wren," while its long Latin name is Thryothorus ludovicianus (Gmelin), the first part of which is derived from two Greek words meaning "reed" and "leaping," while the last or speeific name is the Latin for "of Louisiana," from which region the bird was first described.

Its chosen haunts are the wooded or rocky banks of streams, piles of logs and brush heaps in clearings, or the zigzag lines of the old rail fences with their corners full of bushy shrubs and fallen weeds; indeed, wherever nature, accident, or design has provided a place where it can make itself conspicuous one instant and be entirely concealed the next. There, too, hidden beneath lichens, in the depths of fungi, or in the cracks and crannies of rail or $\log$, its favorite food, spiders, ants and gnats abound. Its thick-set, bulky body, short wings and tail, and slender, slightly curved bill, are especially adapted to an insectivorous life close to the ground. The wren, therefore, is seldom if ever seen in the tops of tall trees, but sometimes ascends their trunks for quite a distance, peering beneath every piece of loose bark and entering every knothole through which it can squeeze its body, in search of its esteemed spider diet.

The nest of this bird is a bulky structure, composed of strips of bark and corn stalks, grasses, leaves and fibrous roots, and usually lined with feathers, corn silk, or horse hairs. It is placed in any odd nook or cranny that its owner fancies, such as the cavity of a $\log$ or stump, the augle of a fence between the lower rails, in a pile of logs or brush-anywhere, in fact, that 
offers a snug retreat. Often it is arched over at the top, the entrance being at one side and only large enough to admit the builder. The eggs are five to seven in number, reddish-white, thickly spotted with vacious shades of brown, and measure $.73 \times .60$ of an inch. There are two, sometimes three, broods each season, but many of the young fall a prey to carnivorous snakes, weasels and small owls.

In winter the sexes separate; each pre-empts for itself a certain territory as a forage field, and woe betide any feathered form of moderate size which ventures upon its chosen domain. As Dr. Abbott has well said: "The tenants of the wild woods know the wrens full well and usually give them a wide berth. They realize that they are petty tyrants, suffering no intrusion and excusing no blunders; partieularly so when something has gone wrong with them; then it is a word and a blow, and the blow first. Even the hornets stand back when there is a riot in wrendom."

Thus the winter days of our wren are spent in spider hunting, fighting and singing; for besides the spring call and scolding chirps mentioned above, he has many other notes, some of which are as varied and pleasing as those of the brown thrush. The nights are passed in hollow rail or limb of tree, and when the face of earth is clad in snow and ice probably the major part of many a day is spent there too, in fasting and musing-if a bird can muse-o'er the victories won in the past and the battles to be fought in the future.

$$
* * *
$$

Wishing to reward the one I had seen with a 
Christmas repast, I turned over a large log, on the under side of which were a colony of ants and a number of fine fat grubs; then, slipping around the fallen beech under whose limbs he had dodged, I started him towards the uncovered feast. After some masenvering he reached the log, espied the menn-and then, how he fed! Turkey, mince pie, cranberry sance, and all, those grubs and ants were to him, and thus, in part, I paid him back for his morning song.

\section{VI.}

The subject of the present sketch, the winter wren, is one of the smallest, and to my mind one of the most interesting of the fifty or more species which pass the cold season in this latitude. The diminutive size of the bird, its quick motions, and especially its brown color, resembling so closely that of the dead leaves and grass among which it flits, canse it to

\section{The} The remain unseen, unsuspected, and often
Winter Wren. quite unknown to the ordinary rambler
in the woods. Even the naturalist, with trained eye and ear ever open to listen to nature's sounds, counts that day a fortunate one when he catches a glimpse of the little creature as it hops or flits close to the ground, in and out of a fence corner, or from side to side of a brush pile or log heap. For it possesses the wrennish peculiarity of being ever on the go, and although it rarely uses its wings except for a short flutter from one bush or angle of fence to another, yet it hops slyly and rapidly abont, appearing perhaps for an instant, then suddenly lost to view. 
When thus engaged in active search for insect life, and I never saw one of them otherwise, its bit of a tail is somewhat spread out and raised almost perpendicularly over the back; the neck is bent forward and the straight bill stuck out ahead; thus giving the little bird a most determined and inquisitive air.

The length of the winter wren is not over four inches from point of bill to tip of tail. The bill is very straight, slender and conical. The tail is shorter than the wings, which reach to its middle. In color the body is deep reddish-brown above; the brown being everywhere, except on head and middle of back, transversely barred with dusky. Below it is pale reddish brown, sharply barred on the posterior half with dusky. A line over the eye, some obseure streaks on the sides of head and neck, and some bars on the outer wing feathers are whitish.

Other common names, besides "winter wren," are "bunty wren" and "little $\log$ wren," while the long Latin name is Troglodytes hiemalis Vieillot, the first part of which means "cave dweller" and the last "wintry."

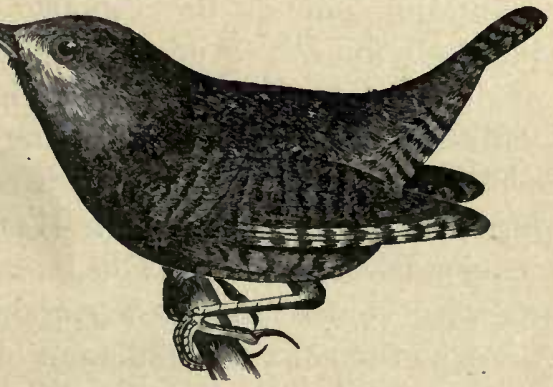

Fig. 78-Winter Wren. (After Coues.)

Within the past five years I have seen twenty or more speeimens of this little wren between the months of October and April, yet I lave never heard one of 
them utter other sound than an occasional ehuckle like the syllables "puiq-quap," or a low wren-like chirr, when startled or firightened. They are most common in Indiana during the spring and fall migrations, as large numbers of them spend the winter farther sonthward, and must, therefore, pass through this region on the way to and from their summer homes. They nest in the pine forests of Wisconsin, Michigan and British America, especially in damp, swampy regions, where the ground is covered with fallen trees and logs, piled upon one another and covered with rich moss.

In such a place the male is said to sing most exqui- sitely, one author describing its song as: "Very lively and hurried, the notes seeming to tumble over one another in the energy with which they are poured out. They are full of power, though many are shrill, and are garnished with many a gay trill; in some passages reminding one of the Canary bird's song, though infinitely finer." Audubon, that prince of American ornithologists, appears also to have been enchanted with the song as the following words will testify: "The song of the little winter wren excels that of any bird of its size with which I am acquainted. It is truly musieal, full of cadence, energetic and melodious; its very continuance is surprising, and dull indeed must be the ear that thrills not on hearing it."

The nest is placed in cavities about the roots of stumps or in the tangled piles of fallen trees and branches. It is eomposed of small twigs interwoven with moss and lichens and lined with the feathers of other birds or with rabbit hair which the bird has 
picked up in the vieinity of its home. The eggs are five or six in number, pure crystal white, spotted with bright reddish-brown, and measure $.67 \times .48$ of an inch.

During the winter, while the woodpeckers, nuthatches, titmice and chickadees are fast lessening the hordes of insects which inhabit the trunks and limbs of trees, the wrens are doing the same good work among the $\log s$ and stumps close to the ground. There they have less competition, and so find the struggle for existence less deadly than they would higher up among their larger arboreal kin. Thus, in the course of time, each form of bird has found for itself that place in the realm of nature best suited to its existence; and there, most often; do we find it, ever on the search for its favorite food and ever on the alert to prevent itself being eaten by some animal higher in the scale of life.

\section{VII.}

The avian or bird fauna of Indiana has been modified in many respects by the presence of the white man and his progressive civilization. The Carolina paroquet and ivory-billed woodpecker, onee frequent in our forests, have receded before his advance, and, like the Indian, buffalo, bear, elk and deer, are gone forever. Only in the densely wooded districts of the sonthern and south-western States do these two noble birds still exist. Even there their numbers are constantly lessening, and, in the opinion of the best judges, a quarter of a century hence they will be known only 
in museums and in-literature. The pileated woodpecker or log-eock, once abmindant and second only to the ivory-bill in size and beauty, is also nearly extinct in this State, ocenring in small numbers only in, the densely wooded portions of the sonthern connties. Wild pigeons, formerly so numerous that flocks of them were visible in the air for hours at a time, are no longer seen; while wild turkeys, once the source of many a day's exciting sport, have almost wholly disappeared. Many species of hawks and owls are beconing scarce on acconnt of the unmitigated and senseless warfare waged against them by persons wholly ignorant of the good these birds do in preying upon the hordes of smaller manmals and larger injurious insects.

On the other hand, that well known bird, the quail or bob-white, was probably absent or confined to but few localities in the State at the time of its first settlement, and has steadily increased in numbers as the forest has been cleared away. The lark-finch, a handsome member of the sparrow tribe, has made its way in from the plains and prairies of the west and has spread eastward as far as the Alleghanies. Its congener, the dick-cissel or black-throated bunting-onee rare-now rolls forth at June time its characteristic warble from the borders of every clover or grain field in the State; while that pestiferous alien, the English sparrow, an enforced immigrant from good Great Britain, has multiplied by countless thousands within the past decade.

Many other instances of decrease or increase in the number of birds, caused either directly or indirectly 
by the settlement of the country, could be given, but let us now note a few of the changes in habits which our native birds have adopted since the white man cameand so lead up to one discovery in particular which the shrikes or buteher birds have made and put to use.

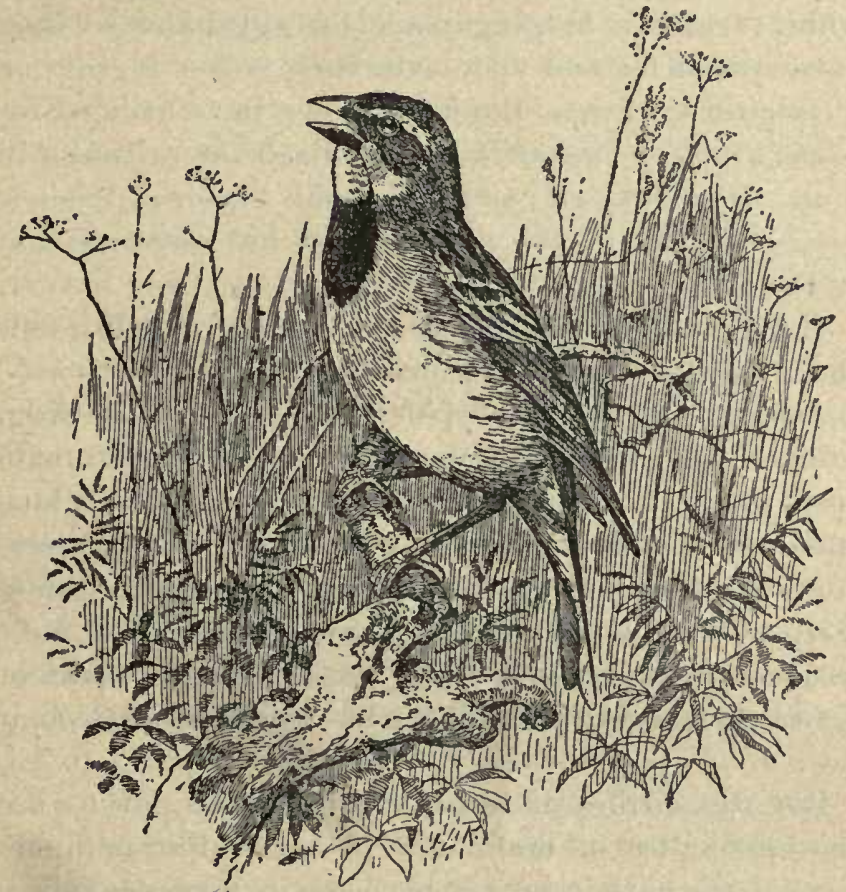

Fig. 79-Dick-cissel or Black-throated Bunting. (After Judd.)

The chimney swifts, before the advent of eivilized man, nested and roosted in hollow trees, but these trees becoming scarce and ehimneys frequent, and possibly more to their liking, they in time forsook, almost wholly, the former for the latter. 
Woodpeckers, before the settlement of the prairies, were confined to forest areas on aceount of a lack of suitable nesting places; but they have discovered that the cornices of buildings, church steeples, telegraph poles and even rotten fence posts, will, with a little labor, furnish a lodging place for eggs, and so they have spread far and wide over the treeless regions of the westeru States. Bank swallows have utilized for nesting places the artificial roadbeds of railways in some of the flatter counties of the State, and hence their presence in such regions does not antedate that of the "iron horse."

Many rapacious birds, as the smaller hawks, owls and kingfishers, since the clearing away of the forests, use the top of telegraph poles as resting places firom whence they can swoop down upon such unfortunate prey as may come within their vision; while blue birds and swallows, in lieu of a better resting place, often line themselves along the wire and twitter and chirp to one another, wholly unconscious of that electric foree which is propelling the thoughts of man at lightning speed along the slender thread beneath their feet.

But the shrikes or butcher birds have put to use another device of man, and in a peculiar manner: namely, the barbs upon the barbed wire fences as spikes upon which to impale their prey. For the shrikes are the bushwhackers among birds. No others are so notorious for cruelty and rapacity. Not only for food, but apparently for the gratification of a blood-thirsty instinet, they kill forms of life beneath them merely as a means of killing time. They alone of all birds 
impale their victims upon sharp pointed projections. 'Their food consists of mice, small birds, snakes, beetles and grasshoppers. Formerly these birds visited only low-ground thickets where crab-apple, haw-thorn and honey-locust or "thorn-trees" abounded, upon whose sharp twigs and thorns they hung their victims. But since the advent of the barbed wire fences the shrikes have appeared everywhere along upland fields, finding in the sharp, stift barbs just the kind of an impaling spike they wish. Why the prey is thus hung on thorn or barb has not, as yet, been satisfactorily explained, for it seems that objects so impaled are afterwards seldom touched by the bird.

Two species of shrikes inhabit Indiana. One, the logger-head shrike, Lanius ludovicianus L., is a summer resident, arriving from the south about April 1st and departing thither about mid-October. This is the species which impales so many grasshoppers and beetles along the wire fences during the summer and autumn. On one October day I gathered fully a pint of such impaled insects from a fence row half a mile long, and found that they represented sixteen species; eight of grasshoppers, two of katydids, and six of beetles, all injurious, so that this bird, althongh savage and bloodthirsty, is of great benefit to the farmer and fruit grower.

No sooner has the logger-head departed for the south, than its cousin, the great northern sirike,

The Great arrives from the north to spend the Northern Shrike. winter with us. In general appearance this latter species closely resenbles that exquisite singer, the southern mocking bird; 
but the shrike is readily distinguished by its more bulky form and its much stronger hooked and notehed bill. In size it is about the same as the conmon robin, measuring $9 \frac{1}{2}$ inches from tip of bill to end of tail. Above, the general color is a clear bluish ash, somewhat paler on the rump. Below, it is a dirty white, everywhere erossed with fine, wavy blackish lines. The quills of wing and tail and a broad bar along the side of head are black; while a white spot is situated upon the lower half of each wing.

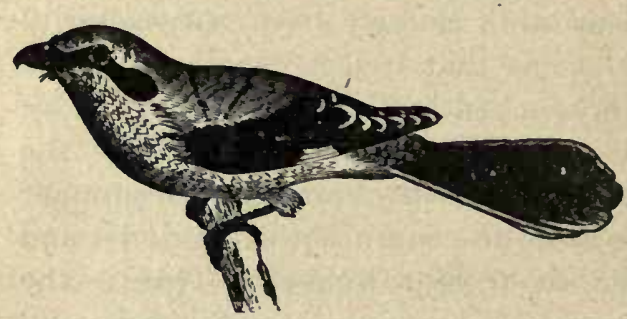

Fig. 80-Great Northern Shrike. (After Coues.)

The northern slırike nests ouly in British America, but in winter ranges southward to about latitude 36 degrees. Its scientific name is Lanius borealis Vieillot, from two Latin words meaning "butcher" and "of the north." During severe winters these birds often appear about the suburbs of cities and prey upon the English sparrows, and sometimes become so bold as to fly into open windows and attack a canary, even in the presence of human beings. By the Germans they are often called neuntödter or "nine killers," from the belief that they eateh and hang up nine mice or nine sparrows each day.

They are treacherous birds and use many devices to get within striking distance of their prey. Dr. Abbott has well described their actions as follows: "I remem- 
ber one, demure as a scheming crow, with eyes half shut and with not a trace of treachery or cunning in his face. His blue and white pluniage, tastefully trimmed with black, made him conspicnous, but he lessened the ill effects of this by the manner he assumed. No bird, however timid, would step aside for such as he. Indeed, they perched upon the same branch of the tree he was on, almost upon the same twig, andwhere was he?

"Like a flash the shrike had disappeared, and now, fifty paces distant, he is perched upon another tree, plucking feathers from a kinglet's head and regaling limself with his victim's brains."

Shrikes seldom sing. On a sunuy December day, I was, however, favored by the song of a butcher birl. I was on the lookont for him for I had found a sharp-nosed shrew-mouse hanging on a barbed wire fence, and knew that a shrike had its winter quarters in the immediate vicinity. Suddenly a bull-headed bird, with chops muftled in black, sprang from a fallen thorn tree to a wild cherry in a near-by corner of the rail fence, and I knew that the butcher was in ny presence. Eyeing me furtively for some tme he jumped from branch to branch towards the top until finally he reached the uppermost twig when suddenly he uttered four sharp notes. They were nutuch like the warning ery of a cock when he discovers a hawk or large bird in the air-"err-crr-crr-crr." Then, after an interval of a few seconds, he began a song which was continued for at least five minutes. It was uttered in a joyful manner but at the most was a monotonous ditty, a "puit-tuit-toot-e-ree, puit," etc. 
During the singing he gazed attentively at me as if sceking to note the effect of his musie, taking no notice of the wrens and sparrows which were flitting about in the fallen thorn. As I stepped towards the tree on which he was perched he uttered a harsh note, a shriek of protest, as it were, at my intrusion; then giving two or three vigorous strokes with the wings, he folded these organs close against liis. body, and, with a peculiar gliding motion, passed swiftly into a bushy oak shrub a hundred yards away.

\section{VIII.}

The student of nature soon learns to notice the interdependence existing among all forms of living objects. All animals are wholly dependent upon plants for their existence, for plauts alone can change inorganie matter-earth, air and water-into stareh, sugar and other organic food-stuft's for animals. Plants alone ean collect and store up in these foods the radiant energy of the sun's lieat and light, and so transmit it to the animals within whose bodies it is changed into animal force and used as nervous, museular and gland power to perform the duties of animal life.

On the other hand plants receive many benefits from animals. Insects carry the pollen from flower to flower and so aid in the fertilization and cross fertilization of the plants. To bring about the visitation of insects to the reproductive parts or anthers on which the pollen is produced, the plants have developed honey secreting glands about the base of the anthers 
and then surrounded them by showy petals so that the inseets may readily find their way to the honey and in their search for it uneonscionsly scatter the pollen. In this way all the showy parts of flowers have originated.

Again, birds and plants are mutually dependent, the birds feeding upon the fruits of the plants and in turn seattering or distributing the indigestible seeds far and wide over the face of the earth. Indeed, all the fleshy parts of fruits have in time been developed around the seeds for the sole purpose of bringing about the distribution of the latter. Man gathers apples, oranges, or apricots from the tree for the sake of the flesh or pilp, not for the seeds; but in getting the pulp he carries the seed far away from the parent tree. Cherries, raspberries, strawberries and many of the fruits of wild plants are very attractive to the palate of birds, and the latter are therefore the chief agents in the distribution of these fruit producing plants.

Anong our frugivorous birds the cedar bird or cherry bird lanks pre-eminent for the great variety of wild fruits which it. eats. This bird is a permanent resident in Indiana, but is most almundant during the spring and fall migrations as many of them spend the winter farther southward. It is almost always seen in flocks, usually from forty to a hundred together. It has no song and no gaudy colors, yet from the

The delicacy and softness of its plumage it Cedar Bird. is one of our most beautiful birds ; and during the craze for feather ornamentation, which was so prevalent a few years ago, and 
which still exists among certain stages of society, the cedar bird was one of the most common species seen on women's hats.

In length it measures about seven inches from point of bill to tip of tail. Above, the general color is a cinnamon-brown, paling to slaty ash on the wings and

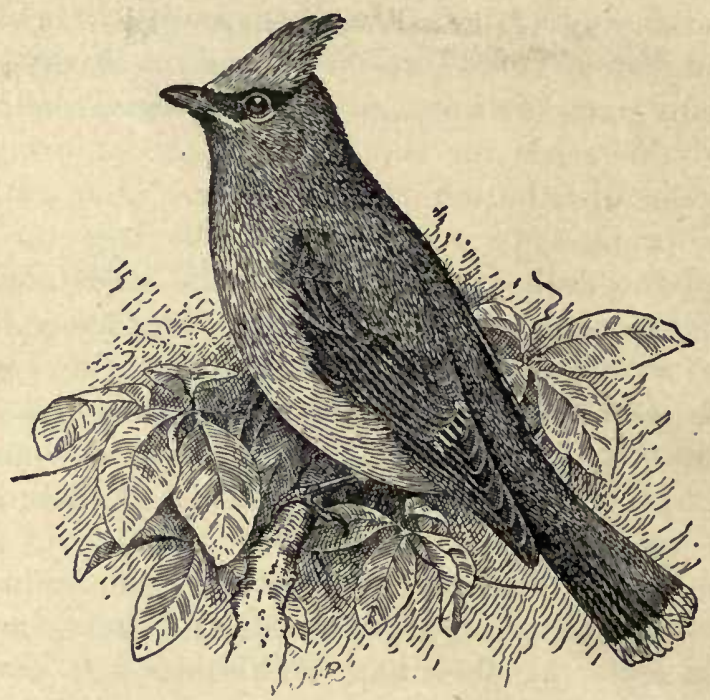

Fig. 81-Cedar Bird. (After Beal.)

tail, the feathers of the latter being tipped with a band of yellow. A broad stripe of black passes from the nostrils back along the side of the head, and the chin and forehead are also black. The tips of some of the wing feathers, and sometimes also of the tail feathers, bear little oval, flat, leaf-like appendages which resemble red sealing wax; while the head is ornamented 
with a conspicuous erest which can be raised or lowered at pleasure.

The wax-like tips on the wing feathers are only prolongations of the shafts with suriously formed pigment cells containing an abundance of red and yellow coloring matter. Their presence gives rise to two common names, other than those given above, by which the bird is known, namely: cedar wax-wing and Carolina wax-wing. The seientific name is Ampelis cedrorum (Vieillot), meaning "fruit eater," and "of the eedars;" as one of the favorite foods of the bird is the cedar or juniper berries so common in some localities.

The cedar bird, like many human beings, lives to eat. Althongh an abundant speeies throughout the State it is so eapricious in its movements that its presence or absence in a eertain locality appears to bear no relation to season or weather, the question of food supply alone being probably the controlling influence in its wanderings. It feeds on cherries, both wild and cultivated-whence its name, "cherry bird"-on the berries of the sour gum, dogwood, bitter-sweet and pokeweed, and will often so gorge itself with these as to be almost unable to fly. Whenever a flock alights in a tree bearing their chosen food they sit for a time motionless and ereet like parrots; then, by a movement of the head, each one takes a survey of his immediate surroundings, after which, one by one, they proceed to the ehief business of their lives.

In spring and summer, before the ripening of the fruit and berries, this bird is of great benefit to the farmer, as it then devotes itself almost entirely to 
catching insects. It is an expert fly catcher, and may often be seen perched upon a dead twig near the top of some tall tree from which it makes its graceful and successful flights after the different insects passing near. In this way it repays more than twenty fold for the cherries it later on devours.

The cedal birds are noted for their extreme sociability and even fondness for their kind. They are anong the few birds which appear to be permanently gregarious, i. e., always found in flocks. They build their nests very late in the season, sometimes not till the middle of July, and are seen in flocks up to that time. Several nests are often constructed in the same tree and usually all those of the same flock are built within the compass of a few rods. The nest is a bulky structure composed of many materials, such as bark, roots, twigs, paper, rags and twine, and lined with the finer grasses, hair and wool. The eggs are three to six in number and are slate brown marked with many purple or dark brown blotches.

The sociability of these birds is kept up during the five or six weeks that they are held in one locality by the care of their young and when the latter are ready to leave the nest they remain with their parents.

On a recent January morn my attention was attracted to a flock of birds which was continually flying from some trees to the margin of a small pond and back again. I moved slowly towards them and found them to be cedar birds which were feeding upon the fruit of the hackberry, Celtis occidentalis L. They were working rapidly and tearing at the berries so eagerly that as many fell to the ground as were eaten. 
About cvery five minutes a dozen or more members of the flock would sweep in an easy and undulating but swift flight to the margin of the pond and after drinking would fly again to their feast. They made no sound except an occasional lisping tsip in a low tone. Occasionally one would be overcome with curiosity and would fly to the branch of the neighboring tree under which I stood and peer down at me, moving his head from side to side while his eyes seemed to sparkle with excitenent; then back he would go again, showing as he flew the waxen tips on his primaries and the bright yellow border on his tail feathers.

I envied them their food, plucked from the tree on which it grew, and therefore free from adulteration of any kind; sweet, resembling a black haw in taste; the only drawback being that the pulp or nutritious part is very small in proportion to the bulk of the seed. But the former is sufficient in quality and quantity to attract the birds and therefore serve the purpose of the hackberry; and perhaps many a Celtis will owe its future existence to the visitation of the Hock of cedar birks seen by me; the seed being dropped in some distant plaee where its chances for life and growth will be a thousand fold greater than if it had fallen to the earth beneath the parent tree.

\section{IX.}

Many of the natural haunts of our winter birds, which formerly existed within easy reach of the eity, have disappeared. As a consequence the birds themselves are yearly becoming less frequent in number. 
I have in mind a wooded tract, of probably 100 acres, which a few years ago was thickly grown up to under-brush and contained many fallen trees. There, on any day in winter, one could find twenty or more species of birds, on the trees, in the brush piles, or on the ground, each one seeking its food according to its adaptations. Not only birds but many other forms

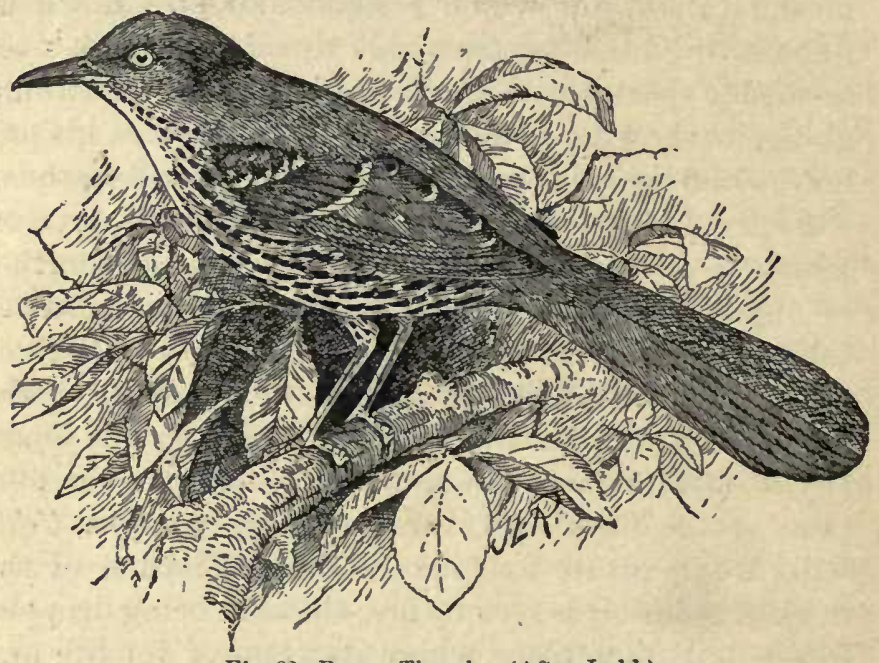

Fig. 82-Brown Thrush. (After Judd.)

of living things, such as snails, reptiles, batrachians, and insects of varied size and shape, found a congenial home within the borders of those woods. But, although they belong to a wealthy family who could well afford to have spared them, to-day all is changed.

Every brush pile where in summer nested the brown thrush and Carolina wren; every $\log$ beneath which the plodding snail, spotted salamander or white- 
footed mouse found shelter; every shrub and weed on whose leaves and flowers beetles and butterflies of brilliant hue had been wont to feed, are cleared away. The broad and level sward with its unbroken carpet of Kentucky blue-grass no doubt presents an attractive appearance to the eyes of the rich owner; but the tenants of yore, which to him were unknown or despised, though some of them for many years had been his helpful friends-what of them?

To my mind they were the rightful owners of the land. Back in preglacial times, before the overflow from a giant, melting, bulk of ice had carved out the broad valley to the westward-back then, and even before-the first inseets, birds and marnmals "entered" this tract of land and began on it a struggle for existence. There, for year on year and century on century, has this struggle continued, and though the home and happiness of many of the contestants were destroyed by the elearing up of the under-brush, yet it still continnes. Nor will it wholly end until the advancing eity will have encroached upon the bounds of this domain of nature, and then man, prond, artificial, unnatural, will forever drive out the rightful denizens and prove himself the fittest in the struggle.

The above is but one example of a thousand going on everywhere about us. To produce that which will bring him wealth-although his coffers may be fill to overflowing-man willingly and thoughtlessly causes the death or disappearance of manifold forms of living things and creates sad havoe with the true beauty of nature's own. Like Thorean, I exclaim: "Thank God, he can not cut down the clouds." 
Among our winter birds none was formerly more familiar than the so-called "snow-bird" or slate colored junco. It arrives from the north about October the 15th and its coming is always a precursor of the winter that is to be. During the pleasant weather, when the earth is bare, it seeks the shelter of such wildwood tangles as the one above mentioned. There, The Snow-bird. $\begin{aligned} & \text { seattered among the leaves and on the } \\ & \text { dead stems of low grasses and weeds, }\end{aligned}$ it finds its favorite food, the seeds of wild plants, which it oecasionally varies with such small beetles or grubs as it may happen upon. But when such food is hidden beneath a coating of ice and snow the junco has to retreat from its thicket stronghold and then it comes trooping about the dooryards and barnyards of man, ever ready to pick up those "crumbs of comfort" which are dropped intentionally or otherwise in such places.

The snow-bird belongs to the great family of Fringillidoe which comprises the sparrows and tinches, 38 of which are known to oceur in Indiana, 17 of them being found here in winter. The chict character which distinguishes this family is a thick cone-shaped bill which is shorter than the head and abruptly angulated or drawn down at the corners of the mouth. Witl this they can crush the hard outer shell of most of the smaller seeds and feed upon the rich, nutritious kernels within. The English sparrow and Canary bird are two familiar nembers of the family.

Although seeds form the main diet of all these birds, yet, in early spring and summer when seeds are scarce, they turn to insect life to furnish them sustenance; 
and Prof. S. A. Forbes found that 91 per eent. of the food of 47 sparrows which he killed in an orchard in May, was composed of insects; four per cent. being canker worms, which are so injurious to the foliage of the apple tree. Moreover, the young of the 17 species which nest in the State are fed wholly upon insect food, so that, all in all, the family is a most beneficial on e to our husbandmen.

In size the snow-bird is below the medium, measuring but $6 \frac{1}{4}$ inches in length. In color it is a uniform ashy or blackish gray above, somewhat darker on the head. Below, all back of the breast is pure white, as

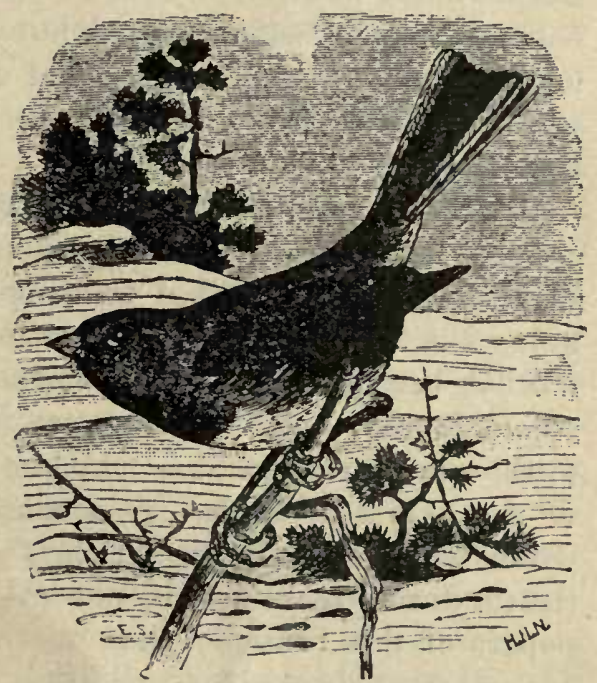

Fig. 83-Snow-bird. (After Coues.) are also the two or three outer feathers of the tail. These feathers are ever a sign of its identity, for as it flies it spreads its tail enough to show their edges. No other bird of similar size possesses them except the grass-fineh or vesper sparrow, which is everywhere streaked, both above and below, with reddish-brown and dusky. 
From the above description it will be seen that the name "snow-bird," by which this sparrow is so commonly known, is a misnomer as far as eolor is concerned, and was probably given to it on aceolint of its habit of flocking about houses and barns after every snow storm.

Its scientific name is Jinco hiemalis (L.), from two Latin words meaning "a rush" and "wintry.". The eommon name, "slate-colored juneo," which, among naturalists, is coming into gencral use, is sufficient to properly distinguish it from other members of the same genus.

While the snow-bird is known to every one in the country as a common and familiar winter resident, there are few people but to whom its coming and going is a mystery, and the question is often asked: "What becomes of the snow-birds in summer, and where do they nest?" Many are the answers given to this question by persons who know little or nothing of the habits of lirds. A common belief, and one which was upheld by an article which appeared less than a dozen years ago in one of the leading newspapers of this State, is, that our common sparrows, such as the field sparrow and grass-finch, change color in fall, becoming snow-birds, which they remain until spring, when they don their other dress and again become sparrows.

The question is easily answered by any one who will give the matter a little thought. The snow-bird nests from Michigan and Wiseonsin northward, and in antumn many of them stop with us to spend the winter instead of all going farther south as is the 
ease with so many birds. This makes it a true "winter resident," of which, among the sparrows, but five oecur in Indiana.

While here the snow-bird is always seen in small bevies or fanily groups, never singly. A true brotherly and sisterly love seems to animate these groups. Their members are never seen quarreling among thernselves as is so common an oecurrence with their pesky cousins, the English sparrows; but when one is erippled or ailing all the others vie with each other in earrying food to it and giving it every needed attention. "Their ordinary note is a short, sharp, emphatic "chip", rapidly repeated as the bird is thushed; but in the spring, as the days beeome warmer, they delight to sit in the low branches of trees and sing a very sweet, suppressed song, as if tuning up in anticipation of the coning mating in that far northern country for which they will soon depart. All in all, though dull in color and lacking in brilliant song, these little snow-birds have many charning habits, well worthy the study of any one interested in our feathered firiends. Were they forever taken from our midst we would sadly miss them on those days when murky clonds o'erspread the sky and. snow and ice enshroud the lap of earth.

"Better far, ah yes! than no bird

Is the ever-present snow-bird;

Gayly tripping, dainty creature,

Where the snow hides every feature;

Covers fences, field and tree,

Clothes in white all things but thee;

Restless, twittering, trusty snow-bird,

Lighter heart than thine has no bird." 


\section{$\mathrm{X}$.}

While tramping through woodland, field and meadow in search of "first hand" knowledge, I often think of the many riches possessed by the farmer's son which he wots not of. His father's fields have thousands of tenants which he never sees. In their proper season wild flowers of brilliant hue and delightful odor bloom all about him yet are passed unnoticed. Every corner of the old Virginia rail fences holds countless treasures of brilliantly colored insects, yet he knows only the six or eight species of homely ones which are especially injurious to his father's crops. In the proper season the orchards and woodlands on the old homestead are full of sweet singing warblers and vireos whose notes and plumage nay be, for the time being, all his own; yet he sees and hears then not. The rainibow darter and its eousin, the greensided darter, swim up and down the ripples of the brook which flows through the wood's pasture of his eountry home, yet the sunlight which they reflect from their gilded sides ne'er strikes the eyes of the farmer's boy. If I possess treasures I wish to know it and not pass ny life surrounded by them and yet in continual ignorance of their presence.

How many of my readers, for example, whether reared in eountry or eity, have ever seen a cross-bill alive? I lived upon a farm until I was of age and did not know that such a bird existed although it was probably found every winter within a mile of $m y$ home. 
Like the snow-bird, the cross-bill belongs to the great family of Fringillide, whose nembers are commonly known as finches and sparrows-all having a The American thick cone-shaped beak for cracking Cross=bill.
seeds. But the beak of the cross-bill has, in time, undergone a wonderful change, or, in other words, has become adapted to the habits of the bird. For, instear of the two mandibles

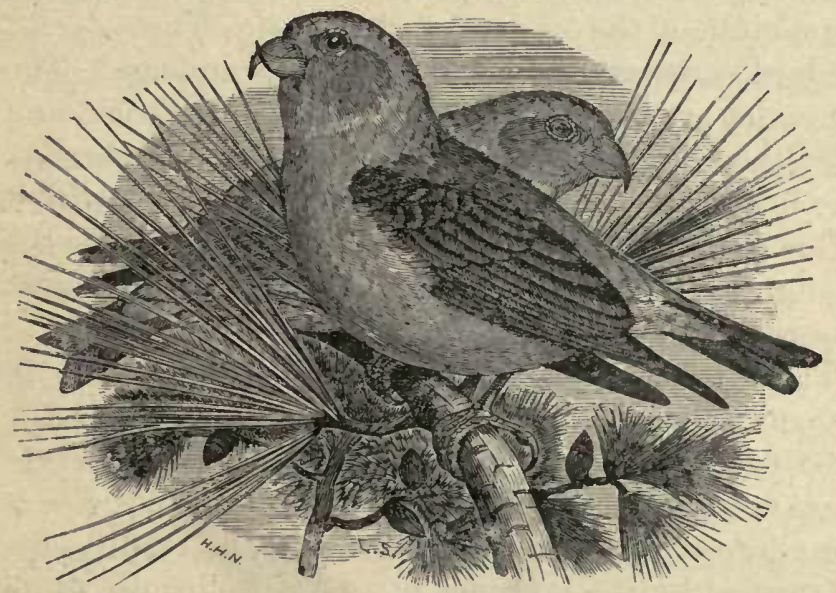

Fig. 84-American Cross-bills. (After Coues.)

meeting on a level as in other finches, the upper "urves down to the right of the lower, which at the same time enrves upward. In this way they partly eross one another, thus giving rise to the common name of the bird.

The bill is thus fashioned to extract the seeds of pines and other similar trees from the cones, and the cross-bills, by the great strength of the muscles of the 
jaw and these strong, oppositely curved mandibles, are able to pry open the tightly appressed scales of the cones and extract at pleasure the nutritious oily seeds. Other birds are equally fond of these seeds, but have to wait for the alternate thawing and freezing of spring to loosen the scales.

In size the cross-bill is somewhat larger than the English sparrow, measuring about $6 \frac{1}{2}$ inches in length. The wings are very long and pointed, reaching beyond the middle of the narrow, forked tail. The color of the bird varies greatly according to sex and age. The old males are brick-red, darkest across the back, and have the wings and tail a uniform blackish-brown. The females of all ages are dull greenish-olive with a yellowish tinge on the crown and rump; while the young males are a curious mixture of brick-red, greenish-olive, and yellowish.

There are two species of cross-bills occurring in Indiana, and the above description applies to the most common one which is known by the name of the American or red cross-bill. The other speeies is the white-winged cross-bill and may be readily distingnished by the presence of two conspicnous white bars across each wing. It has the same habits as the one above described, but has been noted in the State only on a few occasions.

The scientific name of the American cross-bill is Ioxia curvirostra L., from two Latin words meaning "crooked" and "curve-bill"; while that of the whitewinged species is Loxia leucoptera Gmelin, the word "lencoptera" meaning "white-wing." Thus the scientifie name of each kind of plant or animal is often 
based upon some important and noticeable character possessed by the species.

Perhaps no birds are more erratic in their movements than the cross-bills. They appear and disappear from a given locality in the most unexpected manner. In Indiana they are most likely to be found during severe weather in January and February. They go in flocks of from six to forty individuals, usually flying high in air and for great distances at a time. While on the wing they keep up, almost continually, a loud clear call note, which is quite similar to that made by a young chicken in distress. Always alighting in the tops of pines or other evergreen trees, each individual chooses a cone and immediately begins to extract the seeds.

While thus feeding they are extremely gentle and social, easily approached, and may even be knocked down with sticks. In the old barbarous collecting days I have shot as many as five or six from a single tree without causing the remainder of the flock to take flight. The two species are alike in all their habits, climbing from cone to cone like parrots, head down or head up at will; twittering as they feed like many other sparrows; and finally, having eaten their fill, with one impulse they hurry out of sight, to be gone, it may be, until another year rolls by.

They nest throughout the coniferous forests of the northern United States and Canada and in the mountains of the southern States, notably in North Carolina and Tennessee. A few of the young of the previous season either remain in Indiana throughont the summer, or visit here at that season, for I have 
taken them in Putnam County in July, but no well anthenticated record of their nesting in the State has, as yet, been made.

Among the superstitious many curious legends exist acconnting for the origin of certain well known characters of our common birds. For example, the red breast of the robin is said to have resulted from a habit that these birds had, in the misty past, of filling their bills with water which they carried to the brink of Hades and dropped down to the thirsty unfortunates below, their breasts meanwhile becoming scorched by the flames from the infernal regions. In like manner the curved mandibles of the cross-bills are accounted for by saying that these merciful birds tried to pull the nails from the cross, and in so doing twisted their bills in such a way that they will always bear the symbol of their good deed.

\section{XI.}

When, after a few weeks of imprisonment within the city, the naturalist goes forth to make new friends among the denizens of the woods and fields, the pure country air has, at times, a curious effect upon his mind, causing strange thoughts to well up therein concerning the relations of man to the animals and plants about him, and especially to the earth itself. Thus, on one of the pleasant afternoons of late February, as I tramped over a wooded knoll east of the city, I found myself likening the earth to a great round animal, moving on an eternal journey through space, and of mankind as mites, preying upon its 
back, seratching its thick rough hide with their tiny inplements of toil and so causing it to yield them sustenance as does the mite or tick the animal it lives "1pon.

The sight of the smooth lichen-covered bole of a beech eansed this revery to vanish and I began to ponder over the power of sunlight, which, after traveling ninety and more millions of miles, had built up the carbon, hydrogen and oxygen, which the roots and leaves had gathered, into thousands of pounds of solid wood for the use of man. Even the green slime or protococeus found on the north side of the tree has its part to bear in the economy of nature. For it is composed of myriads of little cells, each a complete plant in itself and one of nature's disinfeeting organs; which, by the aid of the all powerful light of the sun, takes up the impure earbon-dioxide and sets free oxygen, pure and invigorating, for man and beast.

But in the beech were birds, forms of life of which I was primarily in search. Two species there were which in winter are almost inseparable; namely, the tufted titmonse and the black-eapped chickadee. Both are permanent residents, that is they are found here at all seasons of the year but appear most abundant in winter; probably because the trees are then bare and the birds can be more readily seen.

Both belong to the same family, the Parida, of which we have but five species in Indiana; namely, one titmonse, two chickadees, and two

The Tufted

Titmouse. nuthatches. Of these the tufted titmouse is the largest and yet it is below the average bird in size, measuring but $6 \frac{1}{4}$ inches 
in length. In color it is a miform leaden-gray above, except a narrow streak of black across the forehead. Below, it is a whitish ash, with the sides tinged with dull reddish-brown. The feathers of the heal are long, and, when the bird is excited or angry, can be raised into a conspicuous erest, whence the common nane of "tufted titmouse."

From the black bar across the forehead it is some-

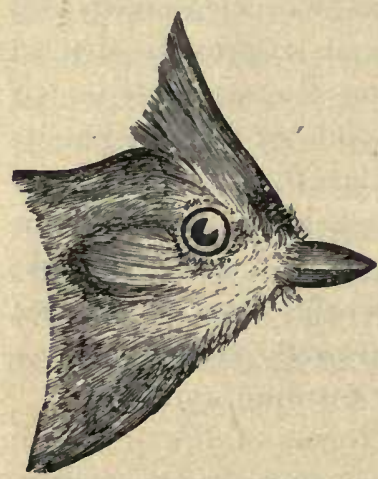

Fig. 85-Head of Tufted

Titmouse. times called the black-fronted titmouse, while its Latin name is Parus bicolor L., the former word meaning "titmouse" and the latter "of two colors."

In winter perlaps no bird is more abundant in the wooded portions of the southern half of Indiana, than this species. Roving in restless, noisy troops through the woods, scolding at every intruder and ealling to one another in harsh tones, it soon renders itself conspicuous to every one who is beginning to take an interest in our feathered fauna. Its ordinary note is a rather monotonous "dee-dee-dee" often repeated as if from habit. Its song is a loud clear whistle resembling the syllables "peto-peto-peto" uttered in a defiant tone; as if challenging all other birds within the compass of its voice. When angry it raises its crest and utters a series of chirps which appear to be imitations of the notes of other birds, those of the blue jay being 
recognized. While searching for insect food it moves by short sudden leaps and flights from branch to branch, suspending itself readily in all attitudes.

When forest food is scarce it often approaches gardens and orchards, and then only do we see it on or close to the ground, readly to pick or tear at any vegetable or animal food which may be to its liking. In summer these winter bevies separate; and each pair seeks some natural eavity such as a hollow in the fork of a tree or a deserted hole bored by a woodpecker. This is lined with bits of moss, leaves and grass, and in it the eggs, four to six in number, are leposited. In color they are white, sprinkled with reddish-brown and lilae, and measure $.75 \times .56$ of an inch.

\section{XII.}

The black-capped chickadee is a better known bird than the tufted titmouse, its colors being more striking and its habits more sociable than that species.

It is also much smaller, measuring but five inches from point of beak to tip of tail. The crown, nape, chin and throat are a rich glossy black, and contrast strongly with the grayish ash of the remainder of the body.

As stated above, both these birds belong to The the same family

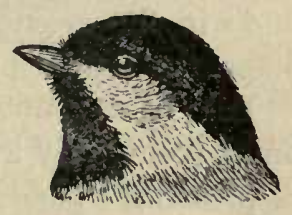

Fig. 86-Head of Blackcapped Chickadee.
Black-capped

Chickadee.

and even to the same genus, so that the first part of the Latin name, Parus atricapillus L., is the same for both. Atricapillus 
means "black haired," and a eommon name, perhaps as mueh used as the one mentioned, is "black-capperl titmouse." It was of this fluffy little bird in its modest dress of black and gray that Emerson wrote as follows:

"This poet, though he live apart,

Moved by his hospitable heart,

Sped, when I passed his sylvan fort,

To do the honors of his court,

As fits a feathered lord of land;

Flew near, with soft wing grazed my lıand,

Hopped on the bough, then darting low,

Prints his small impress on the snow,

Shows feats of his gymnastic play,

Head downward, clinging to the spray.

Here was this atom in full breath,

Hurling defiance at vast death;

This scrap of valor just for play

Fronts the nortl-wind in waistcoat gray."

He is indeed a joyful little creature, Hitting ever about, hither and thither, elinging to the side of a tree one minute and pieking at the moss on a branch the next. His ordinary food eonsist's of the insects which hide in the erevices of bark, spiders' eggs, and, perhaps, the tender buds of trees.

His winter note of "tche-de-de-de-de" is the one most commonly known, but in spring it gives way to a pleasing "phe-be" which is, perhaps, his verial love call.

The nest is built in a dead stump or tree in a hole excavated by the bird itself. The eggs are white, - sprinkled with reddish brown and measure $.58 \times .47$ of an inch in size. 
All the members of the family Paridoe delight to wander in company and time and again have I found all five of them within an area of a few square rods. On the beech tree above mentioned, there were, however, but the two of which I have written, "the lordly tomtit, with his jaunty erest; the merry chickadeethe former making the woods ring with his earnest

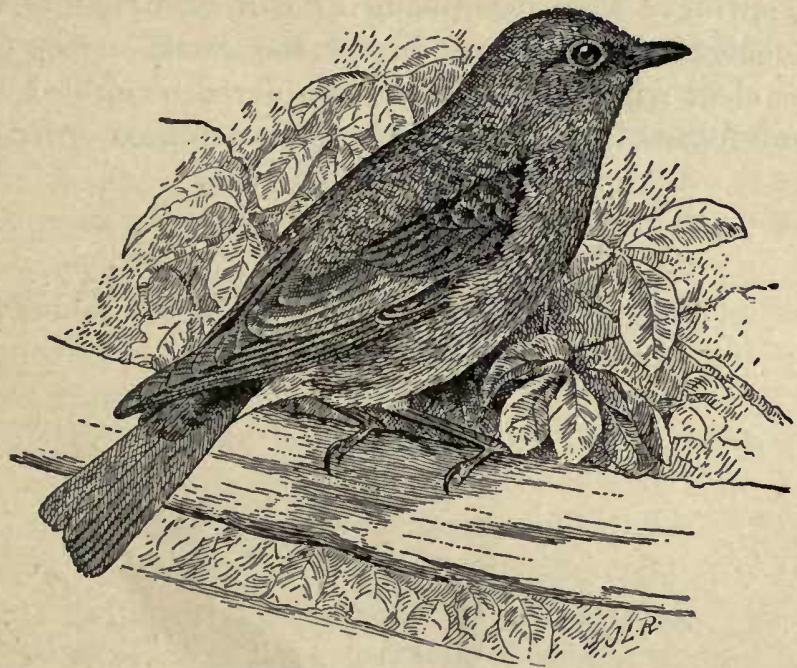

Fig. 87-Bluebird. (After Beal.)

invitation to ramble therein: here-here-here! the latter ever winsome as it ehirped, in more subdued tones, chick-a-dee-dee-dee-dee; winter no terror has for me-for me."

On the same afternoon the notes of many other birds were heard; notably the ringing quaver of the bluebird again and again-the first symbol of the approaching springtime which all plants, all animals 
weleome with marks and notes of joy. It was the beginning of a great awakening which once each year comes to all animate life. A few of the insects, plants, ete., began that day to rub their eyes and endeavor to peep forth to see if a new morning was really beginning to dawn. A few days of such weather and they will begin to call to one another the "good morning" of spring. The matin-song or call was that of the bluebird. The hum of insect, the croak of frog and the clear whistle of the red-shouldered blackbird will soon follow in regular and long accustomed order. 


\section{HOW PLANTS AND ANIMALS SPEND THE WINTER.**}

One of the greatest problems which each of the living forms about us has had to solve, during the years of its existence on earth, is how best to perpetuate its kind during that cold season which once each year, in our temperate zone, is bound to eome. Many are the solutions to this problem. Each form of life has, as it were, solved it best to suit its own peculiar case, and to the earnest student of Nature there is nothing more interesting than to pry into these solutions and note how varied, strange, and wonderful they are.

To fully appreciate some of the facts mentioned below it must be borne in mind that there is no such thing as "spontaneous generation" of life. Every cell is the offspring of a pre-existing cell. Nothing but a living thing can produce a living thing. Hence every weed that next season will spring up and provoke the farmer's ire, and every insect which will then make life almost intolerable for man or beast, exists throughout the winter in some form.

If we begin with some of the lowly plants, such as the fresh-water algæ, or so-called "frog-spittle" of the ponds, and many of the rusts and fungi which are so injurious to crops, we find that they form in antumn "resting spores." These are very small and globular,

* Popular Science Monthly, February, 1897. 
one-celled bodies, having a much thicker coat and denser protoplasm or contents than are found in the spores often produced in summer by the same plants, and which are destined for immediate growth. The power of life within these winter resting spores is proof against the severest attacks of frost, and they lie smugly enseoneed in the mud at the bottom of pond or stream, or buried beneath the leaves in some shel-

\section{Rusts and Fungi} in Winter. tered nook, until the south winds of March or April furnish the key to unlock the castle of the ice king. Then the spirit of growth within each spore begins to assert itself once more, and, bursting the walls, the contents soon produce the parent or summer form of the plant with which we are most familiar. Thus the spores which the next season will produce the grape mildew and the red rust of wheat exist throughout the winter-the former within the substance of the fallen grape leaf, the latter within the stubble or about the roots of the last season's wheat plants.

If the grape leaves should be carefully gathered and burned, and the stubble destroyed in like mamner, not only would the next season's erop of these two parasitic plant pests be wonderfully lessened, but many injurious insects would at the same time be destroyed.

Higher in the scale of plant life we find the flowering annuals bending all their energies during the summer to produce that peculiar form, the "seer," which is only a little plant boxed up to successfully withstand the rigors of winter. The great sunflower, that grows into a giant in a single season and defies 

XIV.

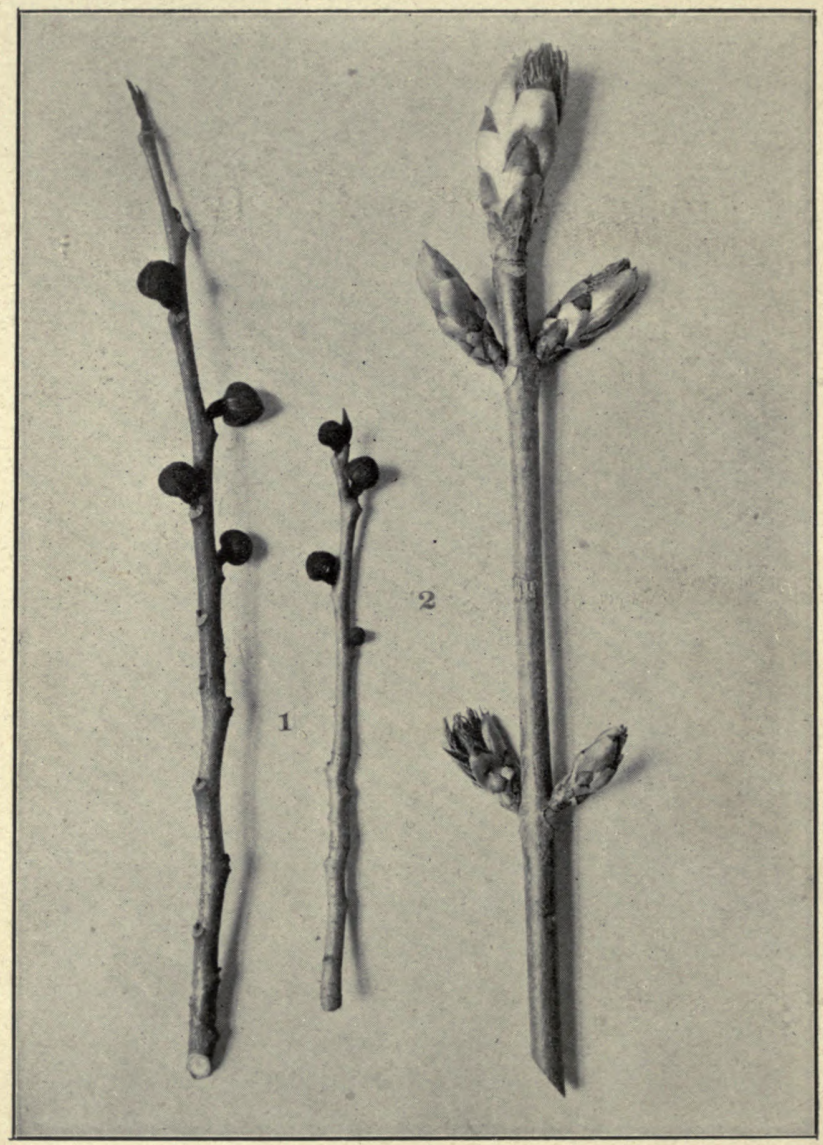

Winter Buds.

1. Papaw.

2. Buckeye. 
the summer sun and storm, falls an easy victim to the frosts of autumn. It, however, prepares the way for many successors in the ripened seeds, each one of which, under favorable conditions, will germinate, grow, reproduce its kind, and thus eomplete another cycle in the realm of vegetable life. The prospective life and activity of a whole field of next summer's waving corn may be considered as stored up in a few pecks of comparatively lifeless seed corn safely housed in the granary. Within its two protecting coats and surrounded by a large store of food, in the form of seed leaf or nucleus, to be used when growth begins again, each little plantlet lives and survives the coldest blasts of King Boreas and his cohorts.

Note, too, the buds and under-ground stems which will furnish the beginning of next season's growth of our biennial and perennial plants. See how they are protected by heavy overcoats in the Winter form of bud seales. Oftentimes, too, as

Bud Scales. in the hickory and "balm of Gilead" trees, these scales have a coat of resin or gum on the outside to render them waterproof; and some, as those of the papaw, are even fur-lined, or rather fur-covered, with a coating of soft black hairs. Were these protective scales not present, the tender shoots within them, which will furnish the nueleus for next season's foliage, would be seared and withered by the first frost as quickly as though touched with a red-hot iron.

The above are some of the many ways in which our plants, in the course of ages and many changes of environment, have solved the problem of surviving the cold of winter. Moreover, they always prepare 
for this cold in time, the resting spores and seeds being ripened and the bud scales formed over the tender tips of the branches long before the first severe frost appears.

Let us now take up those higher forms of life-called animals - "higher," beeause they are absolutely dependent upon plants for their food-and see how they pass their time while their food producers, the plants, are resting.

Beginning with the earth-worms and their kindred, we find that at the approach of winter they burrow deep down where the icy breath of the frost never Earth-worms reaches, and there they live, during
in Winter.
quiet. That they are excedingly sensitive to warmth, however, may be proven by the fact that when a. warm rain comes some night in February or March, thawing out the crust of the earth, the next morning reveals in our dooryards the mouths of hundreds of the pits or burrows of these primitive tillers of the soil, each surrounded by a little pile of pellets, the castings of the active artisans of the pits during the night before.

If we will get up before dawn on such $\varepsilon$ morning we ean find the worms crawling actively about over the surface of the ground, but when the first signs of day appear they seek once more their protective burrows, and only an oceasional belated individual serves as a breakfast for the early birds.

The eyes of these lowly creatures are not visible, and consist of single special cells seattered among the epidermal cells of the skin, and connected by means 
of a sensory nerve fiber with a little bunch of nervous matter in the borly. Such a simple visual apparatus serves them only in distinguishing light from darkness, but this to them is most important knowledge, as it enables them to avoid the surface of the earth by day, when their worst enemies, the birds, are in active search for them.

The fresh-water mussels and snails and the crayfish burrow deep into the mud and silt at the bottom of ponds and streams where they lie motionless during

Mussels and Snails in Winter. the winter. The land snails, in late autumu, crawl beneath logs, and, burrowing deep into the soft mold, they withdraw far into their shells. Then each one forms with a mucous secretion two thin transparent nernbranes, one aeross the opening of the shell and one a little farther within, thus making the interior of the shell perfectly air-tight. There for five or six months he sleeps, free from the pangs of hunger and the blasts of winter, and when the balmy breezes of spring blow up from the south he breaks down and devours the protecting membrane and goes forth with his home on his back to seek fresh leaves for food and to find for himself a mate.

Next in the seale come the insects, which comprise four-fifths of all existing animals, and each one of the mighty horde seen in summer has passed the winter in some form. One must look for them in strange places and under many disguises; for they ean not migrate, as do the majority of the birds, nor ean they live an active life while the source of their food supply, the plants, are inactive. 
The majority of those insects which in May or June will be found feeding on the buds or leaves of Eggs of Insects the grass of our lawns, or burrow-
in Winter. ing beneath the roots of our garden plants, are represented in the winter by the egrgs alone. These eggs are deposited in autumn by the mother insect, on or near the object destined to furnish the young, or larve, their food. Each egg corresponds to a seed of one of our annual plants; being, like it, but a form of life so fashioned and fitted as to withstand for a long period intense cold; the mother insect, like the summer form of the plant, snecumbing to the first severe frost.

Thus myriads of the eggs of grasshoppers are in the early antumn deposited in the cround, in compact masses of forty to sixty each. About midApril they begin to hatch, and the sprightly little insects, devoid of wings, but otherwise like their parents, begin their life-work of changing grass into flesh.

A comparatively small number of insects pass the winter in the larval or active stage of the young. Of these, perhaps the best known is the brown "woolly Larva of Insects it is familiarly called. It is thickly in Winter. covered with stiff black hairs on each end, and with reddish hairs on the middle of the body. These hairs appear to be evenly and closely shorn, so as to give the animal a velvety look; and as they have a certain degree of elasticity, and the caterpillar curls up at the slightest touch, it generally nun- 
ages to slip away when taken into the hand. Beneath loose bark, boards, rails and stones, this caterpillar may be found in midwinter, eoiled up and apparently lifeless. On the first bright, sumny days of spring it may

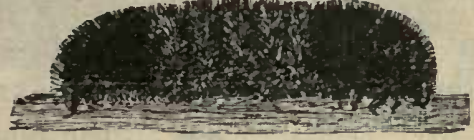

Fig. 85-Hedgehog Caterpillar. be seen crawling rapidly over the ground, seeking the earliest regetation which will furnish it a literal "breakfast." In April or May the ehrysalis, surrounded by a loose cocoon formed of the hairs of the body interwoven with coarse silk, may be found in situations similar to those in whieh the larva passed the winter. From this, the perfect inseet, the Isabella tiger moth, Pyrrharctia isabella Smith, emerges about the last of June. It is a medium sized moth, dull orange in eolor, with three rows of small black spots on the body, and some seattered spots of the same eolor on the wings.

By breaking open rotten logs one can find in midwinter the grubs or larva of many of the wood-boring beetles, and, beneath logs and stones near the margins of ponds and brooks, hordes of the maggots or larve of certain kinds of flies may often be found huddled together in great masses. The larra of a few butterflies also live over winter beneath ehips or bunches of leaves near the roots of their foor plant, or in webs of their own construction, which are woven on the stems close to the buds, whose expanding leaves will furnish them their first meal in spring.

Many insects pass the winter in the quiescent or pupal stage; a state exceedingly well fitted for hiber- 
nating, requiring, as it does, no food, and giving Pupa of Insects plenty of time for the marvelous in Winter. changes which are then undergone. Some of these pupre are enclosed in dense silken cocoons, which are lound to the twigs of

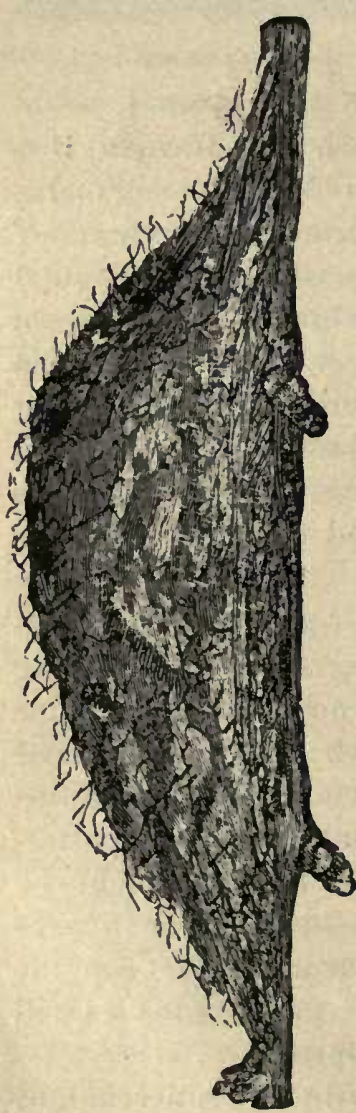

Fig. 89-Cocoon of Cecropian Moth. the plants upon which the larvæ feed, and thus they swing securely in their silken hammoeks through all the storms of winter. Perhaps the most common of these is that of the brown Ceeropian moth, Attacus cecropic L., the large oval cocoon of which is a conspicuous object in the winter on the tivigs of our common shade and fruit trees. Many other pupre may be found beneath logs or on the under side of bark, and usually have the chrysalis surrounded by a thin covering of hairs, which are rather loosely arranged. A number pass the cold season in the earth with no protective covering whatever. Among these is a large brown ehrysalis with a long tongue case bent over so as to resemble the handle of a jug. Every farm boy has plowed or spaded it up in the spring, and it is but 
the pupa of a large sphinx moth, Protoparce celeus Hub., the larva of which is the great green worm, with a "horn on its tail," so com-

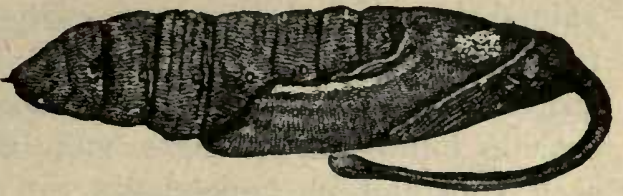

Fig. 90-Chrysalis of Tomato Worm. mon on tomato plants in the late summer.

Each of the winter forms of insects above mentioned can withstand long and severe cold weather-in fact, may be frozen solid for weeks and retain life and vigor, both of which are shown when warm weather and food appear again. Indeed, it is not an unusually cold winter, but one of successive thawings and freezings, which is most destructive to insect life. A mild winter encourages the growth of mold which attacks the hibernating larve and pupæ as soon as, from excess of rain or humidity, they become sickly; and it also permits the continued activity of insectivorous mammals and birds. Thus, moles, shrews, and field mice, instead of burying themselves deeply in the ground, run about freely during an open winter and destroy enormous numbers of pupe; while such birds as the woodpeckers, titmice, and chickadees are eonstantly on the alert, and searching in every crevice and cranny of fence and bark of tree for the hibernating larvæ.

Of the creeping, wingless creatures, which can ever be found beneath rocks, rails, chunks, and especially beneath those old decaying logs which are half buried in the rich vegetable mold, the myriapods, or "thousand-legs," deserve more than a passing notice. They 
are typical examples of that great branch of the animal kinglom known as arthropods, which comprises all insects and crustaceans. Each arthropod has the body composed of rings placed end to end and bearing jointed appendages, and in the myriapods each ring and its appendages can be plainly seen; whereas in the higher forms of the branch many of the rings are so combined as to be very difficult to distinguish.

Full forty kinds of myriapods occur in any area comprising one hundred square miles in the eastern United States. About twenty-five of then go by the

Myriapods in

Winter. general name of "thousand-legs" or millipedes, as each has from forty to fifty-five cylindrical rings in the borly, and two pairs of legs to each ring. The other fitteen belong to the "centipede" group, the borly consisting of about six-

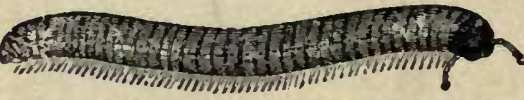

Fig. 91-Millipede or "Thousand Legs." teen flattenel segments, or rings, eacl। bearing a single pair of legs. When disturbed, the "thousant-legs" generally coils up and remains motionless, shanmuing death, or "playing possum," as it is popularly put, as a means of defense; while the centipede scampers hurriedly away and endeavors to hide beneath leat, chip, or other protecting object.

All those found in the Northem States are perfectly hamless, the true centipede, whose bite is reputed much more venomons than it really is, being found only in the South. True, some of the centipede group can pinch rather sharply with their bectle-like jaws; 
and one, our largest and most common species, a brownish red fellow about three inches long and without eyes, can even draw blood if its jaws happen to strike a tender place. When handled, it always tries to bite, perhaps out of revenge for the abominably long Latin name given it by its deseriber. In fact the name is longer than the animal itself-Scolo-po-cryp-tops sex-spi-no-sus (Say)-be-

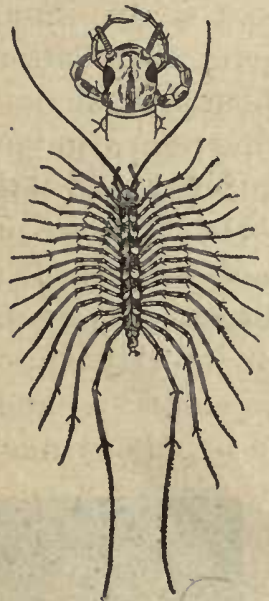

Fig. 93-Wall-sweeper.

(Two-thirds natural size; also hearl much enlarged. After Liutner.)

ing its cognomen in full. With sueh a liandle attached to it, who can blame it for at-

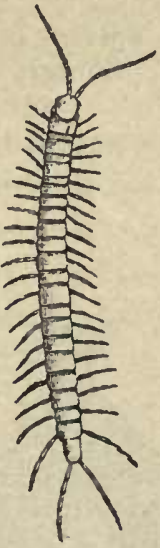
tempting to bite? Fig. 92-Contipede. Yet, to the scientist up on his Latin, each part of the above name bears a definite and tangible nieaning. All the myriapods found in the woods and fields feed upon deeaying vegetation, such as leaves, stems of weeds, and rotten wood, and in winter three or four speeies can usually be found within or beneath every decaying log or stump. One species with very long legs, Scutigera forceps (Raf.), is often found in damp houses or in cellars. It is sometimes called the "wall-sweeper,", on aceount of its rapict ungainly gait; and is even reputed to prey upon cockroaches and other household pests. 
Spiders, which do not undergo such ehanges as do most of the common, six-footed inserts, winter either

Spiders in Winter.

as eggs or in the mature form. The members of the "sedentary" or webspinning group, as a rule, form nests in late autumn, in each of which are deposited from fifty to eighty eggs, which survive the winter and hateh in the spring, as soon as the food supply of gnats, flies

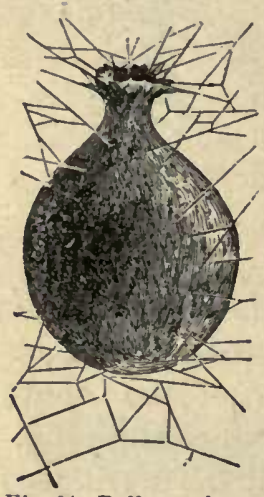

Fig. 94-Balloon-shaped Nest of Spider. (After Comstock.) and mosquitoes appear. The different forms of spiders' nests are very interesting objects of study. Some are those close-spun, flat, buttonshaped objects, about half an inch in diameter, which are so common in winter on the under side of bark, chunks and flat rocks. Others are balloon-shaped-and attached to weeds. Within the latter the young spiders often hatch in early winter, make their first meal off their empty egg cases, and then begin a struggle for existence, the stronger preying upon the weaker until the south winds blow again, when they emerge and scatter far and wide in search of more nutritious sustenance.

The "wandering" spiders never Fig. 95-Spider's Nest. spin webs, but run actively about (After Comstock.) and pounce upon their prey with a tiger-like spring. Six or eight of the larger species of this group winter in the mature form beneath logs and chunks, 
being often frozen solid during cold weather, but thawing out as healthy as ever when the temperature rises. Retiring beneath the loose-fitting bark of hickory or maple trees, a number of the smaller tube-weaving spiders construct about themselves a protecting web of many layers of the finest silk. Within this snug retreat they lie from November until April-a handsome, small, black fellow, with green jaws and two orange spots on his abdomen, being the most common species found motionless within this seeming shrond of silk on a day in midwinter.

In any Northern State as many as four hundred* different kinds of the six-footed or true insects, in the winged or adult stage, may be taken in winter by any one who is so disposed, and knows where to search for them. Among the Orthoptera, the "grouse grasshoppers" live during the cold season beneath the loose bark of logs, or beneath the bottom rails of the old Virginia worm fences: From these retreats every warn, sunny day tempts them forth in numbers. On such occasions the earth seems to swarm with them, as they leap before the intruder, their hard bodies striking the dead leaves with a sound similar to that produced by falling hail. The common tield cricket belongs also to the Orthoptera, and the young of various sizes winter under rails and logs, bidding defiance to Jack Frost from within a little burrow or pit beneath the protecting shelter.

* See Psyche, 1895 and 1896, for notes on 286 species of Culeoptera, 64 of Hemiptera and 18 of Orthoptera taken by the writer in Vigocounty, Indiana, during the winter months. 
The true bugs, or Hemiptera, hibernate in similar places; squash bugs, chinch bugs, "stink" bugs, and other's being easily found in number's beneath loose bark or hidden between the root leaves of mullein and other plants.

Nearly three hundred species of Coleopter, or beetles, occupy similar positions. Almost any rotten $\log$ or stump when broken open discloses a half dozen or more "horn"

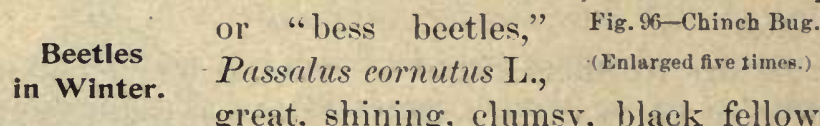
great, shining, elumsy, black fellows with a curved horn on the head. They are often

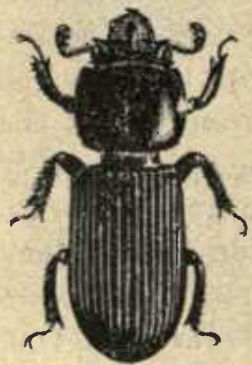

Fig. 97-Horn or Bess Beetle.

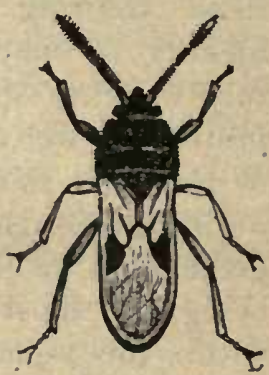

Fig. 96-Chinch Bug. (Enlarged fire times.) utilized as horses by country children, the horn furnishing an inviting projection to which may be fastened, by a thread or cord, chips and pieces of bark to be dragged about by the strong and never lagging beast of burden. When tired of "playing horse" they can make of the insect an instrument of $\mathrm{mu-}$ sic; for, when held by the body, it emits a creaking, hissing noise, produced by rubbing the abdomen up and down against the inside of the hard, horny wing covers. This beetle passes its entire life in cavities in the rotten wood on which it feeds, and when it wishes a lal gel or more conmodious home it has only to eat the more. 
The handsome and beneficial lady beetles winter beneath fallen leares or between and beneath the root leaves of the mullein and the thistle. Our most common species, the thirteen-spotted lady beetle, Megilla maculata DeG.; is gregarious, collecting together by thousands on the approach of cold weather, and lying huddled up like sheep until a breath of spring gives them the Fig. 98-Thirteen-spotsignal to disperse. Snout beetles

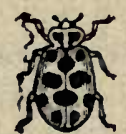
galore can be found beneath piles of weeds near streams and the borders of ponds or beneath chunks and logs in sandy places. All are injurions, and the farmer by burning their hibernating, places in winter can cause their destruction in numbers. Rove beetles, ground beetles, and many others live deep down in the vegetable mold beneath old logs, where they are, no doubt, as secure from the breath of the ice king as if they had followed the swallow to the tropies.

Of the Liptera, or flies, but few forms winter in the perfect state, yet the myriads of house flies and their kin, which next summer will distract the busy house-

\section{Flies and Gnats} wife, are represented in winter by a in Winter. few isolated individuals which creep forth oceasionally from crevice or cranny and greet us with a friendly buzz.

In mid-winter one may also see in the air swarms of small, gnat-like insects. They belong to this order and live beneath the bark of freshly fallen beech and other logs. On warm, sunny days they go forth in numbers for a sort of rhythmical conrtship; their movements while in the air being peculiar in that 
they usually rise and fall in the same vertical lineperforming a curions aẻrial danee which is long eontinued.

Among the dozen or more butterflies and moths which winter in the perfect state, the most common and the most handsome is the "Camberwell beauty" or "mourning eloak," Vanessa antiopa L., a large butterfly whose wings are a rich purplish brown above, duller beneath and broadly margined with a yellowish band. It is often found in winter beneath chunks which are raised a short distanee above the ground, or in the erevices of old snags and fence rails. It is then apparently lifeless, with the antennæ resting elose along the back, above which the wings are folded. But one or two warm days are necessary to restore it to activity, and $I$ have seen it on the wing as early as the $2 d$ of March, hovering over the open flowers of the little snow trillium.

All the species of ants survive the winter as mature

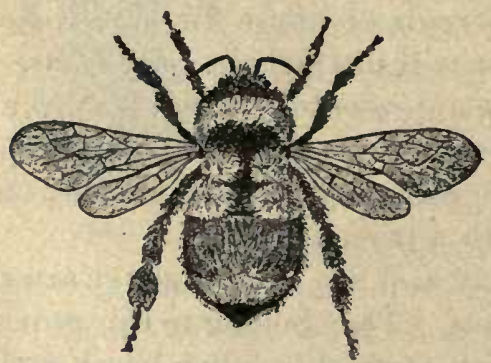

Fig. 99-A Queen Bumble-bee.

forns, either in their nests in the ground or in huddled groups in. half rotten $\operatorname{logs}$ and stumps; while here and there beneath logs a solitary queen bumble-bee, bald hornet, or yellow jacket is found -the sole representatives of their races.

Thus inseets survive the winter in many ways and in many places, some as eggs, others as larvæ, still 
others as pupre, and a large number as adults-all being able to withstand severe cold and yet retain vitality sufficient to recover, live, grow, and replenish the earth with their progeny when the halcyon days of spring anpear once more.

In the scale of animal life the vertebrates or backboned animals succeed the insects. Beginning with the fishes, we find that in late autumn they mostly seek some deep pool in pond or stream at the bottom

Fishes in Winter. of which the water does not freeze. Here the herbivorous forms eke out a precarious existence by feerling upon the innumerable diatoms and other small plants which are always to be found in water, while the carnivorous prey upon the herbivorous, and so maintain the struggle for existence. The moving to these deeper channels and pools in autumn and the scattering in the spring of the assembly which has gathered there constitute the so-called "migration of fishes," which is far from being so extensive and methodical as that practiced by the migratory birds.

Many of the smaller species of fishes, upon leaving these winter resorts, ascend small, clear brooks in large numbers for the purpose of depositing their eggs; as, when hatehed in such a place, the young will be comparatively free from the attacks of the larger carnivorous forms. Anong the lowest vertebrates often found in numbers in early spring in these meadow rills and brooks is the lamprey, Ammocotcs branchialis (L.), or "lamper eel," as it is sometimes called. It has a slender, eel-like borly, of a uniform leaden or blackish color, and with seven purse-shaped 
gill openings on each side. The mouth is fitted for sucking rather than biting, and with it they attach themselves to the bodies of fishes and feed on their flesh, which they scrape off with their rasp-like teeth. Later in the season they disappear from these smaller streams, probably returning in mid-summer to deeper water. Thoreau, who studied their habits closely, says of them: "They are rarely seen on their way down stream, and it is thought by fishermen that they never return, but waste away and die, clinging to rocks and stumps of trees for an indefinite period; a tragic feature to the scenery of the river bottoms worthy to be remembered with Shakespeare's description of the sea floor."

A few of the fishes, as the mud minnow and smaller catfishes, together with most frogs, turtles, and sala-

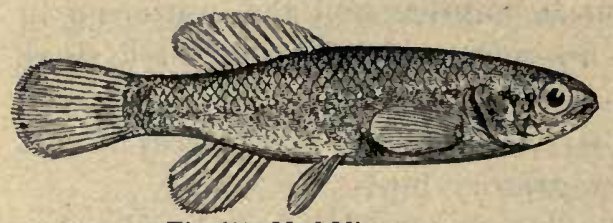

Fig. 100-Mud Minrow.

Umbra limi (Kirtland). manders, on the approach of winter, burrow into the mud at the bottom of the streams and ponds, or beneath logs near their margins. There they live withont moving about and with all the vital processes in a partially dormant condition, thus needing little if any food.

The box tortoise or "dry land terrapin," the common toad, and some salamanders burrow into the dry earth, usually going deep enongh to escape frost; while snakes seek some crevice in the rocks or hole in the ground where they coil themselves together, 
oftentimes in vast numbers, and prepare for their winter's sleep. In an open winter this hibernation is often interrupted, the animal emerging from its retreat and seeking its usual summer haunts as though spring had come again. Thus I have, on one oceasion, seen a soft-shelled turtle moving gracefully over the bottom of a stream on a day in late Deeember, and have in mid-Jannary captured snakes and salamanders from beneath a pile of driftwood, where they had taken temporary refuge.

With frogs, espeeially, this hibernation is not a perfeet one, and there is a doubt if in a mild winter some species hibernate at all. For example, the little ericket frog or "peeper" has been seen many times in midwinter alongside the banks of flowing streams, and during the open winter of $1888-89$ numerous specimens of leopard and green frogs were seen on different oceasions in December and January, while on February 18th they, together with the "peepers," were in full chorus.

Of our manmals, a few of the rodents or gnawers, as the ground-hogs, gophers and chipmunks, hibernate in burrows deep enough to escape the cold, and either feed on a stored supply of food, or, like the snakes and crayfish, do not feed at all.

Others, as the rabbits, field mice, and squirrels, are more or less active and forage freely on whatever they ean find, eating many things which in summer they

The Muskrat would spurn with sen'n. To this elass in Winter. belongs that intelligent but injurious animal the musquash or muskiat. Those which inhabit the rivers and larger streams live 
in burrows dug deep beneath the banks, but those inhabiting sluggish streams and ponds usually construct a conical winter house about three feet in diameter and from two to three feet in height. These houses are made of coarse grasses, rushes, branches of shrubs, and small pieces of driftwood, closely cemented together with stiff, clayey mud. The top of the house usually projects two feet or more above the water, arid when sun-dried is so strong as to easily sustain the weight of a man. The walls are generally about six inches in thickness and are very difficult to pull to pieces. Within is a single circular chamber with a shelf or floor of mud, sticks, leaves and grass, ingenionsly supported on coarse sticks stuck endwise into the mud after the manner of piles. In the center of this floor is an opening, from which six or eight diverging paths lead to the open water withont, so that the little artisan has many avenues of escape in case of danger. These houses are often repaired and used for several winters in succession, but are vacated on the approach of spring. During the summer the muskrat is, in the main, a herbivorons animal, but in winter necessity develops its carnivorons propensities and it feeds then mainly upon the mussels and crayfish which it can dig from the bottom of the pond or stream in which its house is built.

The bats pass the winter in eaves, the attics of honses and barns, or in hollow trees, hanging downward by their hind elaws. Motionless for months they thus remain, and those in the more exposed situations are, donbtless, frozen solid. Yet, in time, their blood flows freely once again and they become as 


\section{XV.}

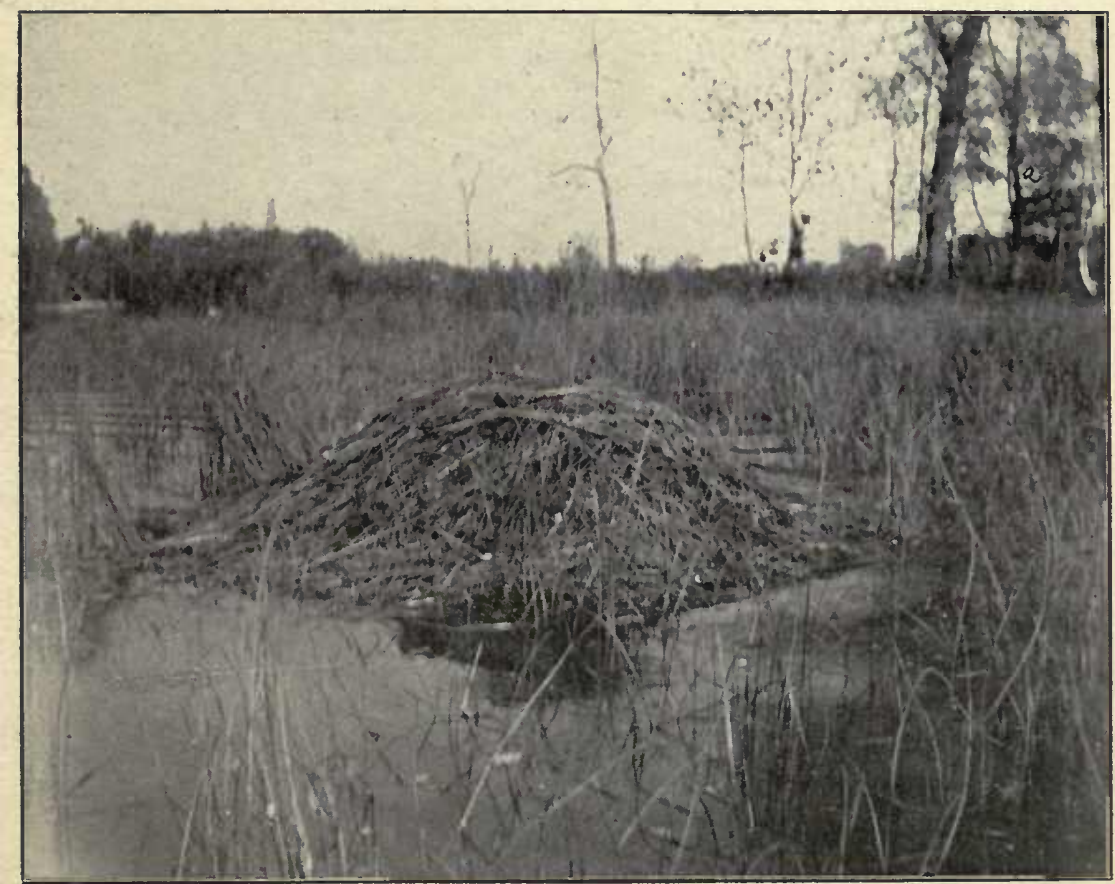

Winter House of Muskrat. 

expert on the wing as though the year were one continual jubilee of insect chasing, and frost and snow were to them unknown.

All the earuivora, or flesh-eaters, as the mink, skunk, opossum, fox and wolf, are in winter active and voracious, needing much food to supply the necessary animal heat of the body. Hence they are then much more bold than in summer, and the hen yard or sheep pen of the farmer is too frequently ealled upon to supply this extra demand.

But of all our animals it seems to me the birds have solved the winter problem best. Possessing an enduring power of tlight and a knowledge of a southern sunny sky, beneath which food is plentiful, they alone of all the living forms about us have little fear of the coming of the frost. True, fifty or more species remain in each of the Northern States cluring the eold season, but they are hardy birds which feed mainly upon seeds, as the snow-bird and song sparrow; on flesh, as the hawks and crows; or on burrowing insects, as the nuthatehes and woodpeckers.

Such are some of the solutions to the problem of life in winter which the plants and animals about us have worked out; such some of the forms which they undergo; the places which they inhabit.

To the thinking mind a knowledge of these solutions but begets other and greater problems, such as how ean a living thing be frozen solid for weeks and yet retain vitality enough to fully recover? How can a warm-blooded animal sleep for months without partaking of food or drink? And, greater than either, what is that which we call life? 
I hold in my hand two objects, similar in size, color, organs, everything-twins from the same mother in all outward respects. One pulsates and throbs with that which we call "life." It possesses heat, bodily motion, animal power. The other is cold, motionless, pulseless, throbless - a thing of clay. What is that "life" which the one possesses and the other lacks? $\mathrm{Ah}$, there's the rub! With the wisest of men we can ouly answer, "Quien sabe?" (Who knows?) 


\section{A SEEKER AFTER GOLD.}

A few months ago I spent a day in the wildest part of Brown county, looking for traces of that precious metal which Dame Rumor says exists in quantity in the fine sand and silt along the streams and in the valleys thereabouts. My eyes, unaceustomed to such work, saw no traces of yellow amidst the gray and the black, and I was beginning to doubt its existenee except in the mind of some enthusiastie seeker, when, on turning a sharp bend in a stream, I came suddenly upon an old man, weather-beaten, roughly clad, gaunt of figure and haggard of face, who was bending over a pan of moist sand and silt which he was shaking with a rocking motion to and fro. So busily engaged in his work was he that he did not notice my approach, and I stood beside him and heard his ejaculation of delight as he reached down and picked from the botton of the pan a piece of gold about double the size of a grain of wheat. "Ah, ny little beanty, I have found you at last," said he; then for the first time noticing my presence, he sprang to his feet with an exelamation of surprise, letting fall his pan in his excitement. His locks were unkempt, his face begrimed, but his eyes sparkled with more than ordinary brillianey and through them was revealed the soul of a man who was an enthusiast in his chosen work-the seareh for gold. 
I engaged him in conversation and found that he had been washing the sands for three weeks and longer, but with very poor success-less than an ounce being the total result of his labor-all in small grains, the one just found being the largest. "I am doing this work more for pleasure than for profit," said he. "I do not have to work, for I spent many years prospecting in the west and funally found a paying lead, sold out and came home, not rich, but with enough to kecp me from want for the reniainder of my days. The bright Indian summer weather of the past few weeks has tempted me forth and again have I been seeking the yellow grains in the sands and gravel of these streams."

Talking farther with him, I found him to be a man of fine education-a graduate of an eastern college, but a life long rover-who, like thousands of others, had given his years, more than thirty of them, to the search for gold-forsaking friends, society, all, in a vain seeking for great wealth.

He invited me to his tent, pitehed on a near-by sumny slope, and there for an hour or longer entertained me with aneclotes of his prospecting life among the hills and mountains of the distant west. Noticing a number of books in the tent, I led him to talk of them, and found his knowledge of poetry to be extensive, Bryant and Wordsworth being his acknowledged favorites. As I was leaving he took from between the covers of one of the volumes a folder piece of paper and handing it to me said: "At times I indulge a little in poetry nyself. Here is a copy of my latest verse. When you get home, read it, and if 
we ever meet again tell me what you think of it." I took it, and, having heard nothing from him sinee, I venture to reproduce it here, as it shows that he realized something of what he had lost in the years gone by, and also that in poetry as in life his favorite theme was gold. It was inscribed "To Some Nuggets of Brown County Gold," and ran as follows :

\section{TO SOME NUGGETS OF BROWN COUNTY GOLD.}

$$
\text { Gold, gold, }
$$

Tiny nuggets of yellow gold,

Brought from the north by a glacier cold,

Borne with the sands and the pebbles old

To the vales of Brown, and there out-doled

To remain alway.

$$
\text { Gold, gold, }
$$

Ever a curse to man the bold,

Luring him forth from his father's fold

To lands far away, where hills uprolled

Forever will be; and bells untolled

Till the judgment day.

Gold, gold,

How many faces are pinched and old,

How many hearts once warm and bold

To-day are timid, and sere and cold,

How many bodies beneath the mold,

For search of thee?

$$
\text { Gold, gold, }
$$

To mortal ear the half's not told

Of men's souls lost and women's sold

For sake of such baubles as these I hold.

Then, curses upon thee, yellow gold,

Forever be. 



\section{INDEX.}

Abbott, C. C., Quoted............ Acridide ................................ 231

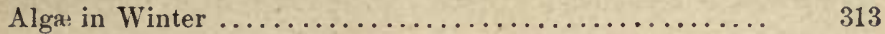

Allen, Grant, Quoted ..................... 245, 248

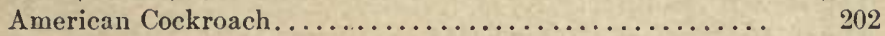

Animals in Winter ......................... 313

Bauded Rattlesnake ........................ 43

Bat, Little Brown .................... 110, 145

Bats in Winter ........................... 332

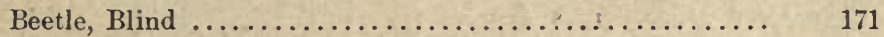

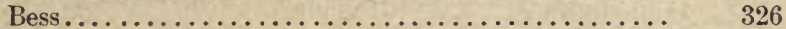

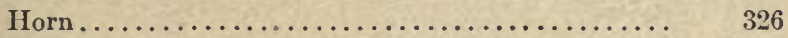

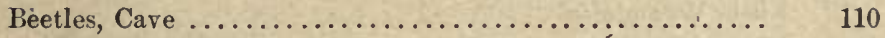

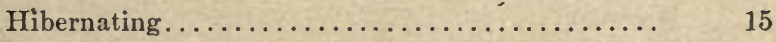

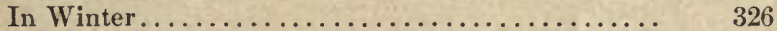

Lady ........................ 327

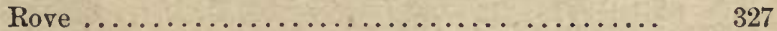

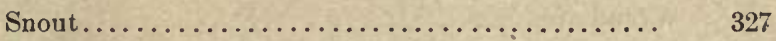

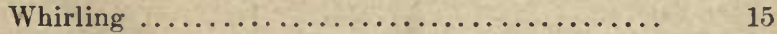

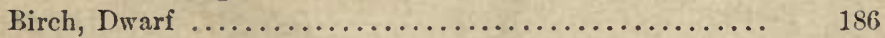

Birds, Destruction of Haunts of ................ 296

In Winter ....................... 253, 333

Permanent Residents .................... 253

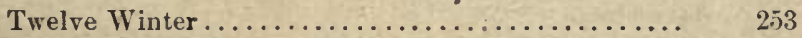

Winter Residents...................... 254

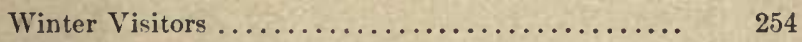

Blackbird, Red-shouldered .................... 17

Blattido................................ 198

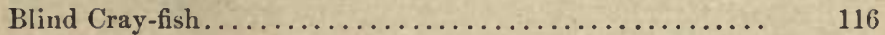

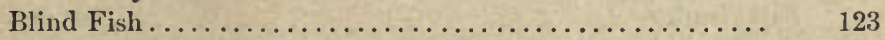

Blue-grass, Kentucky.................... 93, 180

Bluebird............................. 190, 311 
Brook Lamprey

PAGE.

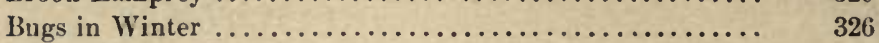

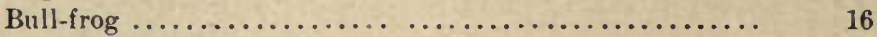

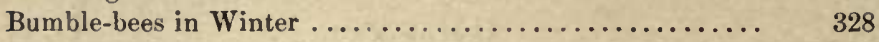

Bunting, Black-throated ....................... 284

Indigo.......................... 86

Butcher Bird............................ $\quad 286$

Butterfly, Velvety-hṛown.................... 12, 328

Butterflies, Hibernating ................... 15, 328

Camberwell Beauty...................... 12, 328

Canal, Mid-summer along the Old ................ 82

Mid-autumn along the Old ............... 189

Tow-path of $\ldots \ldots \ldots \ldots \ldots \ldots \ldots \ldots \ldots \ldots \ldots \ldots \ldots, 85$

Cardinal Flower........................ 85, 93

Caterpillar, Hedgehog ..................... $\quad 318$

Cave, Coon ............................ 107

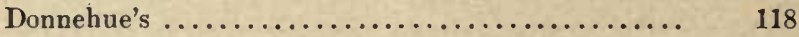

Eller's ............................. 111

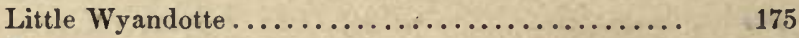

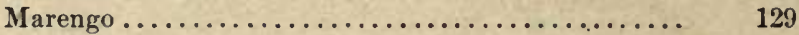

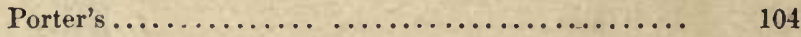

Shawnee ............................ 121

Shiloh .............................. 115

Wyandotte........................ 137

Cave Bats................................. 143, 145

Beetle.............................110, 171

Cricket .............................. 175

Crustacean........................113, 161

Flies .......................106, 110, 158, 168

Harvestman ....................... 128, 154

Moth............................... 157

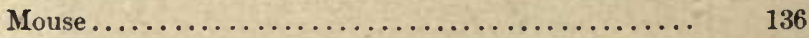

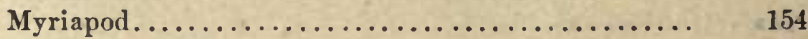

Pseudo-scorpion......................... 166

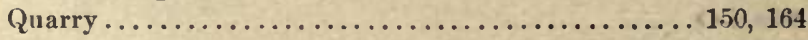

Salamanders........................ 105, 119

Shrimp.............................. 112

Spiders.........................106, 131 
Caves, Clifty.

Formation of .

99

Cecropian Moth.......................... $\quad 320$

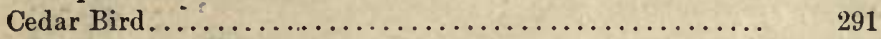

Centipedes in Winter ....................... 322

Chat, Yellow-breasted $\ldots \ldots \ldots \ldots \ldots \ldots \ldots \ldots \ldots \ldots . \ldots \ldots$

Chelifer, Blind.......................... 166

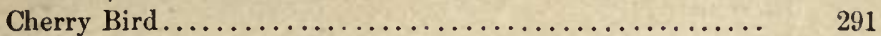

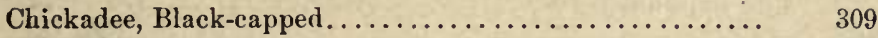

Chinch Bug.............................. $\quad 326$

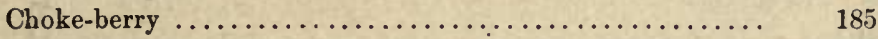

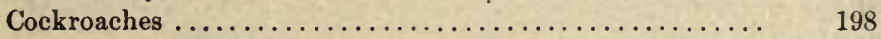

American......................... 202

Oriental ........................ 199

Pennsylvania ...................... 202

Remedy for....................... 207

Composite ................................ 91, 180, 249

Coon Cave................................. 107

Copper-head Snake....................... 42

Coues, Elliot, Quoted................... 77,277

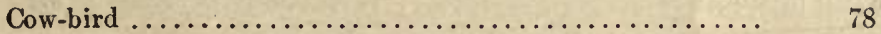

Cranberry .................................. 184

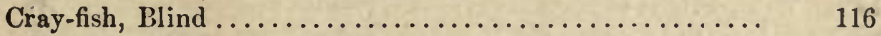

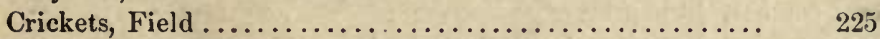

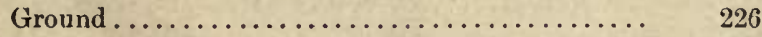

Mole .................................. 223

Stone or Camel ...................... 221

Tree.............................. 229

Cricket Frog............................. 16

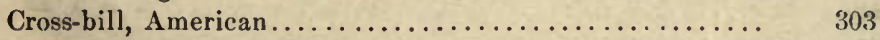

White-winged ........................ 304

Croton Bug .............................. 204

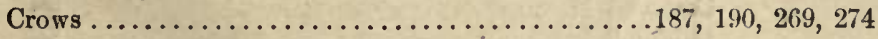

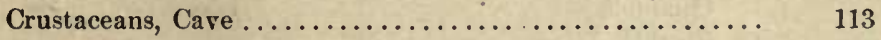

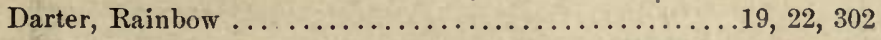

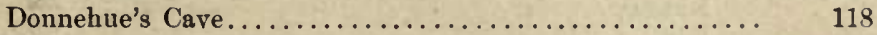

Draba................................... 13 


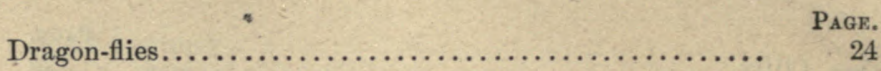

Earth-worms in Winter ....................... $\quad 316$

Eller's Cave............................... 111

Energy, Transmutation of .................... 25, 290

Environment, Effect of ..............22, 125, 128, 137, 158, 283

Fishes, Migration of ...................... 15, 329

In Winter .......................... $\quad 329$

Two Fops among the $\ldots \ldots \ldots \ldots \ldots \ldots \ldots \ldots \ldots, \quad 19$

Flies, Cave ................................... 110

In Winter............................. 327

Flicker ... . . . . . . . . . . . . .

Flowers, Old Fashioned...................... 88

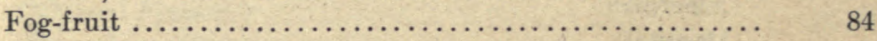

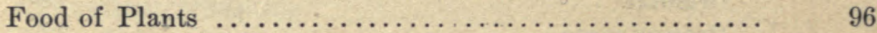

Forbes, Dr. S. A., Quoted ...................22, 273, 299

Fox Sparrow............................. 18

Fringillidae ..............................298, 303

Frog, Cricket ............................ 16

Frogs in Winter........................... 331

Fungi in Winter $. \ldots \ldots \ldots \ldots \ldots \ldots \ldots \ldots \ldots \ldots \ldots \ldots \ldots \ldots, \quad 314$

Geese, Wild, Flight of $\ldots \ldots \ldots \ldots \ldots \ldots \ldots \ldots \ldots \ldots \ldots \ldots$

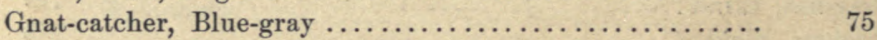

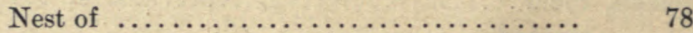

Gnats in Winter.............................. 327

Gold, a Seeker after ......................... 335

Brown County ......................... 335, 337

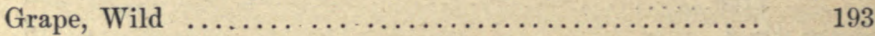

Grass-finch.............................. 190, 299

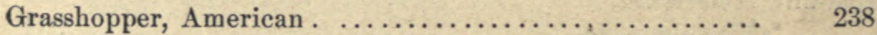

Carolina ........................ $\quad 242$

Common Meadow..................... 220

Cone-headed ........................ 217

Florida ........................... $\quad 241$

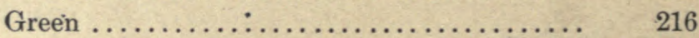

Kansas ............................ $\quad 239$

Lance-tailed ....................... $\quad 219$ 
P $\mathbf{A G E}$.

Grasshopper, Lubberly ...................... 238

Mottled ...................... 187

Red-legged...................... $\quad 239$

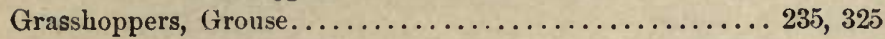

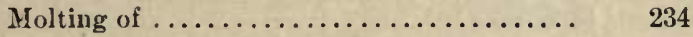

Pea-green ...................... 240

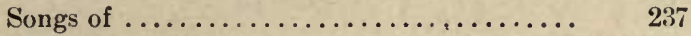

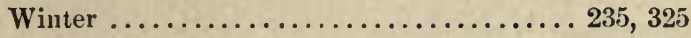

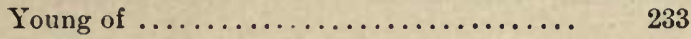

Gravel Pit ................................ 83

Gryllidice............................. 222

Hackberry ............................. 294

Harbingers of Spring $\ldots \ldots \ldots \ldots \ldots \ldots \ldots \ldots \ldots \ldots \ldots, 9$

Harvestman, Cave................................ 154

Hazlenut ............................... 193

Hedge-hog Caterpillar ....................... $\quad 318$

Hepatica ............................... 14

Hornets in Winter......................... 328

Ice Age, the Great....................... 83

Insects, Eggs of, in Winter.................. $\quad 317$

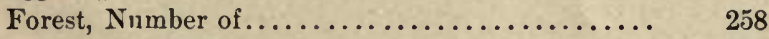

Larva of, in Winter.................... 318

Pupæ of, in Winter.................... $\quad 320$

Interdependence of Plants and Animals............ 12, 290

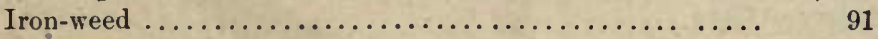

Isabella Tiger Moth ..................... $\quad 319$

Junco, Slate-colored..................... 190, 298

Katydid, Angular-winged $\ldots \ldots \ldots \ldots \ldots \ldots \ldots \ldots \ldots \ldots . \ldots \ldots \ldots \ldots$

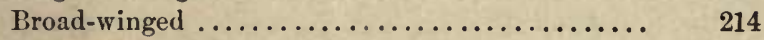

Katydids .............................. 212

Lamper Eel.............................. 329

Lamprey $\ldots \ldots \ldots \ldots \ldots \ldots \ldots \ldots \ldots \ldots \ldots \ldots \ldots \ldots \ldots . . . \ldots \ldots$

Larch, Black ............................. 181

Locustida ................................ $\quad 211$ 
Mammals in Winter

PAGE.

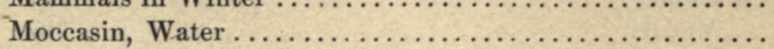

331

Mud Minnow

Muskrat in Winter

Mussels in Winter .

331

Myriapods in Winter

Oriental Roach................................

Orthoptera, Number of in Indiana $\ldots \ldots \ldots \ldots \ldots \ldots \ldots$

Paridae

Paroquet, Carolina

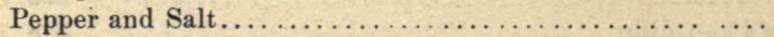

Phasmidae

Pigeons, Wild.

Pillar of the Constitution

Pitcher Plant

Plants in Winter

Plant Food

Porter's Cave

Pseudo-scorpion, Blind

Quarry, a Cave

Raccoon ............................... 105

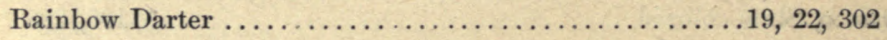

Rain-crow ................................ 86

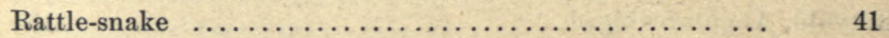

Banded .......................... 43

Prairie........................... 46

Rattle of ........................ 43,44

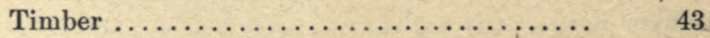

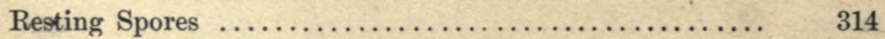

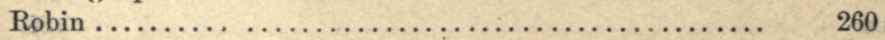

Rusts in Winter ............................. 314 
Salamander, Cave

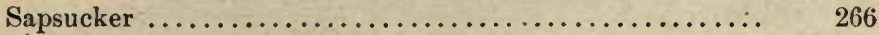

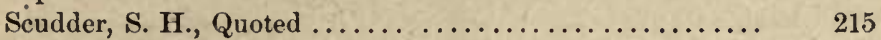

Seeds, Definition of ........................ 314

Dissemination of $\ldots \ldots \ldots \ldots \ldots \ldots \ldots \ldots \ldots, 249,291$

Shawnee Cave............................. 121

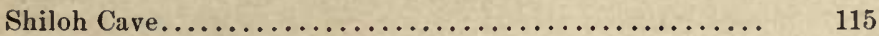

Shrike, Great Northern ..................... 287

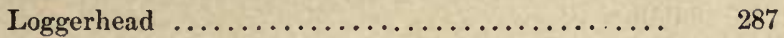

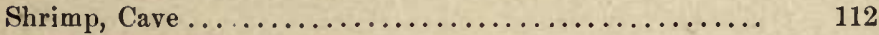

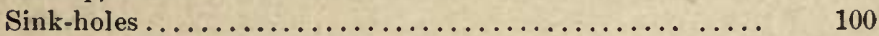

Formation of ..................... 101

Skunk Cabbage ............................ 13

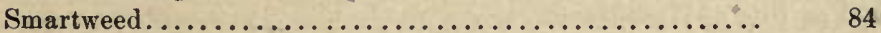

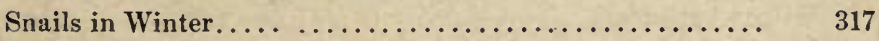

Snakes in General........................... 27

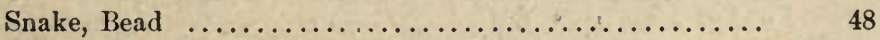

Black .....................28, 35, 37, 38, 53

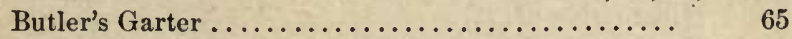

Chain ................................ 60

Copper-head ....................... 42

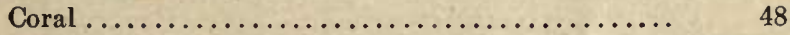

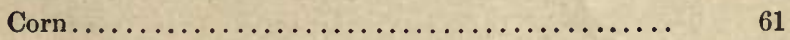

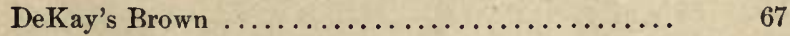

Diamond Water ........................ 51

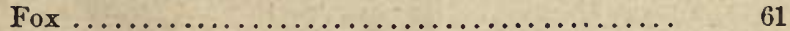

Garter............................ 33, 37, 63

"Glass" ......................... 27, 28

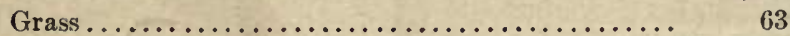

Green............................... 65, 67

Ground ............................... 69

Hog-nosed ........................... 71

"Hoop"

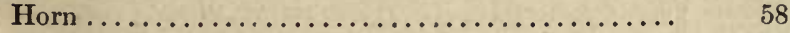

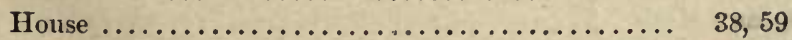

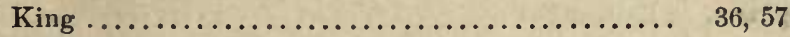

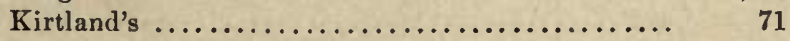

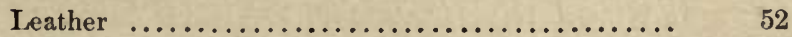

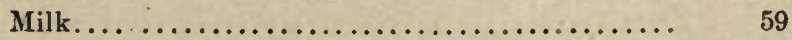


Snake, Pilot

PAGE.

Queen

38,55

Racine Garter ......................... 64

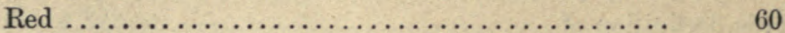

Ribbon $\ldots \ldots \ldots \ldots \ldots \ldots \ldots \ldots \ldots \ldots \ldots \ldots \ldots \ldots \ldots, \quad 62$

Ring-necked ........................... $\quad 70$

Spotted Water.......................... $\quad 50$

Storer's Brown........................ 68

Summer .......................... 35, 66

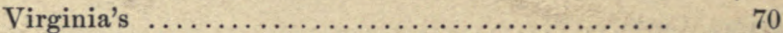

Water ............................. 35,49

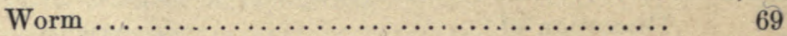

Snake Lies .............................. $\quad{ }_{27}$

Snakes, Bite of Harmless...................... $\quad 37$

Cannibalism of $\ldots \ldots \ldots \ldots \ldots \ldots \ldots \ldots \ldots \ldots \ldots \ldots \ldots, \quad 35$

Eggs of . . . .

Food of $\ldots \ldots \ldots \ldots \ldots \ldots \ldots \ldots \ldots \ldots \ldots \ldots \ldots \ldots \ldots, \quad 34$

Harmless ........................... 49

Hibernation of $\ldots \ldots \ldots \ldots \ldots \ldots \ldots \ldots \ldots \ldots \ldots \ldots \ldots \ldots \ldots, 330$

Methods of Defense of $\ldots \ldots \ldots \ldots \ldots \ldots \ldots \ldots . \quad 38$

Number of in Indiana................... $\quad 40$

Poisonous .............................. 40

Skeleton of $\ldots \ldots \ldots \ldots \ldots \ldots \ldots \ldots \ldots \ldots \ldots \ldots \ldots \ldots, \quad 31$

Skin of.............................. 31

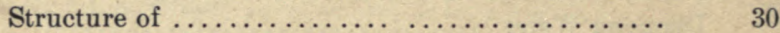

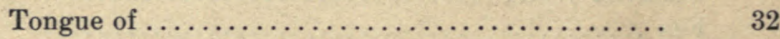

Young of ............................. 29, 30

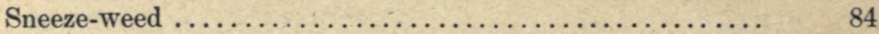

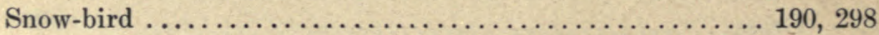

Snow Trillium . . . . . . . . 11

Sparrow Family ......................... 298, 303

Fox $\ldots \ldots \ldots \ldots \ldots \ldots \ldots \ldots \ldots \ldots \ldots, \quad 18$

Song $\ldots \ldots \ldots \ldots \ldots \ldots \ldots \ldots \ldots \ldots \ldots \ldots \ldots \ldots \ldots, \quad 190$

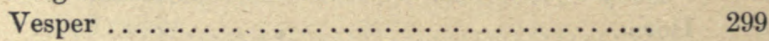

Sphinx Moth . . . . . . . 321

Spiders, as Balloonists ... . . . . . . . . . . . . . . . 193

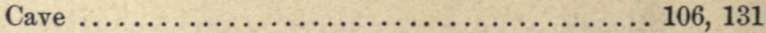

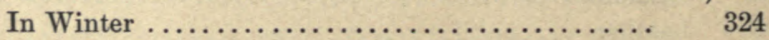

Nests.............................. 324 
Pagk.

Spring Beauty.......................... 14

Spring, Harbingers of $\ldots \ldots \ldots \ldots \ldots \ldots \ldots \ldots \ldots \ldots \ldots \ldots . \ldots \ldots$

Springtails, Cave .......................... 110

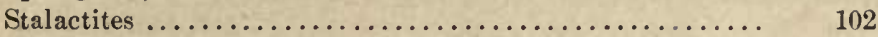

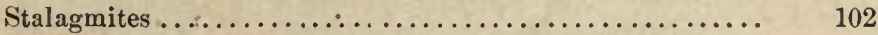

Struggle for Existence ......13, 22, 56, 79, 84, 88, 93, 116, 246, 283

Sun-fish, Long-eared....................... 22

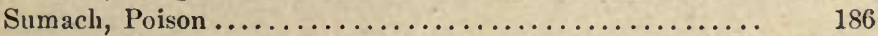

Swamp Elder ............................ 186

Sword-bearer .......................... 218

Tamarack Swamp, A Day in ................... 179

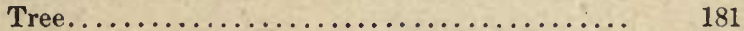

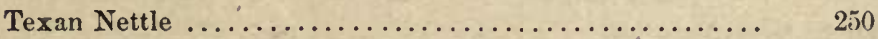

Thoreau, Quoted ....................... 18, 186, 330

Thrush, Brown.......................... 296

Titmouse, Tufted......................... 307

Trillium, Snow. ......................... 11-13

Trumpet Creeper ........................ 89

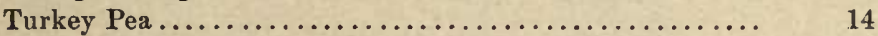

Turtles in Winter ......................... 330

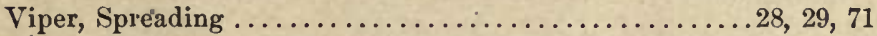

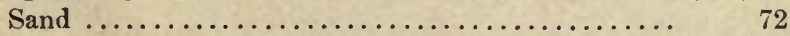

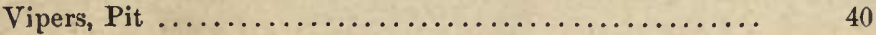

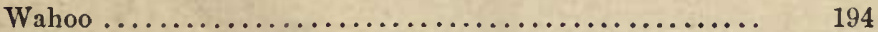

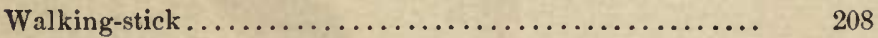

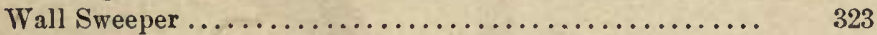

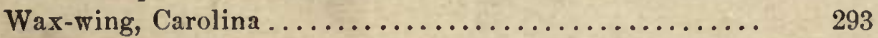

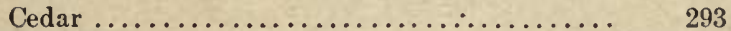

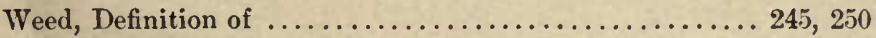

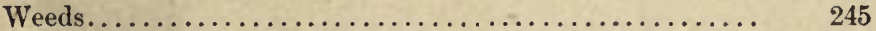

Twenty Worst in Indiaua ................ 251

Twenty Worst in United States .............. 246

Introduction of into United States ........... 248

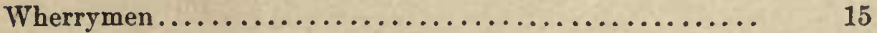

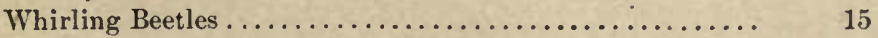

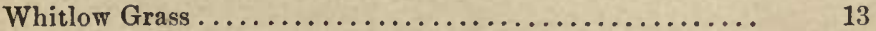


Winter Birds.

Woodpeckers, Adaptations of ......................

Benefits of.

Characters of

$258,263,267,273$

Woodpecker, Carolina

Downy. . 256

Hairy 262,265

Ivory-billed 262

Pileated 283

Red-bellied 284

Red-headed

256

Yellow-bellied ....................... 266

Wren, Great Carolina ........................ 275

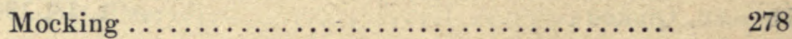

Winter. 194,280

Wyandotte Cave

Length of. 173

Little 175

Map of

Yellow-hammer 









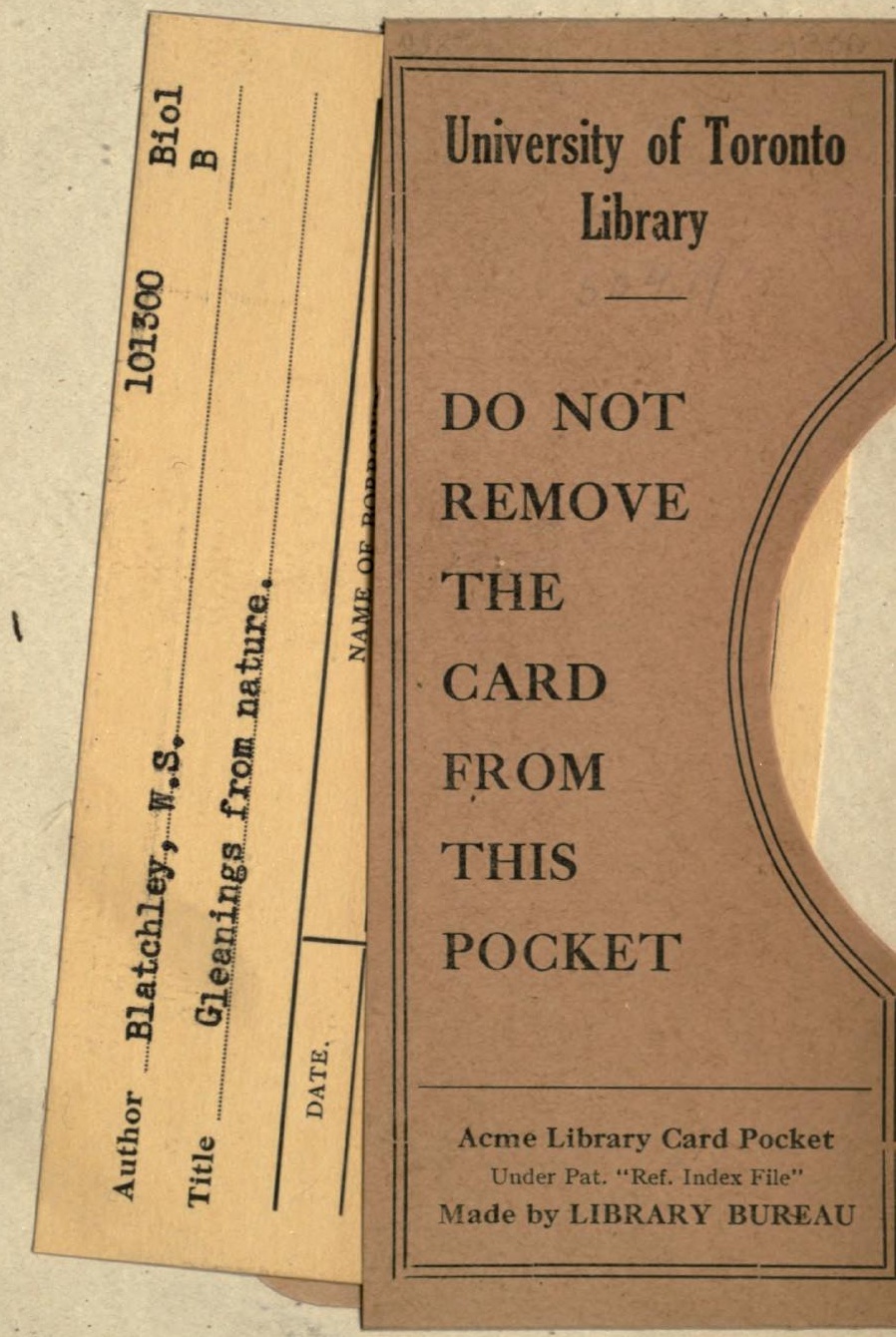


:

sing 